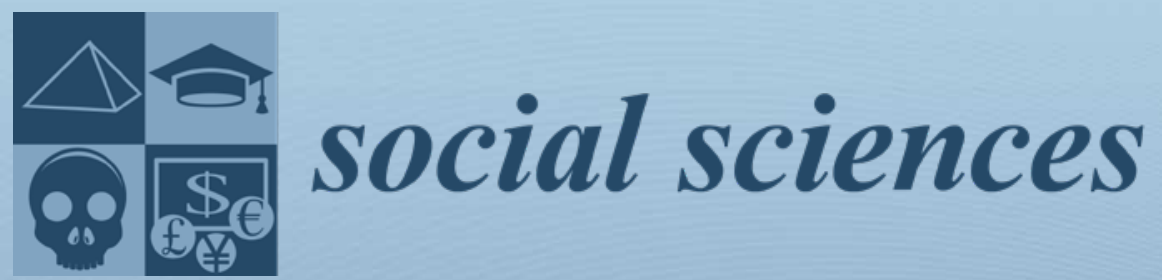

\title{
The End-Purpose of Teaching Social Sciences and the Curricular Inclusion of Social Problems
}




\section{The End-Purpose of Teaching Social Sciences and the Curricular Inclusion of Social Problems}





\section{The End-Purpose of Teaching Social Sciences and the Curricular Inclusion of Social Problems}

Editor

Delfín Ortega-Sánchez 
Editor

Delfín Ortega-Sánchez

Department of Specific Didactics

University of Burgos

Burgos

Spain

Editorial Office

MDPI

St. Alban-Anlage 66

4052 Basel, Switzerland

This is a reprint of articles from the Special Issue published online in the open access journal Social Sciences (ISSN 2076-0760) (available at: www.mdpi.com/journal/socsci/special_issues/ teaching_social_sciences).

For citation purposes, cite each article independently as indicated on the article page online and as indicated below:

LastName, A.A.; LastName, B.B.; LastName, C.C. Article Title. Journal Name Year, Volume Number, Page Range.

ISBN 978-3-0365-2887-8 (Hbk)

ISBN 978-3-0365-2886-1 (PDF)

(C) 2022 by the authors. Articles in this book are Open Access and distributed under the Creative Commons Attribution (CC BY) license, which allows users to download, copy and build upon published articles, as long as the author and publisher are properly credited, which ensures maximum dissemination and a wider impact of our publications.

The book as a whole is distributed by MDPI under the terms and conditions of the Creative Commons license CC BY-NC-ND. 


\section{Contents}

About the Editor $\ldots \ldots \ldots \ldots \ldots \ldots \ldots \ldots \ldots \ldots \ldots \ldots \ldots \ldots$

Preface to "The End-Purpose of Teaching Social Sciences and the Curricular Inclusion of

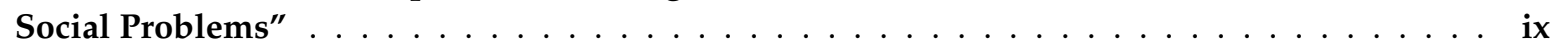

Delfín Ortega-Sánchez

The End-Purpose of Teaching Social Sciences and the Curricular Inclusion of Social Problems

Reprinted from: Soc. Sci. 2021, 11, 12, doi:10.3390/socsci11010012 _ . . . . . . . . . . . . . . 1

Delfín Ortega-Sánchez and Joan Pagès Blanch

The End-Purpose of Teaching History and the Curricular Inclusion of Social Problems from the Perspective of Primary Education Trainee Teachers

Reprinted from: Soc. Sci. 2020, 9, 9, doi:10.3390/socsci9020009 . . . . . . . . . . . . . . . . .

Jesús Marolla Gajardo, Jordi Castellví Mata and Rodrigo Mendonça dos Santos

Chilean Teacher Educators' Conceptions on the Absence of Women and Their History in Teacher

Training Programmes. A Collective Case Study

Reprinted from: Soc. Sci. 2021, 10, 106, doi:10.3390/socsci10030106 _ . . . . . . . . . . . . .

Jordi Castellví, María-Consuelo Díez-Bedmar and Antoni Santisteban

Pre-Service Teachers' Critical Digital Literacy Skills and Attitudes to Address Social Problems

Reprinted from: Soc. Sci. 2020, 9, 134, doi:10.3390/socsci9080134 . . . . . . . . . . . . . . . . .

Gustavo González-Valencia, María Ballbé and Delfín Ortega-Sánchez

Global Citizenship and Analysis of Social Facts: Results of a Study with Pre-Service Teachers

Reprinted from: Soc. Sci. 2020, 9, 65, doi:10.3390/socsci9050065 . . . . . . . . . . . . . . .

Roberto García-Morís, Nerea García Bugallo and Ramón Martínez-Medina

Students' Social Representations of Forced Migration as a Relevant Social Problem and Its Curricular Inclusion at the End of Primary School

Reprinted from: Soc. Sci. 2021, 10, 423, doi:10.3390/socsci10110423 _ . . . . . . . . . . . . 71

Marta Estellés, Francisco José Amo and Jesús Romero

The Consensus on Citizenship Education Purposes in Teacher Education

Reprinted from: Soc. Sci. 2021, 10, 164, doi:10.3390/socsci10050164 _ . . . . . . . . . . . . .

Nicolás De-Alba-Fernández, Elisa Navarro-Medina and Noelia Pérez-Rodríguez

School Inquiry in Secondary Education: The Experience of the Fiesta de la Historia Youth Congress in Seville

Reprinted from: Soc. Sci. 2021, 10, 165, doi:10.3390/socsci10050165 _ . . . . . . . . . . . . 107

José María Álvarez-Martínez-Iglesias, Pedro Miralles-Martínez, Jesús Molina-Saorín and Francisco Javier Trigueros-Cano

Secondary School Students' Perception of the Acquisition of Social Science Skill

Reprinted from: Soc. Sci. 2021, 10, 126, doi:10.3390/socsci10040126 . . . . . . . . . . . . . . 125

Efstratios Malliakas, Nelia Jiménez-Fanjul and Verónica Marín-Díaz

Educational Intervention through a Board Game for the Teaching of Mathematics to Dyslexic

Greek Students

Reprinted from: Soc. Sci. 2021, 10, 370, doi:10.3390/socsci10100370 



\section{About the Editor}

\section{Delfín Ortega-Sánchez}

Delfín Ortega-Sánchez holds a Ph.D. in Didactics of Social Sciences from the Autonomous University of Barcelona, a Ph.D. in Educational Sciences from the University of Burgos, and a Ph.D. in History from the University of Extremadura. His research interests focus on the construction of identities in the history and geography teaching, gender mainstreaming in initial education and training for teachers, the didactic treatment of relevant social problems and controversial issues in the teaching of the social and human sciences, and the application of educational technology in the specific field of social sciences. He is currently a social sciences teacher, researcher, and Vice-Rector for Social Responsibility, Culture, and Sports at the University of Burgos (Spain). 



\section{Preface to "The End-Purpose of Teaching Social Sciences and the Curricular Inclusion of Social Problems"}

Dedicated to Prof. Dr. Joan Pagès Blanch. With the publication of this monograph, written during 2020 and 2021, we pay our sincerest tribute to and gratitude for his teachings.

This Research Topic was completed with the main support of the Research Group Recognized in Didactics of History and Social Sciences (DHISO) (cod. 137), directed by Prof. Dr. Delfín Ortega-Sánchez (University of Burgos, Spain). Likewise, it has also been carried out within the framework of the projects Teach and learn to interpret contemporary problems and conflicts. What do social sciences contribute to the formation of a critical global citizenship? (EDU2016-80145-P), financed by the Ministry of Economy and Competitiveness (Spanish Government), and Future Education and Democratic Hope. Rethinking Social Studies Education in changing times (PID2019-107383RB-I00), financed by the Ministry of Science, and Innovation (Spanish Government).

Delfín Ortega-Sánchez

Editor 



\title{
Editorial \\ The End-Purpose of Teaching Social Sciences and the Curricular Inclusion of Social Problems
}

\author{
Delfín Ortega-Sánchez (D)
}

Citation: Ortega-Sánchez, Delfín. 2022. The End-Purpose of Teaching Social Sciences and the Curricular Inclusion of Social Problems. Social Sciences 11: 12. https://doi.org/ 10.3390/socsci11010012

Received: 26 December 2021 Accepted: 27 December 2021 Published: 29 December 2021

Publisher's Note: MDPI stays neutral with regard to jurisdictional claims in published maps and institutional affiliations.

Copyright: (C) 2021 by the author. Licensee MDPI, Basel, Switzerland. This article is an open access article distributed under the terms and conditions of the Creative Commons Attribution (CC BY) license (https:// creativecommons.org/licenses/by/ $4.0 /)$.
Department of Specific Didactics, Faculty of Education, University of Burgos, 09001 Burgos, Spain; dosanchez@ubu.es; Tel.: +34-947-111-832

\section{Aims and Scope}

The most recent scientific literature on the treatment of social problems or controversial social questions in the social sciences classroom and their inclusion into curricula emphasizes the need to introduce students into large-scale social debates where different points of view exist, different interests are at stake, and where it is desirable that they construct their own opinions in that respect from a critical and reasoned perspective. Research on social problems permits a typology of analysis that includes the relative experience of the past and the expectations for the future in a present that is lived and to consider the temporal relation on the basis of an analysis of changes and continuities that are observable from a comparative perspective. In the comprehension and interpretation of the historicity of the present and in planning the social future, social problems would have to represent a fundamental curricular tenant that gives relevance to the contemporaneousness of the student.

This Special Issue offers a rich collection of studies aimed at answering two structural research questions:

- What are the purposes of teaching history and social sciences at schools today?

- What is the place of social thought formation and social problems in learning/teaching in Social Sciences?

\section{Selected Studies}

A total of 13 studies were submitted, resulting from quantitative, qualitative, and mixed research designs. Finally, 9 passed the peer review process and consequently met the scientific quality standards required for its approval, subsequent publication, and inclusion in the Special Issue "The End-Purpose of Teaching Social Sciences and the Curricular Inclusion of Social Problems". The articles that make up this research topic have been written by renowned international specialists from Spain, Canada, and Chile in the field of social sciences didactics. Among them, special mention should be made of Dr. Joan Pagès (Autonomous University of Barcelona, Spain), Dr. Pedro Miralles (University of Murcia, Spain), and Dr. Antoni Santisteban (Autonomous University of Barcelona, Spain), leaders in this area of knowledge in the Ibero-American region.

The monograph opens with the article "The End-Purpose of Teaching History and the Curricular Inclusion of Social Problems from the Perspective of Primary Education Trainee Teachers" (Ortega-Sánchez and Blanch 2020). With a sample of 232 Spanish primary education trainee teachers, this study shows, among other results, an explanatory-predictive relationship between the variability of the degree of curricular relevance of social problems in primary education and the level of importance given by future teachers to its didactic treatment at this educational level. Likewise, this research provides qualitative evidence of the permanence of an instructional approach as the basic purpose of history teaching, to the detriment of others aimed at education for a democratic, global, equal, and inclusive citizenship from the assumption of human rights. As described in "Chilean Teacher Educators' Conceptions on the Absence of Women and Their History in Teacher Training 
Programmes. A Collective Case Study" (Marolla et al. 2021), this majority instructional approach seems to correspond equally with the permanence of patriarchal, hegemonic structures in the practices of history teachers, despite the existence of a teaching intention toward inclusion and social justice.

From this perspective, the research "Pre-Service Teachers' Critical Digital Literacy Skills and Attitudes to Address Social Problems" (Castellví et al. 2020) analyzes the difficulties of future primary school teachers $(n=322)$ in constructing critical discourses on certain social problems appearing in digital social media. These difficulties are confirmed in the research "Global Citizenship and Analysis of Social Facts: Results of a Study with Pre-Service Teachers" (González-Valencia et al. 2020), in which the distance of future secondary education teachers from conducting a true model of critical global citizenship education, based on the critical interpretation of social information with global implications, can be verified. On the contrary, the analysis of the social representations of primary education students $(n=70)$, "Students' Social Representations of Forced Migration as a Relevant Social Problem and Its Curricular Inclusion at the End of Primary School" (García-Morís et al. 2021), reports the predisposition of students in the last year of Spanish primary education to the curricular inclusion of social problems in the social studies education.

As argued in "The Consensus on Citizenship Education Purposes in Teacher Education" (Estellés et al. 2021), the difficulties and limitations of this priority purpose of social studies education are explained by the gap between the purposes of education for democratic citizenship and the reality of the social studies classroom. In this sense, "School Inquiry in Secondary Education: The Experience of the Fiesta de la Historia Youth Congress in Seville" (De-Alba-Fernández et al. 2021) analyzes the possibilities of including relevant social problems for the construction of global citizenship from the school. However, the results obtained continue to confirm the gap identified by Estellés et al. (2021), the disciplinary attachment, and the need to implement didactic proposals aimed at the teaching and learning of citizenship competencies.

Finally, with a large sample of students in the last year of Spanish secondary education $(n=1714)$, the research "Secondary School Students' Perception of the Acquisition of Social Science Skill" (Álvarez-Martínez-Iglesias et al. 2021) reveals the relational influence of assessment processes and the acquisition of competencies, key curricular elements in teaching social studies. Likewise, as evinced by "Educational Intervention through a Board Game for the Teaching of Mathematics to Dyslexic Greek Students" (Malliakas et al. 2021), this influence can be proven in the implementation of alternative teaching and learning interventions, and in obtaining positive effects and improvement of competency learning in students with dyslexia.

The relevant research results obtained in this Special Issue have been part of the International Seminar Integrated Teaching in Specific Didactics: Potentialities and Challenges of Transdisciplinary Integration for the Resolution of Contemporary Social Problems (2021), held between 8 and 12 November 2021. This event, organized by the Vice-Rectorate for Social Responsibility, Culture, and Sport of the University of Burgos, and by the Consolidated Research Unit 285-Didactics in STEAM areas (DAS) of the same institution, focused its interest on two interdependent lines of work:

(1) The epistemological reflection and analysis of the potentialities and challenges of integrated transdisciplinary teaching in specific didactics from social and scientificexperimental studies;

(2) The contribution of this integrated approach to the understanding, intervention, and resolution of contemporary social problems and to the Sustainable Development Goals of the 2030 Agenda, which is the specific theoretical and methodological development area of the present Special Issue. 


\section{Conclusions}

The core concept of education for citizenship is called active citizenship, understood as social participation based on mutual respect and non-violence, in accordance with human rights and democratic principles (Abs 2021). More than two decades have passed since the Council of Europe included, within the framework of the well-known Lisbon Strategy, the promotion of the concept of active citizenship and the learning of values and democratic participation as educational objectives.

To speak of education for citizen participation or for the exercise of active citizenship implies reflecting on how to teach in order to intervene, based on commitment and responsibility in issues-centered education, controversial issues, or socially acute questions. Despite the progress made, it is still necessary to design educational programs and practices specifically aimed at dealing with social problems and intervening in the community from an active citizenship approach.

The purpose of the teaching of social and human science disciplines must be directed toward education for an active, inclusive, and responsible democratic citizenship with the problems of its environment. Its natural contribution to education in democratic culture involves 10 key formative characteristics: (1) humanizing, (2) inclusive (gender), (3) based on otherness, (4) intercultural, (5) controversial (controversial issues), (6) aimed at the development of critical thinking skills, (7) based on peace, (8) sustainable, (9) aimed at the future, and (10) transformative. In this line, socio-scientific inquiry-based learning (SSIBL) could be of special didactic significance. The central idea of this methodology is the investigation of a problem that leads to the improvement of local and/or global conditions, producing actions through democratic processes and taking advantage of scientific knowledge, which can be re-contextualized as part of this process.

This essential purpose of social science education should keep its focus on intervention in community problems, assuming the notion of the problem as a connatural part of the very concept of democracy and the nature of social reality. There is no doubt that this intervention constitutes a basic element of education for the future and social action.

Funding: This research received no external funding.

Institutional Review Board Statement: Not applicable.

Informed Consent Statement: Not applicable.

Data Availability Statement: Not applicable.

Acknowledgments: This Special Issue was completed with the support of the Research Group Recognized in Didactics of History and Social Sciences (DHISO), and the Group for Educational Innovation in Didactics of Social Sciences, Languages, and Literatures in Initial Teacher Training of Early Childhood Education and Primary Education (DiCSOL) of the University of Burgos. This publication is part of the R\&D Project Teach and Learn to interpret contemporary problems and conflicts. What do the Social Sciences contribute to the formation of a critical global citizenship? (EDU2016-80145-P), financed by the Ministry of Economy and Competitiveness (Spanish Government), and Future Education and Democratic Hope. Rethinking Social Studies Education in changing times (PID2019-107383RBI00), financed by the Ministry of Science, and Innovation (Spanish Government).

Conflicts of Interest: The author declares no conflict of interest.

\section{References}

Abs, Hermann J. 2021. Options for developing European strategies on citizenship education. European Educational Research Journal 20: 329-47. [CrossRef]

Álvarez-Martínez-Iglesias, José María, Pedro Miralles-Martínez, Jesús Molina-Saorín, and Francisco Javier Trigueros-Cano. 2021. Secondary School Students' Perception of the Acquisition of Social Science Skill. Social Sciences 10: 126. [CrossRef]

Castellví, Jordi, María-Consuelo Díez-Bedmar, and Antoni Santisteban. 2020. Pre-Service Teachers' Critical Digital Literacy Skills and Attitudes to Address Social Problems. Social Sciences 9: 134. [CrossRef]

De-Alba-Fernández, Nicolás, Elisa Navarro-Medina, and Noelia Pérez-Rodríguez. 2021. School Inquiry in Secondary Education: The Experience of the Fiesta de la Historia Youth Congress in Seville. Social Sciences 10: 165. [CrossRef] 
Estellés, Marta, Francisco José Amo, and Jesús Romero. 2021. The Consensus on Citizenship Education Purposes in Teacher Education. Social Sciences 10: 164. [CrossRef]

García-Morís, Roberto, Nerea García, and Ramón Martínez-Medina. 2021. Students' Social Representations of Forced Migration as a Relevant Social Problem and Its Curricular Inclusion at the End of Primary School. Social Sciences 10: 423. [CrossRef]

González-Valencia, Gustavo, María Ballbé, and Delfín Ortega-Sánchez. 2020. Global Citizenship and Analysis of Social Facts: Results of a Study with Pre-Service Teachers. Social Sciences 9: 65. [CrossRef]

International Seminar Integrated Teaching in Specific Didactics: Potentialities and Challenges of Transdisciplinary Integration for the Resolution of Contemporary Social Problems. 2021. Available online: https://bit.ly/3szz1jY (accessed on 25 December 2021).

Malliakas, Efstratios, Noelia Jiménez-Fanjul, and Verónica Marín-Díaz. 2021. Educational Intervention through a Board Game for the Teaching of Mathematics to Dyslexic Greek Students. Social Sciences 10: 370. [CrossRef]

Marolla, Jesús, Jordi Castellví Mata, and Rodrigo Mendonça dos Santos. 2021. Chilean Teacher Educators' Conceptions on the Absence of Women and Their History in Teacher Training Programmes. A Collective Case Study. Social Sciences 10: 106. [CrossRef]

Ortega-Sánchez, Delfín, and Joan Pagès Blanch. 2020. The End-Purpose of Teaching History and the Curricular Inclusion of Social Problems from the Perspective of Primary Education Trainee Teachers. Social Sciences 9: 9. [CrossRef] 
Article

\title{
The End-Purpose of Teaching History and the Curricular Inclusion of Social Problems from the Perspective of Primary Education Trainee Teachers
}

\author{
Delfín Ortega-Sánchez ${ }^{1, *(1)}$ and Joan Pagès Blanch ${ }^{2}$ \\ 1 Department of Specific Didactics, Faculty of Education, University of Burgos, 09001 Burgos, Spain \\ 2 Department of Language, Literature and Social Science Education, Autonomous University of Barcelona, \\ 08193 Bellaterra (Cerdanyola del Vallès), Spain; joan.pages@uab.cat \\ * Correspondence: dosanchez@ubu.es; Tel.: +34-947-111-832
}

Received: 26 December 2019; Accepted: 21 January 2020; Published: 28 January 2020

check for updates

\begin{abstract}
The principal objective of the present study is to analyze the representations of Primary Education trainee teachers $(n=232)$ involving the end-purposes of teaching History and, in particular, their views on the didactic treatment and curricular inclusion of social problems at this educational stage. A mixed investigation method is applied, which combines both qualitative and quantitative approaches. The results pointed to a predictive influence of the degree of importance attached to the didactic treatment of social problems and the frequency with which they were covered on the Degree Course, for the assessment of their explicit inclusion in the Social Sciences curriculum. Likewise, the educational potential of the social problems appeared to be unconnected to the most highly assessed end-purposes, which are related to the development of social, critical, and creative thought for participation and social intervention.
\end{abstract}

Keywords: end-purposes of history teaching; relevant social problems; teacher training; Primary Education; social thought

\section{Introduction}

Reflecting on the end-purposes of teaching History and the Social Sciences allows teachers to guide decision-making, promote certain student models, and establish coherent connection links between their thinking and their own teaching practice. Teachers, as agents of social change, should reflect on what are the end-purposes of the Social Sciences that they impart in order to promote this coherence (Hernández 2013). Therefore, defining them during the university education of future teachers, and analyzing the results of its educational practice, constitutes indispensable knowledge for didactic change (Abellán 2014).

The end-purposes of teaching History and the Social Sciences would have to be directed towards critical comprehension of the reality and social democratic intervention. On that point, teacher training programs would be fruitless without the curricular incorporation of social problems (Benejam and Pagès 1997), which would offer the necessary results and instruments for decision-making and social commitment (Pagès 2002; González 2013). From this perspective, a training in social, critical, and creative thought, and education for the practice of democratic citizenship would have to constitute the fundamental foundation of the end-purposes of teaching the Social Sciences at school. Curricular inclusion of social problems yields precisely the right material for training in social thought, critical positioning, and student decision-making.

There is no doubt that education for democratic participation appears linked to training in social thought (Canal et al. 2012). This thought "is development when people are confronted with social 
problems, which are those that take up most of our lives, but are given little attention at school" (Pagès and Santisteban 2014, p. 26). Social and environmental problems are, in effect, the ones that have to be proposed as relevant educational objectives, in such a way that academic knowledge is placed at the service of their treatment and analysis (García-Pérez 2014), with the purpose of thinking through reality and developing the social and historical conscience of students.

The end-purpose of covering social problems in the teaching of Social Sciences therefore begins with the need to gain a critical understanding of reality in increasingly heterogenous societies (Kello 2016) of the inescapable educational promotion of social justice, and to learn and to teach active participation, in a committed and responsible way in the construction of responses and alternatives (Ten Dam and Volman 2004; Levstik and Tyson 2008; Pagès and Santisteban 2014). Education for social intervention and precise participation, in consequence, of the curricular incorporation and the didactic treatment of social problems and socially alive questions (Evans and Saxe 1996; Hess 2004; Legardez 2003; Santisteban 2012; Pagès and Santisteban 2011), and the acquisition of necessary professional competences for teaching in and for democratic citizenship (Martínez and Moreno 2012).

Indeed, international scientific literature has been demonstrating that the teaching of social problems and controversial issues constitutes one of the most powerful tools for the promotion of active citizenship, the development and acquisition of critical-reflexive thinking skills (Misco 2013), and education for democratic citizenship (Pollak et al. 2017; Misco and Lee 2014), which are the main purposes of teaching Social Sciences. It has also evidenced, however, the complexities, risks, and interferences of emotional reactions in the learning of sensitive, delicate, controversial or controversial historical, geographical, or social issues (Jerome and Elwick 2019; Reiss 2019; Ho and Seow 2015; Washington and Humphries 2011; Swalwell and Schweber 2016).

Recent studies have advanced in the analysis of the strategies used by teacher educators in the teaching of controversial subjects (Nganga et al. 2020; Pace 2019), and in the curricular decision making of teachers on this teaching (Hung 2019; King 2009). In these advances, the adequacy of the discussion or the development of deliberative skills and conversational learning is confirmed as the most appropriate strategy for the didactic treatment of social problems or controversial issues (Claire and Holden 2007; Oulton et al. 2004; Hand and Levinson 2012; Ezzedeen 2008). The promotion of the discussion on specific social justice problems has also been approached from the use of controversial images or documentary in teacher training contexts, in order to question what happens or has happened in present and past societies (Hawley et al. 2016; Marcus Alan S. 2009).

Thinking socially about reality and its teaching requires a conscious and reflective selection of social content, capable of allowing its problematization by teachers, and its reconstruction and critical treatment by students. This selection would transcend/apply potentially acquired knowledge from the most everyday contexts to the most remote and provide alternatives, or open exploration paths, to problems (creative thinking).

The predominance in Spain and other Latin-American countries of a History based on the national hegemonic narrative is so overwhelming that not even those who claim changes in teaching and teacher training have raised this debate and developed strategies so that history ceases to be led by the leading minorities and becomes open to the common people, to the others, to the different (Villalón and Pagès 2013). According to the research of Ortega-Sánchez (2019) for the Spanish context, a strong curricular standardization is evident in teaching practice, similar to that indicated by Misco (2013). This didactic positioning coincides with other studies such as Pollak et al. (2017), who demonstrate the resistance of teachers to complex and relativize curricular content through controversy. The treatment of social problems in teacher training appears to be linked to the development of social criticism, to the acquisition of social competences and to education for a democratic and participative culture (Santisteban 2012). The social problems, controversial topics, and socially alive questions are presented as indispensable elements for the integral development of civic and citizen-based competences (De Alba Fernández et al. 2012), through their relation with training in social thought (Pagès and Santisteban 2011, 2014). The conflict as a key concept for the selection and sequencing of 
social content in schools offers an excellent opportunity (Huddleston 2005; Santisteban 2015) for the acquisition of social and citizen-based competences transferable to any contemporary social problem, from the past or in the future (Ortega-Sánchez and Pagès 2017a).

The most recent scientific literature on the treatment of social problems or controversial social questions in the Social Sciences classroom and their curricular inclusion emphasizes the need to "introduce students into large-scale social debates where different points of view exist, different interests are at stake, and where it is desirable that they construct their own opinions in that respect from a critical and reasoned perspective" (Díaz and Fuente 2017, p. 26). In this sense, there are pioneering investigations such as those of Martínez and Pagès (2017) and Martínez (2017) on the design and the implementation of didactic sequences on the basis of songs for the didactic treatment of relevant social problems in basic secondary education. In accordance with the results obtained in these investigations, teaching actions should be oriented towards reflection on present problems, and towards methodological change are positive. Songs, included as socio-cultural sources on the problematization of content, are proposed as good resources for both teaching and learning relevant social problems and, in consequence, for training in social thought.

The absence of social problems in the curriculum and in editorial publications limits the approach of students both to integral knowledge of social contents and to its usefulness for the comprehension of the world, as well as limiting its possibilities for interpretation and responses to the complexity that characterizes it. Work with social problems "permits a typology of analysis that includes the relative experience of the past and the expectations for the future in a present that is lived, and to consider the temporal relation on the basis of the analysis of changes and continuities observable from a comparative perspective" (Grau 2016, p. 59). The didactic consideration of social problems as content and curricular strategy will, all in all, favor the development of social thought on social reality in the form of reflection and analysis (Segall and Gaudelli 2007), decision-taking, and the proposal of solutions (Pagès 2015; Santisteban 2009).

In the comprehension and interpretation of the historicity of the present and in planning the social future, social problems would have to represent a fundamental curricular tenant, giving relevance to the contemporaneousness of the student (Pagès 2007). We agree with Pagès and Santisteban (2014) in considering the need to prioritize investigation into historic-social thought, and reflection and proposals for solving social problems. However, investigation is still scarce on "the formation of creative, alternative and divergent thought, or on capacities to seek solutions to social problems" (Pagès and Santisteban 2014, p. 26).

The investigation evidences the advantages of studying social problems in teacher training and their impact on the representations of students. Ascertaining the social representations of trainee teachers on contemporary social problems, and the type of social thought that they experience, constitutes one of the first supports with which to define the criteria that have to guide the teaching of Social Sciences thought out to instill an understanding of social reality and intervention (Ortega-Sánchez and Pagès 2017a). Nevertheless, "not only should we make known the social problems that are relevant to our students, but the way we do so and the way the students contemplate their representations in the practice of teaching are fundamental" (Santisteban 2015, p. 390).

In this context, the principal objective of the present study consists of analyzing the representations of Primary Education Spanish trainee teachers on the end-purposes of teaching History and, in particular, the didactic treatment of social problems and their inclusion in the curriculum at that educational stage. Likewise, it seeks to confirm the existence of a predictive relation between the representations of the students on the degree of importance attached to the didactic treatment of social problems, and the frequency with which they are covered in their Degree courses, for the assessment of their explicit inclusion in the Social Sciences curriculum for Primary Education. Finally, the research seeks to note potential differences in the assessment of the curricular inclusion of social problems as a function of the sex and the age of the students. 
On the basis of these objectives, the study seeks to contribute to the training of critical Social Sciences teachers capable of articulating reflexive practices adopting active and committed positions (Bronckbank and McGill 2007; Perrenoud 2011) on relevant social problems and socially alive questions.

\section{Methods}

\subsection{Participants}

The sample was composed of a total of 232 students (women: $f=135 ; 58.2 \%$; men: $f=97 ; 41.8 \%$ ), enrolled on the fourth course of the Degree of Primary Education teacher at the University of Burgos, with an average age of 22.67 years $(S D=0.64$; range 21-22). Its frequency and percentage distribution by age groups was as follows: group $1=21-22(\mathrm{f}=99 ; 42.7 \%)$; group $2=23-24(\mathrm{f}=111 ; 47.8 \%)$; and group $3=25-26(f=22 ; 9.5 \%)$.

Intentional criteria guided the selection of the sample, in accordance with the adaptation of the characteristics of the participants to the set objectives of the investigation: having enrolled on the fourth year of the Degree in Primary Education Teaching at the University of Burgos; and having completed the first phase of teaching practice contemplated in the teaching plan of the Degree course.

\subsection{Instrument}

The ad hoc design of the instrument that was applied consisted of a questionnaire with fifteen items: eleven scalar items with a response interval of one to ten points, one scalar item of measurement (age), and two categorical nominal items of measurement (sex and curricular mention). With the object of triangulating the quantitative results, the instrument was completed by an open question included in the questionnaire "Contents, procedures, objectives, end-purposes, and protagonists of History teaching at school" (Ortega-Sánchez 2017) (Table 1).

Table 1. EpHT Questionnaire and scale. Source: Authors.

\begin{tabular}{|c|c|}
\hline \multicolumn{2}{|r|}{ EpHT Questionnaire and Scale } \\
\hline \multicolumn{2}{|r|}{ Sociodemographic characteristics } \\
\hline \multicolumn{2}{|r|}{ 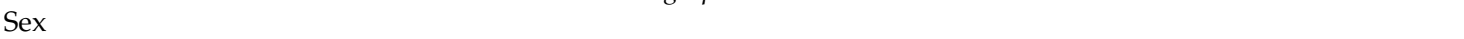 } \\
\hline \multicolumn{2}{|c|}{ Age } \\
\hline \multicolumn{2}{|r|}{ Degree course } \\
\hline c.1 & Values the frequency with which current social problems have been covered on the Degree course. \\
\hline c. 2 & The social problems have to be explicitly included in the curricular area of Primary Education Social Sciences. \\
\hline c. 3 & $\begin{array}{l}\text { What level of importance do you attach to the didactic treatment of social problems in Primary Education? } \\
\text { EpHT (End-purposes of History teaching) }\end{array}$ \\
\hline c. $4-1$ & Help students to construct their own view of people and things (critical capacities of social analysis). \\
\hline c. $4-2$ & Awaken and develop (critical and creative) social thought in children. \\
\hline c. $4-3$ & Educate for social intervention and transformation in a process of continuous improvement of democratic life. \\
\hline c. $4-4$ & $\begin{array}{l}\text { Encourage learning, from a critical and reflexive point of view with the capacity for social comprehension } \\
\text { and analysis. }\end{array}$ \\
\hline c. $4-5$ & $\begin{array}{l}\text { Educate for the practice of democratic socialization, training students so that they can and wish to participate } \\
\text { in the problems of social reality. }\end{array}$ \\
\hline c. $4-6$ & Socialize students for their adaptation to the society in which they live. \\
\hline c. $4-7$ & Know the past for the construction of national identities (History as magistra vitae). \\
\hline c. $4-8$ & $\begin{array}{l}\text { Obey the rules and norms established by the society in which the students live. } \\
\text { Open question }\end{array}$ \\
\hline c.5 & $\begin{array}{l}\text { According to your criteria and the training on the Degree Course, what social end-purpose and what } \\
\text { objectives would have to be selected for the teaching of History in Primary Education at school? Give } \\
\text { your reasons? }\end{array}$ \\
\hline
\end{tabular}

The preparation of the EpHT scale began with the review of the scientific literature and, in particular, the works of Pagès (1994, 2002), Santisteban (2012), Ortega-Sánchez (2017), Abellán (2014), González (2013), and Hernández (2013).

Both Cronbach's $\alpha$ and the coefficient of composite reliability and internal consistency, $\omega$, were determined, to check the reliability and internal consistency of the scale, and assuming the circumstance of normality and consistency of the data. The indices yielded satisfactory results $(\alpha=0.917 ; \omega=0.967)$. 
In a first phase, an exploratory Principal Components Analysis (PCA) with varimax rotation was performed, in order to test the validity of the construct and the goodness of fit of the data. The type of factorial rotation in use applied the Kaiser rule to eigenvalues greater than 1 . This model permits the identification of correlative levels or theoretical relations between the variables that have been established, to reduce their number and to summarize the data in view of the objective under study.

With a view to understanding the factorization possibilities of the matrix, and prior to the analysis, we examined the matrix of correlations/covariables between variables, by applying Bartlett's test of sphericity, and the Kaiser, Meyer Olkin measurement index of sampling adequacy. The results obtained in the KMO test $(0.797)$ and in the sphericity test $\left(\chi^{2}{ }_{(28)}=4057.975 ; p=0.000\right)$ indicated the adequacy of the matrix to be factorized. The exploratory factor analysis identified two factors that explained $94.94 \%$ of the total variance. Values below 0.40 were used for the validation of the scale (Table 2).

Table 2. Rotated component matrix for the EpHT.

\begin{tabular}{|c|c|c|c|}
\hline & \multirow{2}{*}{ End-Purposes of History Teaching (EpHT) } & \multicolumn{2}{|c|}{ Component } \\
\hline & & 1 & 2 \\
\hline c. $4-1$ & $\begin{array}{l}\text { Help students to construct their own view of people and things (critical capacity for } \\
\text { social analysis) }\end{array}$ & 0.960 & \\
\hline c. $4-2$ & Awaken and develop (critical and creative) social thought of the child & 0.958 & \\
\hline c. $4-3$ & $\begin{array}{l}\text { Educate for social intervention and transformation in a continuous process of } \\
\text { improvement of democratic life }\end{array}$ & 0.956 & \\
\hline c. $4-4$ & $\begin{array}{l}\text { From a critical and reflexive point of view, promote learning of capabilities and } \\
\text { understanding of social analysis }\end{array}$ & 0.942 & \\
\hline c. $4-5$ & $\begin{array}{l}\text { Educate for the practice of democratic socialization, training students so that they can } \\
\text { and wish to participate in the problems of social reality }\end{array}$ & 0.910 & \\
\hline c. $4-6$ & Socialize students for their adaptation to the society in which they live & & 0.979 \\
\hline c. $4-7$ & Know the past (History as magistra vitae) & & 0.964 \\
\hline c. $4-8$ & Obey the rules and the norms established by the society in which the student lives & & 0.958 \\
\hline
\end{tabular}

In accordance with these results, in a second phase, we completed a confirmatory factor analysis. Having linked two errors of observation in factor 2, the goodness of fit values were acceptable for the following indices: NFI (=0.931), IFI (=0.935) and CFI (=0.935) (Figure 1$)$.

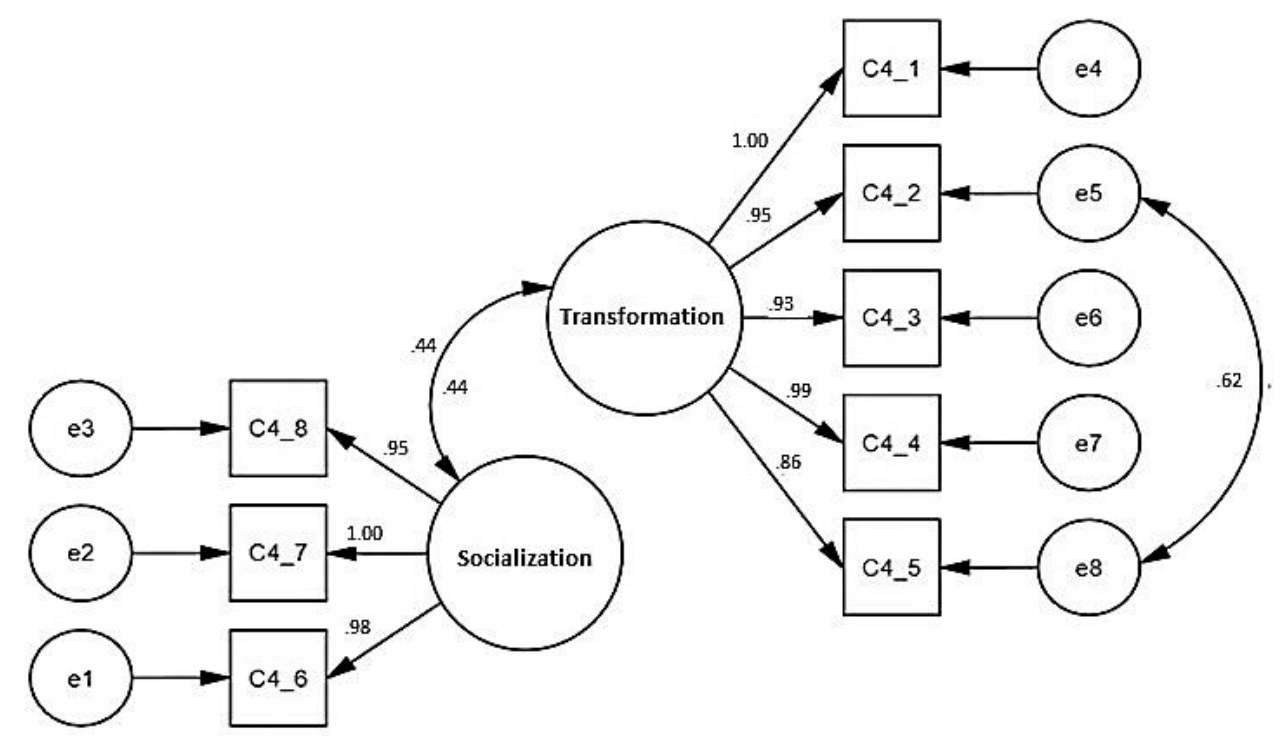

Figure 1. Latent, observed, and residual variables, and correlations of the EpHT scale.

The results uphold the dimensional correspondence of the instrument designed with the two factors from both analyses:

1. Socialization (three items): The items linked with this dimension point to end-purposes in the teaching of Social Sciences oriented towards socialization, integration, and adaptation of the social 
environment to the students. Educational opportunities are not needed for active participation and social commitment towards relevant social problems or socially alive questions in the social reality of the students. It corresponds to a technical conception of the Social Sciences curriculum (Pagès 1994), in which a definite curricular model is explained, and to the maintenance of its status quo for education in good citizenship.

2. Social transformation (five items): The items linked with this dimension are oriented towards education for democratic citizenship, on the basis of the development of critical capacity for social analysis, (critical and creative) social thought, critical reflection and social participation in social reality. This dimension corresponds to a critical conceptualization of the Social Sciences curriculum. Its approach begins with constructivist principles and the development of critical thought, and considers the relevance of the analysis of the social problems of Humanity and daily life today. It values the ideological nature of the curriculum and teaching practice, problematizing the contents, and facilitating their construction and learning among students. From this approach "the complexity of the problems and explanatory concepts constitutes one of the principal articulations of teaching both for learning what is known and what is unknown" (Pagès 1994, p. 42).

\subsection{Design and Procedure}

A mixed investigation method that combined both qualitative and quantitative approaches was selected, employing different types of questions, techniques, and compilation, and data analysis procedures (Creswell and Plano 2007; Teddlie and Tashakkori 2009). The investigation subscribes, on the one hand, to quantitative methodological principles and to transversal ex-post facto non-experimental designs (Hernández et al. 2010). On the other hand, it is positioned among the interpretative qualitative designs through the application of content-analysis techniques, the definition of aprioristic categories (Cisterna 2005), based on the questions and the objectives of the present investigation, and the case study, the interest of which lies in the capability and depth of explanation of specific contexts (Cohen and Manion 2002).

A questionnaire was completed that was applied during the first week of the start of the study unit Investigation and Innovation in the learning of Environmental Studies (academic years 2015/2016, 2016/2017 and 2017/2018), an obligatory study unit in the fourth year specifically programmed from a critical-emancipatory curricular approach towards the teaching of History and the Social Sciences (Abellán 2014; Pagès 1994).

After the explanation of the purpose of the investigation, participants were reminded of the data privacy laws and the anonymous way in which the quantitative and qualitative data would be processed and interpreted. The qualitative information was faithfully transcribed by the investigators in the way it was expressed, avoiding any textual or discursive correction.

\subsection{Data Analysis}

Having confirmed the normal distribution of the variables of the instrument with the Kolmogorov-Smirnov ( $p \geq 0.73$ ) test, we completed a descriptive analysis (averages and SD) of the total data obtained and an inferential analysis (contingency tables, Pearson correlations, the student $t$-test for independent samples, single-factor ANOVA for independent groups and post hoc analysis ), with the object of confirming the existence of statistically significant differences in the scores, as a function of sex and the age groups, given the need to include social problems in the Social Sciences curriculum (dependent variable c.2). Following the atypical distribution of this variable, a logarithmic transformation was performed that reached the necessary assumed level of normality $(p=0.89)$. Likewise, this variable was also re-coded at three levels, in order to generate the contingency tables, in accordance with the scores that the students gave them: negative curricular necessity (1.00-4.99); low-positive curricular necessity (5.00-5.99); medium-curricular necessity (6.00-7.99); high-positive curricular necessity (8.00-8.99); and very-high-positive curricular necessity (9.00-10.00). 
Finally, having confirmed the positive correlation between variables c.1-c.2 and c.3-c.2, we completed a multiple linear regression to test the influence and the magnitude of the two independent variables in the explanation of variable c.2. Likewise, we calculated the size effect of both variables on the dependent variable through a covariance analysis (ANCOVA). We used the statistical package SPSS v.24 for the treatment and analysis of the quantitative data.

The qualitative information in question c.5 was initially subjected to a careful exploratory-comparative reading of the available content, with both the object of reducing the units of analysis to significant registry units and to identify the thematic lines and the possibilities for saturation of the established aprioristic categories (Rodríguez et al. 2005): a positivist and technical, humanist and practical, and emancipatory perspective (Abellán 2014). This categorization system makes an acceptable contribution to the analysis of didactic sequences and programs and their orientation, to the observation and analysis of teaching practice, and to the promotion of critical, autonomous, and committed attitudes. Subsequently, on the basis of constant data comparisons, a deductive process of codification was conducted by which the contents were assigned to one of the three categories central to the analysis.

The students, their qualifications, their age-groups, and academic courses were all identified alphanumerically, for the identification of the participants, the organization of the registry units, and the presentation of the qualitative results: $E_{x}-T_{\text {group }}$ [student (identification number)-qualification $_{\text {([group]-academic course) }}$ ].

ATLA.ti software (v. 7.5.4) was used for the analysis of the qualitative data, because of its capacity for encoding, categorization, informative saturation, and interpretation of the information that was obtained.

\section{Results}

\subsection{Quantitative Descriptive Study}

Situated in a medium range (6.00-7.99), the students evaluated the frequency with which social problems were discussed on their Degree course, with a score of $7.1(S D=1.20)$. Likewise, the score given to 'necessity to include social problems in the Social Science curriculum' is also situated on this parameter in the area of Primary Education Social Sciences $(M=6.7 ; S D=1.16)$ and the importance of its didactic treatment at this educational stage $(M=6.9 ; S D=1.74)$ (Table 3$)$.

Table 3. EpHT Scale. Descriptive statistics by variable. ( $\mathrm{M}=\mathrm{Mean}$ and $\mathrm{SD}=$ Standard Deviation).

\begin{tabular}{cccc}
\hline Variable & $\mathbf{N}$ & $\mathbf{M}$ & $\mathbf{S D}$ \\
\hline c.1 & 232 & 7.1 & 1.20 \\
c. & 232 & 6.7 & 1.16 \\
c.3 & 232 & 6.9 & 1.74 \\
c.4-1 & 232 & 7.5 & 1.30 \\
c.4-2 & 232 & 8.1 & 0.63 \\
c.4-3 & 232 & 8.1 & 0.59 \\
c.4-4 & 232 & 9.0 & 0.51 \\
c.4-5 & 232 & 8.1 & 0.69 \\
c.4-6 & 232 & 7.4 & 1.04 \\
c.4-7 & 232 & 7.3 & 1.03 \\
c.4-8 & 232 & 7.2 & 1.06 \\
\hline
\end{tabular}

With regard to the EpHT scale and the scores given, the trainee teachers considered that 'promoting learning, from a critical and reflexive point of view, of comprehension capacities and social analysis' constituted the principal end-purpose of teaching Social Sciences in Primary Education $(M=9.0$; $S D=0.51$ ), followed by 'awaken and develop the (critical and creative) social thought of the child" $(M=8.1 ; S D=0.63)$; 'educate for social intervention and transformation in a continuous process of improvement of democratic life' $(M=8.1 ; S D=0.59)$; and 'educate for the practice of democratic 
socialization, training the students so that they can and wish to participate in the problems of social reality' $(M=8.1 ; S D=0.69)$. The other remaining end-purposes that were proposed received scores in a medium range of 7.2 and 7.5 .

\subsection{Inferential Quantitative Study}

Having confirmed the homogeneity of the variances of the groups through the Levene statistic, the results informed us of statistically significant differences between the scores given to the necessity of incorporating social problems in the curriculum of Social Sciences as a function of $\operatorname{sex}\left(t_{(230)}=-2.431\right.$; $p=0.016)$, and the non-existence of significant differences between the age groups of the students $\left(\mathrm{F}_{(2,229)}=2.813 ; p=0.062\right)$, a circumstance confirmed in the results of the post hoc Schefee analysis (Table 4).

Table 4. Comparison of averages between groups-age.

\begin{tabular}{|c|c|c|c|c|c|c|}
\hline \multirow{2}{*}{ I } & \multirow{2}{*}{$\mathbf{J}$} & \multirow{2}{*}{ I-J } & \multirow{2}{*}{ Std. Error } & \multirow{2}{*}{ Sig. } & \multicolumn{2}{|c|}{ Interval of Confidence at $95 \%$} \\
\hline & & & & & Lower Limit & Upper Limit \\
\hline \multirow{2}{*}{1} & 2 & -0.210 & 0.102 & 0.121 & -0.46 & 0.04 \\
\hline & 3 & 0.081 & 0.173 & 0.897 & -0.35 & 0.51 \\
\hline \multirow{2}{*}{2} & 1 & 0.210 & 0.102 & 0.121 & -0.04 & 0.46 \\
\hline & 3 & 0.291 & 0.172 & 0.240 & -0.13 & 0.71 \\
\hline \multirow{2}{*}{3} & 1 & -0.081 & 0.173 & 0.897 & -0.51 & 0.35 \\
\hline & 2 & -0.291 & 0.172 & 0.240 & -0.71 & 0.13 \\
\hline
\end{tabular}

As may be seen, $30.6 \%$ of the sample scored at very low levels (Table 5). At that level, the majority were men who gave the lowest scores to the necessity of including social problems in the Social Sciences curriculum. A majority of both men and women scored at medium levels (men = 48.5\%; women =52.6\%). Nevertheless, women fundamentally gave high scores with $21.5 \%$ (high positive necessity).

Table 5. Contingency table for the two variables Curricular inclusion of social problems (c.2) and Sex.

\begin{tabular}{|c|c|c|c|c|c|}
\hline & & & \multicolumn{2}{|c|}{ Sex } & \multirow{2}{*}{ Total } \\
\hline & & & Men & Women & \\
\hline \multirow{8}{*}{$\begin{array}{l}\text { Curricular inclusion } \\
\text { of social problems }\end{array}$} & Low-positive necessity & f. & 38 & 33 & 71 \\
\hline & $(5.00-5.90)$ & $\%$ & $39.2 \%$ & $24.4 \%$ & $30.6 \%$ \\
\hline & Medium-positive necessity & f. & 47 & 71 & 118 \\
\hline & $(6.00-7.90)$ & $\%$ & $48.5 \%$ & $52.6 \%$ & $50.9 \%$ \\
\hline & High-positive necessity & f. & 9 & 29 & 38 \\
\hline & $(8.00-8.99)$ & $\%$ & $9.3 \%$ & $21.5 \%$ & $16.4 \%$ \\
\hline & Very high-positive necessity & f. & 3 & 2 & 5 \\
\hline & $(9.00-10.00)$ & $\%$ & $3.1 \%$ & $1.5 \%$ & $2.2 \%$ \\
\hline \multirow{2}{*}{\multicolumn{2}{|c|}{ Total }} & f. & 97 & 135 & 232 \\
\hline & & $\%$ & $100.0 \%$ & $100.0 \%$ & $100.0 \%$ \\
\hline
\end{tabular}

The scores by age groups are specified in Table 6 . It is notable that $50.9 \%$ of the total sample was concentrated around medium scores on the 'Curricular inclusion of social problems', all of them situated in the majority age group of the whole sample (group $2=22-23$ years; $f=66,59.5 \%$ ). 30.6\% were distributed between groups 1 (21-22 years) and 2, while group 1 had the highest frequencies in low-positive scores $(\mathrm{f}=38)$ as opposed to group $2(\mathrm{f}=24)$. 
Table 6. Contingency table for the variables Curricular inclusion of social problems (c.2) and Age groups.

\begin{tabular}{|c|c|c|c|c|c|c|}
\hline & & & \multicolumn{3}{|c|}{ Age Groups } & \multirow{2}{*}{ Total } \\
\hline & & & 1 & 2 & 3 & \\
\hline \multirow{8}{*}{$\begin{array}{l}\text { Curricular } \\
\text { inclusion of social } \\
\text { problems }\end{array}$} & Low-positive necessity & f. & 38 & 24 & 9 & 71 \\
\hline & $(5.00-5.90)$ & $\%$ & $38.4 \%$ & $21.6 \%$ & $40.9 \%$ & $30.6 \%$ \\
\hline & \multirow{2}{*}{$\begin{array}{l}\text { Medium-positive necessity } \\
\quad(6.00-7.90)\end{array}$} & f. & 42 & 66 & 10 & 118 \\
\hline & & $\%$ & $42.4 \%$ & $59.5 \%$ & $45.5 \%$ & $50.9 \%$ \\
\hline & \multirow{2}{*}{$\begin{array}{l}\text { High-positive necessity } \\
(8.00-8.99)\end{array}$} & f. & 19 & 16 & 3 & 38 \\
\hline & & $\%$ & $19.2 \%$ & $14.4 \%$ & $13.6 \%$ & $16.4 \%$ \\
\hline & \multirow{2}{*}{$\begin{array}{l}\text { Very high-positive necessity } \\
\qquad(9.00-10.00)\end{array}$} & f. & 0 & 5 & 0 & 5 \\
\hline & & $\%$ & $0.0 \%$ & $4.5 \%$ & $0.0 \%$ & $2.2 \%$ \\
\hline & \multirow{2}{*}{ Total } & f. & 99 & 111 & 22 & 232 \\
\hline & & $\%$ & $100.0 \%$ & $100.0 \%$ & $100.0 \%$ & $100.0 \%$ \\
\hline
\end{tabular}

The remaining scores were distributed between the high and very high levels, especially highlighting the frequencies of groups 1 and 2, with a level of representativeness of $18.6 \%$ of the total sample.

Having confirmed the existence of a high and a moderate correlation between 'The importance of covering social problems' and 'Curricular integration' $(r=0.811 ; p=0.000)$, and the frequency of their treatment on the Degree course and their curricular integration $(r=0.556 ; p=0.000)$, we tested the causal goodness of the model and obtained satisfactory values $\left(\mathrm{F}_{(2.229)}=242.922 ; p=0.000\right)$. It is evident that the independent variables c. 1 and c.3 yielded an optimum value for the variance of c.2 of $68 \%\left(R^{2}=0.680\right)$.

The levels of linear dependence, intensity, and the relation effect confirmed that both the variable c. $1(t=3.922 ; p=0.000 ; \beta=0.173)$ and the variable c. $3(t=16.267 ; p=0.000 ; \beta=0.719)$ jointly revealed a statistically significant effect and therefore influenced the explanation of the assessments given by the students to the necessity for the curricular inclusion of social problems. This circumstance is confirmed when assessing the analysis as control variables, sex, and age, considering that they could affect the study of the dependent variable (Table 7).

Table 7. Correlation coefficients and size effect for the variables c. 1 and c. 3 on the dependent variable c.2.

\begin{tabular}{lcccccc}
\hline & $\mathbf{r}$ & $\boldsymbol{P}$ & $\mathbf{t}$ & $\boldsymbol{P}$ & $\boldsymbol{\beta}$ & $\boldsymbol{\eta}^{\mathbf{2}} \mathbf{p}$ \\
\hline c.1. Frequency & 0.556 & $0.000^{* *}$ & 3.922 & 0.000 & 0.173 & 0.063 \\
c.3. Importance & 0.811 & $0.000^{* *}$ & 16.267 & 0.000 & 0.719 & 0.536 \\
c.1. Frequency. CV (sex*age) & & & 3.382 & 0.001 & 0.147 & \\
c.3. Importance. CV (sex*age) & & & 14.068 & 0.000 & 0.687 & \\
\hline
\end{tabular}

** $p<0.01$ (bilateral). CV = control variable.

It may therefore be confirmed that the greater the recognition of the necessity to include social problems in the Social Sciences curriculum, the greater the perceptions on the frequency with which it was covered on the Degree Course and the assessment of its importance. Likewise, we confirmed that the independent variable that had the most influence on the assessments given to the dependent variable was the importance attributed to the didactic treatment of social problems in Primary Education $(\beta=0.719)$. Equally, this variable recorded a significant effect size on the dependent variable $\left(\eta^{2} p=0.536\right)$. As a consequence, the variability of the degree of curricular pertinence of social problems is fundamentally explained by the level of importance given to the didactic treatment of social problems in Primary Education. 


\subsection{Qualitative Study}

The responses given to the open question c.5 ('According to your opinion and Degree Course, what social end-purpose and objectives would have to be covered in the teaching of History in Primary Education?') were explained from two or three established aprioristic categories (positivist and technical perspectives, as well as critical and emancipatory perspectives), without obtaining adequate definitions for the humanist and practical category. Exactly $48 \%$ of the responses attributed an instructive social function, in the current social panorama, to the teaching of History at school.

The end-purposes of teaching and learning History linked with this category are directed at offering a representation of the past as an explanatory axis of current political realities, which is, History at school as magistra vitae in the management of contemporary societies. From this perspective, the teaching and learning of History is oriented towards the acquisition of objective historical and social knowledge, neutral and universalist, the identification of the principal ideas of historical and social discourses, and the preparation of an "enunciative, descriptive, and schematic discourse" (Abellán 2014, p. 104). History that is taught in the scientific field is articulated around reproductive mechanisms of the curricular regulations and the fundamental figures and processes for the construction of the national identity. Likewise, this approach is founded on the recognition of the existence of a single past, explaining a common cultural inheritance:

Knowing the historic past, analyzing historic events to learn about the success and not to repeat mistakes $\left(\mathrm{E}_{34}\right.$-Primary $\left.4[1]-15 / 16\right)$

The main end-purpose would be to know world history with its great conflicts thinking about the reasons and the consequences, in such a way that, when you know your history, you're not condemned to repeat it $\left(\mathrm{E}_{25}\right.$-Primaria $\left.4[2]-15 / 16\right)$

Those contents that are picked up with the intention of social progress [which] we are capable of reflecting upon so as not to repeat the mistakes of the past $\left(\mathrm{E}_{78}\right.$-Primary $\left.{ }_{4[2]-16 / 17}\right)$

The end-purpose of History is to understand the present through knowledge of past events and their evolution. This will avoid committing the same mistakes in the future [ . . ] $\left(\mathrm{E}_{152}\right.$-Primary $\left.{ }_{4[3]-16 / 17}\right)$

The social end-purpose and the most important objective is that the students always know how to improve as people, taking as an example what has happened in the past ( $\mathrm{E}_{181}$-Primary $\left.4[1]-17 / 18\right)$

Sensitivity to children with the education of 21st century and guidance to improve that education taking into account all the mistakes made in History $\left(\mathrm{E}_{203}\right.$-Primary $\left.4[1]-17 / 18\right)$

Along these lines, there are significant affirmations (32\%) in support of a scholarly History, understood in terms of traditional chronological, political, and hegemonic parameters. In these responses, the selection of content and the formulation of objectives is dependent on technical-reproductive proposals oriented towards "knowing the facts that have meant we are who we are" (E96-Primary4[2]-16/17):

The primary objective would be that students know the passage of the different economic and political historical events until passing on to the current ones, and that they understand and properly construct the historical contents of the curriculum of the study unit ( $\mathrm{E}_{65}$-Primary $\left.4[1]-15 / 16\right)$

Students must understand the events that have marked the History of our past and its societies, so that they can understand current history and behave as good citizens ( $\mathrm{E}_{44}$-Primary $\left.4[2]-15 / 16\right)$

Explain where we came from (characteristics, stages ... ). Recognize differences between stages. Study regional communities, provinces, capitals, rivers ... of Spain. Describe political, economic, social, and cultural characteristics of Spain ( $\mathrm{E}_{121}$-Primary $\left.{ }_{4[2]-16 / 17}\right)$ 
Know the most important facts of History, above all, in Spain, and the stages through which we have passed throughout our time ( $\mathrm{E}_{198}$-Primaria 4 -[3]17/18)

From among the responses, $20 \%$ of the students also supported the social function and the objectives of History teaching in education for democratic, global, egalitarian, and inclusive citizenship, which begins with the assumption of Human Rights. A social function that, the students point out, guarantees the "training in critical thought [ ... ]" (E $E_{75}-$ Primaria $\left._{4[1]-15 / 16}\right)$, and the development and acquisition of "[ ... ] social and civic responsibility before the problems of the present" (E83-Primary4[2]-16/17).

In the critical and emancipatory category, education for the democratic exercise of a plural and diverse citizenship is defined as one of the principal end-purposes of teaching and learning History. Through this approach, the aim is "create a willingness in the student, so that, through critical comprehension of the present reality, the student will wish to think and to intervene in the construction of the future" (Abellán 2014, p. 105). Democratic values and the development of historic thought, empathy, imagination, and historic creativity have to be useful to approach social problems, and to apply social and historic knowledge to the proposals for the resolution of social problems.

To construct your identity as a citizen from various perspectives: the individual, the collective, and globally, in order to conduct ourselves properly in the diversity of the current world, respecting the rest and knowing that we also should be respected ( $\mathrm{E}_{13}$-Primary4[1]-15/16)

To train active citizens with a commitment towards an inclusive society. To train critical people capable of relating what happened before with what is happening now and not only learn it without any discussion ( $\mathrm{E}_{5}$-Primary4[2]-15/16)

Education directed towards the edification of democratic and free people, with social, human, and civic values. People who respect rights and obligations, as well as the identities of the other; people who respect and tolerate plurality and globality. In addition, History teaching should be based on developing the capabilities of students, in order to [... ] understand geographic, sociological, and historic aspects and, by doing so, they can interpret the reality in which they live and they can intervene in it (E90-Primary $4[2]-16 / 17)$

Education for citizenship with critical thought, knowledge of Human Rights and of social problems, so that solutions may be put forward ( $\mathrm{E}_{142}$-Primary4[1]-16/17)

To develop the critical capability [of the student] and to promote an active consciousness. To promote an inclusive democratic society, where no differentiations exist between classes and where the whole world has the same rights and opportunities, whether men or women ( $\mathrm{E}_{170}$-Primary4[2]-17/18)

To prepare the student as an active citizen in society, educating for democratic and inclusive citizenship, in which Human Rights are respected, as well as having a critical capacity [for the analysis] of social events ( $\mathrm{E}_{169}$-Primary4[3]-17/18)

\section{Discussion and Conclusions}

While the students highlighted the development and learning of comprehensive and analytical skills and the analysis of social reality as among the most prominent end-purposes in the teaching of the Social Sciences, students also attached average scores to the importance of the didactic treatment of social problems and the need to include them in the Primary Education curriculum. Likewise, these results informed us of statistically significant differences between the scores as a function of sex. According to the studies by Ortega-Sánchez $(2017,2019)$ and Ortega-Sánchez and Pagès (2018), one of the possible interpretations of this difference can be found in the explicit female recognition of gender inequalities as a social problem and in the identification of the invisibility of women in the traditional historical narrative. Their educational potential appeared to be unconnected to the most highly valued end-purpose: the development of social, critical, and creative thought. In contrast, the research of 
Souto (2015) on the attitudes and the competences of Primary Education teachers and Geography and History teachers states that, in their majority, trainee teachers selected the affirmation that "the teacher must have, above all, an attitude of knowing the great social problems of the contemporary world so that they are the object of scholarly analysis" (p. 41), and the capability "to select social and environmental problems that will be studied in the educational contents". These affirmations can also be found in the research of Byford et al. (2009) on the attitudes of teachers towards the teaching of controversial questions in the classroom. Likewise, the studies on the recent standardized evaluations of the Organic Law for the Improvement of Educational Quality (LOMCE) confirm the possibilities of the students giving mature explanations, on the basis of evaluative designs that consider capabilities for solving social problems (Souto et al. 2014).

The results of the open question, however, point toward the need for History teaching at school as magistra vitae, one of the end-purposes with the lowest scores EpHT $(M=7.3 ; S D=1.03)$. In fact, $80 \%$ of students adopted the position of a positivist-technical curricular approach towards the teaching of History, as against the $20 \%$ that adopted a critical-emancipatory approach. This last approach to the teaching of History is directed towards education for good citizenship that helps students move towards the critical analysis of information (Ross 2004) and to follow the construction of social knowledge from its unfinished structure. Nevertheless, this proposed approach appears not to be having a real impact in practice (Vázquez 2014), in that the social problems could make the management of social reality possible. Along these lines, the investigation of Harris and Clarke (2011) was developed on the challenge of approaching cultural diversity and ethnicity in the British History curriculum and, more recently, the study by Woolley (2017), in which the need to promote the diversity of interpretations and the presence of multiple perspectives is affirmed in response to the teaching of controversial and polemical topics in the history classroom.

The results obtained in the present investigation reaffirm those obtained in the investigation of Abellán (2014), where the dependence on school textbooks is noted, and the persistence of representations on the meaning of teaching and learning linked to a technical curricular model. Likewise, the conclusions reached in the investigation by Canals (2015) in teacher training contexts consider that "the quality of social thought that students construct, when they present their points of view talking of current social problems related with the contents of the study unit, is quite poor" (Canals 2015, p. 452).

In this sense, the investigation by Castellví (2018) on the construction of stories about relevant local social problems among Primary Education students from the final phases affirmed their difficulties over constructing stories on relevant social topics in a coherent, reflective, and critical way. Teacher training from the principles of critical literacy could be the impetus for action, social commitment, and intervention in social problems, and the development of democratic consciousness (Ortega-Sánchez and Pagès 2017b).

Likewise, the assessment of the degree of importance of the didactic treatment of social problems and socially alive questions during Primary Education, in a predictive and prominent way, influence their explicit integration in the Social Sciences curriculum. These results coincide with those obtained in the investigation of Ortega-Sánchez and Pagès (2016). Along those lines, the investigation of De Alba and Navarro (2017) on education in History and good citizenship among students completing their Bachiller studies shows the need to consider the curriculum as a dynamic construction, which is necessarily adapted to social change. The strengthening of democratic learning would therefore move on to "organizing the curriculum through socially relevant problems" (p. 93). A need was also found in the investigation by González and Sant (2014), where the affirmation of both active and trainee-teachers was noted of the importance of working content linked to socially relevant problems of good citizenship.

The reproduction of traditional curricular approaches in teaching practices hides the daily social problems that confront participative citizenship. The end-purpose of teaching History and Social Sciences has therefore to lead to perspectives based on controversial topics, relevant social problems, and 
socially alive questions, which are at the foundation of our daily life and that sustain the development of social and citizenship-based competences (Éthier and Lefrançois 2008; Heimberg 2010; Hess 2004; Pagès and Santisteban 2011).

Author Contributions: Conceptualization, D.O.-S. and J.P.B.; methodology, D.O.-S.; software, D.O.-S.; validation, D.O.-S.; formal analysis, D.O.-S.; investigation, D.O.-S. and J.P.B.; resources, D.O.-S. and J.P.B.; data curation, D.O.-S. and J.P.B.; writing — original draft preparation, D.O.-S. and J.P.B.; writing - review and editing, D.O.-S. and J.P.B.; supervision, J.P.B. All authors have read and agreed to the published version of the manuscript.

Funding: This research received no external funding.

Acknowledgments: The study was approved by the research project EDU2016-80145-P (Ministry of Economy and Business of Spain), and by the Research Group of the University of Burgos of Didactics of History and Social Sciences (DHISO).

Conflicts of Interest: The authors declare no conflict of interest.

\section{References}

Abellán, Jordi. 2014. La reflexión sobre las finalidades de la enseñanza de la Historia. Un estudio de caso en la formación inicial del profesorado en el sistema educativo mexicano. Doctoral thesis, Universitat Autònoma de Barcelona, Bellaterra, Spain. Available online: https://ddd.uab.cat/record/132348?ln=ca (accessed on 13 April 2019).

Benejam, Pilar, and Joan Pagès. 1997. Enseñar y aprender Ciencias Sociales. Geografía e Historia en la Educación Secundaria. Barcelona: Institut de Ciències de l'Educació/Universitat de Barcelona/Horsori.

Bronckbank, Anne, and Ian McGill. 2007. Facilitating Reflective Learning in Higher Education. Berkshire and New York: Open University Press-McGraw-Hill.

Byford, Jeff B., Sean Lennon, and William B. Russell. 2009. Teaching Controversial Issues in the Social Studies: A Research Study of High School Teachers. The Clearing House: A Journal of Educational Strategies 82: 165-70. [CrossRef]

Canal, Marta, Daniel Costa, and Antoni Santisteban. 2012. El alumnado ante problemas sociales relevantes: ¿Cómo los interpreta? ¿Cómo piensa la participación? In Educar para la participación ciudadana en la enseñanza de las Ciencias Sociales. Edited by Nicolás de Alba, Francisco. F. García-Pérez and Antoni Santisteban. Seville: AUPDCS-Díada Editora, vol. 1, pp. 527-35.

Canals, Roser. 2015. El desarrollo del pensamiento social en la formación inicial del profesorado para dar respuesta a problemas sociales invisibles desde el currículo. In Una enseñanza de las Ciencias Sociales para el futuro: Recursos para trabajar la invisibilidad de personas, lugares y temáticas. Edited by Ana María Hernández, Carmen R. García and Juan L. de la Montaña. Cáceres: University of Extremadura-AUPDCS, pp. 447-56.

Castellví, Jordi. 2018. La construcción de relatos sobre problemas sociales relevantes locales de alumnos de ciclo superior de Primaria en la era digital. In Buscando formas de enseñar: Investigar para innovar en Didáctica de las Ciencias Sociales. Edited by Esther López, Carmen R. García and María Sánchez. Valladolid: Universidad de Valladolid-AUPDCS, pp. 965-74.

Cisterna, Francisco. 2005. Categorización y triangulación como procesos de validación del conocimiento en investigación cualitativa. Theoria 14: 61-71.

Claire, Hilary, and Cathie Holden. 2007. The Challenge of Teaching Controversial Issues. Trentham Books: Stoke on Trent.

Cohen, Louis, and Lawrence Manion. 2002. Métodos de investigación educativa. Madrid: La Muralla.

Creswell, John. W., and Vicki L. Plano. 2007. Designing and Conducting Mixed Methods Research. Thousand Oaks: SAGE Publications.

De Alba, Nicolás, and Elisa Navarro. 2017. La educación para la ciudadanía a través de la enseñanza de la Historia: Estrategias de mejora para el centro, el docente y el currículum. Giornale Italiano della Ricerca Educativa-Italian Journal of Educational Research, 89-98.

De Alba Fernández, Nicolás, Francisco F. García-Pérez, and Antoni Santisteban, eds. 2012. Educar para la participación ciudadana en la enseñanza de las Ciencias Sociales. Seville: AUPDCS-Díada.

Díaz, Naira, and María del Mar de la Fuente. 2017. Problemas sociales relevantes en el aula de primaria: La "cartografía de la controversia" como método. REIDICS. Revista de Investigación en Didáctica de las Ciencias Sociales 1: 24-38. 
Éthier, Marc-André, and David Lefrançois. 2008. Investigación sobre el desarrollo de competencias en ciencias sociales a partir de prácticas políticas y comunitarias. Íber. Didáctica de las Ciencias Sociales, Geografía e Historia 58: 89-107.

Evans, Ronald W., and David W. Saxe, eds. 1996. Handbook on Teaching Social Issues. Washington, DC: NCSS.

Ezzedeen, Souha R. 2008. Facilitating Class Discussions around Current and Controversial Issues: Ten Recommendations for Teachers. College Teaching 56: 230-36. [CrossRef]

García-Pérez, Francisco F. 2014. Ciudadanía participativa y trabajo en torno a problemas sociales y ambientales. In Una mirada al pasado y un proyecto de futuro. Investigación e Innovación en Didáctica de las Ciencias Sociales. Edited by Joan Pagès and Antoni Santisteban. Barcelona: Universitat Autònoma de Barcelona-AUPDCS, vol. 1, pp. 119-25.

González, Gustavo A. 2013. El profesorado en formación y las finalidades de la enseñanza de las Ciencias Sociales. Unipluri/versidad 13: 24-34.

González, Gustavo A., and Edda Sant. 2014. ¿Que debe saber el profesorado para educar a ciudadanos críticos y participativos? In Una mirada al pasado y un proyecto de futuro. Investigación e Innovación en Didáctica de las Ciencias Sociales. Edited by Joan Pagès and Antoni Santisteban. Barcelona: Universitat Autònoma de Barcelona-AUPDCS, vol. 2, pp. 295-304.

Grau, Víctor. 2016. El valor de la alteridad: Enseñanza-aprendizaje a partir de realidades problemáticas temporales. In Deconstruir la alteridad desde la Didáctica de las Ciencias Sociales: educar para una ciudadanía global. Edited by Carmen R. García, Aurora Arroyo and Beatriz Andreu. Las Palmas: Universidad de Las Palmas de Gran Canaria-AUPDCS, pp. 58-66.

Hand, Michael, and Ralph Levinson. 2012. Discussing Controversial Issues in the Classroom. Educational Philosophy and Theory 44: 614-29. [CrossRef]

Harris, Richard, and Gill Clarke. 2011. Embracing diversity in the history curriculum: A study of the challenges facing trainee teachers. Cambridge Journal of Education 41: 159-75. [CrossRef]

Hawley, Todd S., Alicia R. Crowe, and Evan Mooney. 2016. Visualizing Social Justice: Using Controversial Images in Social Studies Classrooms. The Clearing House: A Journal of Educational Strategies, Issues and Ideas 89: 85-90. [CrossRef]

Heimberg, Charles. 2010. ¿Cómo puede orientarse la educación para la ciudadanía hacia la libertad, la responsabilidad y la capacidad de discernimiento de las nuevas generaciones? Íber: Didáctica de las Ciencias Sociales, Geografía e Historia 64: 48-57.

Hernández, Lorenia. 2013. La enseñanza de las Ciencias Sociales en la formación profesional de las estudiantes de maestra de Educación Infantil. Doctoral thesis, Universitat Autònoma de Barcelona, Bellaterra, Spain. Available online: https://ddd.uab.cat/record/115328?ln=ca (accessed on 25 August 2019).

Hernández, Roberto, Carlos Fernández, and María del Pilar Baptista. 2010. Metodología de la investigación. México: McGraw-Hill.

Hess, Diana E. 2004. Controversies about controversial issues in democratic education. PS: Political Science $\mathcal{E}$ Politics 37 2: 257-61.

Ho, Li-Ching, and Tricia Seow. 2015. Teaching Controversial Issues in Geography: Climate Change Education in Singaporean Schools. Theory \& Research in Social Education 43: 314-44.

Huddleston, T. 2005. Teacher training in citizenship education: Training for a new subject or for a new kind of subject? Journal of Social Science Education 4: 50-63.

Hung, Yu-Han. 2019. To teach or not teach controversial public issues in Taiwan? Asia Pacific Journal of Education 39: 562-76. [CrossRef]

Jerome, Lee, and Alex Elwick. 2019. Teaching about terrorism, extremism and radicalisation: Some implications for controversial issues pedagogy. Oxford Review of Education 1-16. [CrossRef]

Kello, Katrin. 2016. Sensitive and controversial issues in the classroom: Teaching history in a divided society. Teachers and Teaching 22: 35-53. [CrossRef]

King, John T. 2009. Teaching and Learning about Controversial Issues: Lessons from Northern Ireland. Theory $\mathcal{E}$ Research in Social Education 37: 215-46.

Legardez, Alain. 2003. L'enseignement des questions sociales et historiques, socialement vives. Le Cartable de Clio 3: $245-53$.

Levstik, Linda S., and Cynthia A. Tyson, eds. 2008. Handbook of Research in Social Studies Education. New York and London: Routledge. 
Marcus Alan S., Jeremy D. Stoddard. 2009. The Inconvenient Truth about Teaching History with Documentary Film: Strategies for Presenting Multiple Perspectives and Teaching Controversial Issues. The Social Studies 100: 279-84. [CrossRef]

Martínez, Iván A. 2017. ¡Profe, enséñame con canciones! Una investigación sobre el uso de las canciones en la enseñanza y aprendizaje de las Ciencias Sociales. Doctoral Thesis, Universitat Autònoma de Barcelona, Bellaterra, Spain. Available online: https://ddd.uab.cat/record/187750?ln=ca (accessed on 5 June 2019).

Martínez, María Dolores Jiménez, and Concepción Moreno. 2012. Formar para enseñar en participación ciudadana. Una experiencia integradora. In Educar para la participación ciudadana en la enseñanza de las Ciencias Sociales. Edited by Nicolás de Alba, Francisco F. García-Pérez and Antoni Santisteban. Seville: AUPDCS-Díada Editora, vol. 2, pp. 511-19.

Martínez, Iván A., and Joan Pagès. 2017. Aprender Historia y Ciencias Sociales utilizando las canciones. Resultados de una investigación. Clío \& Asociados. La historia enseñada 24: 83-99.

Misco, Thomas. 2013. 'We do not talk about these things': The promises and challenges of reflective thinking and controversial issue discussions in a Chinese high school. Intercultural Education 24: 401-16. [CrossRef]

Misco, Thomas, and Lena Lee. 2014. "There is no such thing as being Guamanian": Controversial Issues in the Context of Guam. Theory \& Research in Social Education 42: 414-39.

Nganga, Lydiah, Amy Roberts, John Kambutu, and Joanie James. 2020. Examining pre-service teachers' preparedness and perceptions about teaching controversial issues in social studies. The Journal of Social Studies Research 44: 77-90. [CrossRef]

Ortega-Sánchez, D. 2017. Las mujeres en la enseñanza de la Historia y de las Ciencias Sociales: estudio de caso en formación inicial de maestros y maestras de Educación Primaria. Doctoral thesis, Universitat Autònoma de Barcelona, Bellaterra, Spain. Available online: https://ddd.uab.cat/record/187752 (accessed on 15 October 2019).

Ortega-Sánchez, Delfín. 2019. Teaching Gender in the History Classroom: An Investigation into the Initial Training of Primary Education Teachers. Education Sciences 9: 114. [CrossRef]

Ortega-Sánchez, Delfín, and Joan Pagès. 2016. Deconstruyendo la alteridad femenina en la enseñanza de la Historia escolar: representaciones sociales del profesorado de educación primaria en formación. In Deconstruir la alteridad desde la Didáctica de las Ciencias Sociales: Educar para una ciudadanía global. Edited by Carmen R. García, Aurora Arroyo and Beatriz Andreu. Las Palmas: Universidad de Las Palmas de Gran Canaria-AUPDCS, pp. 184-93.

Ortega-Sánchez, Delfín, and Joan Pagès. 2017a. Las representaciones sociales de los problemas contemporáneos en estudiantes de Magisterio de Educación Primaria. Investigación en la Escuela. Revista internacional de investigación e innovación educativa 93: 1-16. [CrossRef]

Ortega-Sánchez, Delfín, and Joan Pagès. 2017b. Literacidad crítica, invisibilidad social y género en la formación del profesorado de Educación Primaria. REIDICS. Revista de Investigación en Didáctica de las Ciencias Sociales 1: 102-17.

Ortega-Sánchez, Delfín, and Joan Pagès. 2018. La construcción de identidades de género en la enseñanza de la Historia escolar: Un estudio a partir de las narrativas históricas de los futuros y futuras docentes en Educación Primaria. In Buscando formas de enseñar: Investigar para innovar en Didáctica de las Ciencias Sociales. Edited by Esther López, Carmen R. García and María Sánchez. Valladolid: Universidad de Valladolid-AUPDCS, pp. 89-100.

Oulton, Christopher, Vanessa Day, Justin Dillon, and Marcus Grace. 2004. Controversial issues-Teachers' attitudes and practices in the context of citizenship education. Oxford Review of Education 30: 489-507. [CrossRef]

Pace, Judith L. 2019. Contained risk-taking: Preparing preservice teachers to teach controversial issues in three countries. Theory \& Research in Social Education 47: 228-60.

Pagès, Joan. 1994. La Didáctica de las Ciencias Sociales, el currículum de historia y la formación del profesorado. Signos. Teoría y práctica de la educación 13: 38-51.

Pagès, Joan. 2002. Aprender a enseñar Historia y Ciencias Sociales: El currículo y la Didáctica de las Ciencias Sociales. Pensamiento Educativo 30: 255-69.

Pagès, Joan. 2007. La enseñanza de las ciencias sociales y la educación para la ciudadanía en España. Didáctica geográfica 9: 205-14.

Pagès, Joan. 2015. La educación política y la enseñanza de la actualidad en una sociedad democrática. Educaçâo em Foco 19: 17-37. 
Pagès, Joan, and Antoni Santisteban. 2011. Les qüestions socialment vives i l'ensenyament de les Ciències Socials. Barcelona: Universitat Autònoma de Barcelona.

Pagès, Joan, and Antoni Santisteban. 2014. Una mirada del pasado al futuro en la Didáctica de las Ciencias Sociales. In Una mirada al pasado y un proyecto de futuro. Investigación e Innovación en Didáctica de las Ciencias Sociales. Edited by Joan Pagès and Antoni Santisteban. Barcelona: Universitat Autònoma de Barcelona-AUPDCS, vol. 1, pp. 17-39.

Perrenoud, Philippe. 2011. Desarrollar la práctica reflexiva en el oficio de enseñar. Barcelona: Graó.

Pollak, Italy, Aliza Segal, Adam Lefstein, and Assaf Meshulam. 2017. Teaching controversial issues in a fragile democracy: Defusing deliberation in Israeli primary classrooms. Journal of Curriculum Studies 50: 387-409. [CrossRef]

Reiss, Michael J. 2019. Evolution education: Treating evolution as a sensitive rather than a controversial issue. Ethics and Education 14: 351-66. [CrossRef]

Rodríguez, Clemente, Oswaldo Lorenzo, and Lucía Herrera. 2005. Teoría y práctica del análisis de datos cualitativos. Proceso general y criterios de calidad. Revista Internacional de Ciencias Sociales y Humanidades 15: 133-54.

Ross, E. Wayne. 2004. Social Studies and Critical Thinking. Kincheloe. In Critical Thinking and Learning: An Encyclopedia for Parents and Teachers. Edited by Danny K. Weil and Joe L. Kincheloe. Westport: Greenwood Publishing Group, pp. 383-88.

Santisteban, Antoni. 2009. Cómo trabajar en clase la competencia social y ciudadana. Aula de Innovación Educativa 187: 12-15.

Santisteban, Antoni. 2012. La investigación sobre el desarrollo de la competencia social y ciudadana para una participación crítica. In Educar para la participación ciudadana en la enseñanza de las Ciencias Sociales. Edited by Nicolás de Alba, Francisco F. García-Pérez and Antoni Santisteban. Seville: AUPDCS-Díada Editora, vol. 1, pp. 277-86.

Santisteban, Antoni. 2015. La formación del profesorado para hacer visible lo invisible. In Una enseñanza de las Ciencias Sociales para el futuro: Recursos para trabajar la invisibilidad de personas, lugares y temáticas. Edited by Ana María Hernández, Carmen R. García and Juan L. de la Montaña. Cáceres: University of Extremadura-AUPDCS, pp. 383-93.

Segall, Avner, and William Gaudelli. 2007. Reflecting Socially on Social Issues in a Social Studies Methods Course. Teaching Education 18: 77-92. [CrossRef]

Souto, Xosé M. 2015. Hacemos visible la hipocresía social en las actividades escolares. In Una enseñanza de las Ciencias Sociales para el futuro: Recursos para trabajar la invisibilidad de personas, lugares y temáticas. Edited by Ana María Hernández, Carmen R. García and Juan L. de la Montaña. Cáceres: University of Extremadura-AUPDCS, pp. 23-48.

Souto, Xosé. M., Carlos Fuster, and Jorge Sáiz. 2014. Un camino de ida y vuelta: Revalidas y selectividad en las rutinas escolares de la enseñanza de la Geografía e Historia. In Una mirada al pasado y un proyecto de futuro. Investigación e Innovación en Didáctica de las Ciencias Sociales. Edited by Joan Pagès and Antoni Santisteban. Barcelona: Universitat Autònoma de Barcelona-AUPDCS, vol. 2, pp. 157-66.

Swalwell, Katy, and Simone Schweber. 2016. Teaching through Turmoil: Social Studies Teachers and Local Controversial Current Events. Theory \& Research in Social Education 44: 283-315.

Teddlie, Charles, and Abbas Tashakkori. 2009. Foundations of Mixed Methods Research: Integrating Quantitative and Qualitative Approaches in the Social and Behavioral Sciences. Thousand Oaks: SAGE Publications.

Ten Dam, Greet, and Monique Volman. 2004. Critical thinking as a citizenship competence: Teaching strategies. Learning and Instruction 14: 359-79. [CrossRef]

Vázquez, Felicia. 2014. El pensamiento docente en relación a la Historia en un contexto de enseñanza situada. In Una mirada al pasado y un proyecto de futuro. Investigación e Innovación en Didáctica de las Ciencias Sociales. Edited by Joan Pagès and Antoni Santisteban. Barcelona: Universitat Autònoma de Barcelona-AUPDCS, vol. 2, pp. 651-58.

Villalón, Gabriel, and Joan Pagès. 2013. ¿Quién protagoniza y cómo la historia escolar? La enseñanza de la historia de los otros y las otras en los textos de estudio de Historia de Chile de educación primaria. Clío \& Asociados. La historia enseñada 17: 119-36. 
Washington, Elizabeth Yeager, and Emma K. Humphries. 2011. A Social Studies Teacher's Sense Making of Controversial Issues Discussions of Race in a Predominantly White, Rural High School Classroom. Theory $\mathcal{E}$ Research in Social Education 39: 92-114.

Woolley, Mary C. 2017. The attitudes and perceptions of beginning teachers in relation to teaching controversial issues in the history classroom. Revista Electrónica Interuniversitaria de Formación del Profesorado 20: 1-16. Available online: http://revistas.um.es/reifop/article/view/284561 (accessed on 10 June 2019). [CrossRef]

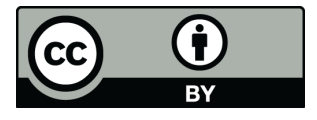

(C) 2020 by the authors. Licensee MDPI, Basel, Switzerland. This article is an open access article distributed under the terms and conditions of the Creative Commons Attribution (CC BY) license (http://creativecommons.org/licenses/by/4.0/). 



\title{
Chilean Teacher Educators' Conceptions on the Absence of Women and Their History in Teacher Training Programmes. A Collective Case Study
}

\author{
Jesús Marolla Gajardo ${ }^{1, * \mathbb{D}}$, Jordi Castellví Mata ${ }^{2} \mathbb{D}$ and Rodrigo Mendonça dos Santos ${ }^{3}$ (D) \\ 1 Faculty of Education, University of The Americas, Santiago de Chile 8370040, Chile \\ 2 Faculty of Education, International University of La Rioja, 26006 La Rioja, Spain; Jordi.Castellvimata@unir.net \\ 3 Department of Curriculum \& Pedagogy, Faculty of Education, University of British Columbia, \\ Vancouver, BC V6T 1Z4, Canada; rodrigo.santos@ubc.ca \\ * Correspondence: jmarolla@udla.cl
}

check for

updates

Citation: Marolla Gajardo, Jesús, Jordi Castellví Mata, and Rodrigo Mendonça dos Santos. 2021. Chilean Teacher Educators' Conceptions on the Absence of Women and Their History in Teacher Training Programmes. A Collective Case Study. Social Sciences 10: 106. https:// doi.org/10.3390/socsci10030106

Academic Editor: Delfín Ortega-Sánchez

Received: 27 January 2021

Accepted: 16 March 2021

Published: 19 March 2021

Publisher's Note: MDPI stays neutral with regard to jurisdictional claims in published maps and institutional affiliations.

Copyright: (c) 2021 by the authors. Licensee MDPI, Basel, Switzerland. This article is an open access article distributed under the terms and conditions of the Creative Commons Attribution (CC BY) license (https:// creativecommons.org/licenses/by/ $4.0 /)$

\begin{abstract}
Schools must assume a clear position that considers gender perspectives and studies in their programmes' construction as well as in discourses and practices produced and reproduced in the school context. Social sciences education is a key area that enables the creation of tools to reflect and foster social justice practices in face of violence against women. In this article, we focus on some reflections of social sciences education professors in Chile. Specifically, we discuss the limitations they face to include women and women issues in their classes. The methodology utilised is Collective Case Studies. The methodology used has a socio-constructivist approach and critical theory perspective, seeking to understand the structures of meaning around the invisibility of women and their history. Among the results, the willingness of professors to include and transform their practices towards perspectives that promote inclusion and social justice stands out. However, they have different limitations, such as excessive workload, the tradition already present in teacher education programmes, and the rigidity of the hegemonic and patriarchal structures.
\end{abstract}

Keywords: teacher training; women; education; conceptions

\section{Introduction}

From different theoretical perspectives in education, an urgency has been manifested that schools, teachers, and other educative actors rethink their practices and behaviours to subvert traditional gender structures (Levstik and Barton 2005; Crocco 2008; Lerner 1981; Lomas 2002; McIntosh 1983; Gràcia et al. 1993; Woyshner 2002). Schools and other educational institutions normalise traditional parameters regarding gender that perpetuate discrimination, segregation, stereotypes, and prejudices (Foucault 1976), reproduce discursive practices around inequalities, and marginalise women within the concept of diversity (Marolla 2019b; Ortega-Sánchez and Pagès 2018; Ortega-Sánchez et al. 2020). It must be considered that, from an educational and historiographical tradition, there are structures that have been responsible for producing and reproducing inequalities on the basis of gender (Massip et al. 2020; Sant and Pagès 2011).

Therefore, this study aims to reveal the gender structures manifested by professors when planning and executing the teaching and learning practices of history and social sciences. In this way, we expect to understand, know, and analyse spaces of possibility and the obstacles described by professors on the teaching staff in the face of the inclusion of women and their history in their the practices. This study carries practical implications for the fundamental interest and thus is related to delivering paths and ideas to teachers, as well as to management and curricular planning teams. We suggest that they reflect on their own gender constructions and generate transformations in the face of the inequalities that have been perpetuated in society. 
It is of great relevance to deliver ideas that address the limitations discussed by the study's participants. Despite the various ideas about innovation and the educational advantages that exist regarding the inclusion of women and their history in the teaching of history and social sciences, there are different barriers that traditionally affect teaching (Sant and Pagès 2011; Marolla 2019b; Ortega-Sánchez et al. 2020). Strictly speaking, they refer to hierarchical gender structures, derived from the patriarchal structures themselves, that have normalised such hierarchies. Within the heterosexual matrix (Foucault 1976), it is men who can express themselves in society and public spaces.

For the study, two main objectives guided the research:

1. Interpret the content of the professors' narratives about traditionality and spaces, in order to identify and generate changes in the teaching of history and social sciences.

2. Analyse the main advantages and limitations defined by participants when trying to include work on the inclusion of women and their history in the training of history and social sciences teachers.

\section{Theoretical Framework}

\subsection{Gender Structures in Educational Contexts}

Social studies, as an educational field of study, is concerned with the issue of gender structures in educational contexts. Works such as Luque and Rodríguez (2015), Marolla (2019a, 2019b), Massip and Castellví (2019), Ortega-Sánchez and Pagès (2018), Sant and Pagès (2011), Hahn et al. (2007), Schmeichel (2011), among others, have concluded that current educational practices must be rethought from current gender issues with the aim of including women and sexuality, and gender dissidence in the teaching and learning processes. These works coincide with the fact that curriculum, textbooks, and teachers' attitudes are conditioned by patriarchal structures that exclude topics such as human diversity, social issues, and the history of women (Fernández Valencia 2004; Valencia 2006; Winslow 2013). It is still a pending task to understand and unveil the structures under which women are included and problematized within history and to work from that approach (Woyshner 2002; Woyshner and Schocker 2015). Except for incipient investigations (OrtegaSánchez and Pagès 2018; Marolla 2019b, 2019a; Ortega-Sánchez 2017), it is difficult to find works in the educational field that deal with the groups that have been invisible throughout history. Furthermore, as Marolla (2019a) suggests, it is essential that studies focus on teacher practices, student learning, and the processes in classrooms that include or exclude women.

Some studies, such as Sant and Pagès (2011), Pagès and Villalón (2013), Cerecer and Pagès (2014), Pinochet (2015), Marolla (2015), and Ortega-Sánchez (2017), have shown that women and their history have been approached from the margins and absences, that is, many times as appendices or curious facts in a history built from masculinity. History and the teaching of history, the authors agreed, highlight the actions of powerful men in politics, the economy, and war. However, despite the research carried out on this topic, the problem persists, and women and their history continue to be taught from traditional logics and with male protagonists in a heteronomous story (Marolla 2019a, 2019b; Ortega-Sánchez and Pagès 2018; Ortega-Sánchez et al. 2020; Schmeichel 2011).

\subsection{Including Women and Women's History in Teaching Practices}

Women have been made invisible in a myriad of processes, and, when present, they are represented with prejudice and traditional gender stereotypes (Marolla 2019a). Scott (1996) stated that history is written excluding women and gender studies, and it is framed in patriarchal structures. At the same time, masculinity is configured under symbols and practices excluding women's actions. According to Butler $(1997,2011,2016)$ and Foucault (1976), the conceptualisation of identities is conditioned to multiple social, political, and cultural intersections that conform them. Bourdieu and Passeron (2018), Foucault (1976) and Wittig (1992) agreed that concepts are understood from perspectives such as class, race, sex, or ethnicity, and others that entail control, segregation, and marginalisation. Gender 
is not constructed in a coherent way; on the contrary, it depends on the perspectives previously named that, in general terms, are determined by heterosexual conventions on the ways of thinking and acting (Butler 2011, 2004, 2016).

Butler (1997) considered that it is necessary to reflect on the oppressive productions and reproductions formulated by the patriarchy. One of the aims of this reflection must be the rejection of fixed and immutable conceptions about identity, understanding that such aspects abide by power relations within determined sociohistorical contexts. For that reason, there are several historical movements that have sought to make women's actions and issues as visible as those of men (we refer to the actions transmitted from a tradition where protagonists are reflected in issues of politics, the economy, and war) (Massip et al. 2020). There are efforts to represent women from oppression and marginalisation, creating new periodisation and narratives departing from feminine historicity (Scott 1996). In the educational field, Giroux (2018) stated that, by including women and gender issues in teaching education, we can recover their history and their voices. To rethink education is fundamental to understanding concepts such as reproduction, hegemony, or gender hierarchies. In this way, it is possible to build new discourses and narratives, new political and cultural vocabularies that define different expressions and identities.

Research that inquires on the presence and absence of women in school curriculums and textbooks has shown that women's stories are entirely left out (Luque and Rodríguez 2015; Valencia 2006; Sánchez and Pintado 2006; Crocco 2008; Sant and Pagès 2011; Marolla 2015, 2019a, 2019b; Schmeichel 2011). As Banks (2008) stated, it is necessary to reflect on how knowledge has been constructed and how teacher education and teaching practices are being developed in relation to the inclusion and exclusion of women, their diversity, and their stories. Despite the importance of teacher education programmes for transforming educational practices, there are very few studies that inquire about the inclusion of women in history and social sciences teacher education (Crocco 2015b; Hess 2002; Levstik and Groth 2002; Woyshner 2002). As a consequence, teacher education programmes neither consider women nor their stories and narratives (Gutiérrez 1998; Vavrus 2009). Androcentrism is a historical and current issue that urgently requires our attention (Marolla 2019a).

Teachers are not educated for considering women's perspectives in education, and they think and plan their practices according to the socially most valued model, which is a male-centred model (Apple 1990; González 2002). As a consequence, androcentrism, sexual stereotypes, and the universality of male values as social and gender structures are transmitted, particularly in history and social sciences education (Hubbard 2013; Vázquez 2003) and school organisation, dynamics, teaching practices, and other related aspects, reproducing stereotypes and gender prejudices.

As teachers act as agents of transmission of values, they are capable of transmitting stereotypes, prejudices, and gender inequalities. Thus, it is fundamental to educate them to produce changes in education and to not reproduce gender inequalities by being attentive to the approaches and perspectives under which they teach history and social sciences. To generate social and educational change from a gender issues perspective, it is necessary to promote discourses that potentiate inclusion, empathy, diversity, and the construction of spaces that enable the empowerment of people who have been marginalised in the narratives (Sánchez and Pintado 2006; Heimberg 2005).

According to Crocco (2008) and Giroux (2018), gender problems obey patriarchal, androcentric, and heteronormative structures (Butler 2011; Foucault 1976) under which the Western educational system is organised. As a result, many gender issues could be shared between different educational contexts. The current study is positioned within the context of teacher education in Chile, the details of which we explain in the following section.

\section{Methodology}

The research we present is framed in a socio-constructivist approach, understanding reality as "a product of a symbolic dynamic that is generated in many social instances" (Stake 2013, p. 125). Along with Álvarez-Gayou (2003), Bryant and Jary (2014), Bisquerra 
and Alzina (2004), and Simons (2009), we understand the construction of knowledge as the attribution of meaning to a reality that has been socio-historically determined through contextual interaction. Thus, this research seeks to understand structures of significance around the absence and presence of women and their history in teacher education programs and teacher practices, characterising, defining, and explaining the construction of social representations and discursive practices in history and social sciences teaching (Ortega-Sánchez 2017).

This research is based on a collective case study (Stake 2013; Simons 2009), focused on exploratory (Yin 2009) and interpretive (Simons 2009) case studies. It takes a qualitative approach and, as such, is intended to explain and give relevance and complexity to the research topic (Álvarez-Gayou 2003; Creswell 2014; Stake 2013; Simons 2009). In order to comprehend the content of teacher educators' discourse, we used the principles of critical theory (Cohen et al. 2013; Álvarez-Gayou 2003), as well as the conceptions of feminist research (Cohen et al. 2013). The research is also framed in the transformational field (Creswell 2014), since this perspective intertwines political aspects, transformation, and the fight against oppression (Bryant and Jary 2014).

The participants that took part in the analysis and the reflection were three female and two male teacher educators in social sciences of different universities in Santiago de Chile. Following Ortega-Sánchez (2017), the participant selection depended on the researcher's criteria and not on a random sample selection, thus the selection criteria used were based on the degree of familiarity of participants to previously established objectives and categories of the analysis (Gómez et al. 1996). The sampling technique used had a non-probabilistic and non-stratified character (Hernández Sampieri et al. 2014), based on cohabitation (Cohen et al. 2013; Simons 2009; Creswell 2014), requiring participants to adequately meet the conditions for the purposes of the research (Table 1). For the selection of such participants, the following criteria were followed:

(a) Predisposition: Participants show their willingness to share their experiences.

(b) Type of university where they work (public-private).

(c) Previous training: all participants are graduates in history and education.

Table 1. Participants.

\begin{tabular}{cclc}
\hline Fictitious Name & University & Work Experience & Age \\
\hline Stella & Public & More than 15 years. & 36 \\
Polly & Private & More than 10 years. & 32 \\
Tammy & Public & More than 10 years. & 34 \\
Vince & Private & More than 15 years. & 35 \\
Fred & Public & More than 15 years. & 35 \\
\hline
\end{tabular}

For the presentation and discussion of the results, fictitious names were adopted to preserve participants' anonymity. This was done following the ethical criteria established by the Declaration of Helsinki. The participants signed an informed consent prior to the study, counting on the security of anonymity, and the security and permanent protection of the integrity of each person.

To obtain the information, semi-structured interviews were used, and the Bisquerra and Alzina (2004) method was used around the interviews as conversations. In this method of interviews and conversations, the aim was to create a climate of trust with the aim that informants could share their experiences in a fluid way. Aspects such as empathy and dialogue in the interviews were essential in obtaining valuable data for our research. Initially, some questions were prepared and tested under the validation of experts in social science teaching. Afterward, the questions were shared with the people to be interviewed (Álvarez-Gayou 2003). In addition, we use the "probes" strategy, following the approaches of Cohen et al. (2013), creating space in order to request clarifications or depth in the answers provided, which could lead to extensions, greater details or explanations of what 
participants have said in the interviews. The audio of the interviews was recorded with an audio system and later transcribed. The transcripts were sent to the participants, following the ethical criteria, in order to give the interviewees the possibility of adding data or requesting the deletion of information that they considered could affect their integrity.

To carry out the qualitative analysis of the information, the four phases proposed by Creswell (2014), Stake (2013) and Simons (2009), were followed: (1) reduction of the data, where a rigorous selection of the data was made in order to facilitate the information for analysis facilities; (2) analysis of the data and their organisation into categories, after the reduction phase the data were organised into categories based on the analysis; (3) interpretation using content analysis (Bardin 1991), creating patterns, concepts, and diagrams based on the objectives of the study. Categorical addition, categorisation, and coding were used to establish content categories. That is to say, after the establishment of categories, the interpretations were organised into a categorical sum based on the approaches of Bardin (1991), so we could later organise the interpretations from the categorical sum, to later be able to define patterns and schemes based on the objectives of the study; and (4) the ideological analysis, where the data were reflected upon and a discussion of the proposed theory was generated. This being the last phase after counting the categories, concepts and patterns from the content analysis, approaches were proposed in light of the theory, objectives and data that emerged from the study.

We analysed professors' secondary narratives and discourses from poststructuralist and feminist perspectives (Beasley 1999). This approach treated pluralities and differences, focusing on the subversion of categories such as identity, binaries, and relations, among others.

\section{Analysis of Results}

All professors interviewed agreed that schools impart norms, behaviours, and social patterns related to gender, class, and race aspects. Fred stated that, according to curricular research, images of social invisibility are transmitted from these spaces, contrasting with the visibility given to other characters: 'It [school] still transmits images of visibility, invisibility, thus; it still builds, it feels like we are still building a nation, the nation-state ... '.

Stella mentioned that, regarding the curriculum,

What is still being privileged is knowledge. To know content that is very connected to political history, economical history, and that, of course, sometimes references social history, but it is always very connected to political history ... that sort of explain the difficulties that teachers have when one tells them let's teach something else, let's give visibility to women and children.

This transmission, they agreed, acts on different levels. From the critical paradigm, Giroux (2018) and Apple (1990) explained that the transmission of social structures of power privileges some contents over others. Teacher educators recognised that education, particularly history and social science teaching, is based on the production and reproduction of national feelings, on reproducing a sense of belonging to a certain territory with broad nationalistic sentiments.

Stella stated that curricular construction privileges the teaching of factual content over processes, problems, and the diverse versions that exist concerning historical events. Actually, the contents of history and social science have connections with political history, economical history, and, in some cases, social history 'from masculine, patriarchal, and white perspectives.' (Stella).

Thus, instead of transforming structures, participants agreed that history and social sciences teaching have produced and reproduced gender hegemonies, placing white and powerful men as protagonists of accounts and narratives. Following Foucault (1976), the school would be in charge of the standardisation of gender identities and expressions. That is why the social patterns that portray women as subordinate continue to be reproduced. Teachers' practices, their actions, discourses, and teaching strategies have the possibility of producing, reproducing, as well as generating changes to unequal structures. 
For the professors interviewed, tradition is an obstacle for changing the approach in history and social science teaching programmes. As Vince stated, the dominant discourse standardises hegemonic and patriarchal structures of exclusion and subordination of women. This is how inequality, the processes, and the actions that have marginalised women are produced. As Vince added:

Even if there is a discourse that talks about diversity, finally what happens in the classroom depends on the teacher ... We talk about these men and these women, but we neither talk about all men nor about all women. Well, social history has kind of tried to incorporate this, but we talk about proletarian men and the rest is left aside...

Concerning this, tradition becomes a hegemonic construction with scarce variability. Conceptions of tradition have been utilised to thwart the inclusion of women, promoting the reproduction of historical and social gender structures (Villarroya et al. 2003). The protagonists are always men that have been prominent because of political, economic, and/or military power. Women who had any kind of power, or those women who have contributed to the construction of society with their work in everyday life, are invisible in these accounts.

Further, participants agreed when they stated that, despite the existence of a social tendency that promotes inclusion, most times the discourse, narratives, problems, and actions neither question nor reflect on the ways women are included, through the structures as well as the discursive accounts under which they are made visible. This discourse is built from patriarchal hegemony, and, therefore, excludes and subordinates not only women, but everything related to diversity, and that could generate changes in the androcentric traditional account. This way, inequality, stereotypes, and prejudices that revolve around participation and actions that have taken place from femininity are reproduced.

In addition to this, professors agreed that in accordance to what was aforementioned, immersed in an educational framework where patriarchal tradition predominates, when women are included, they become visible in actions that are 'proper to their gender' (Marolla 2019a, p. 23). That is, they are present in domestic chores, in the private sector and family care, amongst other classical stereotypes and prejudices that have surrounded women, in contrast to men, who are generally associated with war, politics, intellectuality and the public sector where apparently 'there were no women' (Marolla 2019b).

Foucault (1976) stated that tradition is the construct under which social structures and gender hierarchies have been validated and normalised; at the same time, these have generated oppression and social subordination over diversity. This comes into evidence, for example, in the construction of curriculums that reproduce dominant ideologies (Apple 1990; Giroux 2018; Valdés and Olavarría 1997). The exclusion of women is explained because the hegemonic culture is controlled by those who hold political, social, and economic power, which are white western men. They position their history, tales, and experiences as worthy of being historically transmitted in a way that is detrimental to women's narratives and memories.

For example, for Vince, the exclusion of diversity is directly related to the power of masculinity. Masculinity denies the opportunity to change the approaches and structures that can collaborate in the formation of multiple identities. According to participants, when a narrative or part of the history that was made by the actions of the traditionally excluded is revealed, it promotes identification with the purpose of generating empowerment and active political participation. For instance, when male and female students meet characters who have carried out different actions throughout history, an agency process leads them to become active citizens in their societies. From a gender perspective, education for citizen participation implies presenting the problem of inequalities and, at the same time, investigating the spaces and possibilities of fighting against inequalities caused by the same hierarchies and patriarchal social systems.

Regarding the above, Scott $(1996,2009)$ affirmed that history has been hierarchically constructed, positioning men as protagonists of history to the detriment of women's actions, 
memories, and narratives (Levstik and Barton 2005; Sant and Pagès 2011). Therefore, participants were in complete agreement regarding the potential of social science teaching to change practices and contribute to the construction of knowledge applicable to teaching practices.

Vince delved into the importance of transforming traditional teaching practices; since history has been taught from an androcentric perspective, this has excluded not only women, but also homosexuals, lesbians, and transgender people, among other absent identities. The possibility of changing approaches is denied because it fosters the formation of multiple identities and therefore empowers learners to be an active and critical part of society. Vince stated:

Because it homogenizes identities ... because one can identify with history, because one recognises someone, and when one says that one wants to be like this someone, when I recognise a revolutionary person, so; if there are no women, you are denying the chance to build women's inherent historical memory, or, for example, when no gays or lesbians are part of history ...

Therefore, the teaching of history and the social sciences must have an approach that privileges the treatment of problems, criticism, and the reflection on social inequalities. Especially focused on problems of gender discrimination. Valencia (2006) and González (2002) agreed that the structure and discourses that are transmitted in school reflect a passive and subordinate role for women compared to men, in which men have the leading role, as in stories from the teaching of history and the social sciences. It is fundamental, said Vince, that the constructions of what it is to 'be feminine' or 'to be masculine', and the power relations that have prevailed concerning these constructs are problematised. For Scott (1996), history and teacher education, built from male and endocentric conceptions, has reproduced a model of what it is to 'be a woman', and for that reason, schools have been producing and reproducing traditional roles based on gender categories.

Finally, professors affirmed that the ways in which the teaching of history and the social sciences are conceptualised are themselves obstacles, that is, the traditional frameworks that make up teaching. The official programmes on the teaching of history, in effect, are framed in the traditional perspectives that recognise masculinity and the dominant patriarchy. There is consensus that history has been socially constructed and, therefore, must be taught based on the actions and perspectives of the 'great men'. When working with women and diversity, the social representations of male and female students are broken by considering that what students are being taught is 'not history', since it is supposed to belong to an 'anecdotal' part of the 'really important' events, in which the actions of powerful men are highlighted.

In this regard, Tammy declared that there should be 'bridges' between the history that is taught and worked, and what is done from didactics. In particular, there should be links between academic knowledge and gender movements, focused on school learning and student training. Tammy acknowledged, as previously mentioned, that although her programme seeks to problematise women, including these approaches is still a pending task. Stella added that male and female teachers of didactics should ask themselves 'if history is not useful for solving the problems I have now, why should I teach it?'

Professors explicitly mentioned their intention to encourage understanding of the present and its diversity; however, classroom practices are contained within the scope of skills focused on the biographies of powerful men, wartime conflict, and male involvement in business activities. Although they position education for citizenship as one of the central objectives of their class, they do not operate with the lenses of citizen participation based on gender issues and the absence of women as historical subjects. Therefore, educational dynamics reflect the social constructions that have made women invisible and reproduced hierarchies, gender inequalities, and relegated women to the role of spectators. Professors spoke from a context in which affirming gender issues is not foregrounding the teaching of history and the social sciences. All this confirmed the approaches presented in the theoretical framework. Therefore, we argue it is essential that women and their history, 
as well as gender issues, have a leading position as content and practice in the teaching of history and social sciences.

\section{The Chances to Include Women and Their History in Social Sciences Teaching}

Participants also highlighted the possibilities of including and working with women and diversity in general. This is beneficial in the context of constant problems and demands that educators must address against gender violence and in favour of social justice. The professors, therefore, agreed that the models used to build history must undergo constant reflection, and that the stories and narratives about women must become visible. They agreed that the teaching of history and social sciences must be rethought in order to include problems from a gender perspective, such as the relevant social problems that have caused, produced and reproduced discrimination, absence, and marginalisation of gender and women from historical categories. As Villuendas and López (2003) and Wittig (1992) said, questioning the discourses about women must account for the spaces of normalisation and naturalisation that have been transmitted regarding the roles and identities about 'being a woman' (Butler 1997; Schmeichel 2011; Schmidt 2012).

Crocco (2008) agreed with the comments made by participants that when women become invisible in history or, in some cases, are presented as an appendix to traditional male history, boys and girls do not have models to identify with and empower themselves; therefore, they do not fight against inequalities since they understand that their stories, women's stories, and everyday stories are not relevant. Their actions in the construction of history do not stand out, and they seem irrelevant to society. Stella, for example, explained that stories and narratives are predominantly masculine, but they do not represent all men. Rather, they are limited to those men who are white and who have had political, economic, and/or military power. When women are included, it is because they showed some kind of similarity with these men (Valdés and Olavarría 1997; Hess 2002; Badinter 1993; Banks 2008; González 2002; Gutiérrez 1998).

Stella argued that the characters included are 'the elite ... a few men, presidents, soldiers who participated in some war, and who were important, who became heroes ... from time to time a woman, but I think they are seen because they have masculine characteristics ... The history of women is taught from a very anecdotal point of view' (Silva 2016; Heimberg 2005; Sánchez and Pintado 2006; Winslow 2013).

Polly, for example, commented that women are included in a very superficial way in history, as well as in didactics. The few women included are portrayed as 'great women', highlighting masculine characteristics rather than femininity itself (Crocco 2008; Fernández Valencia 2004; Sánchez and Pintado 2006). This generates a partial vision of the construction of history, provoking the conception that men, and specifically the patriarchy, have been the only participants in the construction of society and history (Scott 2009).

Fred emphasised the wide range of possibilities offered by the didactics of the social sciences to promote changes in traditional structures. The professor said that, from this area, it is possible to have a teacher education that encourages reflection and criticism of discourses, versions of history, and narratives: 'We have to make a change on historiographic discourses and narratives ... they have to give evidence of the incorporation of visibility ... ' (Fred 2016). Butler (2004, 2011), postulated, in accord with what participants have said, that there are ample spaces for the transformation of traditional narratives that have marginalised gender diversity, and proposed to society the questioning of versions, the normalisation, and naturalisation of the subordinate position that has been given to women, as well as diversity and multiple expressions of identity (Beasley 1999; Cerecer and Pagès 2014; Massip et al. 2020).

In order to put the aforementioned into practice, teachers could establish a break with traditional structures of teaching and learning history and social sciences, emphasising stories and narratives that relate how gender has been constructed and, therefore, how it has generated oppression against diversity (Ortega-Sánchez and Pagès 2018). The inclusion of women in the teaching of history and social sciences, according to participants, should 
not be taught through themes, anecdotal data, or appendices to an androcentric history, but as an inclusion that proposes criticism and reflections about the topic (Woyshner 2002; Vavrus 2009) and the traditional and sexist structures under which history and its teaching have been built. Agreeing with these perspectives, Vince said that he would promote reflection aimed at a fairer and more inclusive society, respectful of diversity and human rights. For Vince, it is not a good idea to use structures that already exist to include women in history, but rather to problematise these structures and show the anecdotal and subordinate position to which women and diversity have been relegated. Therefore, structures could be promoted that would denature the hegemonic constructions that have been built by the patriarchy (Crocco 2008; Gutiérrez 1998; Villarroya et al. 2003; Hess 2002).

Professors agreed that positioning aspects such as criticism, reflection, and the denaturing of traditional structures of history in teaching could make women visible and make diversity visible in their daily actions, contributing to society (Marolla 2019a; Massip et al. 2020). Therefore, boys and girls could identify with these role models and understand that they can be part of and build history themselves, as fundamental protagonists in the construction of processes and spaces of historical change towards social justice, and most importantly, builders of a fairer future (Ross 2012; Levstik and Groth 2002; Cerecer and Pagès 2014).

Vince affirmed that didactics must consider how gender has been constructed and how structures of oppression towards diversity have been established. However, he argued that such structures should be raised not from the perspective of professors, but from students own reflections on social and gender structures (Banks 2008; McIntosh 1983). Vince affirmed that the objective in his classes is to develop positions and critical thinking about gender oppressions, such as discrimination, prejudice, and stereotypes that perpetuate violence. The training should focus on: 'a teacher who can show the diverse, the reality, since in that logic there is a discourse that includes the theme of women, of diversity ... there is also a diversity of identities ... it seems that they are still seeing only a part of the diversity ... ' (Vince 2016).

Participants agreed that a useful tool to achieve what has been said above is positioning and transforming a curriculum based on objective content into a curriculum based on relevant social problems (Sant and Pagès 2011), which makes women visible as actors in the construction of new structures outside the patriarchy (Scott 1996). This implies that the chronologies, phases, processes, concepts, dynamics, stories, and narrations of the actions of male and female characters should be rethought and transformed. Women and diversity cannot be included in the frameworks created by patriarchy because implicit oppression and subordination will continue to exist (Hahn et al. 2007; Heimberg 2005; Hess 2002; Hubbard 2013).

They understood that reflecting on the discourse and processes under which women have been included in the teaching of history and social sciences could represent a contribution to the fight against discrimination and gender inequality (Massip and Castellví 2019). The teachers believed that to fight the aforementioned problems, it is essential to reflect on the traditions that have led to such practices. For this reason, teacher educators expressed the problem of having a traditional history discipline based on great characters. They manifested the interest to include transformative perspectives on the teaching and learning of history from spaces that dismantle traditional structures of gender (Crocco 2008; Gràcia et al. 1993; Vavrus 2009).

The information provided by professors about their practices and training processes they carry out showed that society has established hierarchies where women occupy subordinate positions (Ortega-Sánchez and Pagès 2018; Marolla 2019a). History and social science teaching takes place under conditions that do not encourage reflection about problems that women have experienced and are currently experiencing. Participants emphasised the importance of creating spaces for the inclusion of women as a means to combat discrimination and inequality (Badinter 1993; Cerecer and Pagès 2014; Fernández Valencia 2004). On the other hand, teaching practices tend to base learning on curriculum 
and traditional history, which generally represents the highly recurring presence of powerful men. Teaching practices in history and social sciences are based on political and/or economic issues, as well as on war, excluding women and their experiences, all of which cause inequalities to occur and to be reproduced from school spaces to social spaces and structures (Crocco 2015a; Luque and Rodríguez 2015; Lomas 2002; Heimberg 2005).

\section{Discussion}

Participants identified various advantages and limitations. Among the limitations, they agreed on the small and scarce role of the initial formative stages. They also mentioned the difficulties and the control imposed by the national curriculum and central administration, pushing them to teach the 'official' version of the story, seeking better results on standardised tests. Hence, the official curriculum is reaffirmed by participants as programmes do not provide spaces or possibilities for teachers to generate innovation, content, and practices from gender perspectives (Hess 2002; Crocco 2015b; Crocco 2008).

The importance that participants assigned to the inclusion of women is related to the possibility of social transformation (Beasley 1999; González 2002; Gutiérrez 1998). By posing questions and reflecting on discourse, space can be created for social transformation against gender inequality. The idea and approach that affirm the need to deconstruct traditional structures are reaffirmed, not only from the content with which they work, but also from the professors' own practices (Marolla 2019b; Ortega-Sánchez et al. 2020). This entire structure is part of the educational androcentrism that has perpetuated discrimination, the invisibility of women, and the rest of non-traditional gender structures (Foucault 1976; Hahn et al. 2007).

Participants commented on various advantages and limitations regarding the inclusion of women and the teaching of their history. Among the former, and in agreement with what is presented in the theoretical framework, they affirmed that in schools teachers are largely conditioned by curricular impositions (Vázquez 2003; Sánchez and Pintado 2006). Standardised tests are based on official history, tradition, and a focus on male and white characters. Learning the official history is what leads students to obtain good scores in these tests, and teachers have to teach said content in their classes, reinforcing such protagonists and historical dynamics (Scott 2009; Sant and Pagès 2011; Pinochet 2015).

Participants affirmed that the inclusion of women in the teaching of history and social sciences can encourage the development of spaces that motivate citizen participation (Ortega-Sánchez and Pagès 2018; Ross 2012). They recognised that they must challenge the discourses that make women visible and invisible. They also proposed that the problem lies in the discourse about women, which makes girls reproduce and perpetuate traditional models. The problem is not inclusion, but the type of discourse that makes women visible (Marolla 2019a, 2019b; Massip et al. 2020).

Among the relevance of the results obtained from the participants, we can affirm that the way women are portrayed in textbooks, in the school curriculum or the content of the class used by teachers transmits an androcentric image or perception of the experiences of women, youth, and adolescents (Woyshner 2002). Girls will identify with these images and reproduce them, that is, they will continue to maintain hierarchies and gender hegemonies in which they are positioned as subordinate to men (Crocco 2008; Fernández Valencia 2004; Lomas 2002). Similarly, if historical facts and history in general keep being transmitted through empowered white male protagonists who have been successful and have excelled in all aspects of society, white young boys and adolescents will grow up believing they are the only ones capable of leading movements and bringing about change in society (Ross 2012).

Participants' accounts were aligned with the theoretical perspectives presented in this paper, and even more, they affirmed that innovation must be the base of the practices they carry out. It should be noted that the innovation of the didactics to which they referred is not framed in the innovations proposed by the constructivist currents (Giroux 2018), but 
refers to the deconstruction of the androcentric structures under which teaching has been conceived and reproduced (Villuendas and López 2003; Valencia 2006).

Joint efforts must be made towards curricular reform, eliminating sexism and androcentrism in schools (Villarroya et al. 2003). Teaching practices should consider different gender perspectives and focus on the roles, identities, and experiences of men and women in history (Scott 2009; McIntosh 1983; Schmidt 2012). For this reason, innovation in didactics is essential so it includes different materials for teaching and learning social sciences and history, as well as materials built on different gender perspectives (Villarroya et al. 2003; Vázquez 2003; Winslow 2013). It can be highlighted that teachers are willing to generate changes focused on the development of critical thinking, the formation of citizenship, and the questioning of androcentric identities in history (Sant and Pagès 2011; Ortega-Sánchez et al. 2020).

Therefore, professors interviewed in this paper proposed to create climates of tolerance, respect, inclusion, and gender diversity in classes (Marolla 2019a; Cerecer and Pagès 2014; Hubbard 2013). Participants suggested that teaching practices should not be limited to the transmission of content, but rather, to transform educational spaces to include differences and allow participation. Teachers argued that is important to empower students to manifest and fight against gender inequality (Gutiérrez 1998; Hahn et al. 2007). However, if they do not have the support of their respective schools and teachers, students will not be able to implement these transformations, since they will not have the space to do so (Woyshner and Schocker 2015; Schmeichel 2011; Cerecer and Pagès 2014; Levstik and Groth 2002).

From the educational exercise itself, it is necessary to promote teaching practices that promote social justice and the recognition of gender diversity (Ross 2012; Schmeichel 2011; Ortega-Sánchez 2017). All were willing to make commitments, generate changes and innovate in what they do to transform learning processes and society in general; however, if no updating tools are delivered from the curriculum or from teacher professional development, teaching will continue to reproduce inequalities (Villarroya et al. 2003; Sant and Pagès 2011; Marolla 2015, 2019a, 2019b).

Considering the advantages of the inclusion of women both in the curriculum and in the practices carried out by teachers, participants agreed that to clearly define and implement inclusive scenarios, teachers' willingness to contribute to this kind of formative process, the participation of educational centres and teaching practices are of vital importance (Winslow 2013; Villarroya et al. 2003; Vázquez 2003; Vavrus 2009). It is noteworthy that the professors thought that teacher education and teaching practices should be rethought to take into account women's experiences from a critical perspective, aimed at transforming gender inequality.

It is crucial that the organisation of the school is questioned from a perspective that provides space and favours the presence and participation of all, regardless of gender (Crocco 2015a). Although this is a complex goal, a perspective that fosters critical thinking about structural inequalities from a gender perspective should be central. One of the ideas that was raised is the creation of materials that address the experiences of women and propose reflection and consideration of current social constructions (Woyshner and Schocker 2015; Woyshner 2002; Hahn et al. 2007).

Teaching practices that incorporate objectives of social justice, inclusion, and citizen participation should be promoted, considering everyone as equals in their differences (Massip and Castellví 2019; Massip et al. 2020). The focus should be on citizen participation and commitment to the fight against gender inequalities, helping students to identify with social models and a history built around women, recognising and celebrating their actions and experiences (Valencia 2006; Ross 2012; Luque and Rodríguez 2015).

All professors interviewed recognised that one of the main limitations when trying to include women and their history in their teaching practices is the curriculum and the ministerial policies that normalise the discourse and strengthen the construction of identity and passive, subordinate, and non-participatory roles (Winslow 2013). Such roles, 
in general, are associated to the construction of 'being a woman', as a role and gender subordinated by the predominance of men (Badinter 1993; Valdés and Olavarría 1997).

Traditional perspectives in teacher education and teaching practices do not deepen critical thinking and do not question the discourse transmitted through the teaching and learning of history. History teaching is focused on school curricular guidelines based on the transmission of androcentric structures of history (Marolla 2015) in which white, powerful and straight men are the protagonists of the stories. The pressure to teach these guidelines increases due to the pressures of the standardised tests, which are built from the ministerial requirements (Butler 2004; Fernández Valencia 2004; González 2002). It is not less important to highlight that in the Chilean context the results of standardised tests determine the financing schools receive from the government. The better the scores the greater are the resources received by the school, so the pressures to continue teaching traditional perspectives are rooted in training practices (Marolla 2019a, 2019b; Ávalos 2014).

When women are included in ministry policies and within the curriculum and traditional structures of history and the social sciences, they appear as 'spectators' (Woyshner and Schocker 2015; Woyshner 2002) of history. That is, in a way annexed to a story starring powerful men (Beasley 1999). Due to social hierarchies, produced and reproduced both by society and by educational structures, the absence of women and sexual dissent has been normalised in favour of the construction of history centred on male protagonists. In this context, education is a transmission of the social order itself that is reproduced in society (Bourdieu and Passeron 2018; Heimberg 2005).

Therefore, when women are included in practices and the curriculum they are reflected similarly to the roles traditionally assigned to men (Gràcia et al. 1993; Gutiérrez 1998; Hess 2002; Hubbard 2013). In other words, they include women who have also had political, economic, and warfare power, generating assimilation and reproduction of the power structures and normalised hierarchies that maintain the status quo concerning gender perspectives (Sant and Pagès 2011; Pagès and Villalón 2013; Massip et al. 2020).

The current economic system collaborates to normalise class and gender inequality, linking women to private and domestic roles. This is contrary to the emphasis given to men as leaders both in public spaces and in the workplace. This is evidenced in current investigations (Banks 2008; Hahn et al. 2007; Crocco 2008; Sánchez and Pintado 2006). Women and their stories, when they become visible in educational processes, are portrayed in public spaces, assuming roles traditionally assigned to women (Beasley 1999; Gutiérrez 1998; Gràcia et al. 1993).

\section{Conclusions}

As participants have stated, it is essential to rethink how teachers are trained, including spaces for reflection and analysis on the discourse under which women and the range of gender diversity have become invisible and excluded. Teacher education must consider the invisibility of women and other groups and suggest new ways of classifying history, questioning current social constructions and bringing new problems to the classroom.

As the different participants in the current study agreed, teaching practices should focus on aligning discourse with action. Participants suggested a framework of possibilities that should be translated into practices aimed at transforming gender inequality. One way to do this is to reflect on existing structures and reveal the ultimate purpose and objectives sought, for example, by the curriculum, textbooks, and school administration (González 2002; Gutiérrez 1998; Levstik and Barton 2005; Lomas 2002; Villarroya et al. 2003).

Teacher education should provide ideas and tools to promote teaching practices that focus on aspects of emancipation and the visibility of non-traditional roles for women. The formative processes of teachers must analyse and reflect on the structures on which history has been built. If they could promote more reflective teaching practices that encompass the teaching and learning of history and the social sciences, they would have as much potential to deconstruct social constructs as they now have to promote the reproduction of inequality. This is essential to revealing the implicit meaning in discourses and the structures of gender, 
class, or ethnicity included in the teaching of the aforementioned subjects. Teachers must be critical of their own actions and be able to understand the perspectives under which certain processes, discourses, or protagonists become visible or invisible.

The deconstruction of social structures in teacher education must enable teachers to rethink the final objectives of teaching practices and learning and deconstruct gender hierarchies and the subordination that has led to the marginalisation, abuse, and obscuring of women. Performativity (Butler 1997, 2011, 2016) can constitute a theoretical and practical tool used to collaborate in uncovering how gender structures have worked and how new alternatives can be built to combat monopolised power in the form of patriarchy.

Formative processes should consider the use of materials and alternative theoretical perspectives to those traditionally used. Materials that gather and question content from a gender perspective can provide options in the struggle against oppression and the reproduction of roles and identities passed on, worked on, and currently existing in classrooms.

Questioning current gender construction and structures is key to promoting transformation of the status quo. Questioning them should create spaces with a climate of real possibility in the classroom. These spaces should focus on the participation and empowerment of students in the struggle against gender inequality.

\section{Limitations}

Regarding limitations, it is possible to mention the scale covered by the study. That is, it is only analysed and discussed on the basis of a specific sample of Chilean professors. Hence, there is no possibility of generalising the findings, as well as of transferring such ideas to other contexts and realities. Although the contexts and problems addressed in the study for gender reasons are similar, the results discussed are specific to the case study carried out. We argue, though, that the study presents the possibility to apply some paths, ideas, tools and spaces of possibility that can be applied in other educational contexts.

In addition, among the limitations, it is possible to point out the large amount of information provided by the interviews. It is difficult to select from and analyse the large amount of data that was available. Despite the existence of different sources of educational material stemming from the social sciences that considered gender perspectives in teaching practices and learning, the experiences and problems of women are not included in formative processes or teaching practices.

Finally, it is recommended that studies that propose the analysis of gender perspectives in the teaching and learning of history and social sciences delve into the practices carried out by teachers.

It can be mentioned that the main projection of the research is related to two perspectives. The first is being able to replicate the methodological structure in new studies that delve into other contexts and realities from the purposes established by the study. Second, it is necessary to carry out quantitative studies on a larger scale on the reality and conceptions of teachers regarding the inclusion of women and gender perspectives in the teaching of history and social sciences.

In the same way, it is relevant that, from the ideas raised in the study, studies are proposed that investigate the teaching practices carried out by the teaching staff from the inclusion of gender perspectives. On the other hand, it is argued that the objective of the studies on such themes has an impact on the teacher practices. Likewise, the changes proposed in the paper are related to deep-rooted structures of society.

Participants recognised the questions being asked and the gender structures they themselves are part of. They recognised themselves as part of the problem; however, they put forward a scenario that mobilises the possibility of transforming inequality. These professors were willing to transform inequality and work collaboratively and inclusively with everyone participating and forming part of teaching and learning processes.

However, it can help the teachers to reflect on their own thinking about gender structures, and from such perspectives, to promote changes in the practices that have 
contributed to the reproduction of inequalities. In the same way, the findings found in the study can help those in charge of the construction of teacher training programmes and the history and social sciences curriculum developers to reflect on the perspectives and structures that are being made visible. That is, the spaces for change and transformation that arise from the programmes and the curriculum, as well as the spaces that continue to reproduce the structures of inequality. In this way, as stated before, it is optimistic to expect profound changes in the face of structures, hierarchies, and gender hegemonies that have traditionally been perpetuated throughout history; however, studies such as this one represent spaces of possibility and transformation both for teachers as well as for management teams.

\section{Ethics Statement}

This study was carried out in accordance with the recommendations of Research Ethics in Education of the University of the Americas, Chile. The protocol was approved by University of the Americas, Chile. All subjects gave informed consent in accordance with the Declaration of Helsinki.

Author Contributions: Conceptualization, J.M.G. and J.C.M.; methodology, J.M.G.; J.C.M. and R.M.d.S.; software, J.C.M.; validation, J.M.G. and R.M.d.S.; formal analysis, J.M.G., J.C.M. and R.M.d.S.; investigation, J.M.G., J.C.M. and R.M.d.S.; resources, J.M.G.; data curation, J.C.M.; writingoriginal draft preparation, J.M.G., J.C.M. and R.M.d.S.; writing-review and editing, J.M.G., J.C.M. and R.M.d.S.; visualization, R.M.d.S.; supervision, J.C.M.; project administration, J.M.G. All authors have read and agreed to the published version of the manuscript.

Funding: This research was funded by University of Americas, Chile, grant number UA1016. The main researcher is Professor Jesús Marolla Gajardo (University of Americas, Chile).

Institutional Review Board Statement: The study was conducted according to the guidelines of the Declaration of Helsinki, and approved by the Ethics Committee of University of the Americas (REX $\mathrm{N}^{\mathrm{o}} 123120$ 08/06/2020).

Informed Consent Statement: Informed consent was obtained from all subjects involved in the study.

Data Availability Statement: Not applicable.

Conflicts of Interest: The authors declare no conflict of interest.

\section{References}

Álvarez-Gayou, Juan Luis. 2003. Cómo Hacer Investigación Cualitativa. Madrid: Paidos Iberica Ediciones.

Apple, Michael W. 1990. Ideology and Curriculum. Madrid: Psychology Press.

Ávalos, Beatrice. 2014. La Formación Inicial Docente en Chile: Tensiones Entre Políticas de Apoyo y Control. Estudios Pedagógicos (Valdivia) 40: 11-28. [CrossRef]

Badinter, Elisabeth. 1993. XY la Identidad Masculina/XY the Male Identity. Madrid: Alianza Editorial.

Banks, James A. 2008. Diversity, Group Identity, and Citizenship Education in a Global Age. Educational Researcher 37: 129-39. [CrossRef]

Bardin, Laurence. 1991. Análisis de Contenido. Bardin: AKAL.

Beasley, Chris. 1999. What Is Feminism?: An Introduction to Feminist Theory. London: SAGE.

Bisquerra, Rafael, and Rafael Bisquerra Alzina. 2004. Metodología de la Investigación Educativa. Barcelona: Editorial La Muralla.

Bourdieu, Pierre, and Jean-Claude Passeron. 2018. La Reproduction: Éléments pour une Théorie du Système D'enseignement. Paris: Editions de Minuit.

Bryant, Christopher, and David Jary. 2014. Giddens' Theory of Structuration: A Critical Appreciation. London: Routledge.

Butler, Judith. 1997. The Psychic Life of Power: Theories in Subjection. Palo Alto: Stanford University Press.

Butler, Judith. 2004. Undoing Gender. London: Routledge.

Butler, Judith. 2011. Gender Trouble: Feminism and the Subversion of Identity. London: Routledge.

Butler, Judith. 2016. Deshacer el Género. Barcelona: Grupo Planeta Spain.

Cerecer, Osvaldo Mariotto, and Joan Pagès. 2014. Los actores invisibles de la Historia: Un estudio de caso de Brasil y Cataluña. In Una Mirada al Pasado y un Proyecto de Futuro: Investigación e Innovación en Didáctica de las Ciencias Sociales. Barcelona: Servei de Publicacions, vol. 2, pp. 37-44. ISBN 978-84-490-4420-5. Available online: https://dialnet.unirioja.es/servlet/articulo?codigo=47 00388 (accessed on 27 May 2019). 
Cohen, Louis, Lawrence Manion, and Keith Morrison. 2013. Research Methods in Education. London: Routledge.

Creswell, John W. 2014. Research Design: Qualitative, Quantitative, and Mixed Methods Approaches. Los Angeles: SAGE.

Crocco, Margaret. 2008. Gender and Sexuality in the Social Studies. In Handbook of Research in Social Studies Education. London: Routledge, pp. 172-96.

Crocco, Margaret Smith. 2015a. Social Studies Today: Research and Practice. Edited by Walter C. Parker. London: Routledge.

Crocco, Margaret Smith. 2015b. Using Literature to Teach About Others: The Case of Shabanu. In Social Studies Today. Los Angeles: Routledge. [CrossRef]

Fernández Valencia, Antonia. 2004. Las Mujeres en la Historia Enseñada: Género y Enseñanza de la Historia. Clío Asociados. La Historia Enseñada, 115-28. [CrossRef]

Foucault, Michel. 1976. Histoire de La Sexualité (Tome 1)—La Volonté de Savoir. Paris: Editions Gallimard.

Giroux, Henry. 2018. Pedagogy and the Politics of Hope: Theory, Culture, and Schooling: A Critical Reader. Los Angeles: Routledge.

Gómez, Gregorio Rodríguez, Javier Gil Flores, and Eduardo García Jiménez. 1996. Metodología de la Investigación Cualitativa. Malaga: Aljibe.

González, Amparo Tomé. 2002. Luces y sombras en el camino hacia una escuela coeducativa. In Mujer y Educación: Educar para la Igualdad, Educar Desde la Diferencia. Barcelona: Graó, pp. 169-82. ISBN 84-7827-268-2. Available online: https://dialnet.unirioja. es/servlet/articulo?codigo=607488 (accessed on 7 April 2020).

Gràcia, Maribel García, Helena Troiano i Gomà, Miguel Zaldívar Sancho, and Marina Subirats Martòri. 1993. El Sexismo en los Libros de Texto: Análisis y Propuesta de un Sistema de Indicadores. Available online: https://dialnet.unirioja.es/servlet/libro?codigo= 193430 (accessed on 7 April 2020).

Gutiérrez, Ana María Alonso. 1998. El sexismo en el aula. In Los Valores y la Didáctica de las Ciencias Sociales: Actas del IX Simposium de Didáctica de las Ciencias Sociales. Lleida: Edicions de la Universitat de Lleida, pp. 309-16. ISBN 84-89727-73-2. Available online: https:/ / dialnet.unirioja.es/servlet/articulo?codigo=556098 (accessed on 7 April 2020).

Hahn, Carole L., Jane Bernard-Powers, Margaret Smith Crocco, and Christine Woyshner. 2007. Gender Equity in Social Studies. Edited by Susan Klein. In Handbook for Achieving Gender Equity through Education. New York: Routledge, pp. 335-57.

Heimberg, Charles. 2005. L'alterite et le multiculturalisme au coeur de l'histoire enseignee. In Enseñar Ciencias Sociales en una Sociedad Multicultural: Una Mirada Desde el Mediterráneo. Almería: Servicio de Publicaciones, pp. 17-32. ISBN 84-8240-755-4. Available online: https:/ /dialnet.unirioja.es/servlet/articulo?codigo=1980358 (accessed on 13 April 2020).

Hernández Sampieri, Roberto, Carlos Fernández Collado, and María del Pilar Baptista Lucio. 2014. Metodología de La Investigación. Mexico D.F.: Mcgraw-hill.

Hess, Diana. 2002. Discussing Controversial Public Issues in Secondary Social Studies Classrooms: Learning from Skilled Teachers. Theory and Research in Social Education 30. [CrossRef]

Hubbard, Phil. 2013. Kissing Is Not a Universal Right: Sexuality, Law and the Scales of Citizenship. Geoforum 49: 224-32. [CrossRef]

Lerner, Gerda. 1981. The Majority Finds Its Past: Placing Women in History. Oxford: Oxford University Press.

Levstik, Linda S., and Keith C. Barton. 2005. Doing History: Investigating with Children in Elementary and Middle Schools, 3rd ed. Mahwah: Lawrence Erlbaum Associates.

Levstik, Linda S., and Jeanette Groth. 2002. "Scary Thing, Being an Eighth Grader:" Exploring Gender and Sexuality in a Middle School U.S. History Unit. Theory and Research in Social Education 30: 233-54. [CrossRef]

Lomas, Carlos. 2002. El sexismo en los libros de texto. In Mujer y Educación: Educar para la Igualdad, Educar Desde la Diferencia. Barcelona: Graó, pp. 193-222. ISBN 84-7827-268-2. Available online: https://dialnet.unirioja.es/servlet/articulo?codigo=607490 (accessed on 10 December 2019).

Luque, Antonia García, and Matilde Peinado Rodríguez. 2015. LOMCE: ¿es posible construir una ciudadanía sin la perspectiva de género? IBER Didáctica de las Ciencias Sociales, Geografía e Historia 80: 65-72.

Marolla, Jesús. 2015. ¿Qué sabemos sobre la enseñanza de la historia de las mujeres? Algunas reflexiones sobre los discursos del profesorado chileno. In Una Enseñanza de las Ciencias Sociales para el Futuro: Recursos para Trabajar la Invisibilidad de Personas, Lugares y Temáticas. Cáceres: Universidad de Extremadura, pp. 889-97. ISBN 978-84-606-6444-4. Available online: https: / / dialnet.unirioja.es/servlet/articulo?codigo=5093283 (accessed on 6 September 2020).

Marolla, Jesús. 2019a. La ausencia y la discriminación de las mujeres en la formación del profesorado de historia y ciencias sociales. Revista Electrónica Educare 23: 137-57. [CrossRef]

Marolla, Jesús. 2019b. La inclusión de las mujeres en las clases de historia: Posibilidades y limitaciones desde las concepciones de los y las estudiantes chilenas. Revista Colombiana de Educación 1. [CrossRef]

Massip, Mariona, and Jordi Castellví. 2019. Poder y diversidad. Los aportes de la Interseccionalidad a la didáctica de las ciencias sociales. Clío: History and History Teaching 45: 139-54.

Massip, Mariona Massip, Jordi Castellví, and Joan Pagès. 2020. La historia de las personas: Reflexiones desde la historiografía y de la didáctica de las ciencias sociales durante los últimos 25 años. Panta Rei. Revista Digital de Ciencia y Didáctica de la Historia 14: 167-96. [CrossRef]

McIntosh, Peggy. 1983. Interactive Phases of Curricular Re-Vision: A Feminist Perspective. Working Paper No. 124. Wellesley: Center for Research on Women, Wellesley College. 
Ortega-Sánchez, Delfín. 2017. Las Mujeres en la Enseñanza de la Historia y de las Ciencias Sociales. Estudio de caso en Formación Inicial de Maestros y Maestras de Educación Primaria. Universitat Autònoma de Barcelona. Available online: https://dialnet. unirioja.es/servlet/tesis?codigo=136850 (accessed on 6 September 2020).

Ortega-Sánchez, Delfín, and Joan Pagès. 2018. Género y Formación Del Profesorado: Análisis de Las Guías Docentes Del Área de Didáctica de Las Ciencias Sociales. Contextos Educativos. Revista de Educación 21: 53-66. [CrossRef]

Ortega-Sánchez, Delfín, Jesús Marolla, and Davinia Heras. 2020. Invisibilidades sociales, identidades de género y competencia narrativa en los discursos históricos del alumnado de educación primaria. In Educación para el Bien Común: Hacia una Práctica Crítica, Inclusiva y Comprometida Socialmente. Barcelona: Octaedro, pp. 89-103. ISBN 978-84-18083-56-3. Available online: https:/ / dialnet.unirioja.es/servlet/articulo?codigo=7272067 (accessed on 6 September 2020).

Pagès, Joan, and Gabriel Villalón. 2013. Los niños y las niñas en la historia y en los textos históricos escolares. Analecta Calasanctiana: Publicación Semestral Religioso Cultural y de Investigación Histórica 109: $29-66$.

Pinochet, Sixtina Pinochet. 2015. Mirándonos al espejo: Los estudiantes frente a los niños, niñas y jóvenes como protagonistas de la historia. In Una Enseñanza de las Ciencias Sociales para el Futuro: Recursos para Trabajar la Invisibilidad de Personas, Lugares y Temáticas. Badajoz: Universidad de Extremadura, pp. 967-76. ISBN 978-84-606-6444-4. Available online: https://dialnet.unirioja.es/servlet/ articulo?codigo $=5097564$ (accessed on 12 September 2020).

Ross, E. Wayne. 2012. La educación para una ciudadanía peligrosa. Enseñanza de las Ciencias Sociales 11: 73-86.

Sánchez, Caridad Hernández, and Margarita del Olmo Pintado. 2006. Identidad y educación: Una perspectiva teórica. IBER: Didáctica de las Ciencias Sociales, Geografía e Historia 47: 7-13.

Sant, Edda, and Joan Pagès. 2011. ¿Por qué las mujeres son invisibles en la enseñanza de la historia? Historia Y Memoria 3: 129-46.

Schmeichel, Mardi. 2011. Feminism, Neoliberalism, and Social Studies. Theory and Research in Social Education 39: 6-31. [CrossRef]

Schmidt, Sandra J. 2012. Am I a Woman? The Normalisation of Woman in US History. Gender and Education 24: 707-24. [CrossRef]

Scott, Joan. 1996. Feminism and History. New York: Oxford University Press.

Scott, Joan Wallach. 2009. Género e Historia. San Diego: Fondo De Cultura Economica.

Simons, Helen. 2009. Case Study Research in Practice. Los Angeles: SAGE.

Stake, Robert E. 2013. Multiple Case Study Analysis. Los Angeles: Guilford Press.

Valdés, Teresa, and José Olavarría. 1997. Masculinidad/es: Poder y Crisis. Santiago de Chile: Isis Internacional.

Valencia, Antonia Fernández. 2006. La construcción de la identidad desde la perspectiva de género. Iber: Didáctica de las Ciencias Sociales, Geografía e Historia 47: 33-43.

Vavrus, Michael. 2009. Sexuality, Schooling, and Teacher Identity Formation: A Critical Pedagogy for Teacher Education. Teaching and Teacher Education: An International Journal of Research and Studies 25: 383-90. [CrossRef]

Vázquez, Xosé R. Fernández. 2003. Educación e Igualdad de Oportunidades Entre Sexos. Barcelona: ICE, Universitat de Barcelona.

Villarroya, Encarnación, Dolores Corregido, Montserrat Roset, and María Collado. 2003. Repensar la Enseñanza de la Geografía y la Historia: Una Mirada Desde el Género. Available online: http://www.Redined.Mec.Es/Oai/Indexg.Php?Registro=008200420005 (accessed on 16 May 2020).

Villuendas, Ma Dolores, and Angel J. Gordo López. 2003. Relaciones de Género en Psicología y Educación. Madrid: Consejería de Educación y Cultura, Available online: https://dialnet.unirioja.es/servlet/libro?codigo=288387 (accessed on 2 December 2019).

Winslow, Barbara. 2013. Clio in the Curriculum: The State of Women and Women's History in the Middle and High School Curriculum ... and Perhaps a Way Forward. Journal of Women's History 25: 319-32. [CrossRef]

Wittig, Monique. 1992. The Straight Mind and Other Essays. Boston: Bacon Press.

Woyshner, Christine. 2002. Political History as Women's History: Toward a More Inclusive Curriculum. Theory E Research in Social Education 30: 354-80. [CrossRef]

Woyshner, Christine, and Jessica B. Schocker. 2015. Cultural Parallax and Content Analysis: Images of Black Women in High School History Textbooks. Theory and Research in Social Education 43: 441-68. [CrossRef]

Yin, Robert. 2009. Case Study Research: Design and Methods. London: SAGE Publications. 
Article

\title{
Pre-Service Teachers' Critical Digital Literacy Skills and Attitudes to Address Social Problems
}

\author{
Jordi Castellví ${ }^{1, * \mathbb{D}}$, María-Consuelo Díez-Bedmar ${ }^{2}$ and Antoni Santisteban ${ }^{1}$ \\ 1 Department of Language, Literature and Social Sciences Education, Faculty of Education, \\ Autonomous University of Barcelona, Bellaterra, 08193 Cerdanyola del Vallès, Spain; \\ antoni.santisteban@uab.cat \\ 2 Department of Science Education, Faculty of Humanities and Educational Sciences, University of Jaen, \\ 23071 Jaén, Spain; mcdiez@ujaen.es \\ * Correspondence: jordi.castellvi.mata@uab.cat
}

Received: 6 July 2020; Accepted: 27 July 2020; Published: 29 July 2020

check for updates

\begin{abstract}
The emergence and expansion of social networks in the digital age has led to social transformations that have a great impact within the field of education. Teacher-training programs face the challenge of preparing future teachers to critically interpret digital media. They must succeed in this if we are to develop citizens who are well informed and reflective, which then raises the question: Are future teachers critical thinkers? This study took third- and fourth-year students of primary education $(\mathrm{n}=322)$ at five Spanish universities and explored their capacity for constructing critical discourses. It examined how well they can analyze and discuss information from digital media on social problems like poverty, economic crises, social justice, and the media. Its findings reveal that future teachers have difficulty in putting together critical discourses based on information from the Internet on social problems. Those who have doubts, compare, analyze, and reason are the minority.
\end{abstract}

Keywords: critical digital literacy; social problems; pre-service teachers

\section{Introduction}

\subsection{Learning in a Digital Age}

The digital age, with its apparently limitless worldwide social, cultural, and economic exchanges (Pérez-Gómez 2012), has changed the way we interact through the media and how we access information (Bauman 2008). Not only that, it has also influenced all communication, information, and learning areas, whether they are digital or not (Castellví et al. 2020b). Social and digital media have generated reading and writing practices, which points to a cultural change of prime importance (Pérez-Tornero 2011), one which has not been accompanied by an educational change to help in selecting, discriminating, or evaluating the information in the media.

The Internet, thanks to its immediacy and accessibility, has become one of the primary sources of information for young people (Blikstad-Balas 2015; Castellví 2019). However, the information it offers us often reproduces hegemonic narratives and can be lacking in rigor, or even biased or false. On the other hand, digital and social media can play a crucial role in fostering democratic participation, social and civic engagement, and social change (Díez-Gutiérrez and Díaz-Nafría 2018; Kellner and Share 2007) and can be a powerful tool for countering hegemonic narratives.

\subsection{Critical Digital Literacy Skills and Attitudes}

One of the most important authors of critical pedagogy is Paulo Freire. With critical pedagogy, Freire set the basis of what we understand by critical thinking. Freire reconstructed what it means 
to be a teacher, showing that education should not be a technique or a list of steps to follow but a transformative action. Freire and Macedo (2004) also introduced a new meaning for the word "literacy". Freire understood that through literacy, and through developing critical thinking, people can change themselves and change society, in a process of liberation. For Freire, the ability to use the written word is essential to transforming the world, and it makes sense when its learning leads us to this praxis. Thus, according to Freire, literacy would be an attitude, rather than a mere skill.

In the early 1990s, with ICT still in its infancy, Lankshear and McLaren (1993) published a work that for the first time took critical literacy as its central theme. Influenced by Freire's thesis of reading the word to read the world (Freire and Macedo 2004), they tried to respond to the propositions made in the preceding decades regarding the formation of critical thinking, which they saw as overly cognitivist. They argued that critical thinking is not merely a set of skills but also an attitude to information, a way of thinking and living, which should prepare us for action and social transformation.

Critical digital literacy (CDL) is recent as a field of study having emerged from critical literacy and critical media literacy, among other fields. CDL is not only about developing technology or critical thinking skills but is a preparation for living in a digital world. Hence, we consider CDL to be the skills and attitudes needed to search for information, analyze multiple multimodal texts, reflect on information, create narratives and counter-narratives, and act socially on the pursuit of radical democracy and global justice (Castellví 2019; Castellví et al. 2020a; Kellner and Share 2007; McDougall et al. 2018; Santisteban et al. 2020).

\section{Educating Critical Teachers}

\subsection{The Digital World Is Challenging}

The idea put forward by Freire and Macedo (2004) — to read the word and the world in order to produce citizens who are literate and therefore able to act in their society-today takes on a very important meaning.

The impact of platforms like YouTube on adolescents who have just completed their primary education (García-Jiménez et al. 2017), or how young people are seen to react to cultural representations of the resistance through Twitter (Torrego and Gutierrez 2016), confirm the conclusion drawn by Ramírez and González (2016), when they warn that the development of media competence, in all its dimensions, depends on the teachers' flexibility in interpreting the curriculum-an ability that depends, in turn, on the training received.

The cultural changes brought by the digital age place us in a digital world that is challenging for schools. It is a matter of urgency for teachers to be trained in CDL (Garrett et al. 2020; McDougall et al. 2018; Meehan et al. 2015; Santisteban et al. 2020; Schwartz 2001) so that they can design educational interventions and develop alternative curricular materials, going beyond the mere use of technology as a teaching resource and holding texts and narratives up to scrutiny from all angles.

Studies like the one conducted by Alonso et al. (2015) point to a clear deficit in university students' competence with regard to the media environment. On the same note, a University of Stanford study made public in 2016 shows alarming results concerning university students' ability to gauge the credibility of online news (Wineburg et al. 2016). This is worrying, as it reveals that a university education does not seem to succeed in preparing the critical thinking of future teachers to face the digital challenge, something that is vital to forming part of a citizenry that is critical, responsible, and participatory in a democratic society. Teachers should be the first to be trained as critical citizens so that they can, in turn, educate the following generations.

We are convinced that the key to achieving a critical citizenry in the digital age lies in education and in proper teacher training at university. We want them to be ideal readers but also critical readers who read against the text (Janks 2018, p. 96). 


\subsection{A Study Conducted with Pre-Service Teachers}

In this study we analyzed some CDL skills and attitudes shown by primary education undergraduates when interpreting news appearing in the Spanish digital media about sensitive issues in our society, such as poverty, social justice, and how the media influence people's opinions. We used real news items appearing in digital media and dealing with issues that urgently need to be addressed through education.

Comber (2015) claims that poverty and social justice are some of the most important topics to be addressed by critical literacy and should lead to problematizing the class and public texts. CDL can only be developed by dealing with social problems (Berson et al. 2017; Stoddard and Marcus 2017).

We probed students' social representations (Moscovici 1993) concerning these major social problems (Evans and Saxe 1996; Legardez 2003; Pagès and Antoni 2011) and controversial issues (Hess 2008; Ho et al. 2017). We also analyzed their CDL skills and attitudes to see whether they put information in quarantine, check it against other sources, uncover the hegemonic discourses behind the text, and build their own narratives critically.

\section{Research Objectives and Methodology}

This study is part of a research project funded by the Spanish Ministry of Science, Innovation and Universities (I+D EDU2016-80145-P), and involving several Spanish universities, some of whose findings we present in advance.

The main aim of this research is to investigate the skills and attitudes of future teachers in critically analyzing information supplied in digital media: assessing the veracity, reliability, or intent of information sources on social problems; discussing the credibility of certain news and other content that is spread through the media and social networks; and finding the intention and ideology beyond the information to answer the research question: Are future teachers critical thinkers?

\subsection{Participants}

The sample of 322 students consisted of third- and fourth-year students taking a bachelor's degree in primary education between fall 2017 and spring 2018 at five of the universities involved in the research project: University of Jaén; University of Málaga; University Jaume I, in Castellón; Florida Universitaria, in Valencia; and Autonomous University of Barcelona (UAB).

\subsection{Sources and Analysis of Data}

Data were collected from a series of open-ended activities and questions, which were undertaken individually within a period of $45 \mathrm{~min}$ and which invited the students to reflect and reveal to what extent they are critical readers of digital media and how they construct their own narrative about the social problems being dealt with. For every question, students could refer to any type of digital source to verify the information, fill in gaps, or search for new sources that might refute it.

The tool used was an online questionnaire, which allowed us to obtain certain quantitative and qualitative data with the aim of appraising the students' ability to analyze different information items and formulate critical discourses on controversial, value-ridden topics. We analyzed the discourses constructed by the students on the basis of two of the questionnaire activities, which asked them to critically analyze news items from online outlets, the content of which was problematic and needed to be verified and interpreted. In the first activity the students reflected on two news items dealing with poverty and social exclusion in Spain. In the second activity they interpreted a set of emotive, value-ridden news items that were slanted in their presentation and which they could check up on.

In order to analyze the information obtained from the questionnaire, based on the research conducted by Wineburg et al. (2016), we developed a rubric for analyzing the narratives in terms of whether these were critical or not, adopting three categories: beginning, emerging, and mastery. With this rubric, we not only consider students' informational and literacy skills but also their critical 
thinking attitudes (Castellví 2019) to not only read between the lines but also beyond the lines (Gray 1960) uncovering the intention and ideology hidden in the discourse. Using the rubric, we categorize discourses that don't show any of the critical thinking skills and attitudes mentioned above as beginning, discourses that show some of them as emerging, whilst discourses that evidence the mobilization of informational, digital and literacy skills, and attitudes (Castellví 2019) and uncover the ideology hidden in the information are categorized as mastery.

\section{Research Findings}

\subsection{Analysis of the First Activity}

In the first activity (Figure 1) the students were asked to critically analyze two news items on child poverty and its impact on children's education, taking into account that, although the above is the central topic of the items, these actually contained surreptitious advertising for a bank and therefore had hidden commercial interests. The news items the students were given are the following:

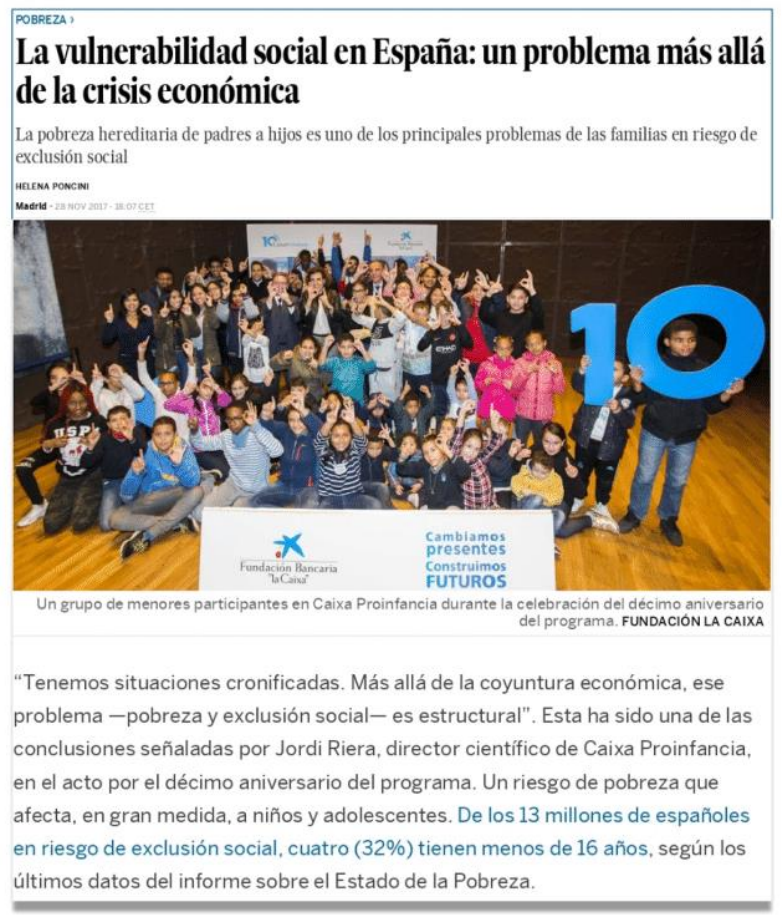

(a)

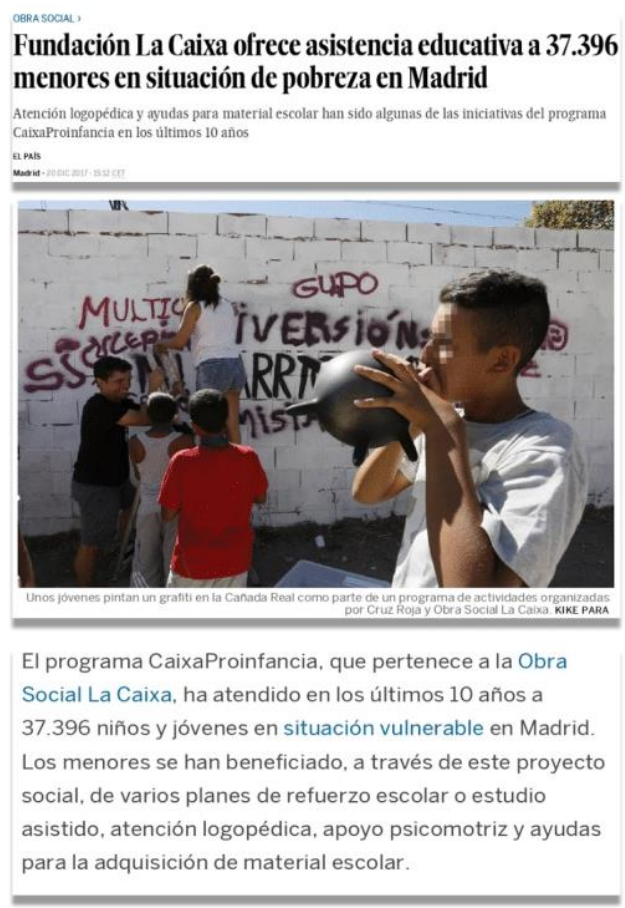

(b)

Figure 1. (a) Social vulnerability in Spain: a problem beyond the economic crisis. (b) La Caixa Foundation offers educative assistance to 37,396 minors in a situation of poverty in Madrid. Pieces of news presented in the activity 1.

Below is a copy of the rubric (Table 1) created to analyze the results of this activity.

Table 1. Rubric utilized to analyze results of activity 1.

\begin{tabular}{ccc}
\hline Beginning & Emerging & Mastery \\
\hline $\begin{array}{c}\text { They describe the pieces of news, } \\
\text { the social issues presented, and the } \\
\text { main protagonists. They don't } \\
\begin{array}{c}\text { specify the interests of the bank } \\
\text { entity or the agenda of } \\
\text { the newspaper. }\end{array}\end{array}$ & $\begin{array}{c}\text { They analyze the poverty as a } \\
\text { social issue and retrieve data from } \\
\text { the pieces of news. They pinpoint } \\
\text { in the discourse. They don't } \\
\text { specify the interests of the bank } \\
\text { entity or the agenda of } \\
\text { the newspaper. }\end{array}$ & $\begin{array}{c}\text { They analyze the poverty as a } \\
\text { social issue and retrieve data from } \\
\text { the pieces of news. They pinpoint } \\
\text { the prominence of the bank entity } \\
\text { in the discourse. They uncover the } \\
\text { interests of the bank entity and the } \\
\text { agenda of the newspaper. }\end{array}$ \\
\hline
\end{tabular}


The results obtained show that the discourses of the primary education undergraduates from the participating universities fall mainly within the category of "beginning". Of the future teachers who took part in the study, $65 \%$ (Figure 2) engaged superficially with the news items and did not discover their hidden intent. In this group can be found arguments like those of Martha and Peter (all names are fictional but reflect the gender identity given in the questionnaire):

Martha: "In the first news item you can see how more and more young people are suffering from social exclusion and poverty. And the second one is about the world we live in, where more and more people are struggling to get by each day on the little they have".

Peter: "The first news item talks about how most child poverty is inherited from the parents, so it's tied up with problems in getting a good education. The second one gives some solutions to put an end to that inherited poverty and educate people so that they can find a better future".

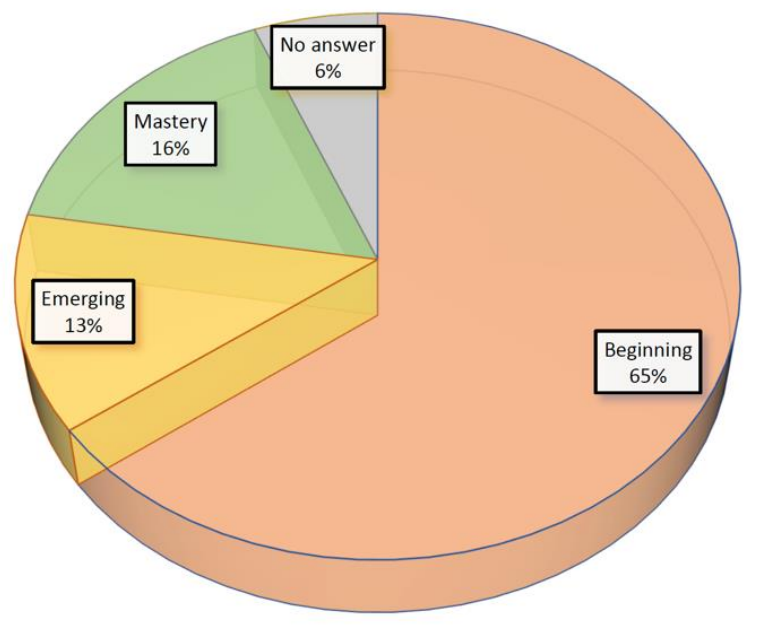

Figure 2. Results obtained from the analysis of activity 1.

Meanwhile, $13 \%$ of the students put together an "emerging" discourse containing some elements of reflective or judicious thinking, but not enough for the discourse to be seen to have the fundamental components of critical thinking. The answers below were given by Jessica and Ann. Jessica sees that the news outlet's focus is not on young people but on the bank, while Ann realizes that the news item tries to put the bank in a good light.

Jessica: "The first item emphasizes the human interest part, as it focuses on children at risk of social exclusion [...]. The second item is more about highlighting the materials and projects that La Caixa has offered to these children. It also gives a complete list of the organizations that have collaborated in this initiative, forgetting about the central characters: the children".

Ann: "My interpretation is that the news item gives some very striking data on poverty in Spain but with the underlying message that La Caixa is closely involved in a project to combat that situation".

Discourses placed in the "mastery" category are also in a minority: 16\% of the total (Figure 2). These display all the elements required for them to be classified as critical discourses, as they spot the advertising intent behind the news and criticize financial entities' role in creating social inequality. They also criticize the news outlet for adopting the format of a news item for what is in fact an advertisement. These elements can be seen in the answer given by Carol: 
Carol: "[...] we should take notice of who is doing the talking: the interviewee in this case is Jordi Riera, scientific director of Caja Proinfancia. [...] Very often, banks give loans or mortgages to families and if they can't repay them, they end up even more in debt or get evicted. Debts can even be inherited by the children. In this news report though, they come out as heroes, saying that the foundation has helped a lot of children in programs dealing with remedial teaching, leisure activities, hygiene, or nutrition, when in fact they're the same banks that cause families to be poor. [...] It sort of looks like the press are mounting an advertising campaign for them, which is really underhand".

The results of the first activity show that the majority of the pre-service teachers who participated in the research did not check the information presented against other sources and made a superficial interpretation of the piece of news. Furthermore, $65 \%$ did not show the skills and attitudes necessary to critically analyze the information presented and discover its intention and the bank's agenda.

\subsection{Analysis of the Second Activity}

In the second activity (Figure 3), the aspiring teachers had to show whether they could read the news from a critical standpoint and cross-check it against other media outlets. The social problem that they addressed in this second activity was not the piece of news they are shown, but the power of the media to manipulate and drive the opinion of people. Aspiring teachers were asked to comment on two successive news items, first on the initial story and then on the follow-up piece, to see if they were capable of changing their minds in light of new information. In the first news story, set in a hotel, some parents are said to have shut their small child in a safe. In the second story, this information is modified, as the parents were not there, and the children were playing hide-and-seek. The idea is for them to revise their initial opinion in light of the new information, if they had not already cross-checked the story by referring to other media outlets or other sources.

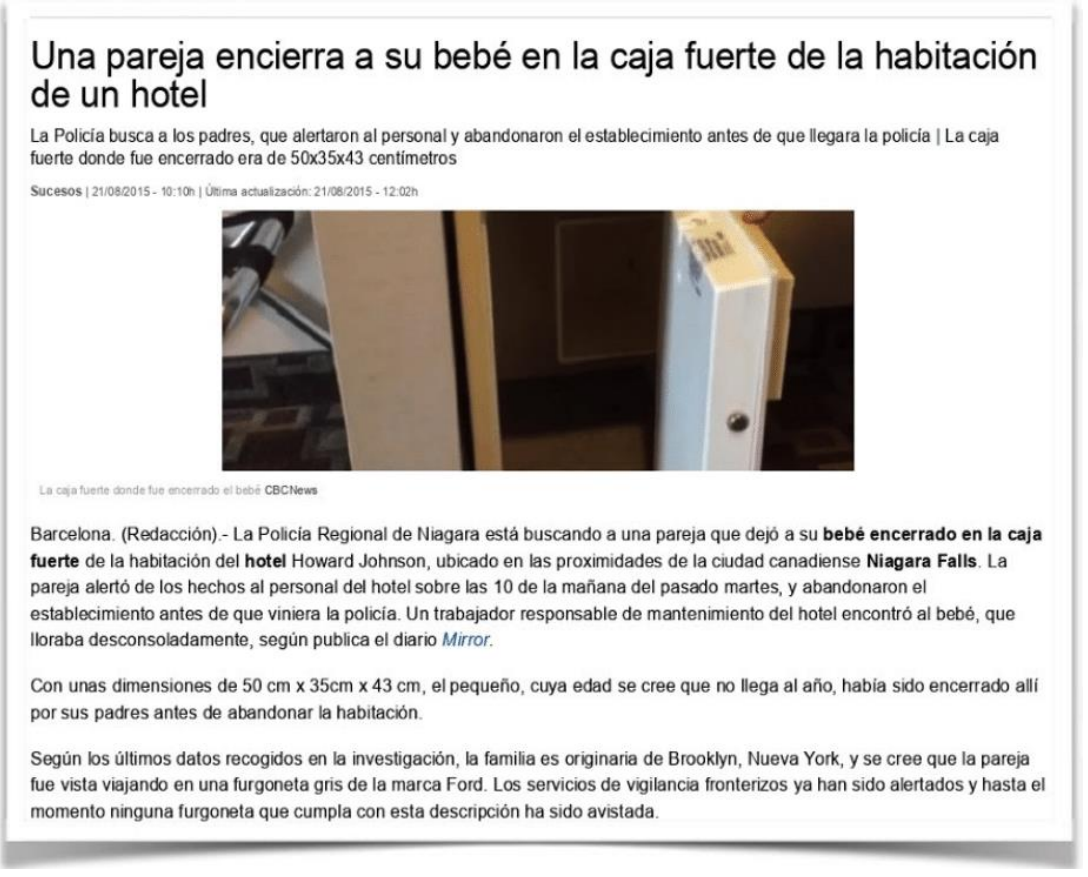

Figure 3. A couple locks their toddler in the safe of their hotel's room. Piece of news presented in the activity 2 .

To be classified as "mastery", it is important for the students to go beyond what the news stories provide and critically appraise not only the participants' attitudes, beginning with the parents, but 
also the particular intentions of the media outlets pushing the story. The news stories presented to the students were the following:

As in the previous activity, a rubric was drawn up to classify the students' answers, as shown in Table 2.

Table 2. Rubric utilized to analyze results of activity 2.

\begin{tabular}{|c|c|c|}
\hline Beginning & Emerging & Mastery \\
\hline $\begin{array}{l}\text { They don't contrast the piece of } \\
\text { news with other information } \\
\text { sources. They describe the pieces } \\
\text { of news, the social issues } \\
\text { presented, and the main } \\
\text { protagonists. They judge the } \\
\text { parents but not the media or they } \\
\text { own uncritical attitude. }\end{array}$ & $\begin{array}{l}\text { They don't contrast the piece of } \\
\text { news with other information } \\
\text { sources. They describe the pieces } \\
\text { of news, the social issues } \\
\text { presented, and the main } \\
\text { protagonists. They judge the } \\
\text { parents and the media, and their } \\
\text { own uncritical attitude. }\end{array}$ & $\begin{array}{l}\text { They contrast the piece of news } \\
\text { with other information sources. } \\
\text { They describe the pieces of news, } \\
\text { the social issues presented, and the } \\
\text { main protagonists. They judge the } \\
\text { parents but also the role of the } \\
\text { media in society. }\end{array}$ \\
\hline
\end{tabular}

The findings of this activity follow the same pattern as those of the first one but deviate slightly. Those who produced discourses placed in the "beginning" category made up 33\% of the total (Figure 4). These discourses are for the most part highly emotive and are not built up from coherent, reasoned argument, even when the students have access to further information that could make them revise their opinions. The information is not called into question but assumed to be valid without consulting online media as suggested from the beginning. The answers given by Frank and Kevin are two examples of this.

Frank: "My opinion is that I hope the baby is taken out of these parents' custody. If it was up to me, life imprisonment".

Kevin: "The decision to have kids is taken together and there are ways to avoid having them, like contraceptives. In some cases, people have a baby and are then shameless enough to have it adopted. Other times, we get a situation like this, which I can only see one solution for: castration for both parties and prison. If a couple are irresponsible enough to have a child they don't want, like I said, you've got adoption. But the kid shouldn't have to die through the fault of thoughtless, selfish parents".

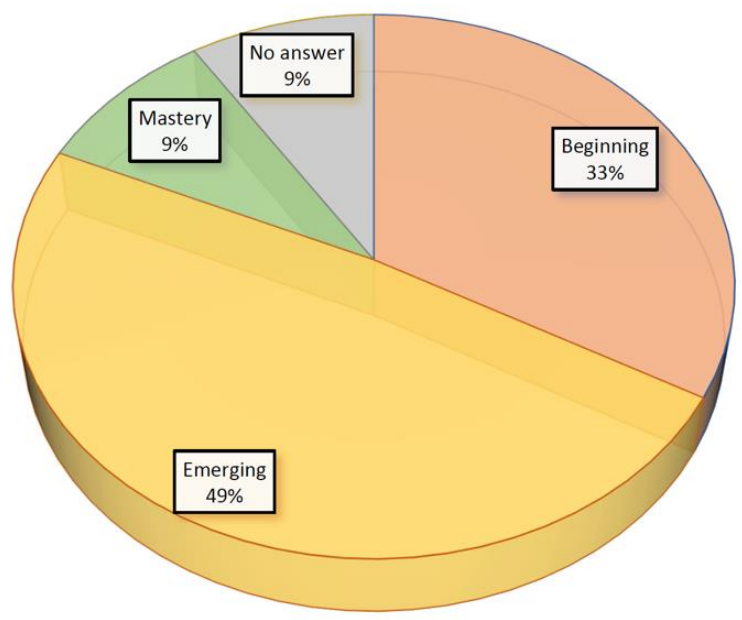

Figure 4. Results obtained from the analysis of activity 2.

Discourses classified as "emerging" made up the majority in this case, reaching $49 \%$ of the total number of discourses in this activity. Below are the answers given by two students, Susan and Adam, 
who at first react viscerally to the news story but, on reading the second story, are able to reflect critically on the media.

Susan (commentary on the first news story): "I think it's twisted for parents to be capable of abandoning the one they should love most in the world like that $[\ldots] "$.

Susan (commentary on the second news story): "The media can be very sensationalist, and they tell stories the way they think they'll sell the best, even if it's far from the truth".

Adam (commentary on the first news story): "I think the parents should get a big fine and go to prison for a while, because there's no excuse for what they've done".

Adam (commentary on the second news story): "I think the media write too fast sometimes, without knowing properly what has happened, I mean, they hear rumors and assume they're right straight away".

Only $9 \%$ of the discourses could be classified as "mastery" or critical: produced by students who query the veracity of the information at all times, cross-checking it and reflecting critically on the influence of the media, on how information is manipulated, and on the importance of cross-checking against other sources. This can be seen in the answer given by Sarah.

Sarah: "They're directly accusing the parents of something really heavy that's not ethical and doesn't make sense to do to anybody, especially your children. They haven't done any research before writing this story and they're making judgements. [...] People should be able to read and learn about what's going on and being talked about in the world, but we should be able to analyze and criticize what we're reading or what we're being told. We should be able to judge what we're being told or at least query it".

The results of the second activity are consistent with the results obtained in the first activity, as $33 \%$ of pre-service teachers did not show skills and attitudes needed to check information and critically analyze the social problem presented. It is remarkable how "beginning" and "emerging" narratives evoke emotions regarding the issue presented. However, the "emerging" ones are capable of reflecting on the importance of checking information and the influence of the media in society in that they are asked to compare the first piece of news that is biased, with the second one that clarifies the case.

\section{Discussion and Conclusions}

When analyzing the students' responses in the two activities, what strikes us most is how low they scored on capacity for critical thinking when dealing with social problems. The results obtained are in line with those of the Stanford History education group (McGrew et al. 2017; Wineburg et al. 2016), whose report goes so far as to call them devastating. The results are also in line with those obtained in other research studies with pre-service teachers (Santisteban et al. 2020) and with secondary school students (Castellví et al. 2020b). These low scores could be attributed to the fact that (1) education, at any level, mostly provides students with uncritical skills that have the appearance of being politically neutral; (2) the spaces of socialization such as the Internet or the media could have bigger impact on people's opinion than formal and non-formal education; (3) political discourses evoke emotions (Castellví et al. 2019), which are powerful tools to spread ideas without making a critical reflection about them.

The data obtained in the two activities point to a very small minority of students formulating critical discourses at the "mastery" level: below $20 \%$ in both activities. This percentage is worrying, especially in light of the fact that these students will have the responsibility of teaching the critical citizenry of the future. If they themselves are not capable of questioning information in a world dominated by multiple digital media, they are even less likely to be able to help their pupils to question power relations and work to promote social justice and democracy. 
Most of the students put together discourses that were placed in the "beginning" category in the first activity, and as many as $65 \%$ were unable to spot a news story with an underlying commercial intent. For the second activity the number was 33\%. These percentages seem very high for students in the second half of their university studies, who should by now be used to cross-checking information to establish its reliability. This leads us to the following questions. How can critical thinking be taught in pre-university education? How should it be taught at university? In this new context it seems appropriate to reconsider the role of future teachers within the education system (Kendall and McDougall 2012) and the objectives of initial training programs.

In the second activity the category with the largest number of students $(49 \%)$ is the "emerging" category, while, in the first activity, $13 \%$ fall into this category. We could initially have expected these students to be well used to using digital resources, interpreting information they can access easily and weighing up the veracity of what appears on the multiple screens they use. But the study's findings indicate, rather, that they do not have these abilities or do not put them into practice.

According to Gutierrez and Tyner (2012), media education in the different stages of education should not be limited to developing a merely instrumental digital competence, neglecting attitudes and values. However, our research suggests that, while attaining technical mastery of the medium, few students show more than a negligible willingness to take a step further and critically interpret information. Our research also shows that there is still much work to be done with university students regarding the social problems at the core of the activities and regarding critical reading of the media, as seen also in other studies (Alonso et al. 2015; Wineburg et al. 2016).

As we see it, beyond the question of whether a particular story is interpreted one way or another, aspiring teachers must take a clear stance on human rights and democratic values. By teaching how to make use of digital resources, we should be producing responsible, cultivated, critical citizens (Area-Moreira and Pessoa 2012), who are fully aware of their social function as teachers. It is clear that teacher-training programs need to be rethought with the aim of incorporating critical media literacy. Additionally, they should include the study of social problems or controversial topics that can call into question how we approach the media and interpret information.

We are convinced of the need for CDL in citizenship education, to prepare citizens for democratic participation. We propose working with social problems, as an essential education tool in today's democracy, to help develop critical thinking (Santisteban 2019). One question we could ask ourselves is whether someone is educated if they are not capable of distinguishing between manipulation and information. We could also ask ourselves whether we can assure the future of democracy without critical, participative, and responsible citizens. These should be our main challenges as teachers.

Author Contributions: Conceptualization, J.C. and A.S.; Data curation, J.C.; Formal analysis, J.C.; Funding acquisition, A.S.; Investigation, J.C., M.-C.D.-B. and A.S.; Methodology, A.S.; Project administration, A.S.; Resources, A.S.; Software, J.C.; Supervision, M.-C.D.-B.; Validation, J.C., M.-C.D.-B. and A.S.; Visualization, J.C.; Writing-original draft, J.C. and M.-C.D.-B.; Writing-review \& editing, J.C. and M.-C.D.-B. All authors have read and agreed to the published version of the manuscript.

Funding: This publication is part of the R \& D Project 'Teach and learn to interpret contemporary problems and conflicts. What do the Social Sciences contribute to the formation of a critical global citizenship?', funded by the Spanish Ministry of Science, Innovation and Universities (EDU2016-80145-P), whose main researcher is Professor Antoni Santisteban (Autonomous University of Barcelona).

Conflicts of Interest: The authors declare no conflict of interest.

\section{References}

Alonso, Alejandro Buitrago, Eva Navarro Martínez, and Agustín García Matilla. 2015. Communication, Education and Society in a Digital Context. A Pioneering Experience of Media Literacy at the Spanish University. In Agents and Voices A Panorama of Media Education in Brazil, Portugal and Spain. Edited by Elea Ilana. Gothenburg: International Clearinghouse on Children, Youth and Media at Nordicom, University of Gothenburg, pp. 269-76. 
Area-Moreira, Manuel, and Teresa Pessoa. 2012. From Solid to Liquid: New Literacies to the Cultural Changes of Web 2.0. [De lo sólido a lo líquido: Las nuevas alfabetizaciones ante los cambios culturales de la Web 2.0]. Comunicar 38: 13-20. [CrossRef]

Bauman, Zygmunt. 2008. Los Retos de la Educación en la Modernidad Líquida. Barcelona: Gedisa.

Berson, Ilene R., Michael J. Berson, Danielle V. Dennis, and Rebecca Lovering Powell. 2017. Leveraging Literacy: Research on Critical Reading in the Social Studies. In The Wiley Handbook of Social Studies Research. Edited by McGlinn Meghan and Mason Cheryl. New York: Wiley-Blackwell, pp. 414-39.

Blikstad-Balas, Marte. 2015. "You get what you need": A study of students' attitudes towards using Wikipedia when doing school assignments. Scandinavian Journal of Educational Research 60: 1-15. [CrossRef]

Castellví, Jordi. 2019. Literacitat Crítica Digital en els Estudis Socials. Estudis de Cas en Educació Primària (Critical Digital Literacy in Social Studies. Case Studies in Elementary School). Doctoral dissertation, Autonomous University of Barcelona, Bellaterra, Spain.

Castellví, Jordi, Massip Mariona, and Pagès Joan. 2019. Emociones y pensamiento crítico en la era digital: Un estudio con alumnado de formación inicial. Revista de Investigación en Didáctica de las Ciencias Sociales 5: $23-41$.

Castellví, Jordi, Tosar Breogán, and Andreu Mercè. 2020a. La lectura crítica de los medios digitales. Íber. Didáctica de las Ciencias Sociales, Geografía e Historia 99: 7-14.

Castellví, Jordi, Tosar Breogán, and Santisteban Antoni. 2020b. Young people confronting the challenge of reading and interpreting a digital world. Bellaterra Journal of Teaching $\mathcal{E}$ Learning Language $\mathcal{E}$ Literature. in press.

Comber, Barbara. 2015. Critical literacy and social justice. Journal of Adolescent \& Adult Literacy 58: 362-67.

Díez-Gutiérrez, Enrique, and José-María Díaz-Nafría. 2018. Ubiquitous learning ecologies for a critical cybercitizenship. [Ecologías de aprendizaje ubicuo para la ciberciudadanía crítica]. Comunicar 54: 49-58. [CrossRef]

Evans, Ronald W., and David W. Saxe. 1996. Handbook on Teaching Social Issues. Washington: National Council for the Social Studies.

Freire, Paulo, and Donald Macedo. 2004. Literacy: Reading the Word and the World. London: Routledge.

García-Jiménez, Antonio, Manuel Montes, and Juan Menor. 2017. Condiciones de vulnerabilidad y apropiación del ciberespacio en la adolescencia. In Del Verbo al Bit. Edited by Herrero Francisco Javier and Mateos Concha. Tenerife: Sociedad Latina de Comunicación Social, pp. 570-86.

Garrett, H. James, Mardi Schmeichel, Joseph McAnulty, and Sonia Janis. 2020. Teaching and learning news media in politically unsettled times. Pedagogies: An International Journal 15: 1-18. [CrossRef]

Gray, William S. 1960. The major aspects of reading. In Sequential Development of Reading Abilities. Edited by Mansfield Helen. Chicago: Chicago University Press, pp. 8-24.

Gutierrez, Alfonso, and Kathleen Tyner. 2012. Media Education, Media Literacy and Digital Competence. [Educación para los medios, alfabetización mediática y competencia digital]. Comunicar 38: 31-39. [CrossRef]

Hess, Diana. 2008. Controversial Issues in Democratic Discourse. In Handbook of Research in Social Studies Education. Edited by Levstik Linda and Tyson Cynthia. New York: Routledge, pp. 124-36.

Ho, Li-Ching, Paula McAvoy, Diana Hess, and Brian Gibbs. 2017. Teaching and Learning about Controversial Issues and Topics in the Social Studies: A Review of the Research. In The Wiley Handbook of Social Studies Research. Edited by McGlinn Meghan and Mason Cheryl. New York: Wiley-Blackwell, pp. 321-35.

Janks, Hilary. 2018. Text, Identities, and Ethics: Critical Literacy in a Post-Thruth World. Journal of Adolescent $\mathcal{E}$ Adult Literacy 62: 95-99.

Kellner, Douglas, and Jeff Share. 2007. Critical media literacy is not an option. Learning Inquiry 1: 59-69. [CrossRef]

Kendall, Alex, and Julian McDougall. 2012. Critical Media Literacy after the Media. [Alfabetización mediática crítica en la postmodernidad]. Comunicar 38: 21-29. [CrossRef]

Lankshear, Colin, and Peter McLaren. 1993. Critical Literacy. Politics, Praxis, and the Postmodern. New York: State University of New York Press.

Legardez, Alain. 2003. L'enseignement des questions sociales et historiques, socialement vives. Le Cartable de Clio 3: $245-53$.

McDougall, Julian, Marketa Zezulkova, Barry Van Driel, and Dalibor Sternadel. 2018. Teaching media literacy in Europe: Evidence of effective school practices in primary and secondary education. In NESET II Report. Luxembourg: Publications Office of the European Union. [CrossRef]

McGrew, Sarah, Teresa Ortega, Joel Breakstone, and Sam Wineburg. 2017. The challenge that's bigger than fake news: Civic reasoning in a social media environment. American Educator 41: 4-11. 
Meehan, Jessica, Brandi Ray, Amanda Walker, Sunny Wells, and Gretchen Schwarz. 2015. Media Literacy in Teacher Education: A Good Fit across the Curriculum. Journal of Media Literacy Education 7: 81-86.

Moscovici, Serge. 1993. Psicología Social. Barcelona: Paidós.

Pagès, Joan, and Santisteban Antoni. 2011. Les qüestions socialment vives i l'ensenyament de les ciències socials. Barcelona: Servei de Publicacions de la Universitat Autònoma de Barcelona.

Pérez-Gómez, Ángel. 2012. Educarse en la era Digital. Madrid: Morata.

Pérez-Tornero, José Manuel. 2011. El aprendizaje de la lectura comprensiva y crítica. Aula de Innovación Educativa 200: 55-59.

Ramírez, Antonio, and Natalia González. 2016. Media Competence of Teachers and Students of Compulsory Education in Spain. [Competencia mediática del profesorado y del alumnado de educación obligatoria en España]. Comunicar 49: 49-58. [CrossRef]

Santisteban, Antoni. 2019. La enseñanza de las Ciencias Sociales a partir de problemas sociales o temas controvertidos: Estado de la cuestión y resultados de una investigación. El Futuro del Pasado 10: 57-79. [CrossRef]

Santisteban, Antoni, Díez-Bedmar María Consuelo, and Castellví Jordi. 2020. Critical digital literacy of future teachers in the Twitter Age. Culture E Education 32: 1-28. [CrossRef]

Schwartz, Gretchen. 2001. Literacy Expanded: The Role of Media Literacy in Teacher Education. Teacher Education Quarterly 28: 111-19.

Stoddard, Jeremy, and Alan S. Marcus. 2017. Media and Social Studies Education. In The Wiley Handbook of Social Studies Research. Edited by McGlinn Meghan and Mason Cheryl. New York: Wiley-Blackwell, pp. 477-98.

Torrego, Alba, and Alfonso Gutierrez. 2016. Watching and Tweeting: Youngsters' Responses to Media Representations of Resistance. [Ver y tuitear: Reacciones de los jóvenes ante la representación mediática de la resistencia]. Comunicar 47: 9-17. [CrossRef]

Wineburg, Sam, Sarah McGrew, Joel Breakstone, and Teresa Ortega. 2016. Evaluating Information: The Cornerstone of Civic Online Reasoning. Stanford: Stanford Digital Repository.

(C) 2020 by the authors. Licensee MDPI, Basel, Switzerland. This article is an open access article distributed under the terms and conditions of the Creative Commons Attribution (CC BY) license (http://creativecommons.org/licenses/by/4.0/). 

Article

\title{
Global Citizenship and Analysis of Social Facts: Results of a Study with Pre-Service Teachers
}

\author{
Gustavo González-Valencia ${ }^{1}{ }^{(\mathbb{D}}$, María Ballbé ${ }^{1}$ and Delfín Ortega-Sánchez ${ }^{2, * \mathbb{C}}$ \\ 1 Departament of Language, Literature and Social Science Education, Faculty of Education, \\ University Autonomous of Barcelona, 08193 Bellaterra (Cerdanyola del Vallès), Spain; \\ gustavo.gonzalez@uab.cat (G.G.-V.); maria.ballbe@uab.cat (M.B.) \\ 2 Department of Specific Didactics, Faculty of Education, University of Burgos, 09001 Burgos, Spain \\ * Correspondence: dosanchez@ubu.es
}

Received: 2 April 2020; Accepted: 27 April 2020; Published: 30 April 2020

\begin{abstract}
This article outlines how the dimensions of global citizenship education (GCE) are reflected in future secondary school teachers' analysis of news items. The question that guided the research was: When analysing a news item with global implications, do teachers in training use the dimensions of the critical global citizenship education model and which critical literacy achieve? The study used a mixed methodology. Content analysis was used to analyse the information, specifically the use of codes through descriptive and inferential statistics. The findings show that the majority of future secondary school teachers tend to take a socially committed perspective, while they take a critical stance or mobilise for social justice action to a lesser extent.
\end{abstract}

Keywords: social studies; controversial issues; critical perspective; teacher education; globalization

\section{Introduction}

In today's world, people tend to understand that local and global social facts and problems are increasingly interrelated. This is a reflection of the economic, political and cultural globalisation that the world has experienced in the past three decades (Pak 2013; Pak and Lee 2013; Stromquist and Monkman 2014). Globalisation has been magnified by the presence of information technologies, especially the Internet, which, according to Castells (2005), has contributed to shaping an increasingly interconnected world, where the media bear a direct influence on the way society and citizenship are understood (Santisteban and González-Valencia 2013).

The globalisation process can be explained by different theories. The framework review devised by Sklair (1999), Spring (2004) and Torres (2015) presents four main approaches to help us understand globalisation. They are neoliberalism, global culture, global systems and post-colonialist interpretations. In turn, Shultz (2007) cites three: The neoliberal approach, the radical approach and the transformative approach. These approaches show that taking a stance on globalisation opens up considerations when researching and developing educational proposals on global citizenship (Stromquist 2009).

Globalisation in all its dimensions has led to a reconsideration of the concepts of citizen and citizenship under the scheme of the nation-state. The theoretical frameworks developed by Arthur et al. (2008), Delanty (1997), Faulks (2000), Isin and Turner (2002), Janoski and Gran (2002), Kymlicka and Norman (1994), Tully (2014), Reysen and Katzarska-Miller (2013) and Gun Chung and Park (2016) reveal that citizenship goes beyond legal recognition; after all, holding an official document that certifies a person is a "citizen" does not mean that this person exercises the duties and rights associated with citizenship. Instead, citizenship transcends legal recognition and should be placed within the sphere of the quest for moral imperatives that mobilise people to seek a better life for the community; a "citizen is one who participates directly in public deliberations and decisions" (Barber 1984, in Cortina 2003, p. 43) 
and who tries "to construct a good polis, seeking the common good in their political participation" (Cortina 2003, p. 48), which nowadays is between the local and global scale.

According to Broomley (2009), Delanty (1997) and Rauner (1999), citizenship can be understood in the frame of relation to national and post-national, such as supranational, international, global and virtual, planetary, global or global-local (glocal) entities (Broomley 2009). The blurring of borders and the establishment of supranational governing bodies (OECD, European Union, NAFTA, Pacific alliance, Mercosur, etc.) which bear an increasing influence on the lives of people, societies and states have played a key role in the reconfiguration of the concept of citizenship. One definition that serves as a general framework for understanding global citizenship was proposed by UNESCO (2018), which suggests that it refers to the sense of belonging to a larger community and a shared humanity where there is political, economic, social and cultural interdependence in connection with the local, national and global levels.

The progress of globalisation in the past three decades has also shown its less positive side, partly due to the excessive centrality of the economic dimension at the expense of the political dimension, which has generated situations like an increase in poverty, inequality and pollution in the world. This has its correlate, that may a positive, in the emergence and growth of international organisations which work on these matters, such as Save the Children, Oxfam Intermón, Amnesty International, Human Rights Watch, Transparency International and Greenpeace, which can be viewed as ways in which global citizenship materialises, opening new possibilities and scenarios of action for citizens on a global scale, and reflect the link between citizenship and globalizations below global citizenship. In the opinion of Tully (2014, p. 4), when trying to connect citizenship and globalisation, "we are already thrown into this remarkably complex inherited field of contested languages, activities, institutions, processes and the environs in which they take place. This conjoint field is the problematization of global citizenship: the way that formerly disparate activities, institutions and processes have been gathered together under the rubric of 'global citizenship', become the site of contestation in practice and formulated as a problem in research, policy and theory, and to which diverse solutions are presented and debated".

Even though the notion of citizenship is associated with the nation-state, "new forms of citizenship are growing in the face of globalisation. This means that new forms of education need to be developed. It is unlikely that new forms of education will be achieved by attempting to bolt very different formulations together" (Davies et al. 2005, p. 83). Education, and specifically teaching the social sciences, should contribute explicitly to achieving and developing this (Goren and Yemini 2017a), because globalization's effects, the social, cultural, political and economic changes, "hold special significance in educational settings, where preparing students for a global world has come to play an important role in citizenship education" (Szelényi and Rhoads 2007, p. 25). They are forcing schools and teachers to take an increasingly active role. This aligns with the fact that the quality of education means that students develop "the skills, values and attitudes that enable citizens to lead healthy and fulfilled lives, make informed decisions, and respond to local and global challenges through sustainable development education and global citizenship education, as well as human rights education" (UNESCO 2018, p. 1).

The literature review revealed that there are studies which inquire into the discourses on global citizenship education in future teachers (Yemini 2017; Yemini et al. 2019; Kim 2019), the purposes of teaching it (Bruce et al. 2019), the efficacy of teacher training programmes on global citizenship (Kopish 2016; Yang et al. 2017), the assessment of teaching proposals or methodologies ( $\mathrm{O}^{\prime}$ Meara et al. 2018), the influence of global education on viewing oneself as a global citizen (Larsen and Searle 2017) and specifically in working teachers (Goren and Yemini 2016; Goren et al. 2019; Çolak et al. 2019; Leduc 2013). They all concur on the importance of including global citizenship education in teacher training programmes in different ways.

The study by Kim (2019) shows that there is little room for teaching and discussing global citizenship education and his teaching in teacher training programmes. This kind of approach 
motivated the study by Tarozzi and Mallon (2019) on how teacher training programmes in universities in four countries (Austria, Ireland, Italy and the Czech Republic) address GCE. This study found that the ways global citizenship education is understood and taught reflect the cultural and political contexts of each country, and that they take shape in three typologies: Content-centred, values-centred and competence-centred.

In this regard, global citizenship education is viewed as a way people can gain a broader and better understanding of the interrelationship between citizenship, politics, democracy and the globalisation process, which leads them to understand the political, economic, cultural, social and environmental implications (O'Meara et al. 2018; Bruce et al. 2019). From these theorical frames, we proposed a research question: When analysing a news item with global implications, do teachers in training use the dimensions of the critical global citizenship education model and which critical literacy achieve?

This project is based on the assumption that future teachers forge connections between theoretical notions and the analysis of practical cases which entails connecting the local and global scales. In this perspective, it identifies with what Tarozzi and Inguaggiato (2018), Goren and Yemini (2017b) and UNESCO (2015) suggest when they state that teacher training plays a critical role in implementing GCE: "Teachers and educators recognise the importance of GCE; however, they often feel trapped between curricular goals encouraging its incorporation in the classroom and cultural norms of nationalism or lack of practical resources that hinder their ability to actually teach it" (Goren and Yemini 2017b, p. 179).

\section{Global Citizenship Education}

In the past 15 years, much has been written on global citizenship education (Davies et al. 2005; Szelényi and Rhoads 2007; Oxley and Morris 2013; Dill 2013; Goren et al. 2019; Sant and González-Valencia 2018; Reysen and Katzarska-Miller 2013; Rapoport 2009; Gun Chung and Park 2016; Sant 2018). After reviewing several proposed definitions of GCE, we can note that the combination of the concepts of "globalisation" and "citizenship" in the "global citizenship" construct merges the meanings of each term and generates new questions on "global citizenship" that emerge with even greater complexity, from combinations that are reflected in theorical proposals and social significance (Tully 2014).

The UNESCO institution defines GCE as, "essentially, GCED addresses three core conceptual dimensions of learning: for education to be transformative, knowledge (cognitive domain) must touch the heart (socio-emotional domain) and turn into action to bring about positive change (behavioural domain). This framework emphasizes an education that fulfils individual and national aspirations and thus ensures the well-being of all humanity and the global community at large" (UNESCO 2018, p. 2).

The definition put forth by UNESCO, an institution which is part of the web of global governance, stresses the aspects more closely related to the psychology of learning, while covering the political and critical dimension or post-colonialist discourses to a lesser extent (Andreotti 2006). One approach more closely associated with a critical dimension of global citizenship education is by Reysen and Katzarska-Miller (2013, p. 858), who understand as "awareness, caring, and embracing cultural diversity while promoting social justice and sustainability, coupled with a sense of responsibility to act. Prior theory and research suggest that being aware of one's connection with others in the world (global awareness) and embedded in settings that value global citizenship (normative environment) lead to greater identification with global citizens (i.e., prosocial values and behaviors)".

This definition of GCE puts aspects like social justice, diversity and awareness, which are essential in a critical approach, at the core. In the midst of the proliferation of definitions of GC and GCE, Pak (2013), Dill (2013) and Stromquist (2009) suggest that, even though there is no consensus, it is essential to develop greater global awareness. Following the ideas of Dill (2013, p. 50): “The global consciousness element of global citizenship ... creates lofty moral expectations: it consists of an awareness of other perspectives, a single humanity as the primary level of community, and a moral conscience to act for the good of the world. The global citizen in this discourse is a moral ideal, a vision 
of a person who thinks and acts about the world in specific ways: as a universal community without boundaries whose members care for each other and the planet".

In the review of the frameworks of global citizenship (Oxley and Morris 2013; Stromquist 2009), the notion emerges that global citizenship can be classified as to whether it represents civil, civic or political notions of citizenship. Stromquist (2009) identifies three main approaches: Social, political and economic. In the opinion of Oxley and Morris (2013), there are social, political, economic, cultural, environmental and moral perspectives. These interpretations come from the theory of world culture, social and critical citizenship and global systems framed in post-colonialist theories of globalisation (Andreotti 2006). From this vantage point, UNESCO's definitions ignore these aspects or relegate them to the background, and Tawil (2013, p. 5) suggests that they can be classified as a soft approach: "In 'softer' approaches, the starting point for global dimensions of citizenship education is of a more moral variety based on the notion of a common humanity and a global or world ethic. In more 'critical' approaches, the ethical starting point is the concept of social justice as farmed by the international normative instruments of human rights".

This research took Oxley and Morris's definition of GCE, which posits "the normative and empirically grounded conceptions of GC in terms of their ideological underpinnings" (2013, p. 305). Therefore, we understand that "critical conceptions of GC tend to promote a form of 'counter-hegemony', emphasising the deconstruction of oppressive global structures, and are also connected to what Dei (2008, p. 479) describes as 'a politics of social transformation'" (Oxley and Morris 2013, p. 313). Global citizenship will be possible inasmuch as people can identify and question the ideological dimension of events and stories on a local and global scale (Tosar and Santisteban 2016) with local repercussions, such as the rise of nationalism or populism. This way of citizen's training in understanding should entail grasping that there are individuals and human groups with diverse ways of thinking, ideologies and interests, whose imperative is to reach agreements, decide on a social organisation and mechanisms to solve conflicts, and recognise and value ethnic, cultural or religious diversity.

In this perspective, GCE is a type of education that seeks to train citizens who recognise, understand and are willing to think and act globally. This perspective transcends the nation-state and is geared towards the quest for the highest moral imperatives (Cortina 2003), that is, the construction of social justice on a global scale (Torres 2017; Davies 2006). To achieve this, when analysing a news item, people must consider historical, geographic, political, legal, sociological, anthropological, economic and legal factors. This is related to the idea that GCE "empowers individuals: to reflect critically on the legacies and processes of their cultures and contexts, to imagine different futures and to take responsibility for their decisions and actions" (Andreotti 2006, p. 169). We identify with the idea of critical citizenship education in this perspective (Andreotti 2006; Tully 2014).

An approach to GCE, in the opinion of Tarozzi and Inguaggiato (2018) and Scheunpflug and Asbrand (2006), geared at social justice is considered a suitable framework for analysing actions in educational settings because it enables us to see how its core concepts appear and how they are related to other aspects surrounding education in general. In their words, "this conception of GCE echoes one of the roots of GCE theoretical framework which is Freirean pedagogy" (Tarozzi and Inguaggiato 2018, p. 122) because, as Freire posited, "for a more equitable and just society, at the heart of development education' objectives, people must be able to critically reflect on the world, challenge assumptions that create oppression and reconstruct understanding based on this collaborative inquiry" (Freire 1970, p. 53).

The project theoretical framework approach developed is related to Davies (2006, p. 6), who says that "what seems to happen with global citizenship education is a confirmation of the direct concern with social justice and not just the more minimalist interpretations of global education which are about 'international awareness' or being a more rounded person". 


\section{Teaching the Social Sciences and Global Citizenship Education}

Teaching the social sciences, history and geography from a critical, interdisciplinary perspective helps people understand and participate in solving social facts or problems that are increasingly global and affect citizens in different ways (Pagès and Santisteban 2014; Anguera et al. 2018; Torres 2009, 2017), and it helps students gain a better understanding of the relationship between citizenship and globalisation (Rapoport 2009). In this perspective, the project made a theoretical proposal to analyse facts and issues under global citizenship. The criteria for develop in this proposal was a social science discourse with more presence in secondary education and high school. In Spain the Royal Decree 1105 (Government of Spain 2015) established that history and geography are compulsory areas, but it is possible to find references to other humanities and social sciences such as political science, philosophy, sociology, etc.

By examining what each of them can contribute to understanding news items, the following synthesis was reached (Figure 1):

- History enables students to learn about events in time with attributes like the simultaneity or contemporaneity of events.

- Geography enables students to learn about space, territory and people's interdependence with them.

- Political science enables students to grasp the notions of power, governing systems and political organisation (both national and international).

- Sociology enables students to learn about how societies are organised and work.

- Anthropology enables students to study processes of cultural construction and identity in diverse contexts.

- Economics enables students to gain basic knowledge of resources and wealth and their local and global distribution.

- Ethical factors shape the frameworks that enable students to distinguish between what is just or unjust.

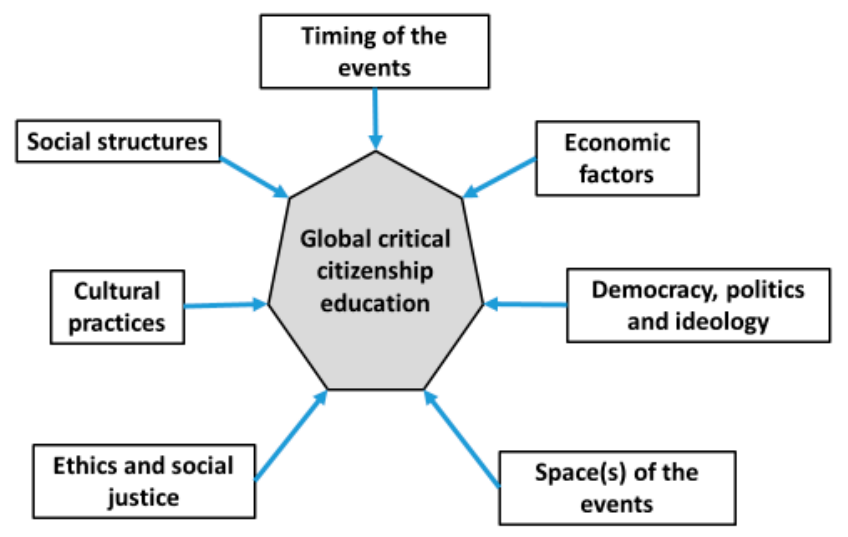

Figure 1. Dimensions of critical global citizenship education. Source: Authors.

This way of understanding the interaction between GCE and the curriculum has referents in different authors' approaches (Andreotti 2006; Shultz 2007; Oxley and Morris 2013) and provided the data analysis with a teleological and conceptual structure based on the assumption that the news items are analysed through the interaction of different sciences or disciplines, with which causal or multi-causal explanations can be constructed (O'Meara et al. 2018). This enabled the research team to trace the global dimension in the responses of the participants, and can answer the research question: When analysing a news item with global implications, do teachers in training use the dimensions of the critical global citizenship education model and which critical literacy achieve? 


\section{Research Methodology}

Participants were selected through convenience sampling (Argibay 2009), based on the ability of the research group to access the target population and its adjustment to the research objectives (Hernández et al. 2010). This type of sampling consists of the self-selection of the sample units without specifying the universe from which they are extracted, according to their possibilities of access (Scribano 2007), and in applying criteria of inclusion-exclusion criteria. The selection criteria for the participating institutions was their active participation in the research project EDU2016-80145-P, financed by the Spanish Government.

The information was obtained from pre-service teachers $(n=53)$ enrolled in a teacher training programme for future secondary school and baccalaureate teachers at universities in two autonomous communities in Spain during academic year 2018-2019 (University 1 (Autonomous University of Barcelona; $\mathrm{UAB})=28$, University 2 (University of Málaga; UMA) $=25$ ). This sample is considered representative in the context of the objectives of this project and the university degree selected (Master's Degree in Secondary Education Teaching). The information was collected via a questionnaire in which the students were given a series of cases constructed based on the theoretical framework, which they had to analyse and then share their opinions on. For data collection in this study, because of its controversial nature, one of the cases was selected, which included a single open question: Interpret the image critically according to the people who appear (Figures 2 and 3).

\section{Research on the Social Representations of university students in initial teacher training \\ CG Group: Global citizenship, radical humanism and invisibles}

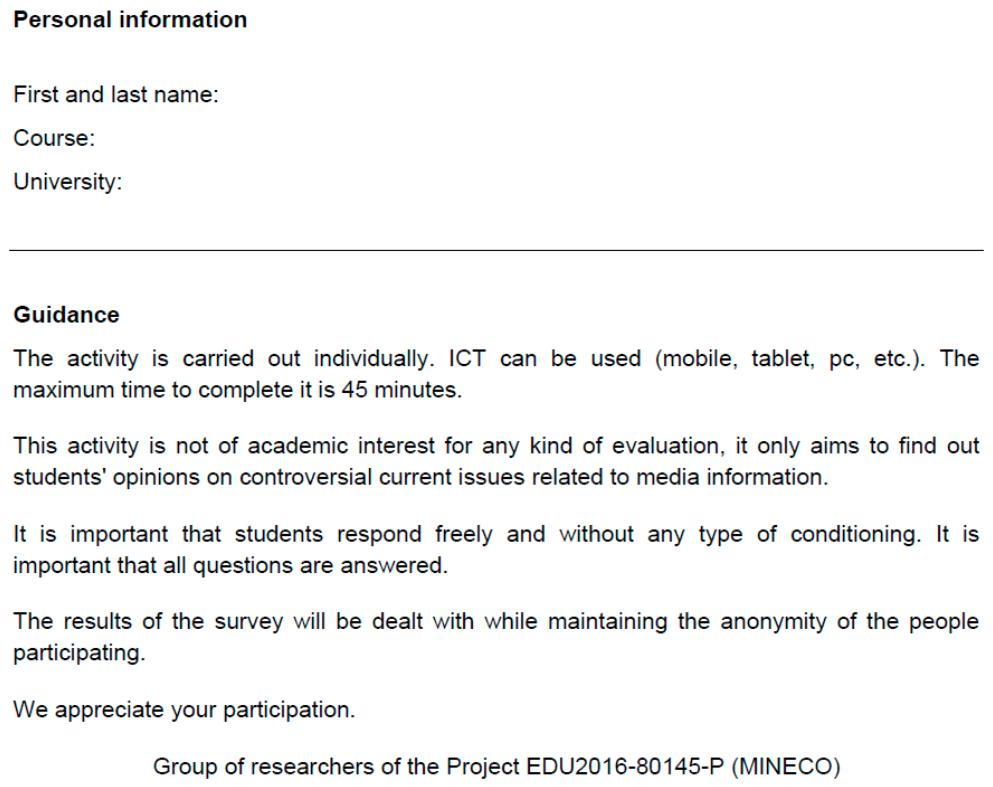

Figure 2. Implementation guidance. 
Activity 1. Take a look at the following picture taken on 7 July 2017 in Hamburg City (Germany) during an international policy meeting, the G20 summit, composed of the world's largest economies and the European Union.

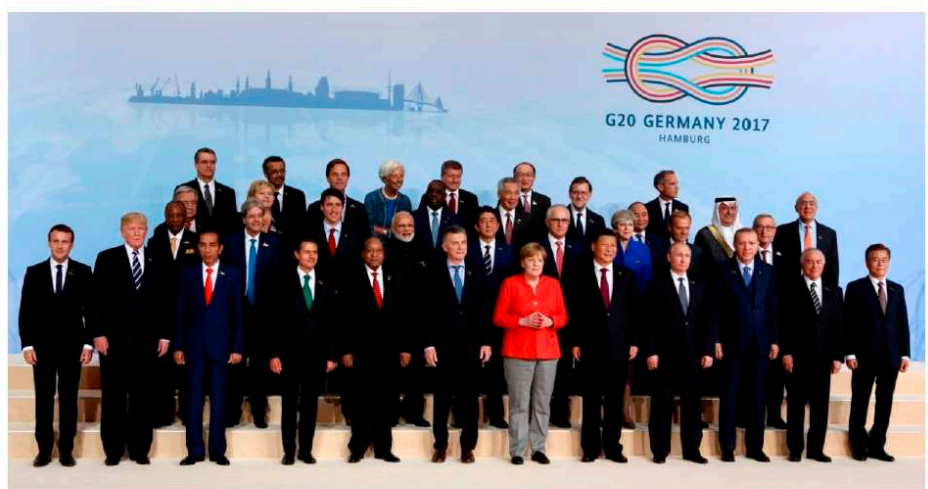

- Interprets the image critically according to the people who appear.

Figure 3. Activity.

The core case, which explicitly represented the relationship between the local and the global, was a photograph of the G20 meeting held on 7 July 2017 in the city of Hamburg (Germany). According to Santisteban (2019), the case entails a controversial factor, because of the global repercussions of these kind the meetings, the small presence of women, cultural practices (dress-colours and style), etc.

For the discursive analysis of the texts generated, a quantitative content analysis was used, through the application of a category system, built from the seven established dimensions (Figure 1), and three levels of literacy: Description, analysis and relation, and interpretation, relation and proposal for social action. Considering the results obtained in didactic research in the field of Spanish teacher training, and in the critical analysis of the official curriculum and curricular materials (Ortega-Sánchez 2017; Ortega-Sánchez and Pagès 2017), the study aims to identify what levels of literacy the future teacher has acquired and is developing in the comprehension/decoding of textual and iconographic speeches of a social nature. To this end, the three levels mentioned are related to three types of literacy: Literal literacy, inferential literacy and critical literacy, oriented to the development of social thinking skills (critical and creative), and to committed and responsible intervention in social reality (Santisteban 2015). This analysis combined the collection, uniform coding, categorization and descriptive and interpretative analysis of qualitative data (manifest content), with quantitative data, obtained on the basis of the former through the ad hoc construction of a dimensional scale classifying the units of analysis (student discourses).

Descriptive and inferential statistical analyses were performed on the texts based on the frequencies and literacy practices revealed by the students and the presence/absence and textual density of the theoretical attributes of the conceptual model proposed (Bardin 2002; Krippendorff 1990).

The data obtained were transcribed and organised into a matrix to be analysed (Miles et al. 2014). This analysis took shape in thematic coding (Flick 2012; Schreier 2014). The codes were defined based on the theoretical approach, and they were: Timing of the events; economic factors; democracy; politics and ideology; space(s) of the events; ethics and social justice; cultural practices; and social structures. In the analysis of the responses, we identified whether or not there was a reference to the dimensions; if there was, it was assigned one point, while the absence of any reference was assigned zero. If more than one reference to each code appeared, they were scored with the number of times it appeared. This enabled us to identify the frequency with which the dimensions of GCE appeared. The numerical coding and thematic categorization of the qualitative data are reproduced in Figures 4 and 5. 


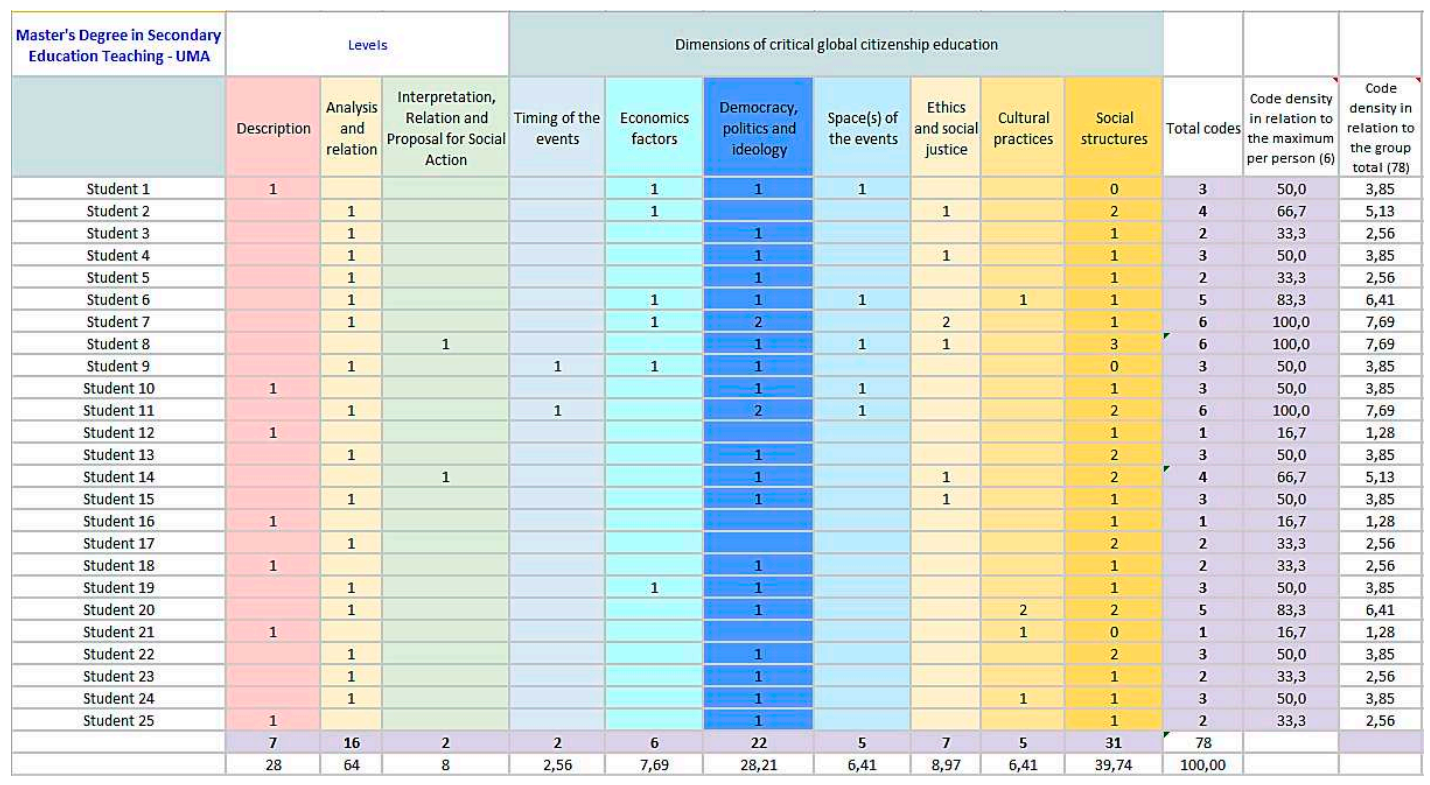

Figure 4. Data emptying matrix-University of Málaga (UMA).

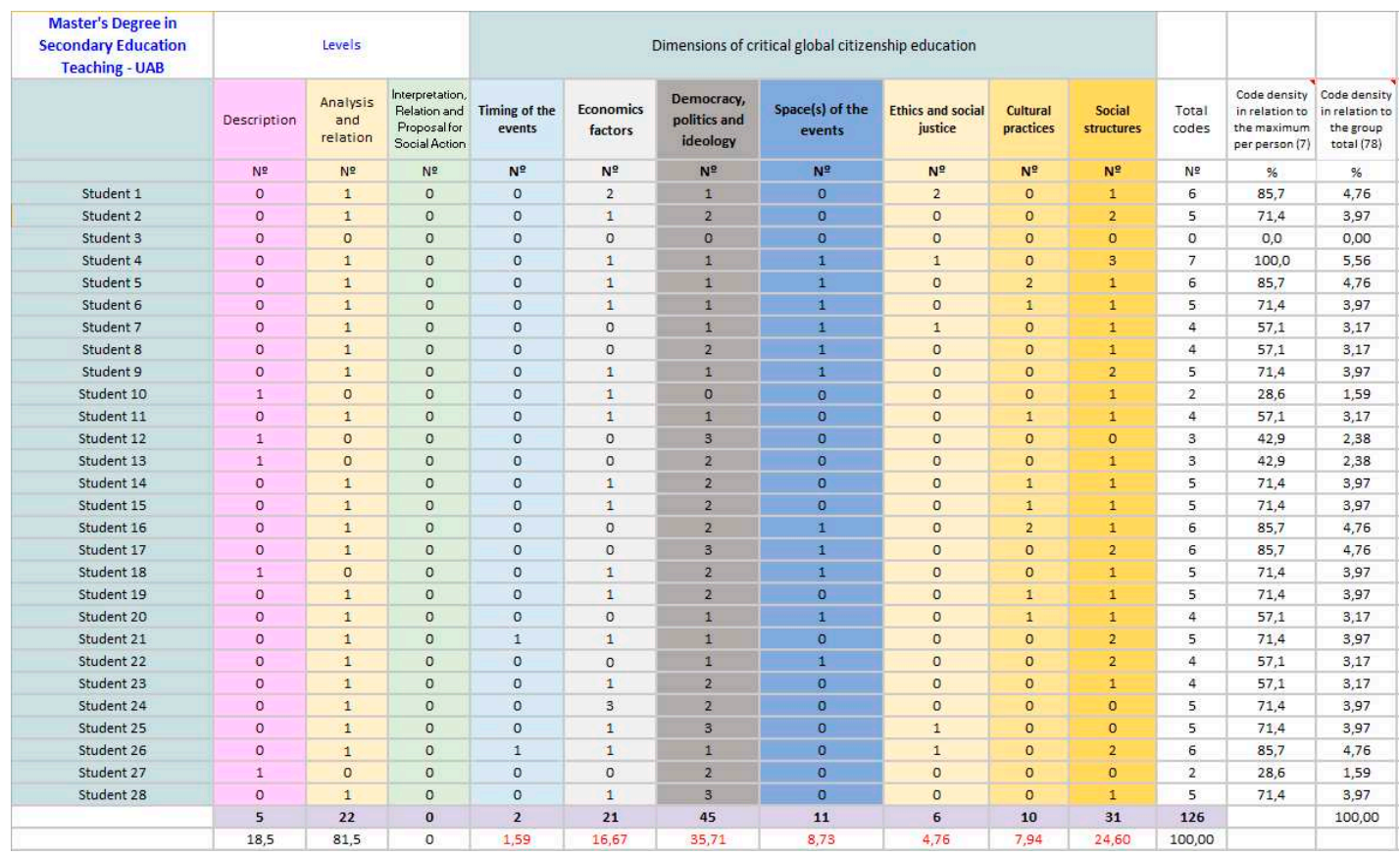

Figure 5. Data emptying matrix-University of Barcelona (UAB).

With the results of this coding, the respondents were classified on a three-level scale which corresponded to what the project assumed to be literacy levels, meant as "the capacity to read between the lines and beyond what is said and to identify the socio-historical and ideological underpinnings and intentionality behind books, images, videos and media" (Castellví et al. 2019, p. 25). Similar scales were used by Bruce et al. (2019) in their study. The scale proposed in this study is:

1. Teachers who focused on the description of the events; that is, those who only referred to the factual aspects of the photograph. These individuals mentioned one or two codes/dimensions: "They are the leaders of the governments of the G20 member countries. The position in which they are established is according to their global importance, so at the beginning, there are leaders like Putin and Trump, and in the end, Mariano Rajoy is smiling. Merkel is located in the centre, because her country that hosts the meeting" (S27UAB). 
2. Teachers who focused on analysis; that is, they identified the factual aspects of the photograph and interpreted what the meeting meant. They mentioned three or four codes/dimensions: "The heads of government of the strongest economies in the world meet often. Why? To strengthen their trade relations and strengthen their power over the rest of the world? This image is a clear expression of inequality in the world, where power and resources are in the hands of the few, and the rest must be satisfied with what little they have, if any. Inequality is also a term for sexes, where of 36 representatives, there are only 4 women." (S11UAB).

3. Critical teachers, that is, those who interpreted the photograph and made suggestions on how to change reality. These individuals mentioned four or more codes/dimensions, with which they analysed the photograph and proposed actions: "In the picture we can see a sample of the patriarchate that is still settled in the institutions and in the spheres of power. It is more difficult for women to arrive, it is a fact, and they have not yet taken the place they deserve, and it is something that must be claimed starting with ourselves from the education itself." (S8UMA).

The correspondence between the number of dimensions and their classification on the scale is due to the fact that using a larger number of codes/dimensions means that people are capable of analysing social facts or cases with a broader, more interdependent and complex perspective and therefore situate themselves within the critical global citizenship education perspective. In order to confirm or refute this assumption, descriptive statistics (frequency and contingency tables) were used, and to determine whether or not there was a significant association among the variables in the study and statistically significant differences between the participating institutions, Spearman correlation coefficients were calculated and the Mann-Whitney-Wilcoxon $U$-test was applied. This shed light on the consistency of the coding (Schreier 2014). The goal of this study was not to measure but to understand how the pre-service teachers reflected the concept of GCE and the dimensions posited in the theorical section in the case analysis. Therefore, this study does not seek to explain experimental cause-effect relations, typical of explanatory studies, but rather the verification of interdependence relations between the variables considered with a comparative objective. Consequently, the study corresponds to the non-experimental designs, of cross-sectional, descriptive, comparative and inferential scope.

This study met the ethical requirements for research with human beings according to the fundamental principles established in the Declaration of Helsinki, and it was approved by the University Senate of the Autonomous University of Barcelona on January 30 of 2013.

\section{Results}

In this section, we present the results of the analysis and the answer research question. We first discuss the descriptive analysis and secondly the inferential analysis; also included are highlighted text passages, obtained from student responses, that characterize each identified trend. Generally speaking, the data are homogeneous.

A total of 53 people responded to the questionnaire; $52.8 \%(n=28)$ were from the Autonomous University of Barcelona $\left(\mathrm{UAB} / \mathrm{U}_{1}\right)$ and $47.2 \%(n=25)$ were from the University of Málaga $\left(\mathrm{UMA} / \mathrm{U}_{2}\right)$. We did not have full access to the gender variable since responding to this item was not obligatory.

The quantitative data analysis was performed based on the frequency of text entries related to the literacy practices observed in the students' texts (description, analysis and association; and interpretation, association and proposal of social action), and with the explanatory dimensions of education for democratic, critical and global citizenship, according to the following codes: $0=$ zero text entries, 1 = one text entry, $2=$ two text entries, $3=$ three text entries. Likewise, the levels of textual density corresponding to the following theoretical dimensions were measured: (1) Between one and three text entries, (2) between four and six text entries, (3) seven or more text entries.

The following quotes reflect the literacy practices and dimensions: Description level "is an international policy meeting, white men predominate, as always"; analysis and association level "is an international policy meeting, the G20, the representatives of the most powerful economies are mostly men, excepting 3 or 4 women. Thus, a system can be affirmed in which the power figures continue 
to be men"; interpretation, association and proposal of social action level: "There are two points of views. The first one shows the lack of female presence. In the other hand that 1 of the 2 women is placed in the centre of the image, probably intentionally. This is a social problem. It cannot be the little female presence in the international political power. We must make ourselves heard, that the female presence grows at the international level, but for that to happen, it must first be born at the national level. Women have the same capacities; we should not have any impediment".

The results for each of the theoretical dimensions of critical global citizenship education (CGCE) reveal at least one text entry per student, with the majority of references related to democracy, politics and ideology $(f .=29,54.7 \%)$ and social structures $(f .=30,56.6 \%)($ Table 1$)$. There is a noticeable absence of references related to the timing of the events and their spatial context $(f .=49,92.5 \% ; f .=37$, $69.8 \%)$, economic factors $(f .=29,54.7 \%)$, ethics and social justice $(f .=42,79.2 \%)$ and cultural practices (f. $=41,77.4 \%)$. The data show no statistically significant differences between the two universities, except on dimensions 5-economic factors $(U=203.000, z=-2,995, p=0.003)$-and 6-democracy, politics and ideology $(U=177.000, z=-3.406, p=0.001)$-with $U_{1}$ having a stronger presence in both areas $(f .=18,64.3 \% ; f .=26,92.9 \%)$.

The students tended to react to the news item proposed at medium levels of textual density, that is, with between four and six text entries referring to one or several of the explanatory theoretical dimensions $(f .=29,54.7 \%)$. $U_{1}$ showed the highest frequencies at this level $(f .=22,78.6 \%)(U=$ $157.000, z=-3.958, p=0.000)$.

The three levels of literacy at which the seven dimensions are addressed reveal the existence of significant differences between the participating institutions in the level of descriptive skills $(U=$ $173.000, z=-3.657, p=0.000)$. Specifically, the students in the first university $\left(\mathrm{U}_{1}\right)(f .=22,78.6 \%)$ are more skilled at receiving and critically understanding the texts and images than those enrolled in the second university $\left(\mathrm{U}_{2}\right)(f .=7,28 \%)$. Despite the fact that, at identical percentages, the use of these skills is complemented with the preferential use of analysis and association skills by $U_{1}(f .=22,78.6 \%)$, the differences between institutions do not yield significant differential values. Likewise, the skill of critically receiving texts and iconographies (interpretation, association and proposal of social action) shows results in $U_{2}(f .=2.8 \%)$, but without significant differences compared to $U_{1}$.

The correlational analysis reveals the existence of low inverse interdependence associations between the application of the students' skills of interpretation, association and proposal for social action and the skills of analysis and association. The more textual references related to these latter skills, the lower the reading practices associated with critical literacy $(\rho=-0.315, p=0.022)$ (Table 2).

The data also reveal that the skills of description, analysis and association bear a minor influence on the construction of text references on economic factors ( $\rho=0.310, p=0.024 ; \rho=0.324, p=0.018)$, just as the skills of analysis and association do in association with the explanatory dimension of social structures $(\rho=0.297, p=0.031)$. Likewise, in references to social structures, there was a low association of significant dependence with the skills of interpretation, association and proposal of social action $(\rho=0.367, p=0.007)$ and of the latter with the ethical and social justice aspects of critical global citizenship $(\rho=0.315, p=0.022)$.

Finally, the references associated with the ethical and social justice aspects revealed the existence of a low inverse association with the references to cultural practices. The more text references on cultural aspects, the fewer ethical references there were $(\rho=-0.274, p=0.047)$. 
Table 1. Descriptive and inferential statistics.

\begin{tabular}{|c|c|c|c|c|c|c|c|c|c|c|c|c|}
\hline & \multirow{2}{*}{ V. } & \multirow{2}{*}{$\mathrm{ft}$} & \multirow{2}{*}{\multicolumn{2}{|c|}{$\begin{array}{c}\mathrm{U}_{1} \\
(n=28)\end{array}$}} & \multirow{2}{*}{\multicolumn{2}{|c|}{$\begin{array}{c}\mathrm{U}_{2} \\
(n=25)\end{array}$}} & \multirow{2}{*}{\multicolumn{2}{|c|}{$\begin{array}{c}\text { Total } \\
(N=53)\end{array}$}} & \multirow{2}{*}{$u$} & \multirow{2}{*}{$W$} & \multirow{2}{*}{$z$} & \multirow{2}{*}{$p$} \\
\hline & & & & & & & & & & & & \\
\hline \multirow{5}{*}{ Literacy levels } & \multirow{2}{*}{$\mathrm{V}_{1}$} & 0 & 6 & $21.4 \%$ & 18 & $12 \%$ & 24 & $45.3 \%$ & \multirow{2}{*}{173.000} & \multirow{2}{*}{498.000} & \multirow{2}{*}{-3.657} & \multirow{2}{*}{$0.000 * *$} \\
\hline & & $\begin{array}{l}1 \\
0\end{array}$ & 22 & $78.6 \%$ & 7 & $28 \%$ & 29 & $54.7 \%$ & & & & \\
\hline & $\mathrm{V}_{2}$ & $\begin{array}{l}0 \\
1\end{array}$ & 6 & $21.4 \%$ & 6 & $36 \%$ & 15 & $28.3 \%$ & 299.000 & 624.000 & -1.164 & 0.244 \\
\hline & \multirow{2}{*}{$\mathrm{V}_{3}$} & 0 & 28 & $100 \%$ & 23 & $92 \%$ & 51 & $96.2 \%$ & \multirow[b]{2}{*}{322.000} & \multirow[b]{2}{*}{728.000} & \multirow[b]{2}{*}{-1.511} & \multirow[b]{2}{*}{0.131} \\
\hline & & 1 & 0 & $0.0 \%$ & 2 & $8.0 \%$ & 2 & $3.8 \%$ & & & & \\
\hline \multirow{22}{*}{$\begin{array}{l}\text { Dimensions of critical global } \\
\text { citizenship education (CGCE) }\end{array}$} & \multirow{3}{*}{$\mathrm{V}_{4}$} & 0 & 26 & $92.9 \%$ & 23 & $92 \%$ & 49 & $92.5 \%$ & & & & \\
\hline & & 1 & 2 & $7.1 \%$ & 2 & $8.0 \%$ & 4 & $7.5 \%$ & 347.000 & 753.000 & -0.117 & 0.907 \\
\hline & & 0 & 10 & $35.7 \%$ & 19 & $76 \%$ & 29 & $54.7 \%$ & & & & \\
\hline & & 1 & 16 & $57.1 \%$ & 6 & $24 \%$ & 22 & $41.5 \%$ & & & & \\
\hline & $v_{5}$ & 2 & 1 & $3.6 \%$ & 0 & $0.0 \%$ & 1 & $1.9 \%$ & 203.000 & 528.000 & -2.995 & $0.003^{* *}$ \\
\hline & & 3 & 1 & $3.6 \%$ & 0 & $0.0 \%$ & 1 & $1.9 \%$ & & & & \\
\hline & & 0 & 2 & $7.1 \%$ & 5 & $20 \%$ & 7 & $13.2 \%$ & & & & \\
\hline & $\mathrm{V}$ & 1 & 11 & $39.3 \%$ & 18 & $72 \%$ & 29 & $54.7 \%$ & & & & \\
\hline & $v_{6}$ & 2 & 11 & $39.3 \%$ & 2 & $8.0 \%$ & 13 & $24.5 \%$ & 177.000 & 502.000 & -3.406 & $0.001+x$ \\
\hline & & 3 & 4 & $14.3 \%$ & 0 & $0.0 \%$ & 4 & $7.5 \%$ & & & & \\
\hline & $\mathrm{V}_{7}$ & 0 & 17 & $60.7 \%$ & 20 & $80 \%$ & 37 & $69.8 \%$ & & & & 0130 \\
\hline & $v_{7}$ & 1 & 11 & $39.3 \%$ & 5 & $20 \%$ & 16 & $30.2 \%$ & 282.500 & 607.500 & -1.512 & 0.130 \\
\hline & & 0 & 23 & $82.1 \%$ & 19 & $76 \%$ & 42 & $79.2 \%$ & & & & \\
\hline & $\mathrm{V}_{8}$ & 1 & 4 & $14.3 \%$ & 5 & $20 \%$ & 9 & $17 \%$ & 329.000 & 735.000 & -0.530 & 0.596 \\
\hline & & 2 & 1 & $3.6 \%$ & 1 & $4.0 \%$ & 2 & $3.8 \%$ & & & & \\
\hline & & 0 & 20 & $71.4 \%$ & 21 & $84 \%$ & 41 & $77.4 \%$ & & & & \\
\hline & $\mathrm{V}_{9}$ & 1 & 6 & $21.4 \%$ & 3 & $12 \%$ & 9 & $17 \%$ & 306.000 & 631.000 & -1.075 & 0.283 \\
\hline & & 2 & 2 & $7.1 \%$ & 1 & $4.0 \%$ & 3 & $5.7 \%$ & & & & \\
\hline & & 0 & 5 & $17.9 \%$ & 3 & $12 \%$ & 8 & $15.1 \%$ & & & & \\
\hline & & 1 & 16 & $57.1 \%$ & 14 & $56 \%$ & 30 & $56.6 \%$ & & & & \\
\hline & $v_{10}$ & 2 & 6 & $21.4 \%$ & 7 & $28 \%$ & 13 & $24.5 \%$ & 315.000 & 721.000 & -0.697 & 0.486 \\
\hline & & 3 & 1 & $3.6 \%$ & 1 & $4.0 \%$ & 2 & $3.8 \%$ & & & & \\
\hline & & $\mathrm{n}_{1}$ & 5 & $17.9 \%$ & 18 & $72 \%$ & 23 & $43.4 \%$ & & & & \\
\hline Textual density & $\mathrm{V}_{11}$ & $\mathrm{n}_{2}$ & 22 & $78.6 \%$ & 7 & $28 \%$ & 29 & $54.7 \%$ & 157.000 & 482.000 & -3.958 & $0.000^{* *}$ \\
\hline & & $\mathrm{n}_{3}$ & 1 & $3.6 \%$ & 0 & $0.0 \%$ & 1 & $1.9 \%$ & & & & \\
\hline
\end{tabular}

$* * p \leq 0.01$. V.: Variable. $\mathrm{V}_{1}$ (description), $\mathrm{V}_{2}$ (analysis and association), $\mathrm{V}_{3}$ (interpretation, association and proposal of social action), $\mathrm{V}_{4}$ (timing of the events), $\mathrm{V}_{5}$ (economic factors), $\mathrm{V}_{6}$ (democracy, politics and ideology), $\mathrm{V}_{7}$ (space(s) of the events), $\mathrm{V}_{8}$ (ethics and social justice), $\mathrm{V}_{9}$ (cultural practices), $\mathrm{V}_{10}$ (social structures) and $\mathrm{V}_{11}$ (textual density). ft: Frequencies of textual entry. $\mathrm{n}_{\mathrm{x}}$ : Levels of textual density (dimensions of GCE). 
Table 2. Spearman correlations among variables.

\begin{tabular}{|c|c|c|c|c|c|c|c|c|c|c|}
\hline & $\mathrm{V}_{1}$ & $\mathrm{~V}_{2}$ & $\mathbf{V}_{3}$ & $\mathrm{~V}_{4}$ & $\mathrm{~V}_{5}$ & $\mathrm{~V}_{6}$ & $\mathrm{~V}_{7}$ & $\mathrm{~V}_{8}$ & $\mathrm{~V}_{9}$ & $\mathrm{~V}_{10}$ \\
\hline $\mathrm{V}_{1}$ & 1 & & & & & & & & & \\
\hline $\mathrm{V}_{2}$ & 0.102 & 1 & & & & & & & & \\
\hline$V_{3}$ & -0.218 & -0.315 * & 1 & & & & & & & \\
\hline $\mathrm{V}_{4}$ & -0.027 & 0.180 & -0.057 & 1 & & & & & & \\
\hline$V_{5}$ & 0.310 * & 0.324 * & -0.178 & 0.152 & 1 & & & & & \\
\hline $\mathrm{V}_{6}$ & 0.157 & 0.219 & -0.072 & 0.005 & 0.199 & 1 & & & & \\
\hline $\mathrm{V}_{7}$ & 0.268 & 0.048 & 0.085 & -0.032 & -0.041 & 0.099 & 1 & & & \\
\hline $\mathrm{V}_{8}$ & -0.093 & 0.122 & $0.367^{* *}$ & 0.023 & 0.136 & -0.065 & -0.044 & 1 & & \\
\hline $\mathrm{V}_{9}$ & 0.214 & 0.244 & -0.106 & -0.154 & 0.101 & 0.023 & 0.151 & -0.274 * & 1 & \\
\hline $\mathrm{V}_{10}$ & -0.054 & $0.297^{*}$ & 0.315 * & 0.164 & -0.095 & -0.139 & 0.207 & 0.207 & -0.114 & 1 \\
\hline
\end{tabular}




\section{Discussion}

The theoretical perspective framing this study was Ortega-Sánchez and Pagès's (2020) critical global citizenship education, which pays particular attention to the role people can play in recognising and acting against global injustices. To do so, it is essential to identify the hegemonic ideological dimensions of news items in order to move towards building global social justice. People can be located at different levels of literacy, which is critical when they interpret news items and propose actions for change. The literacy levels enable us to identify whether people have or are close to having a critical perspective of global citizenship.

Numerous studies have demonstrated the educational relevance of working with controversial topics in the social science classroom (Ortega-Sánchez and Pagès 2020; Ortega-Sánchez and Jiménez-Eguizábal 2019). Likewise, it has been shown that the curricular inclusion of these issues favours the promotion of the concept of active citizenship in educational contexts for democratic citizenship (Pollak et al. 2017), and the development and acquisition of critical-reflective thinking skills (Misco 2013), especially absent in the curriculum and training plans of future teachers in Spain.

Working with controversial issues, such as the one presented in this study, favours the learning of values and democratic participation as educational objectives. Talking about education for citizen participation or for the exercise of active citizenship implies reflecting on the way of teaching in order to intervene, from commitment and responsibility, in relevant social problems or controversial issues. Despite the progress made, there is still a need to design educational programmes and practices specifically aimed at the treatment of social problems and intervention in the community from the perspective of active citizenship (Ortega-Sánchez and Jiménez-Eguizábal 2019).

The data show that there is little association between CGCE and levels of critical literacy. As Kim (2019) and Tarozzi and Mallon (2019) have pointed out, this may be due to the few opportunities for CGCE to be part of teacher training, nor were there any references to postcolonial discourses, which may be due to the excessive presence of the Eurocentric perspective in the training programmes for teachers of history and social sciences. The postcolonial discourse tends to be core in theoretical approaches to CGCE (Andreotti 2006) in reaction to Eurocentric discourses or those centred on economic factors, which tend to be hegemonic.

The analysis shows that pre-service teachers manage to establish associations between the global and local scales, as also found in the studies by Tarozzi and Inguaggiato (2018) and Goren and Yemini (2017b), but this association is limited to statements of several dimensions of GCE which are used to understand news items, while few reach the level of CGCE. These findings match those in Turkey from Çolak et al. (2019); that is, when faced with a news item, there is evidence of an interdependence between the two scales. Both studies also concur on the idea of fostering better understanding of what it means to be a global citizen in the critical perspective geared at seeking greater social justice.

The data show that the future teachers do manage to make connections between the event presented and the global dimension, in this case associated with the negative consequences of the economic decisions taken at gatherings like the one illustrated in the photograph. These findings are coherent with those of Tarozzi and Inguaggiato (2018) and Goren and Yemini (2017b). The consequences cited by the participants were associated with the weakness of democracy, politics and social structures.

The participants managed to associate the consequences of globalisation with the news item analysed (Goren and Yemini 2017a), but they offered few actions to counter the negative consequences of globalisation. In this regard, we concur with Goren and Yemini (2017b) that it is essential to provide tools to go beyond a mere analysis of the events and reach true CGCE.

In terms of literacy, the findings show that most pre-service teachers are located at the analysis level. This matches what Bruce et al. (2019) found in their study, and it takes shape in greater importance being attached to the liberal humanistic dimension. Both studies show that the analysis or understanding of a news item is an essential component of CGCE, but action-transformation proposals truly embody the critical perspective. The two studies differed in their assessment of the effects of globalisation. In the findings of Bruce et al. (2019), globalisation is positively valued in people's 
lives, while in our study, the participants associate it with negative aspects like poverty, inequality, a concentration of wealth, exploitation, etc. (Torres 2009, 2015, 2017).

Regarding the critical level, the analysis showed several differences with the findings of O'Meara et al. (2018). Both studies were framed within a critical perspective and undertook an analysis of a news item associated with the effects of globalisation (migrations, conflicts, etc.). The study by O'Meara et al. (2018) found that respondents reached some level of awareness or critical thinking of the news item analysed. In contrast, this study shows a lower critical level. This comparison is pertinent because both studies were approached from the critical perspective and with similar events associated with the process of globalisation.

Related to the dimensions, the people located at the critical level share the fact that their responses referred to aspects associated with democracy, politics and ideology, ethics and justice and social structures. Based on these dimensions, the actions that emerged were geared towards changing unjust situations associated with discrimination against women and lowering poverty levels. These findings directly reflect the CGCE and critical literacy approaches of Ortega-Sánchez and Pagès (2017), who suggest that pre-service teachers who will teach the social sciences have to try to make social justice a teaching goal. They particularly noted that "the invisibility of people and social groups ... prevents them from being identified as those involved in the news items and further limits the constructive pluralisation of their own personal and social identities" (Ortega-Sánchez and Pagès 2017, p. 115).

The textual dimension suggests that pre-service teachers analyse the news items from different dimensions, the most common ones being democracy, politics and ideology, and social structures. The absence of references to the timing or spatial context of the events was striking because the teachers participating in these trainings often came from degree programmes in history and geography. It was interesting that references to ethics and social justice were the essential difference between those located on a critical level and those who were not. These findings match those of O'Meara et al. (2018), who found similar references in their study. These dimensions appear explicitly in the approaches of Andreotti (2006), Davies (2006) and Oxley and Morris (2013) when they state that CGCE should explicitly include the quest for social justice.

The data show that overall there are few references to the economic dimension. This is interesting since economics is at the core of the event in the news item. These results differ from what Bruce et al. (2019) found, which is that the participants referred to economic factors in their way of understanding GCE, and even if these factors were not at the core, they did occupy an important position.

The three levels of literacy proposed show that the people who responded to the questionnaires were essentially at the analysis level, followed by the descriptive level and finally the critical level. No combination of two levels was found in the data, unlike the findings of Bruce et al. (2019), who did identify combinations of the critical and descriptive levels. In this study, the critical level had a low incidence in the results. This leads us to posit that it is difficult to achieve critical global citizenship education if teachers do not reach equivalent levels of understanding. In order to overcome a more descriptive or positivistic perspective, Bruce et al. (2019, p. 14) suggest that it is "crucial to disrupt the hegemonic structures and belief systems which have brought us to this global crisis. Technicist and humanistic approaches serve largely to shore up and reinforce the status quo".

\section{Conclusions}

Based on the findings of this study, we can conclude that pre-service teachers are far from materialising a CGCE geared at social justice (Sant 2018). There is still a need to develop and implement proposals that allow pre-service teachers to address and understand the implications of globalisation. In this vein, we concur with Howe (2013) and O'Meara et al. (2018, p. 16), who suggest that "only when GCE capacity-building becomes part of a teacher education core-curriculum, will these global concerns sustainably be addressed, implemented, and assessed". One way of developing a better understanding of CGCE may be using strategies that favour associations between globalisation and 
news items by analysing cases, or even service learning (Kopish 2016) or global education programmes, such as the EU's Erasmus Programme (Larsen and Searle 2017), which explicitly address aspects of global citizenship.

With regard to the question that guided the research—when analysing a news item with global implications, do teachers in training which critical literacy achieve and use the dimensions of the critical global citizenship education model and which critical literacy achieve?-the teachers performing the analysis of the case used three or four dimensions, usually politics, democracy and social structure, while they left out at least half of the dimensions. The people located at the critical level included the majority of dimensions in their analysis. Another difference found was that the people on this level considered the ethics and social justice dimension. These findings pose a new question: What should be done in pre-service teacher training to achieve a level of CGCE in a case analysis? Below we shall outline several proposals.

Teacher training programmes must include spaces that allow for debate on news items with a global perspective (Kim 2019; Tarozzi and Mallon 2019; Sant 2018) in order for CGCE to have a greater presence in teacher training. By doing so, teachers will better understand the global dimensions of news items (O'Meara et al. 2018).

CGCE can only reach classrooms provided that pre-service teachers understand and work with news items that reflect the effects of globalisation (Yang et al. 2017) and include the critical perspective of global citizenship. The data show that the participants are working in this direction, but teacher training programmes still need to make a greater effort to bring in historical, geographic, political and economic factors, and even factors associated with social structures and ethical considerations and the quest for social justice (González 2013; González and Santisteban 2016). Only in this way will they produce critical teachers geared at social transformation and overcoming the negative consequences of globalisation processes.

The proposal of the CGCE dimensions and literacy levels to analyse information can be viewed as a means of working towards overcoming the Eurocentric perspective that characterises the way history, geography and the social sciences, as well as teacher training, are taught. The theoretical proposal was pertinent because it shed light on how pre-service teachers analyse news items via the dimensions and levels proposed. The key point in overcoming this perspective entails addressing the consequences of globalisation in other parts of the world. In other words, the goal is to overcome 20th century colonialism and 21st century neo-colonialism and to build a world that calls for a globalisation more permeated with social justice. To achieve this, a critical look at global citizenship education is needed (Andreotti 2006; Oxley and Morris 2013).

The data show that ethics and social justice are two dimensions present at the critical level, so they should have a core place in the design of training proposals targeted at analysing an event that reflects GCE. One way to bring this to fruition would be by using socially timely questions or relevant social problems, as proposed by Santisteban and Santisteban and González-Monfort (2018), Ortega-Sánchez and Olmos (2018), Davies (2006) and Davies et al. (2005), because they question the established order and the way the social sciences, history, geography and global citizenship are taught.

A limitation of this study is the political moment (global and local), because the particular social factors may have an influence on the answers to the questions, although the sample is future teachers. Citizenship, democracy and political education are influenced by many aspects; it is necessary to carry out research on these. The methodological approach was quantitative, which is usual in political studies, but in the future it will be necessary to do qualitative analyses.

Author Contributions: Conceptualization, G.G.-V., M.B. and D.O.-S.; methodology, G.G.-V., M.B. and D.O.-S.; software, D.O.-S.; validation, D.O.-S.; formal analysis, D.O.-S.; investigation, G.G.-V., M.B. and D.O.-S.; resources, G.G., M.B. and D.O.-S.; data curation, G.G., M.B. and D.O.-S.; writing—original draft preparation, G.G.-V., M.B. and D.O.-S.; writing-review and editing, G.G.-V., M.B. and D.O.-S.; visualization, G.G.-V., M.B. and D.O.-S.; supervision, G.G.-V., M.B. and D.O.-S.; project administration, G.G.-V., M.B. and D.O.-S.; funding acquisition, G.G.-V., M.B. and D.O.-S. All authors have read and agreed to the published version of the manuscript. 
Funding: This publication is part of the R \& D Project Teach and learn to interpret contemporary problems and conflicts. What do the Social Sciences contribute to the formation of a critical global citizenship?, financed by the Ministry of Economy and Competitiveness (Spain) (EDU2016-80145-P), whose main researcher is Professor Antoni Santisteban (Universitat Autònoma de Barcelona).

Conflicts of Interest: The authors declare no conflict of interest.

\section{References}

Andreotti, Vanessa. 2006. Soft versus critical global citizenship education. Policy E Practice-A Development 3: $40-51$.

Anguera, Carles, Neus González-Monfort, Ana María Hernández, Sandra Muzzi, Delfín Ortega-Sánchez, Joan Pagès, and Antoni Santiesteban. 2018. Invisibles y ciudadanía global en la formación inicial. In Buscando Formas de Enseñar: Investigar Para Innovar en Didáctica de las Ciencias Sociales. Edited by Esther López, Carmen García and María Sánchez. Valladolid: Universidadad de Valladolid-Asociación Universitaria de Profesorado de Didáctica de las Ciencias Sociales, pp. 403-12.

Argibay, Juan C. 2009. Muestra en investigación cuantitativa. Subjetividad y Procesos Cognitivos 13: 13-29.

Arthur, James, Ian Davies, and Caroles Hahn, eds. 2008. Sage Handbook of Education for Citizenship and Democracy. London: Sage.

Barber, Benjamin R. 1984. Strong Democracy: Participatory Politics for a New Age. Berkeley: University of California Press.

Bardin, Lawrence. 2002. El Análisis de Contenido. Madrid: Akal.

Broomley, Patricia. 2009. Cosmopolitanism in civic education: Exploring cross-national trends, 1970-2008. Current Issues in Comparative Education 12: 33-44.

Bruce, Judy, Chris North, and Jessica FitzPatrick. 2019. Preservice teachers' views of global citizenship and implications for global citizenship education. Globalisation, Societies and Education 17: 161-76. [CrossRef]

Castells, Manuel. 2005. La era de la Información Economía, Sociedad y Cultura. Madrid: Alianza.

Castellví, Jordi, Mariona Massip, and Joan Pagès. 2019. Emociones y pensamiento crítico en la era digital: un estudio con alumnado de formación inicial. Revista de Investigación en Didáctica de las Ciencias Sociales 5: $23-41$.

Çolak, Kerem, Yücel Kabapınar, and Cemil Öztürk. 2019. Social Studies Courses Teachers' Views on Global Citizenship and Global Citizenship Education. Ted Ĕ̆itim Ve Bilim 44: 335-52. [CrossRef]

Cortina, Adela. 2003. Ciudadanos del mundo: Hacia una Teoría de la Ciudadanía. Madrid: Alianza.

Davies, Lynn. 2006. Global citizenship: abstraction or framework for action? Educational Review 58: 5-25. [CrossRef]

Davies, Ian, Mark Evans, and Alan Reid. 2005. Globalising citizenship education? A critique of 'global education' and 'citizenship education.'. British Journal of Educational Studies 53: 66-89. [CrossRef]

Dei, George. 2008. Anti-racism education for global citizenship. In Global Citizenship Education: Philosophy, Theory and Pedagogy. Edited by Michael A. Peters, Alan Britton and Harry Blee. Rotterdam: Sense Publishers, pp. 477-90.

Delanty, Gerard. 1997. Models of Citizenship: Defining European Identity and Citizenship. Citizenship Studies 1: 37-41. [CrossRef]

Dill, Jeffrey. 2013. The Longings and Limits of Global Citizenship Education: the Moral Pedagogy of Schooling in a Cosmopolitan Age. London: Routledge.

Faulks, Keith. 2000. Citizenship. London: Routledge.

Flick, Uwe. 2012. Introducción a la Investigación Cualitativa. Madrid: Morata.

Freire, Paulo. 1970. Pedagogy of the Oppressed. New York: Continuum.

González, Gustavo. 2013. La formación inicial del profesorado y la educación para la ciudadanía: representaciones sociales, diseño de clases y prácticas de enseñanza. Enseñanza de las Ciencias Sociales 12: 37-45.

González, Gustavo, and Antoni Santisteban. 2016. La formación ciudadana en la educación obligatoria en Colombia: entre la tradición y la transformación. Revista Educación E Educadores 19: 89-102.

Goren, Heela, and Miri Yemini. 2016. Global citizenship education in context: Teacher perceptions at an international school and a local Israeli school. Compare: A Journal of Comparative and International Education 46: 832-53. [CrossRef] 
Goren, Heela, and Miri Yemini. 2017a. The global citizenship education gap: Teacher perceptions of the relationship between global citizenship education and students' socio-economic status. Teaching and Teacher Education 67: 9-22. [CrossRef]

Goren, Heela, and Miri Yemini. 2017b. Global citizenship education redefined-A systematic review of empirical studies on global citizenship education. International Journal of Educational Research 82: 170-83. [CrossRef]

Goren, Heela, Claire Maxwell, and Miri Yemini. 2019. Israeli teachers make sense of global citizenship education in a divided society-religion, marginalisation and economic globalisation. Comparative Education 55: 243-63. [CrossRef]

Government of Spain. 2015. Real Decreto 1105/2014, de 26 de Diciembre, por el que se Establece el Currículo Básico de la Educación Secundaria Obligatoria y del Bachillerato; Madrid: Boletín Oficial del Estado.

Gun Chung, Bong, and Inyoung Park. 2016. A Review of the Differences between ESD and GCED in SDGs: Focusing on the Concepts of Global Citizenship Education. CICE Hiroshima University, Journal of International Cooperation in Education 18: 17-35.

Hernández, Roberto, Carlos Fernández, and Pilar Baptista. 2010. Metodología de la investigación. Mexico: McGraw-Hill.

Howe, Edward R. 2013. Alternatives to a master's degree as the new gold standard in teaching: A narrative inquiry of global citizenship teacher education in Japan and Canada. Journal of Education for Teaching 39: 60-73. [CrossRef]

Isin, Engin, and Bryan Turner, eds. 2002. Handbook of Citizenship Studies. New York: Sage.

Janoski, Thomas, and Brian Gran. 2002. Political citizenship: Foundations of rights. In Handbook of Citizenship Studies. Edited by Engin Isin and Bryan Turner. New York: Sage, pp. 13-52.

Kim, Yeji. 2019. Global citizenship education in South Korea: ideologies, inequalities, and teacher voices. Globalisation, Societies and Education 17: 177-93. [CrossRef]

Kopish, Michael. 2016. Preparing globally competent teacher candidates through cross-cultural experiential learning. Journal of Social Studies Education Research 7: 75-108.

Krippendorff, Klaus. 1990. Metodología de Análisis de Contenido. Barcelona: Paidós.

Kymlicka, Will, and Wayne Norman. 1994. Return of the citizen: A survey of recent work on citizenship theory. Ethics 104: 352-81. [CrossRef]

Larsen, Marianne, and Michelle Searle. 2017. International service learning and critical global citizenship: A cross-case study of a Canadian teacher education alternative practicum. Teaching and Teacher Education 63: 196-205. [CrossRef]

Leduc, Rhonda. 2013. Global Citizenship Instruction Through Active Participation: What Is Being Learned About Global Citizenship? The Educational Forum 77: 394-406. [CrossRef]

Miles, Mattthew, A. Michael Huberman, and Johnny Saldaña. 2014. Qualitative Data Analysis: A Methods Sourcebook. London: Sage.

Misco, Thomas. 2013. 'We do not talk about these things': The promises and challenges of reflective thinking and controversial issue discussions in a Chinese high school. Intercultural Education 24: 401-16. [CrossRef]

O'Meara, James, Tonya Huber, and Elizabeth Sanmiguel. 2018. The role of teacher educators in developing and disseminating global citizenship education strategies in and beyond US learning environments. Journal of Education for Teaching 44: 556-73. [CrossRef]

Ortega-Sánchez, Delfín. 2017. Las mujeres en la enseñanza de la Historia y de las Ciencias Sociales: estudio de caso en formación inicial de maestros y maestras de Educación Primaria. Ph.D. dissertation, Universitat Autònoma de Barcelona, Bellaterra, Spain. Available online: https://ddd.uab.cat/record/187752 (accessed on 25 March 2020).

Ortega-Sánchez, Delfín, and Alfredo Jiménez-Eguizábal. 2019. Project-Based Learning through Information and Communications Technology and the Curricular Inclusion of Social Problems Relevant to the Initial Training of Infant School Teachers. Sustainability 11: 6370. [CrossRef]

Ortega-Sánchez, Delfín, and Rafael Olmos. 2018. Los problemas sociales relevantes o las cuestiones socialmente vivas en la enseñanza de las ciencias sociales. In Contribuciones de Joan Pagès al desarrollo de la didáctica de las ciencias sociales, la historia y la geografía en Iberoamérica. Edited by Miguel Ángel Jara and Antoni Santisteban. Cipolletti: Universidad de Comahue-UniversitatAutònoma de Barcelona, pp. 203-14. 
Ortega-Sánchez, Delfín, and Joan Pagès. 2017. Literacidad crítica, invisibilidad social y género en la formación 651 del profesorado de Educación Primaria. REIDICS: Revista de Investigación en Didáctica de Las Ciencias Sociales 1: 102-17.

Ortega-Sánchez, Delfín, and Joan Joan Pagès. 2020. The End-Purpose of Teaching History and the Curricular Inclusion of Social Problems from the Perspective of Primary Education Trainee Teachers. Social Sciences 9: 9. [CrossRef]

Oxley, Laura, and Paul Morris. 2013. Global Citizenship: A Typology for Distinguishing its Multiple Conceptions. British Journal of Educational Studies 61: 301-25. [CrossRef]

Pagès, Joan, and Antoni Santisteban. 2014. Una mirada del pasado al futuro en la didáctica de las ciencias sociales. In Una Mirada al Pasado y un Proyecto de Futuro. Investigación e Innovación en Didáctica de las Ciencias Sociales. Edited by Joan Pagès and Antoni Santisteban. Barcelona: Servicio de Publicaciones de la Universitat Autònoma de Barcelona-Asociación Universitaria de Profesorado de Didáctica de las Ciencias Sociales, pp. 17-39.

Pak, Soon. 2013. Global Citizenship Education. Goals and Challenges in the New Millennium. Seoul: UNESCO-APCEIU. Pak, Soon-Yong, and Moosung Lee. 2013. 'Hit the ground running': Delineating the problems and potentials in State-led Global Citizenship Education (GCE) through teacher practices in South Korea. British Journal of Educational Studies 66: 515-35. [CrossRef]

Pollak, Italy, Aliza Segal, Adam Lefstein, and Assaf Meshulam. 2017. Teaching controversial issues in a fragile democracy: defusing deliberation in Israeli primary classrooms. Journal of Curriculum Studies 50: 387-409. [CrossRef]

Rapoport, Anatoli. 2009. A Forgotten Concept: Global Citizenship Education and State Social Studies Standards. The Journal of Social Studies Research 33: 91-112.

Rauner, Mary. 1999. UNESCO as an organizational carrier of civic education information. Journal of Educational Development 19: 91-100. [CrossRef]

Reysen, Stephen, and Iva Katzarska-Miller. 2013. A model of global citizenship: Antecedents and outcomes. International Journal of Psychology 48: 858-70. [CrossRef] [PubMed]

Sant, Edda. 2018. We, the non-global citizens: Reflections on the possibilities and challenges of democratic global citizenship education in higher education contexts. Citizenship Teaching $\mathcal{E}$ Learning 13: 273-92.

Sant, Edda, and Gustavo González-Valencia. 2018. Global Citizenship Education in Latin America. In The Palgrave Handbook of Global Citizenship and Education. Edited by Ian Davies, Li-Ching Ho, Dina Kiwan, Carla L. Peck, Andrew Peterson, Edda Sant and Yusef Waghid. London: Palgrave Macmillan, pp. 67-82.

Santisteban, Antoni. 2015. La formación del profesorado para hacer visible lo invisible. In Una enseñanza de las Ciencias Sociales para el futuro: Recursos para trabajar la invisibilidad de personas, lugares y temáticas. Edited by Ana María Hernández, Carmen R. García and Juan L. de la Montaña. Cáceres: University of Extremadura-Asociación Universitaria de Profesorado de Ciencias Sociales, pp. 383-93.

Santisteban, Antoni. 2019. La enseñanza de las Ciencias Sociales a partir de problemas sociales o temas controvertidos: estado de la cuestión y resultados de una investigación. El Futuro del Pasado 10: 57-79. [CrossRef]

Santisteban, Antoni, and Neus González-Monfort. 2018. La mirada holística en la enseñanza de las ciencias sociales. In Contribuciones de Joan Pagès al desarrollo de la didáctica de las ciencias sociales, la historia y la geografía en Iberoamérica. Edited by Miguel Ángel Jara and Antoni Santisteban. Cipolletti: Universidad de Comahue-UniversitatAutònoma de Barcelona, pp. 103-112.

Santisteban, Antoni, and Gustavo González-Valencia. 2013. Sociedad de la información, democracia y formación del profesorado ¿qué lugar debe ocupar el pensamiento crítico? In Medios de Comunicación y Pensamiento Crítico: Nuevas Formas de Interacción Social. Edited by Juan J. Díaz, Antoni Santisteban and Aurea Cascajero. Alcalá de Henares: Servicio de Publicaciones de la Universidad de Alcalá de Henares-Asociación Universitaria de Profesorado de Didáctica de las Ciencias Sociales, pp. 689, 761-70.

Scheunpflug, Annette, and Barbara Asbrand. 2006. Global education and education for sustainability. Environmental Education Research 12: 33-46. [CrossRef]

Schreier, Margrit. 2014. Qualitative Content Analysis. In The SAGE Handbook of Qualitative Data Analysis. Edited by Uwe Flick. London: Sage, pp. 170-83.

Scribano, O. 2007. El proceso de Investigación Social Cualitativo. Buenos Aires: Prometeo Libros. 
Shultz, Lynette. 2007. Educating for global citizenship: Conflicting agendas and understandings. Alberta Journal of Educational Research 53: 248-58.

Sklair, Leslie. 1999. Competing conceptions of globalization. Journal of World-Systems Research 2: 143-63. [CrossRef] Spring, Joel. 2004. How Educational Ideologies are Shaping Global Society. Mahwah: LEA.

Stromquist, Nelly. 2009. Theorizing Global Citizenship: Discourses, Challenges, and Implications for Education FlacsoAndes. Interamerican Journal of Education for Democracy 2: 6-29.

Stromquist, Nelly, and Karen Monkman. 2014. Globalization and Education: Integration and Contestation Across Cultures. Plymouth: Rowman \& Littlefield Education.

Szelényi, Katalin, and Robert Rhoads. 2007. Citizenship in a Global Context: The Perspectives of International Graduate Students in the United States. Comparative Education Review 51: 25-47. [CrossRef]

Tarozzi, Massimilliano, and Carla Inguaggiato. 2018. Teachers' Education in GCE: Emerging Issues in a Comparative Perspective-UCL Discovery. Trento: Provincia Autonoma di Trento.

Tarozzi, Massimiliano, and Benajmin Mallon. 2019. Educating teachers towards global citizenship: A comparative study in four European countries. London Review of Education 17: 112-25. [CrossRef]

Tawil, Sobhi. 2013. Education for "global citizenship": A framework for discussion. UNESCO Education Research and Foresight 7: 1-8.

Torres, Carlos. 2009. Globalizations and Education: Collected Essays on Class, Race, Gender, and the State. New York: Teachers College Press.

Torres, Carlos. 2015. Global Citizenship and Global Universities. The Age of Global Interdependence and Cosmopolitanism 50: 262-79.

Torres, Carlos. 2017. Theoretical and Empirical Foundations of Critical Global Citizenship Education. New York: Taylor and Francis.

Tosar, Breogán, and Antoni Santisteban. 2016. Literacidad crítica para una ciudadanía global: una investigación Educación Primaria. In Deconstruir la Alteridad Desde la Didáctica de las Ciencias Sociales. Educar para una Ciudadanía Global. Edited by Carmen García, Dolores Arroyo and Beatriz Andreu. Las Palmas: Universidad de Las Palmas de Gran Canaria-Asociación Universitaria de Profesorado de Didáctica de las Ciencias Sociales, pp. 674-83.

Tully, James. 2014. On Global Citizenship: James Tully in Dialogue. New York: Bloomsbury.

UNESCO. 2015. Global Citizenship Education: Topics and Learning Objectives. Paris: UNESCO.

UNESCO. 2018. Preparing Teachers for Global Citizenship Education: A Template-UNESCO Digital Library. Bangkok: UNESCO.

Yang, MiSeok, Jeong Kyounm Kim, and KiDuck Kim. 2017. A Study on Variables Related to Global Citizenship Teaching Efficacy of Secondary School Pre-service Teachers and In-service Teachers. Association of Global Studies Education 9: 77-104. [CrossRef]

Yemini, Miri. 2017. Internationalization and Global Citizenship: Policy and Practice in Education. Tel Aviv: Palgrave Macmillan.

Yemini, Miri, Felisa Tibbitts, and Heela Goren. 2019. Trends and caveats: Review of literature on global citizenship education in teacher training. Teaching and Teacher Education 77: 77-89. [CrossRef]

(C) 2020 by the authors. Licensee MDPI, Basel, Switzerland. This article is an open access article distributed under the terms and conditions of the Creative Commons Attribution (CC BY) license (http://creativecommons.org/licenses/by/4.0/). 



\title{
Students' Social Representations of Forced Migration as a Relevant Social Problem and Its Curricular Inclusion at the End of Primary School
}

\author{
Roberto García-Morís ${ }^{1, * \mathbb{D}}$, Nerea García Bugallo ${ }^{1}$ and Ramón Martínez-Medina ${ }^{2, * \mathbb{D}}$ \\ 1 Department of Specific Teaching Training and Research and Diagnosis Methods in Education, \\ Faculty of Educational Studies, University of Coruña, 15008 A Coruña, Spain; nerea.garciab@udc.es \\ 2 Department of Specific Teaching Training, Faculty of Educational Studies, University of Córdoba, \\ 14071 Córdoba, Spain \\ * Correspondence: roberto.garcia.moris@udc.es (R.G.-M.); rmartinez@uco.es (R.M.-M.)
}

\section{check for} updates

Citation: García-Morís, Roberto, Nerea García Bugallo, and Ramón Martínez-Medina. 2021. Students' Social Representations of Forced Migration as a Relevant Social

Problem and Its Curricular Inclusion at the End of Primary School. Social Sciences 10: 423. https://doi.org/ 10.3390/socsci10110423

Academic Editor:

Delfín Ortega-Sánchez

Received: 20 September 2021

Accepted: 1 November 2021

Published: 4 November 2021

Publisher's Note: MDPI stays neutral with regard to jurisdictional claims in published maps and institutional affiliations.

Copyright: (c) 2021 by the authors. Licensee MDPI, Basel, Switzerland. This article is an open access article distributed under the terms and conditions of the Creative Commons Attribution (CC BY) license (https:/ / creativecommons.org/licenses/by/ $4.0 /)$.

\begin{abstract}
The purpose of this paper is to assess students' social representations of forced migration as a relevant social problem in the last year of primary education and the opportunity for its curricular inclusion. The study was carried out by means of a questionnaire, filled in by 6th-year primary education groups (11-12 years old) $(n=70)$, in a state-supported private school in the city of A Coruña (Galicia, Spain). The questionnaire was supported by three pictures of forced migrations from the media. In this case, the children had to interpret the pictures through a series of questions that sought to investigate their representations, the causes they identify in this social problem, their opinions, and possible solutions. Finally, the opportunity for the inclusion of social problems as curriculum content was addressed. The study shows that the students are in favor of migrants, that they use concepts from the social sciences in their arguments-albeit simple ones, and that they are in favor of the curricular inclusion of social problems, in which they develop representations through different sources of information.
\end{abstract}

Keywords: citizenship education; social studies; controversial social questions; primary school students

\section{Introduction}

This paper incorporates in its title the term "social representations", a fairly common concept in the Didactic of Social Science research. This notion comes from the field of Social Psychology thanks to the pioneering work of Moscovici (1976) and Jodelet (1989) and it takes into consideration the existing relationship between people and their environment.

Araya (2002) notes that "when people refer to social objects, classify them, explain them and, moreover, evaluate them, it is due to the fact that they have a social representation of that object" (p. 11). According to the same author, these representations are formed, first, by the cultural background accumulated by people and society over time, and then by the anchoring mechanisms, i.e., the incorporation of knowledge into representations and the influence of social structures, to which the role of the media and interpersonal relationships must be added (Araya 2002).

Following Pagès and Oller (2007, p. 6), we could define them as "a set of information, opinions, and values that constitute a more or less well-structured 'pre-knowledge' that provides explanations, more or less elaborated, about a situation, a present or past event, a problem, a conflict, a subject, etc."

Therefore, once we are aware of what this concept refers to, we should ask ourselves what the purpose of our attempt to understand these representations is, and more specifically those of pupils in the last year of primary school. The main reason lies in their importance in shaping the teaching-learning process, as it is necessary to detect them to 
consolidate or modify them, since exploring these representations "is essential for teaching, as learning is considered to be about modifying these representations" (Pagès and Oller 2007, p. 6).

There are recent studies in our area of knowledge on the social representations of a wide range of subjects-especially controversial social issues-most of them carried out by the Autonomous University of Barcelona. In particular, we can highlight the work of Pagès and Oller (2007), who studied the representations of law, justice, and legislation in Catalan students in the 4th year of ESO, concluding that they were shaped outside of the educational system and that they are quite similar to those of adolescents in other European countries. Marolla and Pagès Blanch (2015) approached the representations of women's history among Chilean secondary school teachers. Sant et al. (2011) examined Catalan teenagers' representations of democratic participation. Moreover, social representations of immigration were the subject of study in Bergamaschi's (2011) work, examined alongside attitudes in a comparative survey carried out in France and Italy.

On the process of transformation of social representations, the thesis by Salinas (2017) — which focuses on participation in social problems of the community - is noteworthy. Other studies by Salinas et al. (2016) focus on social representations of citizen participation among Chilean Social Science teachers and primary school students (Salinas and Oller 2017). Moreover, representations of the economic crisis (Olmos et al. 2017; Olmos and Pagès 2017) or contemporary problems in teacher training (Ortega and Pagès 2017) are good examples of the study of social representations around an issue, a problem or some relevant concepts conducted within the field of Social Sciences Didactics.

This study is part of a larger research that addresses the curricular inclusion of social problems among students at different levels of schooling in northwest Spain, more specifically in Galicia. The purpose of the main study is to understand the social representations of forced migration as a social problem among students in the last year of primary education and its curricular inclusion. Following the same line of research, we have also investigated students' representations at the end of secondary education (García-Morís and Oller 2022), which allows us to compare the results between the studies conducted in both stages.

\section{Theoretical Framework}

\subsection{The Purpose of Social Sciences and the Curricular Inclusion of Social Problems}

The social approach of Geography and History in Spain gained ground in the last decades of the 20th century within the emerging field of Social Sciences Didactics (Benejam 1992, 1997; Fien 1992; Pagès 1994). This approach, which could be called a critical approach, corresponds to one of the dominant paradigms in research on the teaching and learning of the Social Sciences, but not in educational practice at the primary and secondary level. In the Spanish case, it was first defined from the epistemology of the Didactics of Geography (Benejam 1992, 1997), and later of the Didactics of History (Pagès 1994, based on Evans 1991).

In Spain - in line with what has been defended in other European countries and also in North America (Simonneaux and Legardez 2010) - there is an increasing number of specialists in Social Sciences Didactics who defend the need to orientate the teaching and learning of Social Sciences, Geography, and History towards relevant social problems (Oller 1999, 2011; Santisteban 2009; Pagès and Santisteban 2011b; García-Pérez 2014; Pagès 2016, among others), although this notion is still rare in the classroom.

"A Social Sciences for global citizenship must consider, analyze, and value the possibilities of approaches centered on relevant social problems (RSP), on socially acute questions (SAQ), on everyday life, on controversial issues or on the disciplinary knowledge generated to analyze, interpret, and try to solve all sorts of problems" (Pagès 2016, p. 725).

The VII International Seminar on Teaching Social Studies Research organized by the Autonomous University of Barcelona in 2010 was devoted exclusively to relevant social problems. For this reason, both for an approach to their meaning and a review of this subject in the Spanish and international scene, the work resulting from the conference 
is an essential reference (Pagès and Santisteban 2011b). In the Anglo-Saxon tradition, the label "relevant social problems" or "controversial issues" is used (Evans and Saxe 1996; Hurst and Ross 2000), while in the more recent French tradition, the term "socially acute questions" is used (Audigier 2001; Tutiaux-Guillon 2011; Legardez 2003; Legardez and Simonneaux 2006; Thénard-Duvivier Franck 2008), both having in common their orientation towards democratic citizenship.

The contribution of the Canadian author Legardez (2003) delimits, from a conceptual point of view, what is encompassed by the concept of "social and historical, socially acute questions", which are those that are alive in society, in the reference knowledge and educational knowledge. Le Roux (2002) analyzes the approach to Geography and History problems, fine-tuning what we understand by problems.

Although in Spain one might say that curricular research based on relevant social problems is fairly recent, it follows a line that connects with the research initiated at the Autonomous University of Barcelona by Benejam and Pagès on the teaching of contemporary issues (Benejam 1997). The research carried out at the UAB was closely related to this approach, as it focused on democratic political education, education for citizenship, problems related to everyday life, the development of historical awareness, and the shaping of temporality with a special emphasis on the future (Pagès and Santisteban 2011a). The connection between social problems and social and civic competence is key in this approach.

In the Spanish case, due to the legislative changes that took place in education during the democratic period, it is impossible not to link this approach to the debate on Education for Citizenship or on the key competences, especially social and civic competences, as was the case in the European context. This competence should be connected with the critical approach to Social Sciences, since-although competences are dealt with in all areas of the curriculum-social and civic competence was claimed as part of the area of Social Sciences Didactics. Santisteban (2009) understands that this competence must be worked on through the approach and resolution of social problems since most of the issues that people face in their daily lives "have to do with personal relationships, social values or the experiences of men and women. In addition, these problems are often of an economic, political, sociological or anthropological nature" (p. 12).

In this sense, the role of teachers is essential in the development of this competence, as they "propose or help in defining the problem-situations, create the conditions to solve them and provide information, show possible ways of reasoning, encourage reflection and debate, lead towards an attitude open to discovery, and help in reviewing the ideas" (Santisteban 2009, p. 12). All of this is linked to learning about the future, to consider the future as part of our subject in this permanent dialogue with the past and the present.

Classroom work on social and civic competence must ensure that children and teenagers in our schools understand and act, that they are able to solve problems, that they imagine the future and, above all, that their projects do not end up in oblivion or inaction (Santisteban 2009, p. 15).

However, the vindication of the work on social and civic competence, and the development of social thinking have not only remained at the theoretical level. Moreover, there is research on the implementation of educational proposals along these lines. Santisteban et al. (2014); Santisteban (2019) presented a study on the introduction of controversial issues to address citizenship competence and the development of social thinking, in which they explored social representations, developed curricular materials, and analyzed their implementation.

Ross and Vinson (2012) introduce the concept of "dangerous citizenship", which is important to highlight at this point as it refers to a critical, social justice-oriented citizenship that resists the dominant power, i.e., that opts for the implementation of participation, to which it gives a fundamental role.

Both research and proposals for curriculum organization based on socially acute questions have grown considerably in the Didactics of Social Science in Spain. However, 
its transference to the educational system is slow and its presence is rare. Therefore, it is necessary to act in teacher training to change this scenario. According to Pagès (2007), the approach focused "on relevant social problems is a great opportunity for citizenship education since, as Dewey proposed, it brings young people closer to the world and prepares them for life" (p. 208).

\subsection{Migration as a Relevant Social Problem}

The social question chosen for this work is frequently shown in the media, especially with the arrival of African migrants across the Mediterranean, which is the source of two of the images used in this research. However, it should be pointed out that it is not migration itself that is the subject in this research, but rather forced migration and the conditions in which people are forced to move.

In 1950, the UN created the United Nations High Commissioner for Refugees (UNHCR), and in 1951 "refugee" was defined as a person who "owing to a well-founded fear of being persecuted for reasons of race, religion, nationality, membership of a particular social group or political opinion, is outside the country of his [or her] nationality". The problem with this definition of refugee lies mainly in its limitations, as people displaced by war or natural disasters, for example, are not considered to be refugees, something that does not seem to be changing for the time being for the United Nations.

Those who cannot prove that they face persecution in their home country are not considered refugees and are seen as "economic migrants", a distinction soon made by the receiving countries as to whether to accept asylum. Migrants are considered a burden on the state in the main so-called "rich" receiving areas-mainly the United States, Europe, and Australia-thus, the existence today of numerous border controls, as well as major people-smuggling mafias.

The work of Kabunda (2017) presents an interesting synthesis of migration in Africa. Among the factors that generate migratory movements are wealth inequality, the existence of transnational networks, and the degree of poverty in the countries of origin and rejection by the receiving ones. Apart from the causes, the positive aspects of migratory phenomena for both Africa and Europe were also presented, which are mainly two-fold: The arrival of remittances in the countries of origin and the rejuvenation of the population in the countries of destination.

These remittances are estimated to represent 3\% of Africa's GDP. In addition to financing families' necessity goods and prestige, these remittances contribute to improving aspects of social justice and human development in the countries of origin and therefore contribute to reduce poverty. According to the World Bank, the 20 million African immigrants transferred nearly 31 billion dollars to Africa in 2014. Moreover, the intangible benefits generated by social and cultural remittances should be underlined (Kabunda 2017 , p. 46). Furthermore, some of the advantages of the migration's impact in Spain are included in the Report Immigration in Spain: Effects and Opportunities (Economic and Social Council of Spain 2019).

The positive effects of migration in economic terms are not the exclusive patrimony of the countries of origin, but there are also benefits for the receiving areas. For the European Union, "migration is an economic necessity not only due to the growing ageing of the population, but also due to the need, as in the previous case, for cheap migrant labor" (Kabunda 2017, p. 46). Beyond all of the economic stimulus that migration can bring, the human rights violations that are taking place not only in the countries of origin, but also in the countries of destination, as well as in the so-called transit zones, must be taken into account (Table 1). 
Table 1. Violation of migrants' human rights.

\begin{tabular}{|c|c|c|}
\hline $\begin{array}{c}\text { In the Countries of } \\
\text { Origin }\end{array}$ & In the Transit Zones & In the Countries of Destination \\
\hline $\begin{array}{l}\text { Weakness of the } \\
\text { institutional protection } \\
\text { system }\end{array}$ & $\begin{array}{c}\text { Exploitation, extortion, abuse, } \\
\text { assault, and police raids, as } \\
\text { well as the dangers of sea and } \\
\text { land routes }\end{array}$ & $\begin{array}{c}\text { Hiding, exclusion, threat of } \\
\text { expulsion, and imposition of } \\
\text { duties without recognizing their } \\
\text { rights }\end{array}$ \\
\hline \multirow[t]{2}{*}{$\begin{array}{l}\text { Violation of human rights } \\
\text { due to the lack of } \\
\text { economic democracy and } \\
\text { popular participation }\end{array}$} & $\begin{array}{l}\text { Exploitation by human } \\
\text { trafficking networks }\end{array}$ & $\begin{array}{l}\text { Racism, xenophobia, } \\
\text { ultra-right-wing discourse, and } \\
\text { attitudes that pathologize } \\
\text { immigration }\end{array}$ \\
\hline & & $\begin{array}{l}\text { Restrictive social integration } \\
\text { policies and reduction of work } \\
\text { permits }\end{array}$ \\
\hline
\end{tabular}

Based on Kabunda (2017).

The solution to this relevant social problem lies "not in the closure of borders, but in the efficient management of circular migration in order to achieve brain gain (the costeffectiveness of human capital circulation)" (Kabunda 2017, p. 49). Undoubtedly, the promotion of measures in the countries of origin-such as the recovery and fulfilment of the social and economic functions of the state in African countries, demographic transition, training, and generation of infrastructures and technologies, etc.- could be part of the solution.

Although brief, the above data are sufficiently representative of the fact that the displacement of people throughout the world generates strong conflicts and great inequalities, which are a constant violation of human rights, representing today one of the major social problems on a global scale.

\subsection{Research on the Migration Problems in the Social Sciences Didactics}

For the last section of our theoretical framework, we have conducted a literature review in order to identify other research that has recently dealt with migration from an educational research perspective, mainly in the Spanish context. We have not focused on research on immigrants in the education system — of which there are numerous works, such as those of Fernández-Batanero (2004), Ortiz (2008) or the report on educational challenges in the face of immigration (Aja et al. 1999), among others-but we are specifically interested in an area with a smaller production: Representations and how to approach migrations from the perspective of teaching and learning in Social Sciences.

One of the studies that most closely resembles what we intend to accomplish in this paper is the recent work by Gil et al. (2018) on the representations of immigration in children in the last year of primary school. The research, carried out through a questionnaire and a focus group, deals with the family history of the students to find out the ideas surrounding the statement "we are all immigrants". The research concludes that the students' social representations "differentiate the immigrant and the foreigner, the former as someone who moves out of necessity, especially for economic reasons, conflicts or insecurity, the latter as someone who goes to another country, without further descriptions" (p. 32). In addition, the authors were satisfied with the favorable attitudes of the participating primary school children towards migrants.

In a study carried out by Llonch et al. (2014) for the same educational stage, but in two different contexts, the authors proposed the encouragement of motivation through the migratory roots of the students and an interesting didactic proposal. Initially, the participating students were familiar with the term immigration, but they had a negative view of it. Then, with the implementation of the proposal, this view changed. However, this work is more about the analysis of the didactic proposal carried out and the didactic materials generated rather than the change in social representations. Moreover, noteworthy is the 
work by Tosar et al. (2016) on critical literacy based on the interpretation of information of the recent refugee crisis.

Serulnicoff and Bernardini (2015) presented a reflection on the teaching of migration processes to children, questioning some of the methodologies through which this topic was introduced in Argentinean schools and proposing a series of resources for its inclusion in the classroom, ranging from testimonies to itineraries, including fragments of letters, all of them quite conventional.

Haro et al. (2016) incorporated immigration into a teaching proposal for the 3rd year of ESO based on controversial issues. The authors called the didactic unit: What about immigration? In addition, they posed a series of questions about the motivating force of migrants, their sociology, and the role of institutions, formulating three interesting questions for debate: What happens to the migrants who arrive? What does the receiving population think? What does it mean to live in a multicultural society? (p. 401). The authors conclude that "knowledge and understanding of other people and cultures require students to constantly question their own social reality, to acknowledge social problems and their causes", and that this "helps them in recognizing the complexity of respecting different points of view in order to become aware of the need to build multicultural and multi-identity societies" (p. 405).

Although more examples could be included, we will discuss three research studies that focus on initial teacher training. Jiménez et al. (2002) presented an experience of working on immigration in the classroom. Of particular interest is the work of Rodríguez-Izquierdo (2009) on the social image of immigrants held by trainee teachers. Although the author focuses on attitudes through semantic differential rather than on social representations, she reaches important conclusions. She notes minority attitudes of explicit rejection, although tolerance predominates. According to Rodríguez-Izquierdo (2009) "the reactions of the students can be classified as a receptive attitude, of unreserved acceptance or what we call optimistic multiculturalism" (p. 272).

The issue of refugees and migrants from the perspective of Citizenship and Civic Education was explored in a recent monograph (Acikalin et al. 2021), in which the work of Blanck (2021) stands out, addressing teachers' prior ideas about migration and their decisions to guide educational practice on this issue.

Moreover, there is research on the treatment of migration in textbooks, such as the work of Taboada $(2016,2018)$ or Balsas $(2013,2014)$ for the Argentinean case. Finally, it is worth highlighting the thesis by Haro (2017) on social justice, which incorporates the analysis by secondary school students of an image on the rescue of immigrants (p. 203).

Increasing knowledge about migrants, a heterogeneous reality, fostering a change in attitudes, and the involvement in the resolution of social problems, are the main purpose of the educational treatment of this subject. This is a major social problem of global scope, and throughout this theoretical framework, this issue has been discussed in relation to the main theoretical references on social problems relevant to the Didactics of Social Sciences.

\section{Materials and Methods}

\subsection{Questions, Premises, and Objectives}

As mentioned above, the main objective of this research is to learn about the students representations of migrants in the last year of primary school (6th grade, 11-12 years old), with special attention to the Mediterranean case. These representations have been developed mainly through information from the social environment, including the media (Araya 2002). The research questions to be answered in this paper are the following:

1. What are the social representations of forced migration that 6th-year primary school students have?

2. What are the opinions they have about this social problem?

3. What are the solutions that they propose to repair this relevant social problem?

4. Where does the information they have about this issue come from and what do they think about the school's approach to it? 
Based on the existing literature and the research we have previously carried out, we begin with several premises. The first, based on the study by Gil et al. (2018) on primary school students' conceptions of immigration, is that these students have social representations, which they associate with the idea of physically moving people to another place and which come from different sources of information. As a second premise-and following the same study - students at the end of primary school identify the causes of this phenomenon, mainly through economic motivation. In addition, and as a third premise, students have opinions about this phenomenon. Moreover, looking at the study by Gil et al. (2018), and at the one by García-Morís and Oller (2022), we observe that students recognize some sensitive issues such as racism, relating it to aspects such as skin color or religion. There are no prejudices or negative attitudes towards immigrants, and students are also favorable towards their curricular treatment. These research questions, and the initial premises, are intended to be verified through the following objectives:

1. To analyze the social representations of forced migration among students at the end of the primary school stage.

2. To analyze the opinions that students in the last year of primary school have about the situations that migrants go through.

3. To identify the solutions that the children propose for this social problem.

4. To analyze the contexts in which the students learnt what they know about this social problem and their opinion about the inclusion of this content in the curriculum.

\subsection{Participants}

The study was carried out with the 6th-year primary school groups (11-12 years old) of a state-supported private school in the city of A Coruña (Galicia, Spain), a Catholic school that receives public funding. The socio-economic level of families is average, and the majority of pupils are Spanish-born (89\%), although there are some children born in or with at least one parent from other countries, mainly Latin America (11\%).

The sample was based on accessibility and convenience, as the individuals were easily approachable by the authors. The school follows a traditional methodology, although it is characterized by carrying out numerous solidarity projects to help people in at-risk situations.

Eighty-nine percent of the children's families are of Spanish origin and $11 \%$ are from foreign families or with one of the parents of a non-Spanish origin. Within the latter case, the Venezuelan nationality stands out (38\% of foreign families). Moreover, it was found that $21 \%$ of the students had a family member (mother or father) who had been an emigrant outside of Spain at some point in their lives.

\subsection{Research Instrument}

A questionnaire was designed for the research, based on the model of Pagès and Oller (2007) for the study of Catalan teenagers' representations of law and justice, which was used for this study and for García-Morís and Oller's (2022) work on social representations of migration among secondary school students.

The questionnaire was divided into two parts, with a series of open-ended questions with images for the students to answer freely. The first part, entitled "What do these images tell me?", comprises questions 1 to 4 , and includes the students' interpretations of the selected images, inquiring about the representations, causes, opinions, and possible solutions to this social problem. Each of the images reflects a migration situation present in society, thus it was expected that they would be familiar or close to them. The images were not accompanied by any kind of prior information.

Three media images were included in the questionnaire. The first two belong to scenes of migration in the Mediterranean (Figures 1 and 2) and the third to refugees in Mexico (Figure 3). The images were chosen from a wider selection since they depicted different moments experienced by migrants in forced displacement. One image was about 
displacement by sea and the risks involved, the second about transit, and the last reflected the walls and deprivation of freedom of passage and movement of migrants.

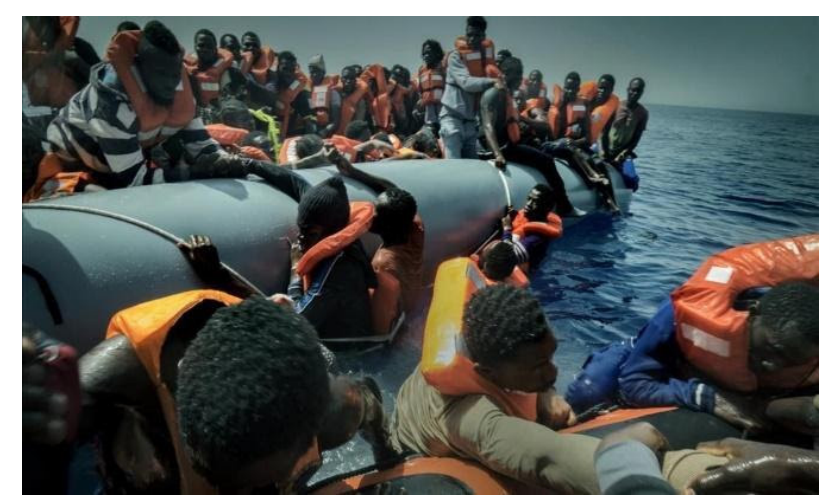

Figure 1. (Rescue) from the questionnaire. Source: Boats in the Mediterranean. Photograph by Ricardo García Vilanova. Libyan waters 2016. El Periódico.

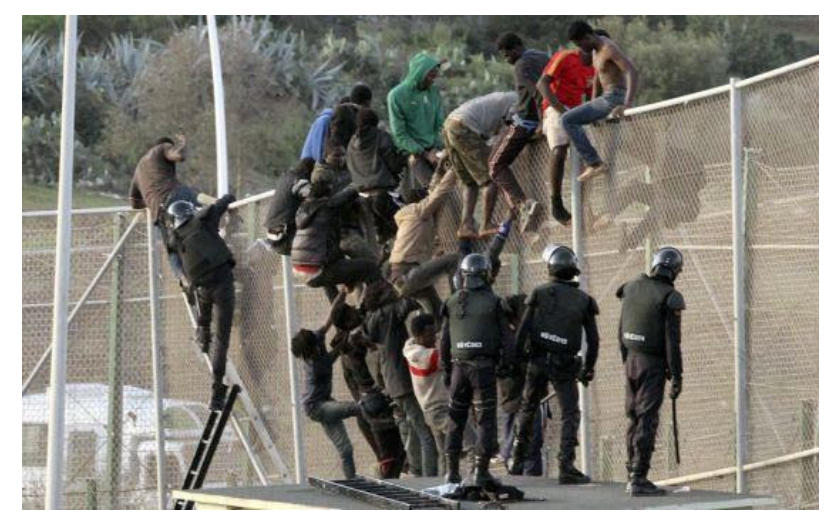

Figure 2. (Fence) from the questionnaire. Source: Photograph by Antonio Ruiz. Melilla, October 2014. El País.

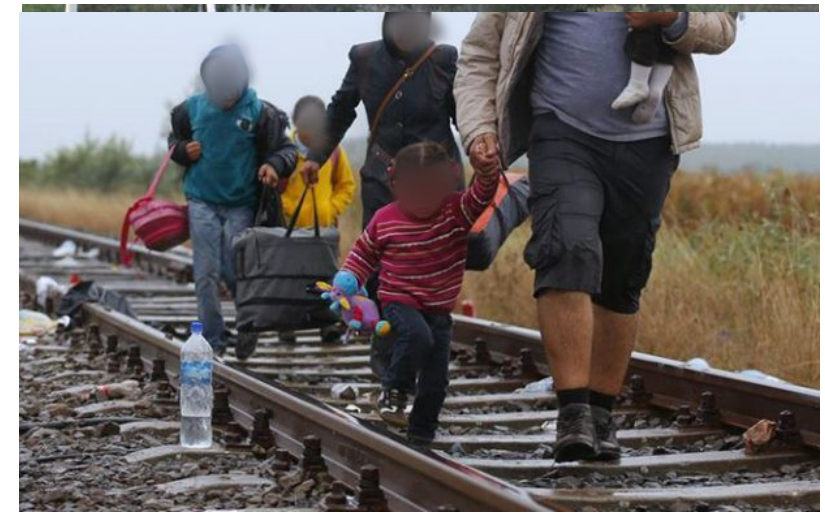

Figure 3. (Refugees) from the questionnaire. Source: https://www.elnuevodiario.com.ni/ internacionales/420740-mexico-pais-transito-pais-acogida-refugiados / (accessed on 20 September 2021).

\subsection{Method of Data Collection and Analysis}

The questionnaire was printed on paper and distributed to all of the 6th-year primary school groups during a Social Studies lesson. The data were processed using the commercial software Microsoft Excel, which allowed the responses to be categorized and quantified.

The procedure followed for data analysis was different for each question. The images were presented to the students without any explanation of their origin or the situation 
portrayed in them. Question 1 made it possible to analyze the representations, grouping similar concepts that described or analyzed the reality represented. The same procedure was followed for questions 2,3, and 4, which focused on the causes, opinions, and possible solutions to this problem. Question 5 was closed, thus the answers were quantified, and question 6, related to the teaching and learning process of these subjects, was processed by grouping those with identical answers.

\section{Results}

\subsection{Social Representations of Migration}

4.1.1. The Interpretation of Images

In the first point of the questionnaire, students were asked to answer questions from the photographs such as What people do you see? What is happening? Why is it happening?

The interpretation of Figure 1 (Rescue) was contextualized. As can be seen in Table 2, students associate the forced displacement of people with causes intrinsic to the countries of origin, such as fleeing war (15.69\%), poverty (15.33\%) or seeking a better life $(12.04 \%)$. Within this contextualized analysis, demographic concepts such as immigrants $(10.58 \%)$ or emigrants $(9.12 \%)$ are incorporated. There is another group of answers that identify the elements of the image, but in a less contextualized way, referring to the protagonists of the scene as "people in boats" $(8.76 \%)$, people fleeing $(7.66 \%)$ or simply boys, girls, men, and women $(5.84 \%)$ or even lifeguards $(4.01 \%)$ and black men $(2.55 \%)$. To a lesser extent, political and economic problems or the impossibility of legal migration are mentioned.

Table 2. Social representations from Figure 1 (Rescue).

\begin{tabular}{ccc}
\hline Answer & Frequency & \% \\
\hline Fleeing war & 43 & 15.69 \\
Fleeing poverty & 42 & 15.33 \\
Seeking a better life & 33 & 12.04 \\
Immigrants & 29 & 10.58 \\
Emigrating & 25 & 9.12 \\
People in boats & 24 & 8.76 \\
People fleeing & 21 & 7.66 \\
Boys/girls, W/M & 16 & 5.84 \\
Lifeguards & 11 & 4.01 \\
In danger & 8 & 2.92 \\
Poor & 8 & 2.92 \\
Black men & 7 & 2.55 \\
Political, economic problems & 5 & 1.82 \\
Impossibility of legal migration & 2 & 0.73 \\
\hline
\end{tabular}

Moreover, the interpretation of Figure 3 (Refugees) was analyzed in a contextualized way (Table 3), since in the narratives constructed by the children to respond to the queries in the questionnaire-although they refer to "people fleeing" (21.94\%) - they incorporated concepts such as "fleeing poverty" (15.83\%), "migrating" (11.87\%), "fleeing war" (8.99\%) or "seeking a better life" (8.63\%), i.e., responses that reflect an interpretative analysis of the image, mainly associated with intrinsic causes in the countries of origin. To a lesser extent, other more descriptive concepts are used, such as "walking on the tracks" (8.27\%) or looking for a place to sleep $(0.72 \%)$. Furthermore, they associated the images with being in danger $(5.76 \%)$, immigrating $(2.52 \%)$, having no money or work $(3.96 \%)$ or being poor $(2.88 \%)$. One of the pupils identifies the image as a Syrian family. 
Table 3. Social representations from Figure 3 (Refugees).

\begin{tabular}{ccc}
\hline Answer & Frequency & $\%$ \\
\hline People fleeing & 61 & 21.94 \\
Fleeing poverty & 44 & 15.83 \\
Immigrating & 33 & 11.87 \\
Fleeing war & 25 & 8.99 \\
Seeking a better life & 24 & 8.63 \\
Boys/girls, W/M & 23 & 8.27 \\
Walking on the tracks & 23 & 8.27 \\
In danger & 16 & 5.76 \\
No money/work & 11 & 3.96 \\
Poor & 8 & 2.88 \\
Immigrants & 7 & 2.52 \\
Looking for a place to sleep & 2 & 0.72 \\
Syrian family & 1 & 0.36 \\
\hline
\end{tabular}

The interpretation of Figure 2 (Fence) received some clearly descriptive responses such as "boys jumping a fence" (13.8\%), young boys $(10.14 \%)$ or even, in one case, a group of friends (Table 4). In the descriptions, students identified the presence of the police $(10.81 \%)$ as "the police blocking their way" (8.78\%) or "chasing them" (5.74\%). In other words, $25.68 \%$ of the responses referred to the police being present at the scene, making them the most identified elements in the narratives. Only one case analyzes the police presence positively, considering that "the police helps them". In a more interpretative way, another group of answers identified people fleeing $(12.16 \%)$ or linked the scene again to causes such as poverty $(7.43 \%)$, the search for a better life $(6.76 \%)$ or war $(5.74 \%)$. For some of the students, they are immigrants (4.39\%), border-crossers $(4.73 \%)$, and $5.41 \%$ are identified as "people who are escaping from prison", i.e., in a negative view.

Table 4. Social representations from Figure 2 (Fence).

\begin{tabular}{ccc}
\hline Answer & Frequency & $\%$ \\
\hline Boys jumping a fence & 39 & 13.18 \\
People fleeing & 36 & 12.16 \\
Police & 32 & 10.81 \\
Young boys & 30 & 10.14 \\
Police blocking their way & 26 & 8.78 \\
Fleeing poverty & 22 & 7.43 \\
Seeking a better life & 20 & 6.76 \\
Fleeing war & 17 & 5.74 \\
Police chasing them & 17 & 5.74 \\
Escaping from prison & 16 & 5.41 \\
Crossing the border & 14 & 4.73 \\
Immigrants & 13 & 4.39 \\
Fleeing danger & 6 & 2.03 \\
Poor & 5 & 1.69 \\
Looking for help & 1 & 0.34 \\
Police helping & 1 & 0.34 \\
Group of friends & 1 & 0.34 \\
\hline
\end{tabular}

To further explore the causes, a second question was included with the following wording: Why do you think the people in the images are travelling or moving from place to place? (Table 5). The results confirm the responses analyzed above, as they place the causes in the war in the countries of origin $(29.23 \%)$, poverty $(29.23 \%)$, seeking a better life $(20 \%)$ or fleeing from dangerous situations (10\%). The political and economic situation $(7.69 \%)$ or homelessness are among the causes least mentioned by students (3.85\%). 
Table 5. Identified causes.

\begin{tabular}{ccc}
\hline Answer & Frequency & \% \\
\hline Fleeing war & 38 & 29.23 \\
Fleeing poverty & 38 & 29.23 \\
Seeking a better life & 26 & 20.00 \\
Fleeing danger & 13 & 10.00 \\
Political, economic situations & 10 & 7.69 \\
Homelessness & 5 & 3.85 \\
\hline
\end{tabular}

\subsubsection{Students' Views on the Events Observed in the Images}

In addition, the questionnaire asked for the students' opinions of what was happening in the images. As can be seen in Table 6, the most repeated answers reject the existence of these situations, with $23.81 \%$ of the answers stating that "this situation should not happen". This is followed by "it is worrying" (20.95\%) or "it is unfair" (14.29\%). In other words, there is a clear rejection of forced migration. In general, students are aware that these people have a hard time $(6.67 \%)$ and that solutions need to be found $(13.33 \%)$, which is why they advocate equal rights and opportunities $(4.76 \%)$ as one of the possible solutions. Only one case of a pupil considered that it was not their problem.

Table 6. Students' opinions.

\begin{tabular}{ccc}
\hline Answer & Frequency & \% \\
\hline Should not happen & 25 & 23.81 \\
It is worrying & 22 & 20.95 \\
It is unfair & 15 & 14.29 \\
It needs to be fixed & 14 & 13.33 \\
No to war and poverty & 7 & 6.67 \\
They are having a hard time & 7 & 6.67 \\
Equality & 5 & 4.76 \\
Must look for new opportunities & 4 & 3.81 \\
I disagree with the situation & 3 & 2.86 \\
They are risking their lives & 2 & 1.90 \\
Nothing, it is not my problem & 1 & 0.95 \\
\hline
\end{tabular}

\subsubsection{Possible Solutions to Forced Migration Proposed by Students}

Finally, the proposed solutions provided by the students are analyzed (Table 7). The majority of the children support the option of helping, and within this, the following forms of help are included: Giving money, food, work, and housing, solutions which account for over $53 \%$ of the total responses. Moreover, ending war (13.64\%) or seeking equal rights and opportunities $(10.91 \%)$ are recurrent solutions.

Table 7. Proposed solutions by students.

\begin{tabular}{ccc}
\hline Answer & Frequency & $\%$ \\
\hline Help: Money, food, work, housing & 59 & 53.64 \\
No to war & 15 & 13.64 \\
Equality & 12 & 10.91 \\
Solidarity & 7 & 6.36 \\
Support the NGOs & 6 & 5.45 \\
Let them move to other countries & 5 & 4.55 \\
Choosing the right president & 3 & 2.73 \\
No to racism & 2 & 1.82 \\
Nothing, it is not my problem & 1 & 0.91 \\
\hline
\end{tabular}

Furthermore, $6.36 \%$ consider that the solution lies in solidarity and in the support and empowerment of NGOs (5.45\%). Another solution, following the students' terminology, 
would be to "let them move to other countries" (4.55\%) or to eliminate racism (1.82\%). Although not very representative, the solution proposing a correct election of the president is striking $(2.73 \%)$. Once again, we find a response that considers that it is "not my problem", but, as can be seen, the majority of answers place the solutions in the destination countries, externally, not in the countries of origin and their people.

\subsection{The Educational Approach to Forced Migration as a Relevant Social Problem}

\subsubsection{Where Have They Learned What They Know about this Social Problem?}

All of the students answered affirmatively when asked if they had ever heard of or read about this social problem. In addition, when asked where this information came from, they put the media in the first place, mainly the news $(34.43 \%)$ (Table 8$)$. The family is in second place $(20.77 \%)$ and, significantly behind, the school (12.57\%). To a lesser extent, the newspaper $(12.02 \%)$, the Internet $(10.93 \%)$, others $(7.10 \%)$, and through friends $(2.19 \%)$.

Table 8. Where students learned that they know about the issue.

\begin{tabular}{ccc}
\hline Answer & Frequency & \% \\
\hline News & 63 & 34.43 \\
Home & 38 & 20.77 \\
School & 23 & 12.57 \\
Newspaper & 22 & 12.02 \\
Internet & 20 & 10.93 \\
Others & 13 & 7.10 \\
Friends & 4 & 2.19 \\
\hline
\end{tabular}

\subsubsection{Why Address This Issue in the Classroom?}

First, we asked the students whether they thought it was necessary to address this issue in the classroom. Eighty-seven percent of the answers were affirmative, compared to the $12 \%$ that were negative. Those students who considered it important to address this issue said that it was necessary to know about it to "be informed" (39.78\%) (Table 9). Moreover, they considered it important to "help" (19.35\%) and to "raise awareness" (18.28\%). Furthermore, it was considered important to address these issues to "prevent them from happening" $(8.60 \%)$ and to try to achieve equal rights and opportunities $(3.23 \%)$. Finally, $8.60 \%$ simply felt that it was important to be aware of the issue.

Table 9. Why address this issue in the classroom.

\begin{tabular}{ccc}
\hline Title $\mathbf{1}$ & Title $\mathbf{2}$ & Title 3 \\
\hline Be informed & 37 & 39.78 \\
Help & 18 & 19.35 \\
Raise awareness & 17 & 18.28 \\
Prevent it from happening & 8 & 8.60 \\
It is important & 7 & 7.53 \\
Equality & 3 & 3.23 \\
NR/DK & 2 & 2.15 \\
It is not important & 1 & 1.08 \\
\hline
\end{tabular}

\section{Discussion}

The first of the premises made was that students have social representations about migration, a concept they associate with the idea of the physical movement of people from one place to another, identifying part of its causes. The research verified this premise, confirming that, in their narratives, 6th-year primary school children use some concepts from the Social Sciences to explain what they see in the images of forced migration. In order to interpret them, they use some of the causes of the phenomenon in their arguments, as was presented in the second premise. Given that we have carried out a previous study (García-Morís and Oller 2022), with the same instrument but with pupils at the 
end of the secondary stage, in this section we make some comparisons between the social representation made by students at both educational stages.

Among the main causes identified are economic, conflict, and insecurity, which are consistent with the study by Gil et al. (2018) and also with the research we have conducted with secondary school students in a study similar to the present one (García-Morís and Oller 2022). In other words, the conception of the migrant as someone who "moves out of necessity, especially for economic reasons, conflicts or insecurity" (Gil et al. 2018, p. 32) occurs both at the end of primary school (12 years old) and secondary school (16 years old). In the case of secondary school students, most of the causes are found in the countries of origin. However, they also identified some external causes, showing a lack of analysis with a historical perspective, of interdependence between countries, characteristic of a global world. Logically, in the case of primary school students, given their age, the causes are simplified, and all of them were contextualized in the countries of origin, excusing developed countries from any kind of responsibility.

As a third premise, we maintained that students had opinions about this phenomenon, which we have verified in this study. The opinions of students at the end of secondary school on migration phenomena are often stereotypical, although they were favorable towards migrants and focused mainly on describing the events. In the case of 6th-year children, most of the opinions also focus on describing the situation, rejecting that it happens.

The possible solutions provided by students to this social phenomenon can be grouped into those that are in the hands of the countries of origin, and those that are given to countries of destination, mainly developed countries. In the case of secondary education, there is a Europeanist vision with little perspective of otherness, which-although it does not reach the geographical, cultural, and even ethnic determinism identified in similar research at the end of the last century (Gil 1993)_only gives importance to the developed countries in the solutions. In the case of primary education, this was even more intense, as the solutions provided were dominated by the resolution of this social problem in the form of economic aid. In other words, solving the problem from outside and without giving the countries of origin and their citizens the capacity to overcome their current situation.

As mentioned above, primary school students, as well as secondary school students, shape their representations through different sources of information. In both cases, they point to television as the main source from which they have learned something about this issue, most likely since the arrival of immigrants, especially from Africa to Spain, is a constant in the media, and children also consume news in the family environment. Another coincidence between students at both states is that, after the news, the family is the second most important source of information. In the case of primary education, the school is the third place, and in secondary education, the Internet is the third most popular source of information.

Regarding the need for the curricular inclusion of these topics, both secondary and primary school students consider it important to address them in the class. Although in the case of secondary school the first reason for their inclusion is to raise awareness, while primary school students opt for being informed as the first option. We agree with Blanck (2021) that, although 12-year-olds may be too young to understand phenomena in a structural way, it is "important not to underestimate what pupils already know and have the opportunity to understand" (p. 97). Therefore, addressing social problems in the classroom is essential to place Social Sciences in the orbit of citizenship education and to work on social and civil competence (Santisteban 2009), and to develop critical social sciences for social change (Gil et al. 2018). Gil et al. (2018) considered that working on migration is very necessary "to differentiate the causes for which people are forced to leave their homes and become migrants, displaced persons, exiles or refugees" (p. 33). There is no doubt that a theoretical deepening of these issues is needed, something that should also be done at the primary stage.

Furthermore, migrations can be approached by relating them to family and local experiences, which is an interesting didactic opportunity and helps in empathizing with 
other cultures and working on diversity (Balsas 2013; Blanck 2021; Gil 1993; Gil et al. 2018; Hammond 2010). Therefore, it is necessary to take advantage of their educational opportunities (Ernst-Slavit Gisella 2018), which also contributes to combat possible xenophobic discourses (McCorkle 2018).

\section{Conclusions}

The curricular inclusion of social problems, either by organizing the curriculum through socially acute questions or through the problematization of historical and geographical contents of a more classical nature, clearly dominates research in Didactics of Social Sciences in Spain. However, and despite the regulatory changes that are taking this perspective into account, the real transference of this model to primary and secondary classrooms is slow. For this to become a reality, it is necessary to act in the initial training of teachers, in order for the curricular deficiencies to be complemented in the development of the curriculum in the classroom. As has been observed, primary school children are favorable to including these social issues in the curriculum. Therefore, it is necessary to continue exploring the representations in order to formulate well-oriented didactic proposals that contribute to the development of critical citizenship, the main purpose of Social Sciences.

However, although we are dealing with a case study, focused on a specific school, which we have also carried out with secondary school students (García-Morís and Oller 2022) and whose conclusions are not generalizable, it is common to observe in the results of this type of studies that pupils are in favor of the inclusion of these current social issues as a central theme in Social Sciences subjects. This curricular approach contributes to the development of an education for citizenship and human rights, which is why its development represents a great educational opportunity.

Author Contributions: Conceptualization, R.G.-M. and N.G.B.; methodology, R.G.-M. and N.G.B.; formal analysis, R.G.-M. and N.G.B.; investigation, R.G.-M., N.G.B. and R.M.-M.; resources, R.G.-M., N.G.B. and R.M.-M.; data curation, R.G.-M., N.G.B. and R.M.-M.; writing-original draft preparation, R.G.-M. and R.M.-M.; writing-review and editing, R.G.-M. and R.M.-M. All authors have read and agreed to the published version of the manuscript.

Funding: This research is part of the project Children's, adolescents', and youth rights: Inhabiting activist projects with students, teachers, and contemporary artists of the State Programme for Knowledge Generation and Scientific and Technological Strengthening of the R\&D\&i System and R\&D\&i Oriented to the Challenges of Society, of the State Plan for Scientific and Technical Research and Innovation 2017-2020; funded by the Ministry of Science and Innovation of the Government of Spain, with code: PID2020-117147RA-I00, and Principal Investigator: José María Mesías Lema.

Institutional Review Board Statement: Not applicable.

Informed Consent Statement: Not applicable.

Data Availability Statement: Not applicable.

Conflicts of Interest: The authors declare no conflict of interest.

\section{References}

Acikalin, Mehmet, Olga Bombardelli, and Gina Chianese. 2021. Editorial: Citizenship and Civic Education for Refugees and Migrants. Journal of Social Science Education 20: 1-4. [CrossRef]

Aja, Eliseo, Francesc Carbonell, Colectivo Ioé, Jaume Funes, and Ignasi Vila. 1999. La Inmigración Extranjera en España. Los Retos Educativos. Barcelona: Fundación La Caixa.

Araya, Sandra. 2002. Las Representaciones Sociales: Ejes Teóricos Para su Discusión. San José: Flacso-Facultad Latinoamericana de Ciencias Sociales.

Audigier, François. 2001. Les contenus d'enseignement plus que jamais en question. In Entre Culture, Compétence et Contenu: La Formation Fondamentale, un Espace à Redefinir. Edited by Christiane Gohier and Suzanne Laurin. Montréal: Éditions Logiques, pp. 141-92.

Balsas, María Soledad. 2013. A imaxe dos inmigrantes galegos nos libros de texto arxentinos. Revista Galega de Educación 56: 95-98.

Balsas, María Soledad. 2014. Las Migraciones en Los Libros de Texto. Tensión Entre Globalización y Homogeneidad Cultural. Buenos Aires: Editorial Biblos. 
Benejam, Pilar. 1992. La didàctica de la geografia des de la perspectiva constructivista. Documents D'anàlisi Geográfica $21: 35-52$.

Benejam, Pilar. 1997. Las finalidades de la educación social. In Enseñar y Aprender Ciencias Sociales, Geografía e Historia en la Educación Secundaria. Edited by Pilar Benejam and Joan Pagès. España: Horsosi, pp. 33-52.

Bergamaschi, Alessandro. 2011. Attitudes et représentations sociales. Les adolescents français et italiens face à la diversité. Revue européenne des sciences sociales. European Journal of Social Sciences 49: 93-122.

Blanck, Sara. 2021. Editorial: Teaching about migration. Teachers' didactical choices when connecting specialized knowledge to pupils' previous knowledge. Journal of Social Science Education 20: 70-102. [CrossRef]

Economic and Social Council of Spain. 2019. Report Immigration in Spain: Effects and Opportunities. Madrid: Economic and Social Council of Spain.

Ernst-Slavit Gisella, Steven Morrison. 2018. “Unless You Were Native American ... Everybody Came From Another Country:" Language and Content Learning in a Grade 4 Diverse Classroom. The Social Studies 109: 309-23. [CrossRef]

Evans, Ronald. W. 1991. Concepciones del maestro sobre la historia. Boletín de Didáctica de las Ciencias Sociales 3: 61-94.

Evans, Ronald W., and David Warren Saxe, eds. 1996. Handbook on Teaching Social Issues. Washington: National Council for the Social Studies.

Fernández-Batanero, José María. 2004. La presencia de alumnos inmigrantes en las aulas: Un reto educativo. Educación y Educadores 7: 33-45.

Fien, John. 1992. Geografía, sociedad y vida cotidiana. Documents D'anàlisi Geográfica 21: 73-90.

García-Morís, Roberto, and Montserrat Oller. 2022. Enseñar y Aprender las Migraciones Forzosas en Ciencias Sociales. Magis, Revista Internacional de Investigación en Educación 5. Unpulished Work.

García-Pérez, Francisco Florencio. 2014. Ciudadanía participativa y trabajo en torno a problemas sociales y ambientales. In Una Mirada al Pasado y un Proyecto de Futuro: Investigación e Innovación en Didáctica de las Ciencias Sociales. Edited by Joan Pagès and Antoni Santisteban. Barcelona: Universitat Autònoma de Barcelona, vol. 1, pp. 119-26.

Gil, Francisco, Sandra Muzzi, and Antoni Santisteban. 2018. Todos y todas somos inmigrantes: Representaciones de niñas y niños de primaria sobre la inmigración. REIDICS: Revista de Investigación en Didáctica de las Ciencias Sociales 2: 20-35. [CrossRef]

Gil, María Encarna. 1993. Las concepciones de los alumnos sobre el tercer mundo al acabar la escolaridad obligatoria: Participación de la institución escolar en la formación, mantenimiento o refuerzo de las mismas. Didáctica de las Ciencias Experimentales y Sociales 7: 3-38.

Hammond, Thomas. 2010. "So What?" Students' Articulation of Civic Themes in Middle-School Historical Account Projects. The Social Studies 101: 54-59. [CrossRef]

Haro, María del Rosario, María Teresa Call, Montserrat Yuste, and Montserrat Oller. 2016. ¿Qué pasa con la inmigración? Una propuesta didáctica para la comprensión de la pluriidentidad. In Deconstruir la Alteridad Desde la Didáctica de las Ciencias Sociales. Educar Para una Ciudadanía Global. Edited by Carmen Rosa García, Aurora Arroyo and Beatriz Andreu. Las Palmas: AUPDCS, pp. 398-405.

Haro, María del Rosario. 2017. Una Proposta D'innovació Curricular per Treballar la Justícia Social a l'aula de Secundària: Una Reflexió Sobre la Pròpia Pràctica. Ph.D. dissertation, Universidad Autónoma de Barcelona, Bellaterra.

Hurst, David W., and E. Wayne Ross, eds. 2000. Democratic Social Education. Social Studies for Social Change. New York: Falmer Press.

Jiménez, María Dolores, Socorro Sánchez, Carmen Rosa García, and Concepción Moreno. 2002. Trabajamos la inmigración en el aula. Una experiencia desde la formación inicial de maestros y maestras. Kikiriki. Cooperación Educativa 65: 69-77.

Jodelet, Denise, ed. 1989. Les Représentations Sociales. París: PUF.

Kabunda, Mbuyi. 2017. Migraciones, derechos humanos y desarrollo. El caso africano. In Derechos Humanos, Migraciones y Comunidad Local. Andalucía: Fondo Andaluz de Municipios para la Solidaridad Internacional (FAMSI), pp. 42-53.

Le Roux, Anne. 2002. Enseigner L'histoiregéographie par le Problème? París: L'Harmatan.

Legardez, Alain. 2003. L'enseignement des questions sociales et historiques, socialement vives. Le Cartable de Clio 3: 245-53.

Legardez, Alain, and Laurence Simonneaux. 2006. L'école à l'épreuve de l'actualité. Issy-Les-Moulineaux: ESFEditeur.

Llonch, Nayra, Mireia Gonell, and Pilar Isern. 2014. Abordando las raíces migratorias en el aula: Análisis y comparativa de una misma implementación didáctica en diferentes contextos. Clío: History and History Teaching 40: 1-64.

Marolla, Jesus, and Joan Pagès Blanch. 2015. Ellas sí tienen historia. Clío E Asociados 20-21: 223-36.

McCorkle, William. 2018. The Rationale and Strategies for Undermining Xenophobia in the Classroom. The Social Studies 109: 151-66. [CrossRef]

Moscovici, Serge. 1976. La Psychanalyse, Son Image, Sonpublic. París: PUF.

Oller, Montserrat. 1999. Trabajar problemas sociales en el aula, una alternativa a la transversalidad. In Un Currículum de Ciencias Sociales Para el Siglo XXI: Qué Contenidos y Para Qué. Edited by Teresa García Santa María. La Rioja: AUPDCS, pp. $123-31$.

Oller, Montserrat. 2011. Ensenyar geografia a partir de situacions problema. Perspectiva Escolar 358: 14-23.

Olmos, Rafael, and Joan Pagès. 2017. Cambios y continuidades en las representaciones sociales de un mismo grupo de chicos y chicas sobre la crisis económica. In Investigación en Didáctica de las Ciencias Sociales. Retos Preguntas y Lineas de Investigación. Edited by Ramón Martínez, Roberto García-Morís and Carmen Rosa García. Córdoba: AUPDCS, pp. 720-29.

Olmos, Rafael, González-Monfort Neus, and Joan Pagès. 2017. Las representaciones sociales del alumnado sobre la crisis. ¿Qué soluciones ofrece el alumnado ante los problemas económicos? Didáctica de las Ciencias Experimentales y Sociales 32: 51-70. [CrossRef] 
Ortega, Delfin, and Joan Pagès. 2017. Las representaciones sociales de los problemas contemporáneos en estudiantes de magisterio de Educación Primaria. Revista Investigación en la Escuela 93: 1-15. [CrossRef]

Ortiz, Monica. 2008. Inmigración en las aulas: Percepciones prejuiciosas de los docentes. Papers: Revista de Sociología 87: $253-68$. [CrossRef]

Pagès, Joan. 1994. La didáctica de las ciencias sociales, el currículum y la formación del profesorado. Signos. Teoría y Práctica de la Educación 13: 38-51.

Pagès, Joan. 2007. La enseñanza de las ciencias sociales y la educación para la ciudadanía en España. Didáctica Geográfica 9: 205-14.

Pagès, Joan. 2016. La ciudadanía global y la enseñanza de las Ciencias Sociales: Retos y posibilidades para el futuro. In Deconstruir la Alteridad desde la Didáctica de las Ciencias Sociales. Edited by Carmen Rosa García, Aurora Arroyo and Beatriz Andreu. Las Palmas: AUPDCS, pp. 713-730.

Pagès, Joan, and Montserrat Oller. 2007. Las representaciones sociales del derecho, la justicia y la ley de un grupo de adolescentes catalanes de $4^{\circ}$ de ESO. Enseñanza de las Ciencias Sociales: Revista de Investigación 6: 3-18.

Pagès, Joan, and Antoni Santisteban. 2011a. Les qüestions socialment vives i l'ensenyament de les ciències socials. Barcelona: Servei de Publicacions de la Universitat Autònoma de Barcelona.

Pagès, Joan, and Antoni Santisteban. 2011b. Enseñar y aprender Ciencias Sociales. In Didáctica del Conocimiento del Medio Social y Cultural en la Educación Primaria: Ciencias Sociales Para Aprender, Pensar y Actuar. Edited by Antoni Santisteban and Joan Pagès. España: Síntesis, pp. 23-40.

Rodríguez-Izquierdo, Rosa María. 2009. Imagen social de los inmigrantes de los estudiantes universitarios de magisterio. Revista Complutense de Educación 20: 255-74.

Ross, Wayne, and Kevin D. Vinson. 2012. La educación para una ciudadanía peligrosa. Enseñanza de las Ciencias Sociales: Revista de Investigación 11: 73-86.

Salinas, Juan José. 2017. Transformando las Representaciones Sociales de la Participación Ciudadana Mediante la Acción Sobre Problemas Sociales de la Comunidad. Una Investigación-Acción con Estudiantes de Secundaria. Ph.D thesis, Universitat Autònoma de Barcelona, Bellaterra, Spain.

Salinas, Juan José, and Montserrat Oller. 2017. Debatiendo temas controversiales para formar ciudadanos. Una experiencia con alumnos de secundaria. Praxis Educativa 21: 40-48. [CrossRef]

Salinas, Juan José, Monterrat Oller, and Calos Muñoz. 2016. Representaciones sociales de la participación ciudadana en docentes de ciencias sociales: Perspectivas para la nueva asignatura de formación ciudadana en Chile. Foro Educacional 27: 141-61. [CrossRef]

Sant, Edda, María Teresa, asas, and Joan Pagès. 2011. Participar para aprender la democracia. Las representaciones sociales de jóvenes catalanes sobre la participación democrática. Uni-Pluri/Versidad 11: 1-25.

Santisteban, Antoni, Neus González-Monfort, Joan Pagès, and Montserrat Oller. 2014. La introducción de temas controvertidos en el currículo de ciencias sociales: Investigación e innovación en la práctica. In Historia e Identidades Culturales. Edited by Joaquin Prats, Isabel Barca and Ramón López-Facal. Barcelona: Universidad de Barcelona, pp. 310-22.

Santisteban, Antoni. 2009. Cómo trabajar en clase la competencia social y ciudadana. Aula de Innovación Educativa 187: 12-15.

Santisteban, Antoni. 2019. La enseñanza de las Ciencias Sociales a partir de problemas sociales o temas controvertidos. Estado de la cuestión y resultados de una investigación. El Futuro del Pasado: Revista Electrónica de Historia 10: 57-59. [CrossRef]

Serulnicoff, Adriana. E., and Cecilia Bernardini. 2015. Reflexiones acerca de la enseñanza de procesos migratorios a niños pequeños. Didácticas Específicas 13: 17-32.

Simonneaux, Laurence, and Alain Legardez. 2010. The epistemological and didactical challenges involved in teaching socially acute questions. Journal of Social Science Education 9: 24-35. [CrossRef]

Taboada, María Beatriz. 2016. Nación y migración: Revisión crítica de libros de texto para la enseñanza secundaria en la Argentina. Romanica Olomucensia 2: 185-202. [CrossRef]

Taboada, María Beatriz. 2018. Abordaje de sujetos migrantes y procesos migratorios en libros de texto de Ciencias Sociales. Un análisis de caso. Revista Educación 42: 20-38. [CrossRef]

Thénard-Duvivier Franck. 2008. L'enseignement des Questions Socialement Vives en Histoire et Géographie. Actes du Colloque Organisé par le SNES et le CVUH. Paris: ADAPT Editions.

Tosar, Beogan, Antoni Santisteban, Albert Izquierdo, Joan Llusá, Roser Canals, Neus González-Monfort, and Joan Pagès. 2016. La literacidad crítica de la información sobre los refugiados y refugiadas: Construyendo la ciudadanía global desde la enseñanza de las ciencias sociales. In Deconstruir la Alteridad Desde la Didáctica de las Ciencias Sociales. Educar Para una Ciudadanía Global. Edited by Carmen Rosa García, Beatriz Andreu and Beatriz Andreu. Las Palmas: AUPDCS, pp. 550-60.

Tutiaux-Guillon, Nicole. 2011. Les qüestions socialment vives, un repte per a la història i la geografía escolars. In Les Qüestions Socialment Vives $i$ L'ensenyament de les Ciències Socials. Edited by Joan Pagès and Antoni Santisteban. Barcelona: Servei de Publicacions UAB, pp. 25-39. 


\title{
The Consensus on Citizenship Education Purposes in Teacher Education
}

\author{
Marta Estellés ${ }^{1, * \mathbb{D}}$, Francisco José Amo ${ }^{2}$ and Jesús Romero ${ }^{3}$ (D) \\ 1 Faculty of Education and Social Work, The University of Auckland, Private Bag 92601 Symonds St, \\ Auckland 1150, New Zealand \\ 2 Faculty of Nursing, The University of Cantabria, 39008 Santander, Spain; franciscojose.amo@unican.es \\ 3 Faculty of Education, The University of Cantabria, 39005 Santander, Spain; jesus.romero@unican.es \\ * Correspondence: marta.estelles@auckland.ac.nz
}

Citation: Estellés, Marta, Jesús Romero, and Francisco José Amo. 2021. The Consensus on Citizenship Education Purposes in Teacher Education. Social Sciences 10: 164. https://doi.org/10.3390/ socsci10050164

Academic Editor: Delfín Ortega-Sánchez

Received: 13 April 2021

Accepted: 29 April 2021

Published: 7 May 2021

Publisher's Note: MDPI stays neutral with regard to jurisdictional claims in published maps and institutional affiliations.

Copyright: (c) 2021 by the authors. Licensee MDPI, Basel, Switzerland. This article is an open access article distributed under the terms and conditions of the Creative Commons Attribution (CC BY) license (https:// creativecommons.org/licenses/by/ $4.0 /)$.

\begin{abstract}
Although education for democratic citizenship has long been a powerful rationale for social studies education, researchers still report a significant gap between this purpose and what is really taught in classrooms. Explanations of this phenomenon vary, but literature on citizenship education (CE) research has largely interpreted this gap as a result of (preservice) teachers' political worldviews or lack of civic experiences. Other evidence, however, suggests that teacher socialization processes generate conventions about what is necessary, possible, and reasonable in CE that go beyond teachers' political views and behaviors. This mixed-method study, developed at a Spanish university, aims to explore the understandings of CE shared by preservice teachers with different political ideologies and levels of civic engagement. The findings of this study have deep implications for teacher education courses aimed at fostering CE and the curricular inclusion of current social issues.
\end{abstract}

Keywords: citizenship education; social studies teacher education; preservice teachers' perceptions; political ideology; civic engagement; mixed methods

\section{Introduction}

Although education for democratic citizenship has long been a powerful rationale for social studies education, researchers still report a significant gap between this purpose and what is really taught in classrooms (e.g., Bickmore 2014; Evans 2006; Sant 2013). To better understand the origin of teachers' reluctance toward including this purpose in the social studies curriculum, several scholars have explored teachers' perceptions on citizenship education (CE) (e.g., Brownlee et al. 2016). Studies have found that many teachers hold shallow understandings of CE and are not usually well-prepared to deal with the difficulties of engaging students in current social issues (e.g., Davies et al. 1999; Knowles and Castro 2019; Lee and Fouts 2005; Patterson et al. 2012). Similarly, studies with preservice teachers have shown that the majority of preservice teachers tend to confuse CE with moral and character education (Carr 2006; Marri et al. 2014; Martin 2010), favoring personally responsible views of citizenship (Westheimer and Kahne 2004). Some scholars have suggested that this is due to both in-service and preservice teachers having little experience in political participation (e.g., Sim et al. 2017) or holding certain political ideologies (e.g., Castro 2013; Knowles and Castro 2019). Other evidence, however, suggests that teacher socialization processes (Bullough 2000; Lortie 1975; Su 1992) generate conventions about what is necessary, possible, and reasonable in relation to $\mathrm{CE}$ that go beyond political ideologies and levels of civic engagement.

The present study delves into the CE beliefs shared by a group of Spanish preservice teachers with different political views and levels of civic engagement. The study is a continuation of a previous research focused on the teacher educators of the participants (Estelles and Romero 2019) where we found generalized, idealistic views of CE and difficulties in bringing the purposes of CE into teaching practices. The findings of this study have 
deep implications for teacher education courses aimed at fostering CE and the curricular inclusion of current social issues.

\section{Literature Review}

\subsection{From Purposes to Teaching Practices: The Challenges of Citizenship Education}

Due to the boost in popularity given to CE by supranational organizations over the last few decades, CE has been included in several national curricula worldwide (Eurydice 2012, 2017; Ramírez et al. 2007). In many European countries, the inclusion of CE has been inspired by the model of CE promoted by the European Commission (see Eurydice 2005, 2012, 2017). According to this model, CE should address four main purposes. The first purpose is to promote the political literacy of students, which includes learning about (a) socio-political institutions, national constitutions, and citizens' rights and duties; (b) both the cultural and historical heritage and the cultural and linguistic diversity of society; and (c) current social problems. The second is to develop critical thinking and analytical skills. The third is to promote the civic attitudes and values necessary for democracy. The fourth is to prepare students to actively participate in society at different levels (school, local, national, and international).

Our understanding of CE is based on the critical interpretations of this concept developed by scholars such as Ruitenberg (2015), Westheimer and Kahne (2004) and Carr $(2008,2011)$ that follow a long tradition of connecting democracy with education (Romero and Estellés 2019). For these interpretations, the critical understanding of and engagement in current social issues should be the main priorities of CE. Current research, however, suggests that these purposes of CE have not always been translated into teaching practices. Discussing public issues and promoting children's civic engagement often do not fit painlessly into conventional school traditions or what has been called the "grammar of schooling" (Tyack and Tobin 1994). As a result, these purposes are often seen by teachers as something very disconnected from their teaching goals (García and De Alba 2012; OrtegaSánchez and Pagès 2020; Reichert and Torney-Purta 2019; Roberts et al. 2019), and public issues are usually left out of the classroom (Byford et al. 2009; Hess and McAvoy 2015; Ho et al. 2017).

\subsection{Teachers' Perceptions about Citizenship Education}

The gap between the critical purposes of CE and CE teaching practice has led many educational scholars to focus on teachers' perceptions of CE (e.g., Marri et al. 2014; Martin 2010). The premise is that teachers' views on citizenship, democracy, or civic life often condition their subsequent educational practices. Several studies have found quite superficial understandings of these concepts and have interpreted this result as a serious handicap for committed CE (e.g., Castro 2013; Fry and O'Brien 2015; Marri et al. 2014; Patterson et al. 2012; Ross and Yeager 1999; Sunal et al. 2009). These studies attribute this handicap, at least partially, to certain political ideologies (e.g., Castro 2013) and/or to a general lack of civic participation experiences (e.g., Carr 2008; Sim et al. 2017).

Some studies have also explored the above relationship and suggest that teachers' political ideology and experiences have some impact on CE practices. For example, Rogers and Westheimer's (2017) quantitative study concluded that, in North America, teachers' level of political engagement is positively correlated with the frequency with which they teach about social problems such as economic inequality. Yet, they did not find any relationship between this frequency and teachers' political ideology. The mixedmethod study developed by Hess and McAvoy (2015) in the United States revealed a connection between the pedagogical approach and teachers' political views. This result was also obtained by the variable-centered analysis conducted by Gainous and Martens (2016) of the CivEd data from civics teachers from the United States. Using qualitative methods, Schugurensky and Myers (2003) interviewed a group of North American civic education teachers about their most meaningful learning experiences for teaching CE. The authors concluded that political experiences provide affective and cognitive support for 
teaching CE. Additionally, Kenyon's (2017) narrative inquiry demonstrates that the manner in which social studies teachers conceive of their relationship to the government structures "impacts the way they teach their students both about and through citizenship" (pp. 94-95).

Other evidence, however, also suggests that to understand teachers' dispositions and practical knowledge about CE, the focus cannot be exclusively on their political socialization, whether it occurs "by default" or "by design" (Lopes et al. 2009). It is also necessary to take into account that both the "grammar of schooling" (Tyack and Tobin 1994) and the "subcultures" of each school subject (Cuesta 1997; Goodson et al. 1998) implicitly delimit what is necessary, possible, and reasonable in relation to CE. As soon as CE crosses the school doors, CE is trapped and shaped by this field of forces and, often, diminished in its scope and pretensions (García and De Alba 2012). Within this framework, it is not surprising that teachers feel more confident in teaching CE when it is a distinct school subject (Alviar-Martin et al. 2008), they rarely prioritize political participation among the main aims of CE (Reichert and Torney-Purta 2019), and they frequently avoid teaching about controversial issues in the classroom (Byford et al. 2009; Ho et al. 2017; McAvoy and Hess 2013).

When asked, teachers who prefer not to introduce current social issues in the classroom argue that it is due to its highly politicized nature and the age of their students (McAvoy and Hess 2013, p. 34). The beliefs underlying these reasonings include both that the teacher must be neutral-leaving out ideological interpretations-and that students are too naïve and manipulable. The illusion of neutrality in education (Apple 2008; Ross 2017) and protectionist views of childhood innocence (Wyness 2006) are often present in both liberal and conservative political views (Estelles and Romero Forthcoming). These types of assumptions usually go beyond the explicit ideology of teachers and are part of what Bourdieu (1999) calls the doxa. These assumptions underpin our own common sense (Wagner et al. 2011) and play a key role in our "practical knowledge" (Bourdieu 2007).

To reduce the gap between the critical purposes of CE and CE teaching practice, we need to understand the conventions of CE that go beyond the explicit will and intentions of teachers (Estelles and Romero 2019; Bougher 2014; Fischman and Haas 2012). For this reason, the present study aims to explore the CE understandings that remain beyond ideological discrepancies and civic engagement. This study was conducted with preservice teachers enrolled in a Spanish public university, and it addresses the following key questions:

- What are preservice teachers' political ideologies and levels of civic engagement?

- Which understandings of CE are shared by preservice teachers with different political ideologies and levels of civic engagement?

\section{Methods}

\subsection{Research Design}

This study used an explanatory sequential mixed-method design, which implies "collecting and analyzing first quantitative and then qualitative data in two consecutive phases within one study" (Ivankova et al. 2006, p. 4). The aim of the quantitative phase was to provide a general understanding of preservice teachers' political ideology and civic engagement (i.e., to answer Research Question 1) and to select a smaller sample for a second qualitative phase aimed at deeply exploring the understandings of CE that seem to elicit more consensus among a group of participants with different political ideologies and levels of civic engagement (Research Question 2).

\subsection{Study Context and Participants}

The study was conducted in a Spanish medium-sized public university that offers early childhood education and primary education teaching programs. An independent sampling approach for each phase of the study was used (Curry and Nunez-Smith 2015).

For the quantitative phase, participants were selected using a simple random sampling. Microsoft Excel software was used to conduct the random selection. The inclusion criterion 
used was part-time or full-time enrolment in the early childhood education or primary education teaching programs. The target population of the study was 1335 students enrolled in the previously mentioned teaching programs during the 2017/18 academic year. In order to have sufficient statistical power to detect the associations of interest, a sample size of $n=299$ was obtained from considering a $95 \%$ confidence level, a precision of $5 \%$, and a variance of 0.5 . After determining the sample size, a $10 \%$ loss rate was applied, resulting in a final sample size of 334 participants. Finally, a total of 324 student teachers agreed to participate in the study.

For the qualitative phase, as the aim was to explore common understandings of $\mathrm{CE}$ among preservice teachers with different political ideologies and levels of civic engagement, the authors selected a purposeful sample from the quantitative strand. Participants from the different categories related to their political ideology (liberal, moderate, and conservative) and level of civic engagement (low, moderate, and high engagement) were chosen. Selection criteria were also established to include preservice teachers from both teaching programs (early childhood education and primary education), all levels (from first-year to fourthyear students), and a representative proportion of sexes. The total number of preservice teachers who participated in the qualitative strand $(n=27)$ was based on the achievement of saturation (O'Reilly and Parker 2012).

\subsection{Instruments for Data Collection}

The instrument used for the quantitative phase was an online questionnaire that included questions about preservice teachers' background information, self-reported political ideology, and civic engagement. This questionnaire was an adapted version of the questionnaire used by Rogers and Westheimer (2017). Following Rogers and Westheimer's (2017) work, participants' self-reported political ideology was assessed by the question: 'How would you characterize yourself?' (very liberal, somewhat liberal, moderate, somewhat conservative, or very conservative). As measured by Rogers and Westheimer (2017), civic engagement was a composite variable that considered participants responses to questions about the frequency with which they follow political news, talk about politics with family and friends, and participate in organizations that aim to make a difference in their community or broader society:

How often (never, once or twice, monthly, weekly, or a few times a week/daily) have you:

- (Civic Item 1) followed news by reading a newspaper or news magazine, watching national news on TV, listening to news on the radio, or reading news online?

- (Civic Item 2) talked about politics or government with your family or friends?

- (Civic Item 3) participated in an organization that tries to make a difference in your community or broader society?

Following Rogers and Westheimer (2017), the answers were coded as: never $=0$; once or twice $=1$; monthly $=2$; weekly $=4$; a few times a week $/$ daily $=8$. Responses were entered into the following formula, which ascribed more weight to Civic Item 3 :

$$
((\text { Civic Item } 1+\text { Civic Item } 2+(2 \times \text { Civic Item } 3))) / 4
$$

The result was then categorized according to the following ranges: $0-3.5=10 \mathrm{w}$ engagement, $4.0-5.5=$ moderate engagement, and 6-8 = high engagement.

For the second phase of the study, qualitative data were collected through visual interviews. We used photo-elicitation techniques to elicit intuitive beliefs about CE. The visual images used during the interviews were researcher-generated (Prosser 2007; Richard and Lahman 2015). Preservice teachers were required to view and comment on the images and sentences that corresponded to each dimension/purpose of CE considered by the Eurydice Reports (see Table 1). 
Table 1. Description of the images used in the visual interviews in relation to the different dimensions of CE.

\begin{tabular}{|c|c|c|}
\hline Purposes/Dimensions of Citizens & ip Education (Eurydice 2005, 2012, 2017) & Stereotype Image Used in the Interview \\
\hline \multirow{5}{*}{ Political Literacy } & Social, political, and civic institutions & $\begin{array}{c}\text { Textbook page describing Spanish political } \\
\text { institutions }\end{array}$ \\
\hline & Social issues & $\begin{array}{l}\text { Teacher in a medical consultation with a burned } \\
\text { head from discussing controversies in class }\end{array}$ \\
\hline & National constitutions and laws & Legal texts and the Spanish Constitution \\
\hline & Cultural and historical heritage & $\begin{array}{l}\text { Children dressed up with traditional costumes in } \\
\text { a Spanish regional festivity }\end{array}$ \\
\hline & $\begin{array}{l}\text { Cultural and linguistic diversity of } \\
\text { society }\end{array}$ & A school celebrating the Day of the Nations \\
\hline $\begin{array}{l}\text { Critical Thinking and Analytical } \\
\text { Skills }\end{array}$ & & $\begin{array}{l}\text { A student in a class asking her teacher to teach } \\
\text { them to think, not to memorize }\end{array}$ \\
\hline \multirow{3}{*}{ Attitudes and Values } & Respect & A poster with the rules of a classroom \\
\hline & Solidarity & Children helping each other in class \\
\hline & Learning to listen and resolve conflicts & Two children angry with each other \\
\hline \multirow[t]{2}{*}{ Active Participation } & $\begin{array}{c}\text { Practical experience of democracy at } \\
\text { school }\end{array}$ & $\begin{array}{c}\text { Young children discussing as a group in a } \\
\text { classroom }\end{array}$ \\
\hline & $\begin{array}{l}\text { Involving students in the community at } \\
\text { local, national, and international levels }\end{array}$ & $\begin{array}{l}\text { Children taking part in a demonstration against } \\
\text { racism and xenophobia }\end{array}$ \\
\hline
\end{tabular}

We selected images and sentences that directly appealed to the common sense understanding of CE-frequently in the form of stereotypes-based on previous research on the topic. For example, we used a photo of a school celebrating the Day of the Nations to capture the participants' ideas about the dimension of "respect for cultural and linguistic diversity", as in Spanish schools this goal is often reduced to a mere stereotyped representation of the dominant cultures of other countries (Torres 2011). We also included a photo of children dressed in traditional and folk costumes of the Autonomous Community where they live to trigger the participants' beliefs about "the promotion of the recognition of cultural and historical heritage", because these folkloric symbols have become useful for the Autonomous Communities in Spain to promote territorial identities (Martín 2001). For the dimension related to the teaching of political issues in the classroom, we chose to use the sentence "politics is very important for a citizen, but it might be too complex and conflictive to address with children at schools", and a vignette of a teacher with a burned head whose doctor is asking if they had dared to discuss controversial issues in the classroom. These texts contain arguments that teachers often use to avoid teaching political issues in the classroom (Hess and McAvoy 2015; Ho et al. 2017).

\subsection{Data Analysis}

\subsubsection{Quantitative Data Analysis}

Descriptive statistics were used to describe the main characteristics of the sample, the participants' self-reported political ideology and the prevalence of low, moderate, and high civic engagement. Verification of normality of quantitative variables was performed with the Shapiro-Wilk test. The chi-squared test was applied to assess whether there were significant differences between males and females in the following variables: year level, civic engagement, participation in organizations, following the news, and talking about politics. This test was also used to check whether there were differences in the distribution of civic engagement among different teaching programs and ideological categories. Fisher's exact test was employed to examine differences in civic engagement between males and females and among different year levels. The Student's $t$-test with Welch's correction was employed to assess whether age differences existed between sexes. Finally, a logistic regression model was developed to identify the contribution of some variables to civic engagement. Adjusted ORs and their confidence intervals were calculated for the included variables. Statistical procedures were conducted using the R 3.3.1 software along with R Studio. 


\subsubsection{Qualitative Data Analysis}

The qualitative data analysis was iterative and included both inductive and deductive analysis (Bogdan and Biklen 2007). We used Atlas.ti software (ATLAS.ti Scientific Software Development $\mathrm{GmbH}$, Berlin, Germany) for data codification. Analysis began by open coding the visual interview transcriptions. Then, we looked for categories, patterns, and themes related to CE across participants with different political ideologies and levels of civic engagement. In particular, we focused on the reasons and rationales that the participants provided to justify the importance of $\mathrm{CE}$ and its different dimensions. For this process, we drew upon the different dimensions of CE described by the Eurydice reports (Eurydice 2012, 2017) and the framework developed by Carr $(2008,2011)$ that distinguishes between 'thin' and 'thick' approaches to education for democracy (see Table 2). This approach to qualitative data analysis based on the themes that emerged from the data and the relationship between the data and pre-existing categories provided us with a deep understanding of how preservice teachers articulate their CE beliefs, increasing this study's internal validity (Maxwell 2013).

Table 2. Framework used for the qualitative data analysis.

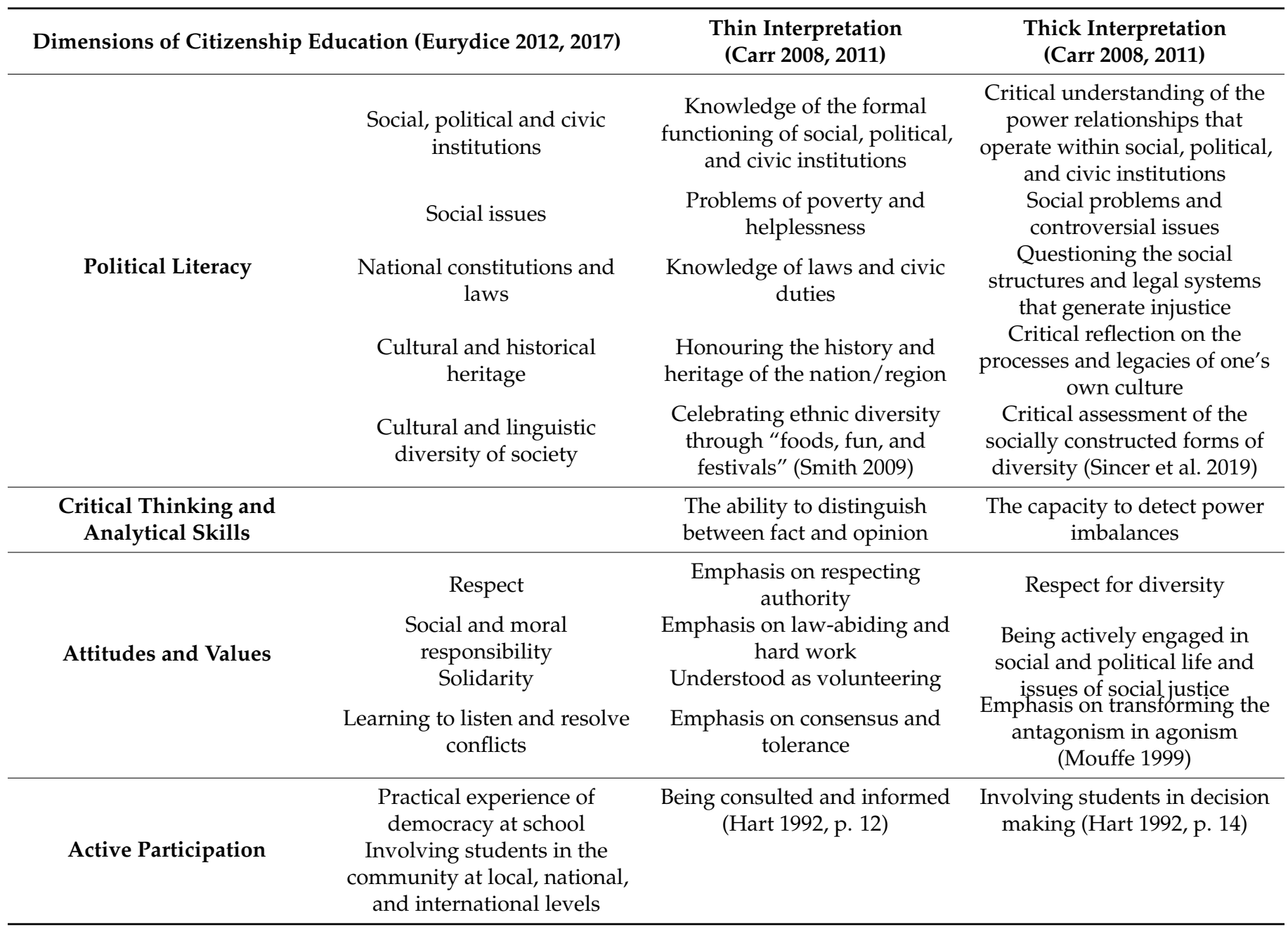

\subsection{Ethical Considerations}

Ethical issues were carefully contemplated in this study due to the sensitivity of the topic. Participants were informed about the objectives and procedures of the study and how their rights were going to be protected. Participation in the research was voluntary and anonymous. The preservice teachers who freely agreed to collaborate in the study 
signed an informed consent form and they were asked for feedback on the transcriptions of the interviews. The study has the ethical approval of the Ethics Committee of the University of Cantabria [Project No. 07/2017].

\section{Findings}

\subsection{Quantitative Results: Political Ideology and Civic Engagement}

The main characteristics of the sample and quantitative results are described in Table 3. As can be seen in this Table, 268 females (82.7\%) and 56 males (17.3\%), aged between 17 and 44 years old, participated in the study. Participants were evenly distributed among the four years of the primary education $(57.1 \%)$ and early childhood education (42.9\%) teaching programs.

Table 3. Quantitative descriptive results.

\begin{tabular}{|c|c|c|c|c|c|c|}
\hline \multirow{3}{*}{$\begin{array}{c}\text { Variable } \\
\text { Age (years) }\end{array}$} & \multirow[b]{3}{*}{ Mean, SD } & \multicolumn{4}{|c|}{ Sex } & \multirow{3}{*}{$\begin{array}{c}p \\
0.693\end{array}$} \\
\hline & & \multicolumn{2}{|c|}{$\begin{array}{c}\text { Male } \\
(\mathrm{n}=56)\end{array}$} & \multicolumn{2}{|c|}{$\begin{array}{c}\text { Female } \\
(\mathrm{n}=268)\end{array}$} & \\
\hline & & 21.9 & 4.1 & 21.6 & 3.9 & \\
\hline \multirow{5}{*}{ Year Level (n)\% } & Category & & & & & \multirow{5}{*}{0.434} \\
\hline & First & 20.0 & 35.7 & 68.0 & 25.4 & \\
\hline & Second & 15.0 & 26.8 & 79.0 & 29.5 & \\
\hline & Third & 11.0 & 19.6 & 57.0 & 21.3 & \\
\hline & Fourth & 10.0 & 17.9 & 64.0 & 23.9 & \\
\hline \multirow[t]{3}{*}{ Teaching Program (n)\% } & Category & & & & & \\
\hline & Early childhood education & 60 & 10.7 & 133.0 & 49.6 & \multirow[b]{2}{*}{$<0.001$} \\
\hline & Primary education & 50.0 & 89.3 & 135.0 & 50.4 & \\
\hline \multirow{6}{*}{ Ideology (n)\% } & Category & & & & & \multirow{6}{*}{0.449} \\
\hline & Very liberal & 10.0 & 18.2 & 39.0 & 15.0 & \\
\hline & Somewhat liberal & 11.0 & 20.0 & 72.0 & 27.7 & \\
\hline & Moderate & 25.0 & 45.5 & 108.0 & 41.5 & \\
\hline & Somewhat conservative & 9.0 & 16.4 & 32.0 & 12.3 & \\
\hline & Very conservative & 0.0 & 0.0 & 9.0 & 3.5 & \\
\hline \multirow{6}{*}{$\begin{array}{l}\text { Follows Political News } \\
\text { (n) } \%\end{array}$} & Category & & & & & \multirow{6}{*}{0.684} \\
\hline & Never & 5.0 & 8.9 & 16.0 & 6.0 & \\
\hline & Once or twice & 5.0 & 8.9 & 39.0 & 14.6 & \\
\hline & Monthly & 14.0 & 25.0 & 76.0 & 28.4 & \\
\hline & Weekly & 10.0 & 17.9 & 46.0 & 17.2 & \\
\hline & Daily or almost daily & 22.0 & 39.3 & 91.0 & 34.0 & \\
\hline \multirow{6}{*}{ Talks about Politics (n)\% } & Category & & & & & \multirow{6}{*}{0.462} \\
\hline & Never & 3.0 & 5.4 & 26.0 & 9.7 & \\
\hline & Once or twice & 22.0 & 39.3 & 118.0 & 44.0 & \\
\hline & Monthly & 10.0 & 17.9 & 54.0 & 20.1 & \\
\hline & Weekly & 13.0 & 23.2 & 46.0 & 17.2 & \\
\hline & Daily or almost daily & 8.0 & 14.3 & 24.0 & 9.0 & \\
\hline \multirow{6}{*}{$\begin{array}{c}\text { Participates in } \\
\text { Organizations (n)\% }\end{array}$} & Category & & & & & \multirow{6}{*}{0.521} \\
\hline & Never & 3.0 & 5.4 & 12.0 & 4.5 & \\
\hline & Once or twice & 31.0 & 55.4 & 173.0 & 65.5 & \\
\hline & Monthly & 11.0 & 19.6 & 31.0 & 11.7 & \\
\hline & Weekly & 8.0 & 14.3 & 32.0 & 12.1 & \\
\hline & Daily or almost daily & 3.0 & 5.4 & 16.0 & 6.1 & \\
\hline \multirow{4}{*}{ Civic Engagement (n)\% } & Category & & & & & \multirow{4}{*}{0.672} \\
\hline & Low & 43.0 & 76.8 & 216.0 & 81.8 & \\
\hline & Moderate & 9.0 & 16.1 & 32.0 & 12.1 & \\
\hline & High & 4.0 & 7.1 & 16.0 & 6.1 & \\
\hline
\end{tabular}


As can be seen in Table 3, most participants had a moderate ideology $(45.5 \%$; $95 \%$ confidence interval [CI]: 36.9-47.7), followed political news every day (39.3\%; 95\% CI: 29.9-40.2), talked very infrequently about politics (39.3\%; 95\% CI: 37.9-48.7), and had participated once or twice in a social organization (55.4\%; 95\% CI: 58.3-68.8). There were no significant differences between males and females in any of these cases.

In relation to the distribution of civic engagement, most participants showed low civic engagement (76.8\%; 95\% CI: 76.3-84.9). Forty-one participants had a moderate civic engagement (16.1\%; 95\% CI: 9.6-16.9), and 20 participants had a high civic engagement (7.1\%; 95\% CI: 4.1-9.5). No significant differences were found between male and female civic engagement $(p=0.578)$. Civic engagement was not age-related either $(p=0.588)$. There is, however, a correlation between year level and civic engagement $(p=0.032)$; there were significantly less participants with low civic engagement in the third year than in the other year levels (see Table 3). A relationship between teaching program and civic engagement was also found; high civic engagement was recorded at seven percentage points higher in the primary education program than in the early childhood education program $\left(2.2 \%\right.$ vs. $\left.9.2 \% ; \chi^{2}=5.46, \mathrm{df}=1, p=0.020\right)$. Finally, self-reported political ideology and civic engagement were not related $(p=0.233)$. Yet, the greatest engagement was found in those participants who self-identified as very liberal $(36.8 \%)$, and the highest prevalence of low and moderate civic engagement was found among those participants that described themselves as politically moderate $(45.1 \%$ and $34.1 \%$, respectively).

The results obtained with the logistic regression model are presented in Table 4 . This Table shows the adjusted odds ratios (ORs) of the included variables and their confidence intervals. The analysis reveals that those participants who were enrolled the primary education program are 3.6 times more likely to have a high civic engagement than participants from the early childhood education program. Compared to the participants enrolled in the first year, third-year participants are 3.1 times more likely to have high civic engagement. Additionally, participants identified as conservative are four times less likely to have high civic engagement compared to the participants who described themselves as liberal.

Table 4. Logistic regression model.

\begin{tabular}{ccccccc}
\hline & & \multicolumn{3}{c}{$\mathbf{9 5 \%} \mathbf{C I}$} & & $\mathbf{9 5 \%} \mathbf{C I}$ \\
\cline { 3 - 7 } Factor & $\boldsymbol{\beta}$ & Inf & Sup & OR & Inf & Sup \\
\hline Intercept & -3.54 & -5.94 & -0.92 & 0.03 & 0.00 & 0.40 \\
Sex (Female) & 0.16 & -0.80 & 1.24 & 1.17 & 0.45 & 3.46 \\
Age & 0.02 & -0.09 & 0.11 & 1.02 & 0.91 & 1.12 \\
Primary & 1.27 & 0.35 & 2.33 & $* 3.57$ & 1.42 & 10.31 \\
Second Year & -0.25 & -1.51 & 0.99 & 0.78 & 0.22 & 2.70 \\
Third Year & 1.13 & 0.06 & 2.30 & $* 3.10$ & 1.06 & 9.95 \\
Fourth Year & 0.04 & -1.27 & 1.35 & 1.04 & 0.28 & 3.85 \\
Moderate & -0.66 & -1.51 & 0.16 & 0.52 & 0.22 & 1.17 \\
Conservative & -1.38 & -3.28 & -0.02 & $* 0.25$ & 0.04 & 0.98 \\
\hline
\end{tabular}

${ }^{*} p<0.05$. OR: odds ratio; CI: confidence interval. Inf: inferior. Sup: superior.

\subsection{Qualitative Results: The Consensus about Citizenship Education}

When reflecting on the photographs, the interviewed preservice teachers mentioned a broad range of reasons to justify the need for $\mathrm{CE}$. All the preservice teachers agreed that $\mathrm{CE}$ should be an essential school mission. The reasons, which are summarized and exemplified in Table 5, included the need to be informed, preserve traditions, obey laws, respect diversity, and participate in decision-making, among others. As can be seen in Table 5, the reasons mentioned by the preservice teachers could be categorized into the four dimensions of CE described by the Eurydice reports (Eurydice 2012, 2017). However, the attention given to each dimension was variable. The most highlighted dimension was the dimension related to attitudes and values. Some aspects of the political literacy dimension such as the knowledge of local and regional traditions were also highly regarded. However, other 
aspects of this dimension such as the teaching of current social issues or civic institutions did not arouse much enthusiasm among the preservice teachers interviewed, nor did the critical thinking skills dimension that was only mentioned by one participant. The references made to the participative dimension were mainly focused on student participation in the classroom and the importance of using active teaching methods and democratic processes to encourage this participation.

Table 5. CE dimensions and reasons for advocating CE.

\begin{tabular}{|c|c|}
\hline CE Dimensions & Reasons for Advocating CE \\
\hline \multicolumn{2}{|l|}{ Political Literacy } \\
\hline Knowledge About Civic Institutions & $\begin{array}{l}\text { Quotes mentioning the importance of teaching } \\
\text { children about civic institutions to value their role } \\
\text { in a democratic society. }\end{array}$ \\
\hline Political and Social Issues & $\begin{array}{l}\text { Quotes advocating for the inclusion of current } \\
\text { political and social issues in the classroom to } \\
\text { engage children in their potential solution. }\end{array}$ \\
\hline Cultural Heritage & $\begin{array}{l}\text { Quotes refering to the importance of children } \\
\text { knowing about cultural traditions and symbols to } \\
\text { preserve their heritage. }\end{array}$ \\
\hline \multicolumn{2}{|l|}{ Attitudes and Values } \\
\hline Obedience/Responsibility & $\begin{array}{l}\text { Quotes pointing to the importance of children } \\
\text { learning to respect social norms and taking } \\
\text { responsibility for their own behavior. }\end{array}$ \\
\hline Tolerance/Respect & $\begin{array}{c}\text { Quotes indicating the importance of children being } \\
\text { respectful to others. }\end{array}$ \\
\hline Respect for Cultural and Linguistic Diversity & $\begin{array}{l}\text { Quotes pointing to the importance of children } \\
\text { being respectful to other cultures and languages. } \\
\text { Quotes highlighting the importance of children }\end{array}$ \\
\hline Conflict Solving/Discussion & $\begin{array}{l}\text { learning how to discuss ideas and peacefully solve } \\
\text { discrepancies through dialogue. }\end{array}$ \\
\hline \multicolumn{2}{|l|}{ Analytical Skills } \\
\hline Provide Reasons for Their Ideas & $\begin{array}{l}\text { Quotes refering to the importance of children } \\
\text { reflecting on their own ideas and being able to } \\
\text { defend them. }\end{array}$ \\
\hline Avoid Manipulation & $\begin{array}{l}\text { Quotes mentioning the importance of developing } \\
\text { children's analytical thinking skills to avoid } \\
\text { manipulation. }\end{array}$ \\
\hline \multicolumn{2}{|l|}{ Active participation } \\
\hline $\begin{array}{c}\text { Participation in Classroom Management and } \\
\text { Organization }\end{array}$ & $\begin{array}{l}\text { Quotes highlighting the virtues and/or the } \\
\text { importance of making children participants of the } \\
\text { classroom management and organization. }\end{array}$ \\
\hline Participation in Social and Political Activities & $\begin{array}{c}\text { Quotes highlighting the virtues and/or the } \\
\text { importance of engaging children in social and } \\
\text { political activities that occur beyond the school } \\
\text { walls. }\end{array}$ \\
\hline
\end{tabular}

From the analysis of the rationales provided by the participants to justify these dimensions, four common themes were identified in the interviews of preservice teachers with different political ideologies and levels of civic engagement: (a) values education at the core of $\mathrm{CE}$, (b) cultural heritage as the main goal of $\mathrm{CE}$, (c) political literacy education through teaching factual events, and (d) children unable to think critically and participate. 


\subsubsection{Values Education at the Core of Citizenship Education}

As mentioned before, the most highlighted dimension of $C E$ was attitudes and values. This dimension was highly regarded by most of the preservice teachers interviewed (24 out of 27), especially in the following aspects: learning to behave responsibly (23 participants), strengthening a sense of respect and solidarity (19 participants), and learning to resolve conflict peacefully (16 participants). Accordingly, the words values, respect, tolerance, solidarity, and responsibility were frequently raised in the interviews. References to the issue of living together (consensus, dialogue, social norms, etc.) were also abundant, especially when they were exposed to the image of a school celebrating the Day of the Nations. Most of the interviewees (24 out of 27) defended the importance of values education while criticizing teacher-centered instruction based on memorization of factual information. They argued that CE involves something else other than the mere transmission of civic knowledge; that is, the promotion of certain values and attitudes. This idea was reflected through many expressions: "Of course, it's important to know what a democracy is and what the Congress does, but there is no point in teaching all that if they [students] aren't tolerant, don't respect the norms, and don't care about others". During the interviews, only one participant emphasized the importance of civic knowledge:

Here I see the Congress and the Senate and ... Well, I believe CE is necessary because it helps children to know about all these institutions where important decisions are made. It is necessary because, unfortunately, we have no idea of how they work.

Regardless of the participants' political ideology, they tended to idealize the power of values education through references to the future and social salvation. As Sandra (conservative and high engagement) and Maria (moderate and low engagement) stated, respectively:

It seems that people do not realize that for solving the problems that our country has, it's necessary to educate children in values because if you don't educate them from childhood, then it is very difficult to change them, unfortunately.

Education is everything because the children you educate will be soon the future of the country ... You must educate them from early childhood and teach them values. If everyone had a set of common values of respect, tolerance, etc., there would be no terrorism, hatred, none of that.

Even for the most liberal and highly engaged participants, when firstly described, CE was frequently associated to values: "for me, educating for citizenship means educating in democratic values such as respect, participation, and solidarity" (Carlos, liberal and high engagement). The specific values the participants supported differed (i.e., conservative participants tended to put more emphasis on honesty and law-obedience, while liberal participants usually focused more on respect and solidarity), but the redemptive narrative remained beyond ideologies. The idea of moral education as an essential mission of schools was not questioned by any preservice teacher, and only one participant acknowledged its limitations when they recognized that critical thinking skills were also necessary to exercise citizenship.

Additionally, the issue of values was generally related to the ideal of convivencia ${ }^{1}$-living together in harmony (Hernando-Lloréns 2019), understanding CE as a practice of peacekeeping. For this reason, terms such as consensus, dialogue, tolerance, respect for social norms, and harmony were abundant in both liberal and conservative participant interviews. For example, note the following quotes from participants with opposite ideological positions:

I think CE is necessary because students are part of an educational community with teachers, families, etc., and it's important to value that coexistence and to comply with established norms. Values are necessary to live together in harmony. (Francisco, conservative and low engagement) 
I believe that $\mathrm{CE}$ also involves students and the teacher agreeing on rules of coexistence through dialogue and taking responsibility for compliance. (Ana, liberal and high engagement).

When discussing how to bring values education into teaching practices, the participants made some generic references to the use of active teaching methods to promote student participation in the classroom:

To teach citizenship and values, students need to be active and to participate in the classroom. We cannot teach them through direct instruction, giving lessons with textbooks and doing exams. (Alberto, moderate and low engagement).

In CE children need to learn how to respect each other's turn to speak, to respect their partner, to respect their partners' opinions ... Children can only learn that if they participate in class and have opportunities to speak up. (Ana, liberal and high engagement).

Despite this emphasis on participation, most preservice teachers did not interpret the image of a group of children arranged in a circle/assembly with some hands raised as a space of participation, but rather as evidence of good manners.

Beyond political discrepancies, the preservice teachers interviewed also generically mentioned the importance of the teacher acting as a good role model in values education and CE:

To teach all those democratic values, the teacher must, first of all, teach through example. You cannot ask your students to be respectful if you are not respectful with them. (Alejandra, moderate and high engagement).

\subsubsection{Cultural Heritage as the Main Goal of Citizenship Education}

Another common theme among participants with different ideological positions and levels of civic engagement was the defence of teaching of the cultural and historical heritage of the local region. Most participants (25 out of 27) agree that CE should promote the knowledge of local and regional traditions. The photo of some children dressed up with traditional costumes in a regional festivity inspired feelings of tenderness and aroused enthusiastic reactions among all participants: "it's very nice to see children participate in these activities because it is a shame that these customs get lost and that they forget where they come from" (Pilar, conservative and low engagement). For some, this image evoked memories from their childhood and a bucolic image of traditional country life:

I remember when I was little, and we prepared the town festivities at school, and everyone in town helped us with the costumes. Everyone participated in some way because we all knew each other. It is a shame that children in cities do not know this. So I think CE should try to rescue all this. (Carlos, liberal and high engagement).

Others explicitly recognized that the image accurately represents what CE means for them, with exclamations such as: "for me, this is really educating for citizenship", "that's what CE is about, right? Knowing where we come from, our roots, to know who we are" and "in the end, I think this must be the main purpose of $\mathrm{CE}$, that we learn to appreciate where we come from and worry about taking care of it". As can be observed in these quotes, there is a generalized admiration for the culture and traditions of the region. This admiration not only caused that the stereotyped image of country life to not raise any criticism among the participants, but also the construction of historical knowledge and the goals of CE to be subject to the construction of territorial identities. "Knowing our roots to know who we are" becomes here a more important goal than prior invocations to respect, tolerance, and convivencia. Not surprisingly, diversity at this point of the interview was totally forgotten.

The image of the children wearing traditional costumes was shown a few photographs after the image of a school celebrating the Day of the Nations depicting a very stereotyped 
representation of the dominant cultures of other countries. As explained above, the image of a school celebrating the Day of the Nations also aroused admiration among the participants. All preservice teachers seemed to agree with activities such as celebrating the Day of Nations, as they promote "respect for other cultures" and "the relativization of our own cultural customs". However, no tensions were perceived between the preservation of the regional culture and respect for diversity and the issue of living together. The generalized reaction to both photographs shows that the preservice teachers interviewed hold stereotyped and essentialist views of human cultures.

\subsubsection{Political Literacy Education through Teaching Factual Events}

The debate around the political literacy dimension was mostly focused on whether to include political and social issues in the classroom. In this debate, only four (out of 27) preservice teachers advocated for including political and social issues in early childhood and primary schools. This opinion does not seem to be associated with any particular ideology: two of these preservice teachers were liberal, one moderate, and one conservative. However, all of them were highly engaged in politics (although not all the participants who were highly engaged shared this belief). The reasons these participants provided to support their opinion ranged from the need to be informed about current issues through to the importance of increasing youth interest in politics to keep democracy alive. As one of the participants stated:

I don't know why CE is not used to talk more about what is happening in Catalonia, for example, and less about the Constitution, the laws, and this kind of thing. We have no idea about that (Catalonia's independence issue), even though it is every day in the news, in the TV ... and I don't know what to think about it! (Lorea, liberal and high engagement).

Most of the participants, however, did not advocate for the inclusion of this type of topic in the classrooms. As one of these preservice teachers said:

I completely agree with this sentence (politics is very important for a citizen, but it may be too complex and conflictive to address with children in early childhood and primary education]. Politics is a very important issue nowadays, especially at older ages, as citizens. But recognizing that it is very important does not mean that it should be included in CE classes with such young children in early childhood and primary education. I think it's okay to teach it from secondary education.

There were three main reasons provided by the participants who were reluctant to include political issues in the classroom: (a) that these issues are too controversial and, therefore, it is very difficult for a teacher to teach them from a neutral perspective, (b) that these issues are not suitable for young children, and (c) that these issues are too complex. We will further explain the second and third arguments in the next section. The first argument reveals a notion of knowledge as an "object" divorced from politics and, therefore, free from bias and suspicion. From this perspective, teachers should be neutral, leaving politics outside the classroom and teaching facts. For example, note the following claims of both liberal and conservative preservice teachers:

I think we should know more about politics when we leave school, but, of course, it is very complicated because political issues are very contradictory, some say one thing and others another ... So, yes, I think it's too conflicting. (Daniel, liberal and low engagement)

It's true that there are issues in politics that are a bit tricky and that maybe it's better not to address ... I think we have to teach them (students) what democracy is, how it works, what types of democracies there are, what are the differences between a dictatorship and a democracy ... and all that, which is more objective. (Carmen, conservative and low engagement) 
Some preservice teachers with different political ideologies and levels of civic engagement also believed that political issues should be left out of the classroom because their highly emotional component impedes treating these issues as an "object to be taken in with minimal subjective interference" (Ross 2017, p. 11). As one of the participants claimed: "The problem is that these issues cannot be studied with a minimum of rigor because emotions are running very high. So it's better to treat them indirectly, making connections with other contents of the curriculum" (Alberto, moderate and low engagement). As another preservice teacher suggested: "You have to be very apolitical. If not, it is impossible to treat them from a neutral perspective" (Francisco, conservative and low engagement).

Two students also argued that these topics can cause conflicts and controversies that disturb the peace and stability of the classroom, setting students against each other:

The problem is that these topics can accentuate the differences between some students and others. I believe that what we have to do is to generate mutual understanding, convivencia, and not conflict and disagreement. (Alejandra, moderate and high engagement)

\subsubsection{Children Unable to Think Critically and Participate}

One of the most commonly used arguments by both liberal and conservative participants for leaving political issues out of the classroom is that children are too young (innocent, manipulable, immature, etc.) to understand the complexity of political affairs. See, for instance, the following quotes:

I believe that politics at this age is not important because it does not really influence them (children) and they are not aware of what is happening, they are too naïve. (Sandra, conservative and high engagement).

I think it (politics) is a very conflictive and complex issue for such young children, maybe not in secondary school ... I don't know ... Maybe it's better to let them enjoy childhood and not disturb them with this mud of adults. (Cristina, liberal and low engagement).

The metaphor used by this participant to describe "politics" is representative of the perceived opposition between the world of children (joyful, pure, and innocent) and the world of adults (political, stained, and muddy). This opposition also appears in other interviews made by participants with a different self-reported ideology: "I believe that politics is so corrupt, so complex that it is better to keep children away from it" (Maria, moderate and low engagement). Additionally, a simple/complex dichotomy related to the previous opposition of the child/adult world appears in these interviews. As one of the preservice teachers said: "I don't think we have to discuss politics with children because ... what is politics really? what does it do? Children don't understand that" (Pilar, conservative and low engagement). Interestingly, many preservice teachers (15 out of 27) recognized that they do not feel comfortable dealing with political affairs because they do not have enough knowledge about it: "To be honest with you, I don't understand much about politics and I wouldn't know how to teach it in a primary classroom" (Alberto, moderate and low engagement). Whether liberal, moderate, or conservative, the majority of these preservice teachers had low levels of civic engagement.

The protectionist view of childhood can also be indirectly observed in the omission of children's social and political participation by most of the preservice teachers interviewed (25 out of 27). Only two participants reacted positively to the photograph of some children taking part in a demonstration against racism and xenophobia, and they were both liberal and high engagement. However, for two other interviewees with this same profile, the image aroused surprise and rejection. See, for instance, the following quotes: "This is a sad thing, it's sad that children have to go out and demonstrate because adults don't know how to solve these problems, it's a shame, it's very cruel" (Ana, liberal and high engagement); "I am angry to see that children have to go to the streets to demonstrate because we don't do it. They shouldn't have to do this, you know?" (Carlos, liberal and high engagement). 
These participants' disagreement with children's involvement in public demonstrations contrasts with their claims for more student participation in the classroom and school life. For example, when they were shown the image of a group of children discussing in a circle in a classroom, these participants mentioned the importance of using active teaching methods and democratic processes to encourage student participation: "In this image, I can see an assembly where children are deciding, probably, on the rules of the class. I like this because it allows them to debate, participate, and commit more. Schools should offer more opportunities for democracy" (Carlos, liberal and high engagement).

\section{Discussion}

Although there are a few studies that delve into the relationship between teachers' political ideologies and their dispositions toward different dimensions of CE (e.g., Knowles 2018; Rogers and Westheimer 2017), a general picture of both preservice and in-service teachers' political ideologies and levels of civic engagement is still lacking. The ideology of the participants of this study is similar to that found by the Spanish Youth Institute (INJUVE 2017) for the population of young Spanish people. The percentage of participants with a moderate ideology $(42 \%)$ is only three percentage points lower than their age group average, the proportion of liberal (38.2\%) is five percentage points higher, and the presence of conservative $(16.4 \%)$ is three percentage points lower. The frequency with which the participants follow political news and talk about politics does not differ greatly from those of their generation either (INJUVE 2017, pp. 13-16). The low levels of civic engagement that the preservice teachers showed were not unexpected considering those of their age group (INJUVE 2017) and the results of previous qualitative studies (Castro 2013; Sim et al. 2017). As the data provided by the studies conducted by the Spanish Youth Institute do not distinguish between different ages, it is difficult to determine if the increase of civic engagement in the third year is due to the teacher education program or another age-related cause.

This article also suggests that preservice teachers with different political ideologies and levels of civic engagement share a set of beliefs about CE that are rarely questioned. This consensus about the meaning of CE consists of four main assumptions.

The first assumption is related to the importance given to developing values in CE. Aligned with other studies (e.g., De la Montaña 2012; Marri et al. 2014; Martin 2010), this study found that the majority of trainee teachers tend to associate CE with moral education. We agree with Westheimer (2016) that the moral discourse and its inherent focus on the individual may have detrimental implications for critical CE such as the depoliticization of social problems. The best example of this depoliticization is the preservice teachers' reluctance to both deal with political affairs in the classroom and promote children's political participation. The focus on generic individual virtues and values overlooks the importance of real-life political experiences in the learning of democracy (Biesta 2007; Knight-Abowitz 2008; Schugurensky 2010). Not surprisingly, the preservice teachers interviewed showed difficulties in giving examples of how to bring values education into teaching practices. This result was also found by Thornberg (2008), who warned that for the teachers interviewed in his study, it seems that "values education happens without the teacher thinking a lot about it" (1795).

Regardless of the preservice teachers' political ideology and engagement, the values education discourses were frequently related to the ideal of convivencia (living together in harmony). As Hernando-Lloréns (2019) explains, this ideal "has permeated educational policy and practices in Spain since the beginning of the democratic period in 1978" (2). What is worrying about the salvationist overtones that surround the discourses related to convivencia (Itçaina 2006) is that these discourses often present this idea as the solution to the "problems" and "conflicts" derived from diversity (Hernando-Lloréns 2019). For the sake of convivencia, conflict and controversy are avoided in the classrooms. Although this discourse is shared by both liberal and conservative preservice teachers, its benign and conflict-avoiding tones seem to correspond to the political trends that the quantitative 
results show as well; that is, a large presence of moderate students with low engagement. Therefore, any correlation between ideology and this assumption cannot be ruled out, not in individual terms but rather in the form of a dominant doxa (Bourdieu 1999).

The second most common denominator from the majority of the interviews was the generalized defence of teaching of the cultural and historical heritage of the region in CE. This advocacy made the participants overlook the increasingly multicultural realities of the region and even subordinate the goals of $\mathrm{CE}$ to the construction of territorial identities. As Martín (2001) explains, invocations to tolerance, solidarity, and peaceful coexistence permeate the intentions and objectives, but it is the logic of the territorial identity that permeates the decisions likely to determine the teaching practice (180). The idealized admiration for the culture and traditions of the region was held by both liberal and conservative preservice teachers. In this regard, it would have been interesting to have collected data about the nationalist feelings and preferences of the participants. In any case, their responses indicate a tolerant attitude toward cultural diversity, as other studies with Spanish teachers have pointed out (Cardona et al. 2010; Chiner et al. 2015; Wassell et al. 2018). Yet, they seem to hold what Smith (2009, p. 47) describes as a "tourist" view of cultures, as they do not go beyond the folkloric surface.

The third assumption refers to the neutrality of political literacy teaching, which implies not including current social and political issues in the classroom. Our findings confirm other studies' results conducted with teachers (Byford et al. 2009; Oulton et al. 2004) and preservice teachers (Misco and Patterson 2007) that indicate that both groups usually refuse to teach about current public affairs in order to preserve concord and neutrality, despite the importance of getting children involved in current political debates (Andersson 2016; McAvoy and Hess 2013). Beyond political ideologies and levels of civic engagement, school knowledge is deemed objective and neutral and, therefore, not political.

Finally, the fourth assumption refers to the view of children as not-yet citizens and unable to think critically and participate. For most preservice teachers interviewed, children should be freed from the uncertainty and anxiety that the complexity of political issues and participation generates. Beneath their responses, we observed what Wyness (2006, p. 120) described as an opposition between the innocent child world and the fully sophisticated adult world. This view of children as "not-yet citizens" can be observed through the little attention given to youth involvement in real political affairs. As other studies have previously highlighted (e.g., García and De Alba 2012; Ortega-Sánchez and Pagès 2020; Reichert and Torney-Purta 2019; Roberts et al. 2019), (preservice) teachers usually perceive the promotion of citizen participation as something very disconnected from their teaching goals.

\section{Implications for Teacher Education and Further Research}

The findings of this study suggest that the weight of political socialization in the formation of CE beliefs and dispositions toward including political issues in the classroom is less than what has often been considered by educational research. CE practical knowledge seems to be deeply influenced by other pedagogical conventions such as the neutrality of the teacher or the naturalized conception of school knowledge. This finding is particularly important for two reasons.

Firstly, the above result provides additional evidence to rethink the relationship between political ideology and educational beliefs, as this relationship might not be operating in the conventional linear sense. Educational beliefs might also be shaping political ideologies and behaviors. Unfortunately, we are still far from speculating why high political engagement was seven percentage points higher in the primary education teaching program than in the early childhood education. Further research is needed in this regard.

Secondly, this finding directly challenges teacher educators, as those pedagogical conventions are intimately related to our field of work: school socialization processes. In other words, the scope of teacher education increases if the critical review of the conventions acquired during school socialization processes play a greater role in the formation of 
preservice teachers' understandings of CE. To date, however, several studies have pointed out that teachers do not receive enough training to teach CE (Akar 2012; Barr et al. 2015; Castellví et al. 2020; Chin and Barber 2010; Oulton et al. 2004; Thornberg 2008). In our previous work conducted with the teacher educators of the participants of this study (Estelles and Romero 2019), we identified several difficulties in bringing the purposes of CE into teaching practices and dismantling the entrenched assumptions that preservice teachers hold about the curriculum. Therefore, much work remains to be done in teacher education for CE.

In summary, this study suggests that teacher education and research should more seriously consider other variables, different from political views and behaviors, that might be affecting teachers' resistances regarding $\mathrm{CE}$ and the curricular inclusion of social and political issues.

\section{Conclusions}

The study of preservice teachers' political ideology and levels of civic engagement has shown a large presence of moderate students with low engagement that reveals a need to repolitize teacher education programs. This repolitization, however, cannot only consist of promoting preservice teachers' social and political participation. As this study has also found, there are several understandings of CE that go beyond political ideologies and levels of civic engagement. These shared understandings critically affect preservice teachers' attitudes toward including social and political issues in the classroom. Teacher education courses aimed at fostering critical interpretations of CE should help preservice teachers dismantle these common beliefs that might be part of what Bourdieu (1999) calls the doxa of the field.

Author Contributions: Conceptualization, M.E. and J.R.; methodology, M.E. and F.J.A.; software, F.J.A.; formal analysis, M.E. and F.J.A.; data curation, M.E. and F.J.A.; writing-original draft preparation, M.E. and F.J.A.; writing - review and editing, M.E.; supervision, J.R.; project administration, J.R.; funding acquisition, J.R. All authors have read and agreed to the published version of the manuscript.

Funding: This research was funded by the Vice-rectorate for Research and Knowledge Transfer of the University of Cantabria (No. 11.VU03.64662).

Institutional Review Board Statement: This study has the ethical approval of the Ethics Commitee of the University of Cantabria [Project No. 07/2017].

Informed Consent Statement: Informed consent was obtained from all subjects involved in the study.

Acknowledgments: We would like to sincerely thank L. D. Faulkner for his professional English proofreading and editing.

Conflicts of Interest: The authors declare no conflict of interest.

\section{Notes}

1 We have kept the word convivencia in Spanish because, as Hernando-Lloréns (2019) explains, “English translations of it as 'conviviality' or 'coexistence' do not quite capture the capacious nuances of the word" (p. 15).

\section{References}

Akar, Bassel. 2012. Teaching for citizenship in Lebanon: Teachers talk about the civics classroom. Teaching and Teacher Education 28: 470-80. [CrossRef]

Alviar-Martin, Theresa, Jennifer D. Randall, Ellen L. Usher, and George Engelhard Jr. 2008. Teaching civic topics in four societies: Examining national context and teacher confidence. The Journal of Educational Research 101: 177-88. [CrossRef]

Andersson, Erik. 2016. Producing and Consuming the Controversial: A Social Media Perspective on Political Conversations in the Social Science Classroom. Journal of Social Science Education 15: 6-16.

Apple, Michael W. 2008. Is deliberative democracy enough in teacher education? In Handbook of Research on Teacher Education: Enduring Questions in Changing Context. Edited by Marilyn Cochran-Smith, Sharon Feiman-Nemser, Donald J. McIntyre and Kelly E. Demers. New York: Routledge and The Association of Teacher Educators, pp. 105-10. 
Barr, Dennis J., Beth Boulay, Robert L. Selman, Rachel McCormick, Ethan Lowenstein, Beth Gamse, Melinda Fine, and M. Brielle Leonard. 2015. A randomized controlled trial of professional development for inter- disciplinary civic education: Impacts on humanities teachers and their students. Teacher College Record 17: 1-52.

Bickmore, Kathy. 2014. Citizenship education in Canada: 'Democratic' engagement with differences, conflicts and equity issues? Citizenship Teaching $\mathcal{E}$ Learning 9: 257-78.

Biesta, Gert. 2007. Education and the democratic person: Towards a political conception of democratic education. Teachers College Record 109: 740-69.

Bogdan, Robert, and Sari Biklen. 2007. Qualitative Research in Education. Boston: Allyn and Bacon.

Bougher, Lori D. 2014. Cognitive coherence in politics: Unifying metaphor and narrative in civic cognition. In Warring with Words: Narrative and Metaphor in Politics. Edited by Michael Hanne, William D. Crano and Jeffrey Scott Mio. New York: Psychology Press, pp. 250-71.

Bourdieu, Pierre. 1999. Meditaciones Pascalianas. Madrid: Anagrama.

Bourdieu, Pierre. 2007. El sentido Práctico. Buenos Aires: Siglo XXI.

Brownlee, Joanne Lunn, Laura Scholes, Susan Walker, and Eva Johansson. 2016. Critical values education in the early years: Alignment of teachers' personal epistemologies and practices for active citizenship. Teaching and Teacher Education 59: 261-73. [CrossRef]

Bullough, Robert V. 2000. Convertirse en profesor: La persona y la localización social de la formación del profesorado. In La enseñanza y los Profesores, Vol. I. La PROFESIÓN de Enseñar. Edited by Bruce J. Biddle, Thomas L. Good and Ivor F. Goodson. Barcelona: Paidós, pp. 99-165.

Byford, Jeff, Sean Lennon, and William B. Russell. 2009. Teaching controversial issues in the social studies: A research study of high school teachers. The Clearing House: A Journal of Educational Strategies, Issues and Ideas 82: 165-70. [CrossRef]

Cardona, Molto Christina, Lori Florian, Martyn Rouse, and Laura M. Stough. 2010. Attitudes to diversity: A cross-cultural study of education students in Spain, England and the United States. European Journal of Teacher Education 33: 245-64. [CrossRef]

Carr, Paul. 2006. Democracy in the classroom. Academic Exchange Quarterly 10: 7-12.

Carr, Paul. 2008. Educating for democracy: With or without social justice. Teacher Education Quarterly 35: 117-36.

Carr, Paul R. 2011. Does Your Vote Count? Critical Pedagogy and Democracy. New York: Peter Lang Inc.

Castellví, Jordi, Mario Consuelo Díez-Bedmar, and Antoni Santisteban. 2020. Pre-Service Teachers' Critical Digital Literacy Skills and Attitudes to Address Social Problems. Social Sciences 9: 134. [CrossRef]

Castro, Antonio J. 2013. What Makes a Citizen? Critical and Multicultural Citizenship and Pre-service Teachers' Understanding of Citizenship Skills. Theory \& Research in Social Education 41: 219-46.

Chin, Kevin, and Carolyn E. Barber. 2010. A multi-dimensional exploration of teachers' beliefs about civic education in Australia, England, and the United States. Theory E Research in Social Education 38: 395-427. [CrossRef]

Chiner, Esther, Maria Christina Cardona, and Jose Marcos Gomez Puerta. 2015. Teachers' beliefs about diversity: An analysis from a personal and professional perspective. Journal of New Approaches in Educational Research 4: 18. [CrossRef]

Cuesta, Raimundo. 1997. Sociogénesis de una Disciplina Escolar: La Historia. Barcelona: Pomares-Corredor.

Curry, Leslie, and Marcela Nunez-Smith. 2015. Mixed Methods in Health Sciences Research: A Practical Primer. Los Angeles: Sage Publications.

Davies, Ian, Ian Gregory, and Shirley C. Riley. 1999. Good Citizenship and Educational Provision. London: Falmer Press.

De la Montaña, Juan Luis. 2012. Formación inicial del profesorado, ciudadanía participativa e historia. In Educar Para la Participación Ciudadana en la Enseñanza de Ciencias Sociales (vol. 2). Edited by Nicolas De Alba, Francisco F. García and Antoni Santisteban. Sevilla: Díada, pp. 355-62.

Estelles, Maria, and Jesus Romero. 2019. Tacit assumptions of citizenship education: A case study in Spanish initial teacher education. Education, Citizenship and Social Justice 14: 131-48. [CrossRef]

Estelles, Maria, and Jesus Romero. Forthcoming. The Paradoxes of Citizenship Education: Frames and Factors Influencing Dispositions toward Discussing Political Issues in the Classroom. Journal of Social Studies Education Research.

Eurydice. 2005. Citizenship Education at School in Europe. Brussels: European Unit of Eurydice.

Eurydice. 2012. Citizenship Education in Europe. Brussels: European Unit of Eurydice.

Eurydice. 2017. Citizenship Education at School in Europe-2017 Eurydice Report. Luxemburgo: Publications Office of the European Union.

Evans, Mark. 2006. Educating for Citizenship: What Teachers Say and What Teachers Do. Canadian Journal of Education 29: 410-35. [CrossRef]

Fischman, Gustavo E., and Eric Haas. 2012. Beyond Idealized Citizenship Education Embodied Cognition, Metaphors, and Democracy. Review of Research in Education 36: 169-96. [CrossRef]

Fry, Sara W., and Jason O'Brien. 2015. Cultivating a justice orientation toward citizenship in preservice elementary teachers. Theory $\mathcal{E}$ Research in Social Education 43: 405-34.

Gainous, Jason, and Allison M. Martens. 2016. Civic education: Do liberals do it better? Journal of Political Ideologies 21: 261-79. [CrossRef]

García, Francisco F., and Nicolas De Alba. 2012. La educación para la participación ciudadana entre dos polos: El simulacro escolar y el compromiso social. In Educar Para la Participación Ciudadana en la Enseñanza de las Ciencias Sociales (vol.1). Edited by N. De Alba, F. F. García and A. Santisteban. Sevilla: Díada, pp. 297-306. 
Goodson, Ivor F., Christopher J. Anstead, and J. Marshall Mangan. 1998. Subject Knowledge: Readings for the Study of School Subjects. London: The Falmer Press.

Hart, Roger. 1992. Children's Participation: From Tokenism to Citizenship. Florence: UNICEF.

Hernando-Lloréns, Belen. 2019. Differentiating citizenship, criminalizing diversity: Problematizing convivencia in education in Spain. Curriculum Inquiry 48: 1-19.

Hess, Dianna E., and Paula McAvoy. 2015. The Political Classroom: Evidence and Ethics in Democratic Education. New York: Routledge.

Ho, Li-Ching, Paula McAvoy, Dianna Hess, and Brian Gibbs. 2017. Teaching and Learning about Controversial Issues and Topics in the Social Studies. A Review of the Research. In The Wiley Handbook of Social Studies Research. Edited by Meghan M. Manfra and Cheryl M. Bolick. Chichester: Wiley-Blackwell, pp. 321-35.

INJUVE. 2017. Jóvenes, Participación y Cultura Politica. Informe de Resultados. Madrid: Observatorio de la Juventud en España.

Itçaina, Xabier. 2006. The Roman Catholic Church and the immigration issue the relative secularization of political life in Spain. American Behavioral Scientist 49: 1471-88. [CrossRef]

Ivankova, Nataliya V., John W. Creswell, and Sheldon L. Stick. 2006. Using mixed-methods sequential explanatory design: From theory to practice. Field Methods 18: 3-20. [CrossRef]

Kenyon, Elizabeth A. 2017. Lived experience and the ideologies of preservice social studies teachers. Teaching and Teacher Education 61: 94-103. [CrossRef]

Knight-Abowitz, Kathleen. 2008. On the public and civic purposes of education. Educational Theory 58: 357-76. [CrossRef]

Knowles, Ryan T. 2018. Teaching Who You Are: Connecting Teachers' Civic Education Ideology to Instructional Strategies. Theory $\mathcal{E}$ Research in Social Education 46: 68-109. [CrossRef]

Knowles, Ryan T., and Antonio J. Castro. 2019. The implications of ideology on teachers' beliefs regarding civic education. Teaching and Teacher Education 77: 226-39. [CrossRef]

Lee, Wing On, and Jeffrey T. Fouts. 2005. Education for Social Citizenship: Perceptions of Teachers in the USA, Australia, England, Russia and China (Vol. 1). Hong Kong: University Press.

Lopes, Joanna, Thomas Benton, and Elizabeth Cleaver. 2009. Young people's intended civic and political participation: Does education matter? Journal of Youth Studies 12: 1-20. [CrossRef]

Lortie, Dan. 1975. School-Teacher: A Sociological Study. Chicago: University of Chicago Press.

Marri, Anand R., Sara Michael-Luna, Maria Scott Cormier, and Patrick Keegan. 2014. Urban Pre-service K-6 Teachers' Conceptions of Citizenship and Civic Education: Weighing the Risks and Rewards. The Urban Review 46: 63-85. [CrossRef]

Martín, Antonio. 2001. La desnacionalización como exigencia democrática en una didáctica crítica. In Discursos y prácticas para una didáctica crítica de las Ciencias Sociales. Edited by J. Mainer. Sevilla: Díada, pp. 207-17.

Martin, Leisa A. 2010. A comparative analysis of teacher education students' views about citizenship education. Action in Teacher Education 32: 56-69. [CrossRef]

Maxwell, Joseph. 2013. Qualitative Research Design: An Interactive Approach. Thousand Oaks: Sage.

McAvoy, Paula, and Dianna Hess. 2013. Classroom deliberation in an era of political polarization. Curriculum Inquiry 43: 14-47. [CrossRef]

Misco, Thomas, and Nancy C. Patterson. 2007. A study of pre-service teachers' conceptualizations of academic freedom and controversial issues. Theory E Research in Social Education 35: 520-50.

Mouffe, Chantal. 1999. El retorno de lo Político. Comunidad, Ciudadanía, Pluralismo, Democracia Radical. Barcelona: Paidós.

O'Reilly, Michelle, and Nicola Parker. 2012. 'Unsatisfactory saturation': A critical exploration of the notion of saturated sample sizes in qualitative research. Qualitative Research 13: 190-97. [CrossRef]

Ortega-Sánchez, Delfin, and Joan Pagès. 2020. The End-Purpose of Teaching History and the Curricular Inclusion of Social Problems from the Perspective of Primary Education Trainee Teachers. Social Sciences 9: 9. [CrossRef]

Oulton, Christopher, Vanessa Day, Justin Dillon, and Marcus Grace. 2004. Teachers' attitudes and practices in the context of citizenship education. Oxford Review of Education 30: 489-507. [CrossRef]

Patterson, Nancy, Frans Doppen, and Thomas Misco. 2012. Beyond personally responsible: A study of teacher conceptualizations of citizenship education. Education, Citizenship and Social Justice 7: 191-206. [CrossRef]

Prosser, Jon. 2007. Visual methods and the visual culture of schools. Visual Studies 22: 13-30. [CrossRef]

Ramírez, Francisco O., Davis Suárez, and John W. Meyer. 2007. The worldwide rise of human rights education. In School Knowledge in Comparative and Historical Perspective. Edited by A. Benavot and C. Braslavsky. Dordrecht: Springer, pp. 35-52.

Reichert, Frank, and Judith Torney-Purta. 2019. A cross-national comparison of teachers' beliefs about the aims of civic education in 12 countries: A person-centered analysis. Teaching and Teacher Education 77: 112-25. [CrossRef]

Richard, Veronica M., and Maria K. E. Lahman. 2015. Photo-elicitation: Reflexivity on method, analysis, and graphic portraits. International Journal of Research \& Method in Education 38: 3-22. [CrossRef]

Roberts, Amy, Lydia Nganga, and Joanie James. 2019. Citizenship and Civic Education in Costa Rica, Myanmar, and the United States. Journal of Social Studies Education Research 10: 97-126.

Rogers, John, and Joel Westheimer. 2017. Teaching about economic inequality in a diverse democracy: Politics, ideology, and difference. PS: Political Science \& Politics 50: 1049-55. 
Romero, Jesus, and Maria Estellés. 2019. Governmentality, Curriculum Policies, and Citizenship Education: The Need for Historical Research. In Handbook of Research on Education for Participation Citizenship and Global Prosperity. Edited by J. A. Pineda, N. De Alba and E. Navarro. Hershey: IGI Global Editorial Discovery, pp. 274-301. [CrossRef]

Ross, Wayne E. 2017. Rethinking Social Studies: Critical Pedagogy in Pursuit of Dangerous Citizenship. Charlotte: Information Age Publishing.

Ross, Dorene Doerre, and Elizabeth Yeager. 1999. What does democracy mean to prospective elementary teachers? Journal of Teacher Education 50: 255-66. [CrossRef]

Ruitenberg, Claudia W. 2015. The Practice of Equality: A Critical Understanding of Democratic Citizenship Education. Democracy and Education 23: 1-9.

Sant, Edda. 2013. ¿Qué enseño cuando enseño a participar críticamente a mi alumnado? Coherencias e incoherencias entre las finalidades y las prácticas de tres docentes. Enseñanza de las Ciencias Sociales 12: 63-76.

Schugurensky, Daniel. 2010. Citizenship learning for and through participatory democracy. In Learning Citizenship by Practicing Democracy: International Initiatives and Perspectives. Edited by E. Pinnington and D. Schugurensky. Newcastle upon Tyne: Cambridge Scholarly Press, pp. 1-19.

Schugurensky, Daniel, and John P. Myers. 2003. Learning to Teach Citizenship: A Lifelong Learning Approach. Encounters on Education 4: 145-66. [CrossRef]

Sim, Jasmine B. Y., Shuyi Chua, and Malathy Krishnasamy. 2017. "Riding the citizenship wagon": Citizenship conceptions of social studies teachers in Singapore. Teaching and Teacher Education 63: 92-102. [CrossRef]

Sincer, Isil, Sabine Severiens, and Monique Volman. 2019. Teaching diversity in citizenship education: Context-related teacher understandings and practices. Teaching and Teacher Education 78: 183-92. [CrossRef]

Smith, E. Bradford. 2009. Approaches to Multicultural Education in Preservice Teacher Education: Philosophical Frameworks and Models for Teaching. Multicultural Education 16: 45-50.

$\mathrm{Su}$, Justine Z. X. 1992. Sources of influence in preservice teacher socialization. Journal of Education for Teaching: International Research and Pedagogy 18: 239-58. [CrossRef]

Sunal, Cynthia S., Lynn A. Kelley, and Dennis W. Sunal. 2009. Citizenship education in the elementary classroom: Teacher candidates photograph and describe their perceptions. Journal of Social Studies Research 33: 33-70.

Thornberg, Robert. 2008. The lack of professional knowledge in values education. Teaching and Teacher Education 24: 1791-98. [CrossRef]

Torres, Jurjo. 2011. La Justicia Curricular. El Caballo de Troya de la Cultura Escolar. Madrid: Morata.

Tyack, David, and William Tobin. 1994. The 'grammar' of schooling: Why has it been so hard to change? American Educational Research Journal 31: 453-79. [CrossRef]

Wagner, Wolfgang, Nicky Hayes, and Fatima Flores. 2011. El Discurso de lo Cotidiano y el Sentido Común. La Teoría de Las Representaciones Sociales. Barcelona: Anthropos.

Wassell, Beth, Monica Kerrigan, and Maria F. Hawrylak. 2018. Teacher educators in a changing Spain: Examining beliefs about diversity in teacher preparation. Teaching and Teacher Education 69: 223-33. [CrossRef]

Westheimer, Joel. 2016. The Trouble with Moral Citizens: A Response to "Moral-Character Development for Teacher Education by Daniel Lapsley and Ryan Woodbury. Action in Teacher Education 38: 207-11. [CrossRef]

Westheimer, Joel, and Joseph Kahne. 2004. What kind of citizen? The politics of educating for democracy. American Educational Research Journal 41: 237-69. [CrossRef]

Wyness, Micheal. 2006. Childhood and Society. Hampshire: Palgrave. 



\title{
Article \\ School Inquiry in Secondary Education: The Experience of the Fiesta de la Historia Youth Congress in Seville
}

\author{
Nicolás De-Alba-Fernández *D, Elisa Navarro-Medina and Noelia Pérez-Rodríguez (D) \\ Faculty of Education Sciences, University of Seville, C/Pirotecnia s/n, 41013 Seville, Spain; \\ enavarro5@us.es (E.N.-M.); nperez4@us.es (N.P.-R.) \\ * Correspondence: ndealba@us.es
}

check for

updates

Citation: De-Alba-Fernández,

Nicolás, Elisa Navarro-Medina, and

Noelia Pérez-Rodríguez. 2021. School

Inquiry in Secondary Education: The

Experience of the Fiesta de la Historia Youth Congress in Seville. Social

Sciences 10: 165. https://doi.org/

10.3390/socsci10050165

Academic Editor:

Delfín Ortega-Sánchez

Received: 26 March 2021

Accepted: 4 May 2021

Published: 8 May 2021

Publisher's Note: MDPI stays neutral with regard to jurisdictional claims in published maps and institutional affiliations.

Copyright: (c) 2021 by the authors. Licensee MDPI, Basel, Switzerland. This article is an open access article distributed under the terms and conditions of the Creative Commons Attribution (CC BY) license (https:// creativecommons.org/licenses/by/ $4.0 /)$.

\begin{abstract}
In secondary education, the focus of history teaching must be on the development of global citizenship. The present research was a study contextualized in the Fiesta de la Historia Youth Congress in Seville (Spain). A documentary analysis with a descriptive and interpretive design was made of 63 projects of inquiry that pupils carried out. The main objectives were to assess the incidence of the proposal in terms of participation, and to determine whether the pupils' projects followed a logic of inquiry about socially relevant problems which favors the construction of global citizenship. The results point to a low incidence of schools participating in this initiative. The projects of inquiry analyzed present, for the most part, themes related to the historical and social heritage of the locality. The proposals are approached as problems of a specific discipline and are worked on through a method based on a pseudoscientific research process. The findings indicate the need to continue implementing initiatives based on school inquiry that allow the teaching of history to be articulated around relevant social problems, with the objective being to develop citizenship skills.
\end{abstract}

Keywords: history education; social studies; scholar research; relevant social problems; global citizenship

\section{Introduction}

\subsection{The Teaching of History for the Construction of Global Citizenship}

Educating for global citizenship (DiCicco 2016; Engel et al. 2016) implies that the education system is aware of the need to promote not only conceptual elements but also affective and value-based elements, since the starting premise is that a citizen must feel themself as such if our intention is for them to reach their full development as a social being. This is supported by European organizations and reports, such as Agenda 2030 (Unesco 2017) and the Faro Convention (Council of Europe 2005). It is not enough to know its benefits at a theoretical level. Instead, it is necessary to generate processes that allow pupils to develop values and skills that commit them to a real participation (García 2019). Therefore, the task of schools is to educate children and adolescents in the exercise of their rights and duties, in the principles of liberty and respect, and in the promotion of democracy as a mechanism for their political and social development (Apple 2018). In this way, the creation of more democratic societies and people should be mediated both by the democratization of educational systems and schools (Aguirre and Schugurensky 2017) and by its inclusion in the curricula. When one analyzes the study plans for the subject of history in secondary education ${ }^{1}$ in Spain, and in Andalusia in particular, one can see the link between the teaching of this subject and the development of citizenship. The teaching of history, together with other disciplines in the area of social sciences such as geography, as part of preparation for citizenship is not only essential to knowing about the past but also to "glimpse some of the problems of the future" (Real Decreto 1105/2014, p. 297). The teaching of both history and geography allows young people to understand "social events, processes, and phenomena in the context in which they occur, to analyse the processes that gave rise to historical changes, and to continue acquiring the skills needed to understand 
the reality of the world in which they live, past and present collective experiences, [and] their orientation in the future" (Real Decreto 1105/2014, p. 297). Having a historical perspective allows pupils to know what their reality is and gives them the capacity to analyze and explain the problems of the society of which they are part (Sobejano and Bravo 2010). The Curricular Order of Andalusia (Orden de 14 de julio de 2016) notes that the study of this core subject favors "the analysis and implementation of the precise strategies to exercise a responsible, participatory citizenship, [that is] aware of its identity, rights, and obligations, in a plural and globalized environment" (p. 156).

This relevance given to the citizenship dimension in the social sciences curriculum is, in turn, supported by education research. Numerous studies have shown that history is a basic vehicle through which to transport our societies' values and changes, relating its educational function, purposes, and propositions to the civics training of young people (Navarro-Medina and de-Alba-Fernández 2011, 2014, 2019). This allows working with the young on their future as citizens, going beyond the mere reproduction of outstanding events and figures from the past, and generating in the pupils a historical and transformative awareness (Pagès 2019). For Santisteban (2010), it fulfils a still greater function-the teaching of history encourages the formation of historical thought, it being necessary to provide pupils "with a series of instruments of analysis, understanding or interpretation" (p. 35) that can lead them to construct their own representation of the past, away from manipulations or biased narratives. A link is established between historical awareness and civic awareness, beginning with the premise that history is fundamental for a democratic education and the construction of identity (Santisteban and Anguera 2014). However, achieving these links entails a certain way of teaching and learning history. Following this line, there have been several authors (Evans and Saxe 1996; Legardez and Simonneaux 2011; Santisteban 2017) who note the necessity to work on history from socially relevant problems that are present in our own and in our pupils' everyday lives, and that are of concern to us, in order to analyze their evolution and construct their future projection. Together with this, the teaching of history from a perspective of working on the basis of current problems will allow us, at the same time, to develop the consciousness of historical time (past-present-future) and historical awareness, completing the usefulness of teaching this subject for the development of education for global citizenship.

\subsection{School Inquiry Processes as a Strategy for the Construction of Global Citizenship among Pupils}

To fulfil the objectives of the teaching of history as an educator for citizenship, it is necessary to generate processes in class that encourage pupils to analyze and understand the relevant social problems that occur around them. In this sense, there is an important current in the areas of social sciences (Paraskeva 2003) which connects this way of working with an entire pedagogical tradition (Rousseau, Pestalozzi, Dewey, Freinet, among others) that puts the focus on the pupils' active role in their learning. Working on socially relevant problems in class involves adopting an inquiry-based method. The fundamental difference between this and other active methods is that while the latter are only concerned with the learning of skills and procedures-and with replicating in class the researcher's work-the former deals with the contents of the disciplines (not just conceptual but also procedural, and of attitudes and values), starting from the pupils' everyday conceptions of a series of problems with which to organize the content to be taught and learnt (García and García 1989).

Therefore, including inquiry in the classroom means going beyond the use of specific strategies. Rather, it is a matter of understanding the teaching and learning process in an overall way, characterized, among other issues, by a constructivist vision of learning, recognizing the pupils' ideas as a source from which to build knowledge and which is in permanent progression, and by the necessary interaction between the school and the social worlds (García and García 1989).

Thus, in order to start a process of inquiry in the classroom, the first thing that should be considered is a school-appropriate problem. In this regard, and in relation to social sciences, Washburne (1967) stated that current problems should be the basis on which to 
settle the selection of what will be studied, and that the process should be designed to give a response and conclusion to the said problems. For Santisteban (2017, p. 92), "the teaching of history and of the social sciences must begin from relevant social problems that concern us, analysing their historical evolution until a projection towards the future has been constructed", because this will enable us to work in class on historical time (past-present-future) and historical awareness, reflecting the usefulness of the teaching of history in education for global citizenship. Various research findings support this claim. The work of Salinas and Oller (2017) reveals how learners are in agreement with treating controversial issues in class, claiming that this allows them to become informed, take a position, and concern themselves about issues that affect their contexts, as well as giving them the possibility to acquire a greater sensitivity about what is happening around them locally, regionally, and globally. For Muñoz and Pagès (2012), the study of pastpresent relationships, and therefore the fostering of historical and civic awareness, must be carried out on the basis of issues concerned with wars, political questions, economic crises, and people's rights. In this line, Rapoport (2013) analyzed the work that teachers conduct to educate about citizenship through the teaching of social sciences. His results show that the participants do not use a specific method to teach themes related to global citizenship. Nonetheless, two strategies are present in the themes which promote global citizenship education: the comparative approach, and teaching controversial themes. Here, it is necessary to make a terminological comment. The present study agrees with Legardez (2017) that, for a social problem to be teachable in school, it must present three elements: be current, be relevant to the scientific discipline, and be meaningful in the school context. García et al. (2017), who agree with this, add that it should be significant for both pupils and society. Therefore, those proposals which present the content as a problem corresponding to the curriculum or solely a discipline-specific one, without taking into account the rest of its outstanding elements, cannot be considered relevant social problems.

Together with putting forward socially relevant problems, the second of the steps within the school inquiry process must be to take note of the pupils' conceptions about the phenomenon. To construct new knowledge, it is necessary to know what the pupils' current everyday knowledge is in their understanding and explanation of the world (García and García 1989). Along these lines, Davis et al. (2001) noted that to develop historical empathy and understand historical processes, it is necessary to take into account what pupils know, understand, and identify with. Llorente and Etxeberria (2019) pointed out that to achieve this, it is necessary to link together three processes: the complex historical contextualization of the event; managing to look at the event from a certain historical perspective; and an affective connection that can be achieved through the pupils' connecting their own experiences with those being studied.

Once the problem to be worked on has been defined and the pupils' ideas taken into account, there begins the phase of the school inquiry process. This will provide a great diversity of information or content for the pupils' initial ideas regarding the problem to be restructured and made more complex. Here, the various referents for accessing knowledge (the pupils' ideas, the sociocultural reality in which they find themselves, the teacher as a source for providing information, textbooks, documents, materials, etc.) come into play. The essence of this phase is the planning of a considerable number of activities of contrasting. These activities are understood to be experiences for the pupils to construct knowledge based on confronting their own ideas with information obtained through the different activities proposed. In the case of history, this phase of working with new information allows global citizenship competencies to develop since it favors the "implementation of learning experiences that promote critical thinking and an open and deep discussion about controversial issues" (Aguilar-Forero et al. 2019, p. 107). These activities of contrast can be of various kinds. For Hess (2009), controversy, debate, and discussion are the most powerful strategies with which to generate an education for an aware citizenship. The research study of Fuentes-Moreno et al. (2020) corroborates these ideas. Based on the design and implementation of five didactic units with the common denominator of 
working on social problems for the development of civic competence, those authors used teaching methods based on a challenge or question, analysis of sources, and applying the hypothetical-deductive method. Their results show that the pupils participating in the study developed active citizenship attitudes and skills. In this line, Santisteban and Anguera (2014) argue that it is necessary to propose activities that allow pupils to develop four competencies of historical thinking from the citizenship perspective: "(a) those related to historical imagination (empathy, contextualization and moral judgement); (b) narrative as an essential form of historical discourse, which can evolve as a causal or intentional historical explanation; (c) the interpretation of primary and secondary historical sources, and the solution of historical questions-problems; (d) historical-temporal awareness, as an understanding of the changes and continuities in History" (p. 251).

The last phase of a school inquiry process is drawing conclusions. This last step allows the pupils to make explicit the results of the learning process, and of the restructuring of their initial ideas in relation to the problem posed, and it represents a natural culmination of the school inquiry. Here, together in common with their peers, they present the results of their work. Giving them the possibility of putting their learning into practice allows them, on the one hand, to fix the content they have learnt, and, on the other, to gain confidence in their own abilities (García and García 1989). Interesting in this sense is the work of Morgade (2017) in which she studied her pupils' change in conceptions through the elaboration of a didactic proposal that worked on a socially relevant problem (in this case, the Spanish Civil War and historical memory in Pontevedra). This shows that this type of classroom experience allows pupils to develop competencies linked not only to the knowledge of historical events but also, above all, to the ability to analyze, interpret, and assess current events in the light of the past, to project a future, and to construct a participatory citizenship that is critical of the world in which they live. A diagram of these school inquiry phases is presented in Figure 1.

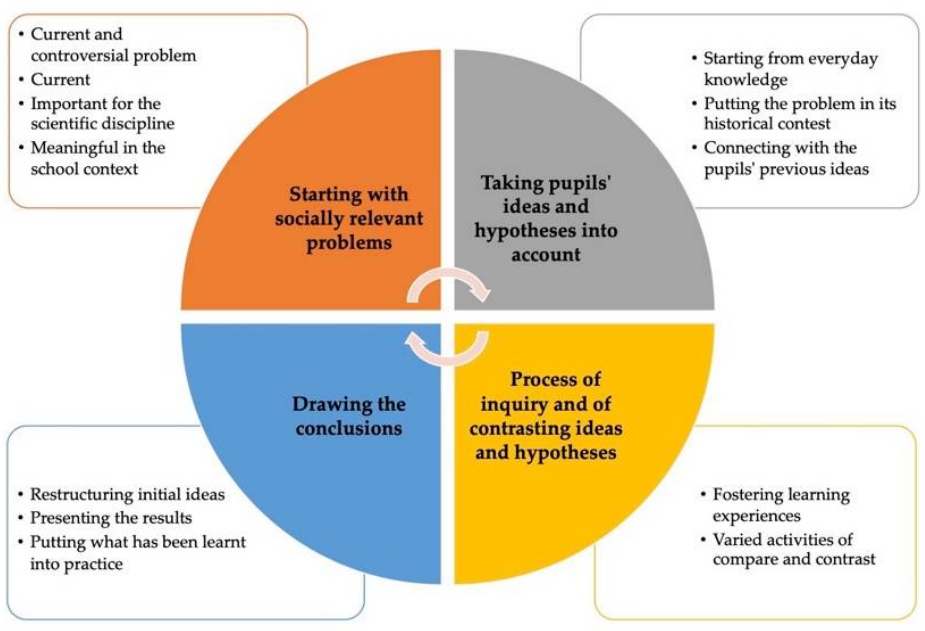

Figure 1. Phases and characteristics of the process of school inquiry.

Nonetheless, this process of school inquiry often faces obstacles to its development. Two of these, noted by García Gómez (2011), are the instability of teaching, which leads to the teacher having little knowledge about the reality of the school and the pupils, and a lack of commitment to the school's work. Furthermore, this uncertainty in which they move means that the effort the teachers have to make to change their teaching methods will not be seen as receiving sufficient compensation, thus perpetuating a transmissive type of teaching model. The use of textbooks, which is even sometimes imposed in secondary school departments, may appear to be the only resource that provides security and reduces the workload. This use of textbooks encourages the survival of a traditional system that is deeply rooted in both the teachers (with their reproduction of models that they lived with in their own education) and the pupils (clinging to the passive role that, for centuries, has 
been imposed on them in all the stages of the education system). Class routines prevail that are marked by the explanation of the theme and completing and correcting homework (García Pastor and Gómez 2008), where the activities designed respond to a predetermined scheme, and neither question the pupils' ideas nor link to complex cognitive processes. In addition, individual learning is encouraged, translated into the organization of the classroom space (individual seating) and the type of tasks requested (generally to be solved alone, without small or large group work). Last but not least, working from a school inquiry model is associated with the negative connotation that the contents are not worked on, clearly reflecting the obsession with needing to teach the entire syllabus (García and García 1989; García Gómez 2011).

These obstacles to school inquiry are accompanied by others specific to implementing citizenship education through the teaching of history. Tutiaux-Guillon (2003) pointed out that the problem is that teaching practices do not favor the development of pupils' democratic attitudes. Boadu (2020) showed that the practices in the classroom of the 24 history teachers he studied reveal minimal attention to the problematization of historical knowledge, since most of the participants teach history as great narratives. This leads to some of the conclusions of Lucas and Delgado-Algarra (2018), who state that promoting civic attitudes among pupils is directly linked to the teacher's clear commitment towards social problems. It also highlights the idea of Delgado-Algarra and Estepa-Giménez (2017) that history teachers still have "a traditional conception of teaching with limited participatory nuances" (p. 273).

\subsection{The Fiesta de la Historia and the Fiesta de la Historia Youth Congress}

The Fiesta de la Historia in Seville began in 2015 as an extrapolation of the "Festa Internazionale della Storia" that is held in Bologna (Italy) (Borghi 2012). Conceived of as an activity for the dissemination of history and heritage, it is a week in which historical science is promoted in schools and among citizens through exhibitions, guided visits, and various activities. The ultimate objective is to value the culture and history of the location as common heritage from a common perspective of the development of citizenship.

In this framework, in 2016, an activity denominated "Fiesta de la Historia Youth Congress" was created. It was conceived of as an essential element for the construction of global citizenship in secondary schools through the dynamization of the teaching of history and social sciences in which it is the pupils themselves who, based on their research-type inquiry, give value to the history that surrounds and shapes us as citizens. The intention is for the Congress to function as a facilitator of innovation and change in the teaching of social sciences, advancing from methods based on the almost exclusive use of textbooks and memorization towards inquiry-based methods. For the schools, this event acts as a place to show, after several months of classroom work, the result of an inquiry-based way of teaching social sciences. Ultimately, its purpose is to improve both pupils' ability to analyze the reality which surrounds them and their active and civic participation in the affairs of their environment.

The call for projects is published at the beginning of the school year, in September. It is targeted at lower and upper secondary education pupils of the entire province of Sevilla (Spain), although schools in other neighboring provinces also respond to the call. The organizing committee puts out some methodological guidelines to take into account in carrying out the projects. These are as follows: the development of work in small groups that is cooperative in nature; that the pupils carry out the inquiry autonomously (with monitoring and advice from their teaching staff); and consultation of different types of sources-oral testimony, active searches on the Internet, work in libraries and other sources of documentary heritage, visits to places of interest, etc. During the course, the pupils develop projects of inquiry that are preferably related to aspects or problems which allow what is investigated to have an impact on citizens, with especial attention paid to civic participation. Some of the suggested themes are: diverse aspects of local history; the life of historical figures; the life of our ancestors; the historical, cultural, natural, and scientific 
heritage of the locality or environment; the genesis of the city or town in which one lives; life in the neighborhood; the struggle to improve the well-being of citizens; milestones in contributions to the improvement of society (the printing press, theatres, the creation of the first schools or hospitals, the sewage system, trades and their places, traditions, etc.); the knowledge of other cultures whether or not related to one's own, looking for possible relationships; flamenco; and other issues related to the development of citizenship from history.

The event takes place during the month of March and is held at the Faculty of Educational Sciences of the University of Sevilla. In it, the pupils must present the reports that gather the results of their research processes through oral communication, expository panels, or presentations through slides and/or a video with a duration of between seven and ten minutes.

\section{Research Methods}

\subsection{Research Objectives and Questions}

The two main objectives of the present study were:

To evaluate the incidence in terms of participation in the Fiesta de la Historia Youth Congress in the province of Sevilla from 2016 to 2019;

To determine whether the projects developed follow a logic of inquiry into socially relevant problems which favors the construction of global citizenship.

To meet these objectives, the following research questions were set:

Q1.1. What volume of participation over four years does an event focused on pupil inquiry have?

Q2.1. What themes were addressed in the experiences?

Q2.2. Are the themes presented as socially relevant problems or differently?

Q2.3. What characteristics does the method followed in the classroom have?

Q2.4. What is the relationship between the theme and the way it is presented?

Q2.5.What is the relationship between the way the theme is presented and the method followed in the classroom?

\subsection{Research Design, Sample, and Techniques of Data Analysis}

The research carried out was qualitative, descriptive, and interpretive (Creswell 2014). To achieve Objective 1, a longitudinal study from 2016 to 2019 was proposed in order to determine the volume of both state and private secondary school participation in the Youth Congress, mostly from the province of Sevilla, with a minor participation from other provinces of Andalusia such as Huelva, Cádiz, Córdoba, and Almería (linked to Q1.1). Sampling was intentional, with all centers participating from the beginning of the event (Creswell 2014).

To achieve Objective 2, a documentary study was carried out based on the data provided by the participating schools, and 63 reports presented by the participating pupil groups were analyzed. Each report consists of the following elements: 1 . title of the project; 2. problem or topic investigated; 3 . brief summary; 4 . description of the research process followed in the classroom; 5 . results and conclusions obtained from the research; 6 . dissemination of the entire process at the event.

With the qualitative analysis, information was extracted from the dataset, without establishing previous categories or patterns, by following the guidelines of grounded theory (Strauss and Corbin 2002). In the first phase consisting of open coding, the categories directly linked to the research problems were identified. Three families of codes emerged from this analysis: themes used in the experiences, the way the themes are presented, and a hypothesis of progression of the method followed in the classroom (linked to Q2.1, Q2.2, and Q2.3, respectively). In the second phase consisting of axial coding, the three families of codes were categorized according to their relationships with each other. To this end, the Justifies function of Atlas.ti was applied to the citations of the categories identified, which made it possible to create co-occurrence tables (Friese 2012). These tables 
facilitate the analysis of the relationships between the categories in terms of the frequencies of simultaneous appearance in the same citation (linked to Q2.4 and Q2.5). In the final phase consisting of selective coding, a network of categories and codes was created that captures the most relevant results of the study. The qualitative results of the three phases were also subjected to frequency analyses in order to obtain a quantitative overview of the study. The software used for the analyses was Atlas.ti v.8.4.4.

\section{Results}

In response to the question relating to the volume of participation in the event (Q1.1), the analysis clearly showed the sparse incidence that the call for participation in the Fiesta de la Historia Youth Congress had on the target schools. As can be seen in Table 1, in the four years analyzed, the representativeness of the schools (both state and private) in Sevilla province barely exceeded 5\%, which denotes that this type of initiative had little impact on the daily life of the secondary school classrooms. Likewise, the presence of other provinces was just anecdotal. Nevertheless, the growth in participation over the years studied does stand out. In the first edition, only six schools participated, while this doubled in the second, to stabilize afterwards.

Table 1. School participation by year ${ }^{1}$.

\begin{tabular}{ccccc}
\hline $\begin{array}{c}\text { Participating } \\
\text { Schools }\end{array}$ & $\begin{array}{c}\text { I Edition } \\
\mathbf{2 0 1 6}\end{array}$ & $\begin{array}{c}\text { II Edition } \\
\mathbf{2 0 1 7}\end{array}$ & $\begin{array}{c}\text { III Edition } \\
\mathbf{2 0 1 8}\end{array}$ & $\begin{array}{c}\text { IV Edition } \\
\mathbf{2 0 1 9}\end{array}$ \\
\hline Province of Sevilla & $6(3.3 \%)$ & $7(3.8 \%)$ & $10(5.5 \%)$ & $9(5 \%)$ \\
Other Andalusian & & 3 Córdoba & 2 Cádiz & 2 Cádiz \\
provinces & & 1 Huelva & 1 Almería & 1 Almería \\
Totals & 6 & 1 Cádiz & 1 Córdoba \\
& & 12 & 13 & 13
\end{tabular}

${ }^{1}$ The percentage representation of schools is relative to the total of public and private schools in the province of Sevilla $(n=181)$. Data retrieved from the website of Ministry of Education and Sports of the Junta (Regional Government) de Andalusia on 15 April 2020: https:/ /www.juntadeandalucia.es/educacion/vscripts/centros/ Escolarizacion2019/index.asp.

Similarly, with regard to the number of reports presented, the data reflect an increase as the editions progressed (Table 2). Thus, in the first edition, only 10 inquiries were presented, while in the second, this number had almost doubled (to 19). In the third and fourth editions, there were fewer, with 16 and 18, respectively.

Table 2. Participation of the different years of secondary education (courses) in the four editions.

\begin{tabular}{cccccc}
\hline Course & $\begin{array}{c}\text { I Edition } \\
\mathbf{2 0 1 6}\end{array}$ & $\begin{array}{c}\text { II Edition } \\
\mathbf{2 0 1 7}\end{array}$ & $\begin{array}{c}\text { III Edition } \\
\mathbf{2 0 1 8}\end{array}$ & $\begin{array}{c}\text { IV Edition } \\
\mathbf{2 0 1 9}\end{array}$ & $\begin{array}{c}\text { Totals by } \\
\text { Course }\end{array}$ \\
\hline 1st ESO & 0 & 0 & 2 & 1 & 3 \\
2nd ESO & 4 & 2 & 2 & 1 & 9 \\
3rd ESO & 2 & 4 & 3 & 1 & 10 \\
4th ESO & 0 & 5 & 7 & 6 & 18 \\
1st Bach & 2 & 4 & 0 & 4 & 10 \\
2nd Bach & 2 & 4 & 16 & 5 & 13 \\
Totals & 10 & 19 & 18 & 63 \\
\hline
\end{tabular}

$\overline{\mathrm{ESO}}=$ lower secondary education. Bach (baccalaureate) = upper secondary education.

If one looks at the experiences presented by the different years (courses) of secondary schooling, most were carried out in the last year of compulsory lower secondary education (ESO, with 18 inquiries), also notable being the numbers presented for the two years of upper secondary (Bach). These data confirm teachers' resistance to proposing inquiry processes in the first years of secondary education (García Gómez 2011). Nonetheless, the results of a study by Santisteban (2019) indicate that pupils are well able to analyze and interpret sources in these 
first lower secondary education years, and that the fundamental problem lies in the lack of custom and in the traditionalism that prevails in teaching (Sáiz Serrano 2013).

With respect to the themes $(\mathrm{Q} 2.1)$, there were eight different ones used (see Figure 2). Of these, just two represent $69.5 \%$ of the inquiries. They are linked to the locality's social, cultural, and historical heritage (38.5\%) and to major historical moments $(31 \%)$. These data confirm the results of Massip et al. (2020) for whom the fact that such themes as heritage or outstanding historical moments are still predominant is linked to the stagnation of school history as a discipline. This is also supported by the curriculum itself: "the History that is presented is that of the great facts and events, and it is almost totally Eurocentric" (p. 184).
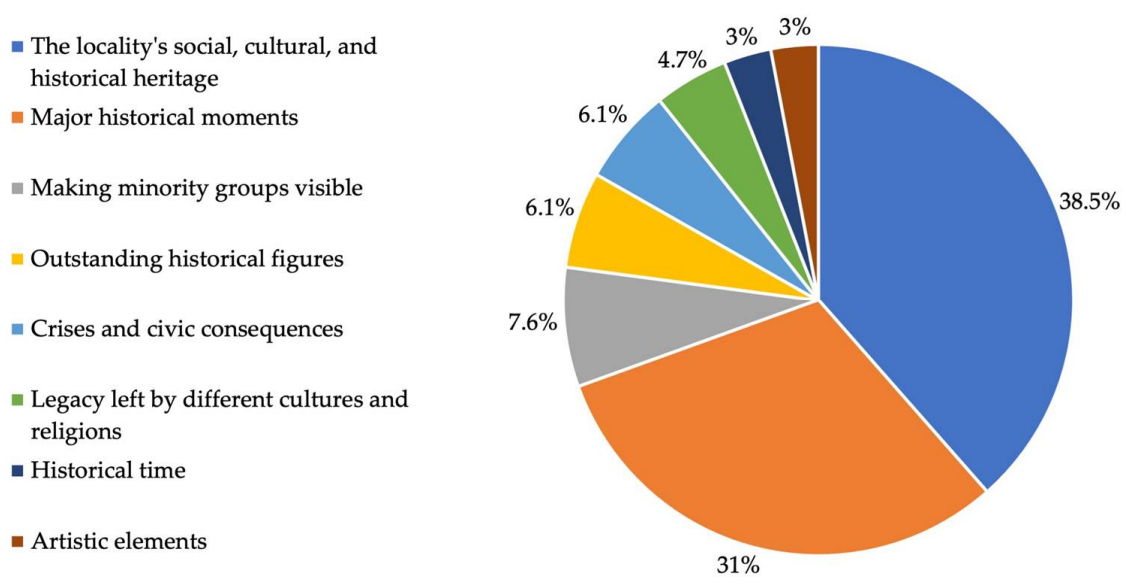

Figure 2. Inquiry themes. Note: two of the cases worked on two themes simultaneously.

The rest of the themes have a notably lesser presence (below 10\%). They go from the visibility of minority groups to the study of artistic elements, passing through outstanding historical figures or the legacy of cultures, among others, as can be seen in the examples listed in Table 3.

Table 3. Examples of allusions to the inquiry themes.

\begin{tabular}{|c|c|}
\hline Inquiry Themes & Examples of Allusion \\
\hline $\begin{array}{c}\text { The locality's social, cultural, and historical } \\
\text { heritage }\end{array}$ & $\begin{array}{l}\text { The “Expo of '92": return to the age of } \\
\text { discoveries } \\
\text { (2018_IIICJFH_1_ESO_SMS_1) }\end{array}$ \\
\hline Major historical moments & $\begin{array}{l}\text { The twilight of the Republic: Seville } 1936 \\
\text { (2016_ICJFH_4_ESO_IES_SE_1) }\end{array}$ \\
\hline Making minority groups visible & $\begin{array}{l}\text { The Seville of Women } \\
\text { (2019_IVCJFH_4_ESO_CBP_1) }\end{array}$ \\
\hline Outstanding historical figures & $\begin{array}{c}\text { Murillo and his time } \\
\text { (2017_IICJFH_1_BACH_IES_M_1) }\end{array}$ \\
\hline Crises and civic consequences & $\begin{array}{l}\text { Economic crises in the contemporary world } \\
\text { and their impact on citizens' lives } \\
\text { (2019_IVCJFH_1_BACH_IES_FM_2) }\end{array}$ \\
\hline Legacy left by different cultures and religions & $\begin{array}{l}\text { Historical roots of gastronomy in the province } \\
\text { of Cádiz } \\
\text { (2019_IVCJFH_4_ESO_IES_CC_1) }\end{array}$ \\
\hline Historical time & $\begin{array}{l}\text { The chronology of the history of humanity and } \\
\text { of our locality } \\
\text { (2018_IIICJFH_1_ESO_IES_P_1) }\end{array}$ \\
\hline Artistic elements & $\begin{array}{l}\text { Historical facts through art } \\
\text { (2017_IICJFH_1_BACH_CBP_1) }\end{array}$ \\
\hline
\end{tabular}


Considering the way the theme is presented (Q2.2), one can distinguish three categories of inquiry for analysis (Table 4): curriculum topics, generally belonging to the content prescribed by the curriculum; topics related to problems typical of the discipline, more appropriate for scientific research in history, geography, anthropology, etc.; and topics that address socially relevant problems, as defined above, linked, in particular, to the school's local context.

Table 4. Examples of allusion to the way in which the themes are presented.

\begin{tabular}{cc}
\hline Form of Presentation & Examples of Allusion \\
Curriculum topic & $\begin{array}{r}\text { The War of Independence (1808-1814): military, social, } \\
\text { political, and religious aspects. } \\
\text { (2017_IICJFH_4_ESO_IES_MS_4) }\end{array}$ \\
Discipline-specific problem & $\begin{array}{c}\text { Evolution of the different atomic models, the study of the } \\
\text { atom, the history of how and why the bomb was created } \\
\text { (different projects), consequences deriving from the bomb, } \\
\text { the incident in Palomares (Almeria) linked to the } \\
\text { environment in which we live, historical framework (Cold } \\
\text { War) and consequences of the use of the first atomic bombs } \\
\text { (Hiroshima and Nagasaki), nuclear fusion and fission. } \\
\text { (2018_IIICJFH_4_ESO_IES_FMA_1) }\end{array}$ \\
Socially relevant problem & $\begin{array}{c}\text { Forgotten, hidden from view, and abused: women without } \\
\text { history, history without women. } \\
\text { (2018_IIICJFH_4_ESO_IES_M_1) }\end{array}$ \\
\hline
\end{tabular}

The data show (Figure 3) that $50 \%$ of the themes were approached as problems of the discipline. This entails overcoming working around a theme that is determined by the curriculum or the reference didactic material (generally textbooks), turning it, instead, into a question approached from a perspective more typical of historical research fields than of classroom inquiry. Nevertheless, this type of classroom work dynamics involves a didactic transposition of just a part of the knowledge that is produced in the historical inquiry (Pagès 2018; Sáiz Serrano and Fuster 2014). Presenting problems from this perspective, even if sources typical of social disciplines are used, does not mean that the pupils are going to develop historical thinking (Sáiz Serrano 2013).

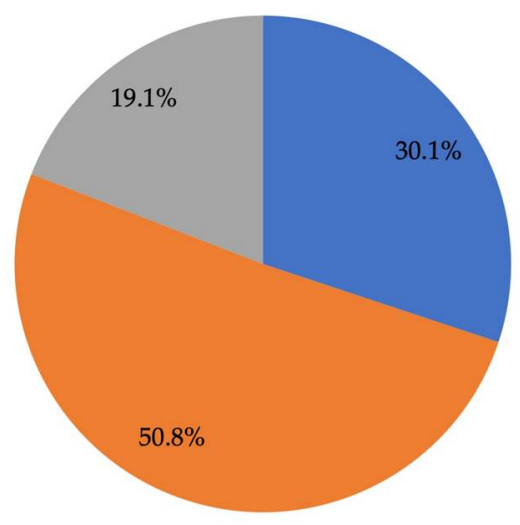

- Curriculum topic $\quad$ Normal problem of the discipline $\quad$ Socially relevant problems

Figure 3. Ways in which the themes are presented. 
Together with this, it stands out in the results that few of the projects (19.1\%) were approached from a perspective of socially relevant problems. This highlights the difficulties secondary education teachers encounter in approaching the curriculum through problems that organize and structure the content (Pineda and García 2011).

Considering the temporal evolution of how the themes are presented (Figure 4), one finds two issues that stand out. The first is that in 2016, none of the 10 inquiries presented were about a socially relevant problem. It is clear, therefore, that the objective set with the event of introducing invigorating and innovative elements into the classrooms did not have the expected reception. This fact was repeated in 2017, when most of the projects presented concerned curriculum themes. The second is that, after these first two years, the working strategy that the event's organization wished to disseminate began to become consolidated, with the inquiry themes corresponding to discipline-specific and even socially relevant problems taking over at the cost of curriculum themes.

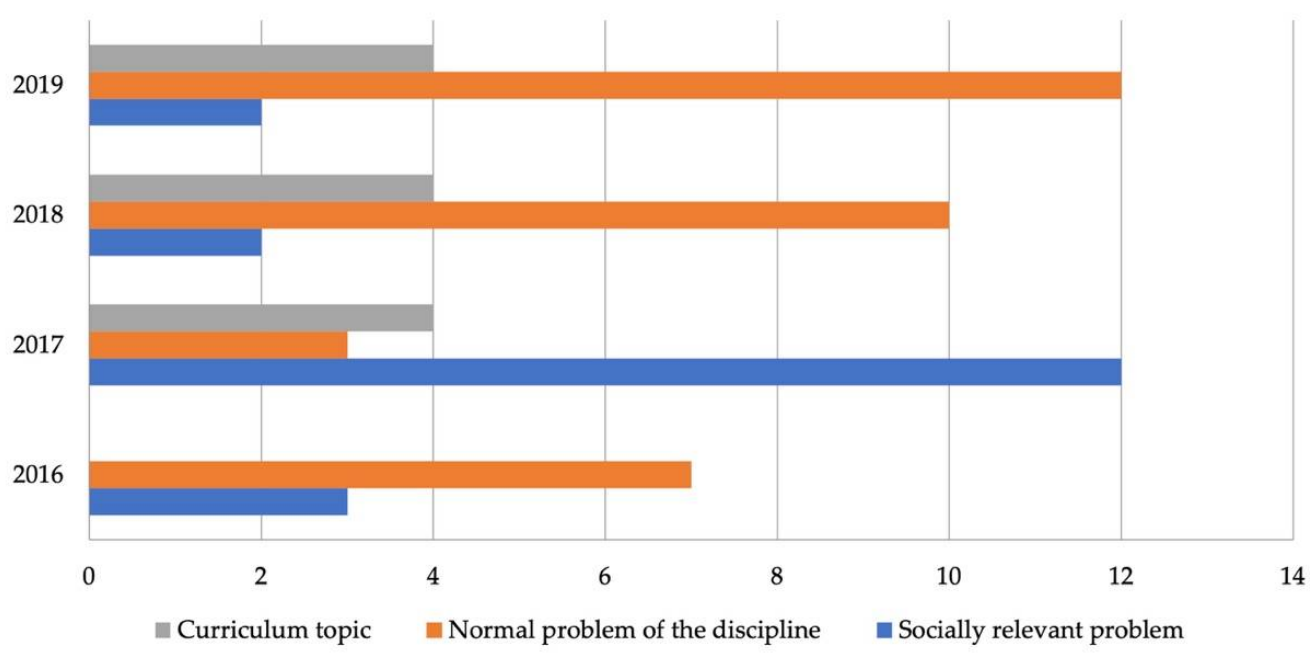

Figure 4. Evolution of the way of presenting content by year of the call.

The characteristics of the methods used emerged from the analysis of the documents (Q2.3). This categorization of the inquiries research allowed us to define the levels of progression that are presented in Table 5 . The first two levels refer to a conception of the classroom method as a directed (Level 1) or autonomous (Level 2) search for information. The higher levels refer to a pseudoscientific inquiry process (Level 3) more typical of discipline-specific research in the historical field, and, finally, a level we consider to be desirable (Level 4), which contains all the phases of a process of school inquiry.

The results (see Figure 5) indicate that $38 \%$ of the cases worked using a pseudoscientific inquiry process. This was followed by autonomous search with $37 \%$. Only $7 \%$ of the cases followed a guided search method. Although it is true that analyzing and obtaining evidence from historical sources and evidence is a basic skill to be able to develop historical and civic thinking, this must "go beyond the simple decoding of textual and iconic information [ ... ] mobilizing capacities that transfer the mere literal understanding" (Sáiz Serrano 2013, p. 45). 
Table 5. Levels of progression of the methods used in the classroom.

\begin{tabular}{|c|c|}
\hline Levels of Methodological Progression & Characteristics or Description of the Process \\
\hline Directed search & $\begin{array}{l}\text { No actual inquiry is carried out, since only one of the phases of the process is } \\
\text { present- the search for information. Additionally, the source is set beforehand. }\end{array}$ \\
\hline Autonomous search & $\begin{array}{l}\text { No actual inquiry is carried out, since only one of the phases of the process is } \\
\text { implemented-the search for information. Nonetheless, the sources are free. } \\
\text { Sometimes, the inquiry process is confused with carrying out activities of content } \\
\text { verification (murals, exhibitions, theatres, etc.). }\end{array}$ \\
\hline Pseudoscientific inquiry & $\begin{array}{l}\text { A pseudoscientific inquiry is carried out in which the process starts from a certain } \\
\text { scientific problem and the pupils perform tasks typical of research in the fields of } \\
\text { history, anthropology, geography, etc. (search for information in archives, } \\
\text { cataloguing pieces, transcription of manuscripts, etc.). Various activities are } \\
\text { carried out as if the pupils were "little historians". }\end{array}$ \\
\hline School inquiry & $\begin{array}{l}\text { A process of school inquiry is carried out which includes all of its phases: a } \\
\text { school-level problem is posed (one that is close to the pupils, important to society, } \\
\text { and relevant from a scientific point of view); the pupils posit their hypotheses and } \\
\text { carry out activities of contrast to confirm or refute those hypotheses; and, finally, } \\
\text { conclusions are drawn concerning the problem that was posed. Sometimes, the } \\
\text { result goes beyond the classroom work itself, and direct transformational } \\
\text { interventions are proposed. }\end{array}$ \\
\hline
\end{tabular}

Table 6 gives some examples that allude to each of these four levels.

Table 6. Examples of allusions to the different levels of methodological progression.

\begin{tabular}{|c|c|}
\hline Levels of Methodological Progression & Examples of Allusions to Each Method \\
\hline Directed search & $\begin{array}{l}\text { "The cholera epidemic of } 1834 \text { in Lebrija" } \\
\text { Problem or theme investigated: The cholera epidemic of } 1834 \text {. } \\
\text { Description of the process followed in the inquiry: } 1 \text {. Select the information from an } \\
\text { article on the subject; } 2 \text {. Prepare a collaborative base document; 3. Prepare a } \\
\text { collaborative presentation; } 4 \text {. Prepare the final product (infographic). In this work, we } \\
\text { study the influence in Lebrija of the first cholera epidemic that appeared in Spain in } \\
\text { 1834, and its effects and consequences in a rural Sevillian town. The study is based on an } \\
\text { article by our teacher which studied the influence of this epidemic in three Sevillian } \\
\text { towns, including Lebrija, for a conference about death and illness in the 19th century } \\
\text { and based on the Chapter Acts and Parish Books of those three towns. } \\
\text { (2019_IVCJFH_2_BACH_IES VC_1) }\end{array}$ \\
\hline
\end{tabular}

"Los Caños de Carmona, Seville's Aqueduct"

Autonomous search

Problem or theme investigated: History and layout of the Aqueduct of Seville. Description of the process followed in the inquiry: Reading of documents and analysis of plans, tables, engravings, and old texts.

(2018_IIICJFH_2_ESO_CBP_3)

"A Cádiz town in the Age of Enlightenment: Chiclana de la Frontera in the mid-18th century"

Problem or theme investigated: The historical past of the locality through the general responses to the Marqués de la Ensenada's Cadastre.

Pseudoscientific inquiry

Description of the process followed in the inquiry: After choosing the object of study, a visit was organized to the town's Municipal Archive. Subsequently, the pupils accessed the digitized documentation in PARES, which they transcribed and analyzed as a group. This was completed with the reading of other secondary (bibliographic) sources, which

helped to shape the data extracted from the primary documentary sources. The pertinent conclusions were drawn in thematic groups, and will be synthesized in digital format in the coming weeks.

(2017_IICJFH_4_ESO_IES PRPC_1) 
Table 6. Cont.

"Human rights, memory and civic construction of peace from the Memorial in honour of the Republican Cordobans murdered in the Nazi extermination camps which is located in the Glorieta de Nuremberg in the Valdeolleros quarter [in Cordoba city]." Problem or theme investigated: Life in this neighbourhood, and the struggle to improve the well-being of its citizens.

Description of the process followed in the inquiry: 0. Linked with the work being carried out in the school within the project "Valdeolleros, our neighbourhood"; 1. Presentation by the teacher of the possibility to research into this theme within the project "Valdeolleros, our neighbourhood" around a memorial in honour of the Republican Cordoba people murdered in the Nazi concentration and extermination camps; 2. Configuration of a work group made up of four pupils from 4th ESO; 3. Generation of a working outline or script based on the initial hypotheses and a work schedule over time; 4 . Determination of the documentary sources to be used: written documentation, oral sources, audiovisual sources, photographs, historical heritage (sculptures and public memorials); 5 . Development of the inquiry project: several visits to the Memorial de la Glorieta de Nuremberg; consultation of historical documentation about Nazism, World War II, the History of Spain in the twentieth century, specifically, in textbooks in the school; conducting a historical workshop on "Cordobans in the Nazi concentration camps", with the presence of the University of Sevilla professor, Don Ángel del Río; carrying out a survey to interview people of the neighbourhood and

School inquiry various other persons who could provide us with information about the said memorial (university professors, schoolteachers, the former Director General of the Democratic Memory of the Junta de Andalucía, people from the neighbourhood, and victims of Francoism or relatives of victims of the Nazi camps); recording, analysis, and study of the interviews carried out; a round-table of all the members of the school's History

Department to debate with the class about the historical period being dealt with; documentation of the contacts and projects between Nuremberg and Cordoba through an interview with Don Juan Gregorio Ramírez, president of the North District Council of Cordoba and a key figure in the relations of the Valdeolleros neighbourhood with the association Conoris de Nuremberg; 6 . Establishment of a proposal to enhance the value of the Memorial for the citizens of Cordoba in the Barrio de Valdeolleros, inserted to be part of the project "Valdeolleros, our neighbourhood"; connection and collaboration with the neighbourhood's collectives; 7 . Drafting a collaboration project of the IES [secondary school] "Grupo Cántico" with the city of Nuremberg to develop activities to construct citizenship, projects in defence of freedom, and human rights through the collaboration of Don Juan Gregorio Ramírez; 8. Explanation of the project to our peers, teachers, and neighbours in various events over the next two terms; 9 . Recording of a video documentary that will reflect all the aspects worked on in the inquiry; 10 . Its dissemination on social networks. (2019_IVCJFH_4_ESO_IES GCC_1)

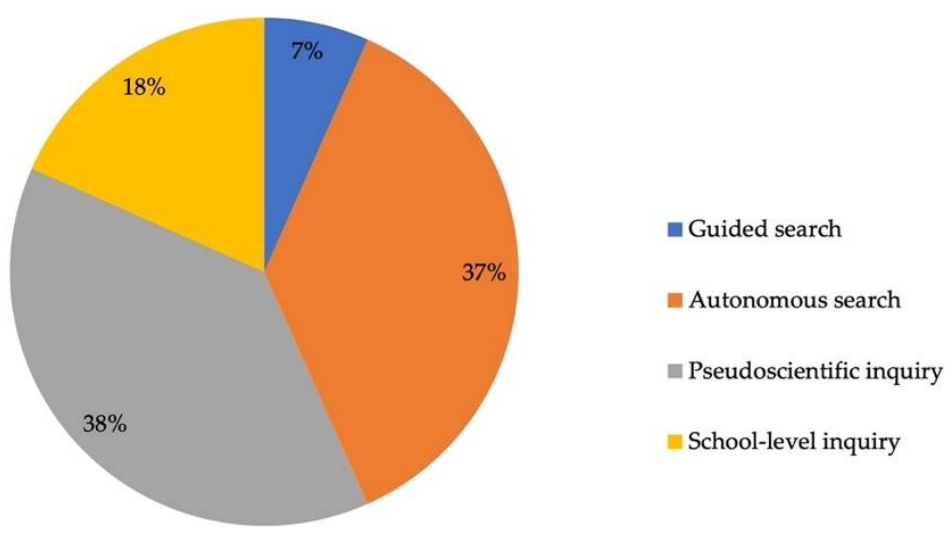

Figure 5. Classification of the methods used in the classroom. Note: In three of the cases, it was impossible to establish the level of inquiry carried out since it was not made explicit. 
However, only $18.3 \%$ of the cases analyzed followed a school inquiry method as described above. This is a reflection of the difficulties and obstacles confronting the implementation of innovative processes in secondary education classrooms (García Gómez 2011).

From a chronological perspective, it is noteworthy that, in the first edition of the Congress, inquiry that followed an autonomous search method prevailed. In the second and third editions, there was a considerable increase in the number of experiences based on a pseudoscientific inquiry method. In the last edition analyzed, however, the data reflect a regression towards the use of methods that are further away from the school inquiry proposals (see Figure 6).

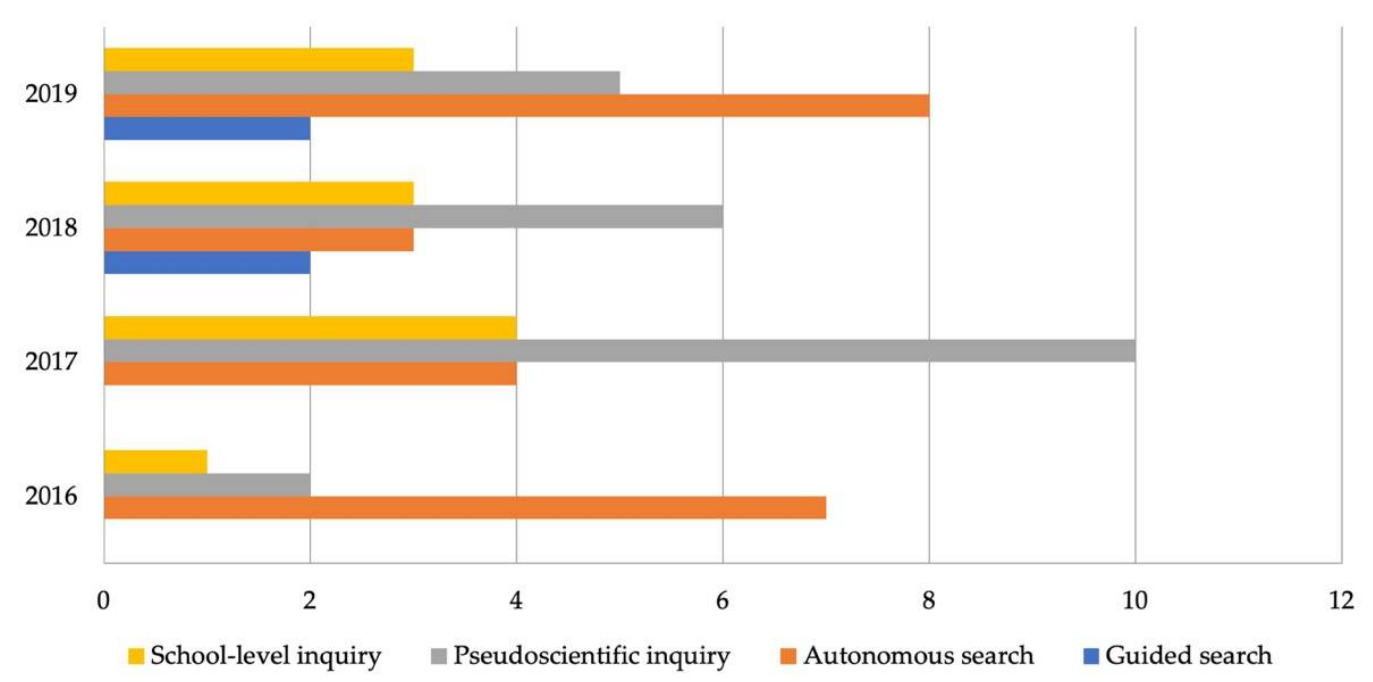

Figure 6. Annual evolution of the classification of the methods used in the classrooms.

With respect to Q2.4, according to the data, there is a positive relationship between the inquiry theme and the way in which it is presented (Table 7). Thus, for those questions that relate to knowing about the locality's social, cultural, and historical heritage, there is a focus on inquiry into a discipline-specific problem as well as, on a considerable number of occasions, on inquiry into a socially relevant problem. On the contrary, the projects that address outstanding historical moments are presented as curriculum themes, generally because these are established and presented in textbooks, and the method proposed only provides an intention to look into them in greater depth.

Table 7. Co-occurrences between inquiry themes and the way the content is presented.

\begin{tabular}{|c|c|c|c|c|}
\hline \multirow[t]{2}{*}{ Themes } & & Curriculum Topic & $\begin{array}{c}\text { Discipline-Specific } \\
\text { Problem }\end{array}$ & $\begin{array}{c}\text { Socially Relevant } \\
\text { Problem }\end{array}$ \\
\hline & & $n=19$ & $n=32$ & $n=12$ \\
\hline $\begin{array}{c}\text { The locality's social, cultural, and } \\
\text { historical heritage }\end{array}$ & $n=25$ & 3 & 14 & 7 \\
\hline Major historical moments & $n=20$ & 10 & 9 & 1 \\
\hline Making minority groups visible & $n=5$ & 1 & 1 & 2 \\
\hline Outstanding figures & $n=4$ & 2 & 1 & 1 \\
\hline Crises and civic consequences & $n=4$ & 0 & 3 & 1 \\
\hline $\begin{array}{l}\text { Legacy left by different cultures } \\
\text { and religions }\end{array}$ & $n=3$ & 1 & 2 & 0 \\
\hline Historical time & $n=2$ & 1 & 1 & 0 \\
\hline Artistic elements & $n=2$ & 1 & 1 & 0 \\
\hline
\end{tabular}


Finally, the relationship established between the way of presenting the theme and the levels of progression of the method used in the classroom (Q2.5), as presented in Table 8, indicates that, as the themes get closer to inquiry into socially relevant problems, the method used becomes more complex and typical of school inquiry. Thus, for inquiries into issues corresponding to the curriculum, a method based on the autonomous search for information predominates (9 experiences); the works presented as problems of the discipline (15 experiences) follow a pseudoscientific inquiry process, with tasks typical of historical research; and, finally, the works addressing socially relevant problems ( 9 experiences) are developed through a school inquiry process.

Table 8. Co-occurrences between the method used in the classroom and the way the content is presented $^{1}$.

\begin{tabular}{ccccc}
\hline $\begin{array}{c}\text { Form of } \\
\text { Presentation }\end{array}$ & Directed Search & $\begin{array}{c}\text { Autonomous } \\
\text { Search }\end{array}$ & $\begin{array}{c}\text { Pseudoscientific } \\
\text { Inquiry }\end{array}$ & School Inquiry \\
\cline { 2 - 5 } & 1 & 9 & 8 & 0 \\
\hline $\begin{array}{c}\text { Curriculum } \\
\text { topic } \\
\text { Discipline- } \\
\text { specific } \\
\text { problem }\end{array}$ & 2 & 11 & 15 & 2 \\
$\begin{array}{c}\text { Socially relevant } \\
\text { problem }\end{array}$ & 1 & 2 & 0 & 9 \\
\hline 1 lost in $2017 ; 2$ lost in 2018. & & &
\end{tabular}

\section{Conclusions}

The present research has allowed us to determine and analyze the repercussion of the Fiesta de la Historia Youth Congress in Sevilla province and of the projects that were presented throughout four editions of it. The results have highlighted the need to continue delving into activities of this type and their dynamics. One of the first results is linked to the low impact of this type of initiative, at least in the schools of Sevilla province. The most plausible explanation for this fact may be the resistance inherent in the culture of schools and teachers to accept external proposals or initiatives (Bolívar 2007; Fullan 2007). Although there are a group of teachers who are interested in proposing other classroom dynamics, their participation is just anecdotal. In addition, the processes of educational change and innovation depend on multiple factors that condition and hinder them (Murillo and Krichesky 2012). Additionally, noteworthy is the fact that, in the course of the four years of the Congress, the presence of the schools barely varied. We therefore understand that there is a need to make initiatives of this type visible in other ways so that they truly reach the schools and classrooms, and to find an active involvement that allows these events to stop being seen as something just testimonial.

Other results are in line with some of those reported by Pagès (2018), and which are directly linked to the socio-genesis of history (Cuesta 1998) as a school subject. Thus, the history that is being taught is a chronological history presented in a linear way. This is demonstrated in our case in the two predominant themes: the locality's social, cultural, and historical heritage (as a legacy in the evolutionary-historical narrative of other past cultures and civilizations), and the major historical moments (most often, those of national, political, and factual history). Together with this, the way in which the themes were presented is especially significant since $50 \%$ of them were approached in the form of normal problems of the discipline which are related more to scientific research issues than to school inquiry. Additionally, in the methods used in the classroom, inquiries that start from a scientific problem predominate in which the pupils carry out tasks typical of historical, anthropological, or geographical research. The interpretation of sources stands out in the principal tasks carried out by the pupils in this type of method, which can be a good starting point for broader and more complete school inquiry methods. 
We would highlight, in this sense, the basic operations involved in interpreting sources as ways of thinking about history, which González-Monfort et al. (2011) summarized into three classes: (i) the reading and treatment of documents or historical evidence; (ii) confronting historical texts with different or opposing interpretations; and (iii) the process of constructing history. Santisteban (2010, p. 49) also pointed out that inquiry using sources "favours the development of the competency of historical interpretation but also the incorporation of historical experience" in the sense of including personal, cultural, and historical elements of the pupils when they are interpreting and understanding sources. Nonetheless, working with sources cannot be carried out in a de-contextualized way about any discipline-specific problem whatsoever but must be put into play "based on historical problems from which the pupils put their historical experience into play, for the development of historical competency" (Santisteban et al. 2010, p. 120). In this way, the contextualization of the historical phenomenon and the pupils' capacity to analyze and reason give meaning to the actions of past history and predispose the pupils to developing historical empathy, to understanding other visions of the event, and to put themselves in the place of others (Meneses et al. 2019). Therefore, the main results of the present study, in which inquiry into problems typical of a discipline approached with a pseudoscientific method predominates, confirm the beginning of a process of teaching history in secondary school classrooms favoring the richness of experiences, and allowing the pupils to acquire historical knowledge progressively (Santisteban et al. 2010). It still does not, however, meet the ultimate goal of developing global citizenship because it does not work on relevant social problems (Santisteban 2019).

Our data have brought to light some challenges that need to be faced in order to ensure that the themes of inquiry in the classroom are presented as real relevant social problems to be resolved by means of a school inquiry method. The results indicate that, of the 63 inquiries in the four years analyzed, only $9(14.3 \%)$ were approached in the way actually indicated in the calls for the Congress. In this sense, it seems evident that there is a need to clearly define the learning objectives of a Congress proposal like the one presented here, and especially to encourage the participating teachers to design and carry out learning experiences with their pupils that will allow them to think about and discuss controversial problems and challenges (Aguilar-Forero et al. 2019). Different studies (Llorente and Etxeberria 2019; Morgade 2017; Salinas and Oller 2017) corroborate the positivity of pupils' responses to this type of proposal. Indeed, the results of Llorente and Etxeberria (2019) showed that pupils are highly motivated when the learning of historical content is linked to current and complex situations which allow them to assimilate the interrelated and multi-causal nature of the processes, since, methodologically, the approaches are active, mainly based on the historical method. In other contexts, this type of initiative has also had a great impact. Meerah and Arsad (2010) reported that in Malaysia, it has been shown that including inquiry projects in social sciences subjects (geography, history, and social skills) is vital to enable the formation of informed, competent citizens with high moral standards.

Finally, we think that the decisive element to understanding the data that have been described and analyzed is the part that the teachers play. Although our research has not delved into this aspect, it is undeniable that part of the results obtained are explained by this variable. There is no room for doubt that the teacher is vital to generating rich and meaningful historical experiences for their pupils by making them aware of the sources and of the diversity of historical perspectives (Meneses et al. 2019). Similarly, for teachers to be able to put into practice those historical experiences which foster citizenship among their pupils, it is vital that they develop these competencies in themselves (Tichnor-Wagner et al. 2016). Fuentes-Moreno et al. (2020) concluded that teachers fulfil a fundamental role in the promotion of citizenship education in their classes through the teaching of social sciences, since their role is fundamental in the choice of both content and work methods, as well as in generating learning environments that favor participatory processes. For the Fiesta de la Historia Youth Congress to meet its objectives, it is necessary for teachers to change their model and, above all, for them to have received preparation both in the 
development of historical and civic awareness from a content point of view, and in the teaching strategies and methods that they will promote. The study by Delgado-Algarra and Estepa-Giménez (2017) points to a minority teacher model that is characterized by its fostering pupil engagement, understanding history classes to be a fundamental space for citizenship education, and that does so by tackling conflictive issues through debate as a form of the construction of thinking. Nevertheless, most of the results of that study reflect a teacher who is sensitive to criticism but without transferring this into the classroom context, and that there are major divergences between thinking and practice which, according to those authors, can influence the construction of a democratic and civic attitude in the pupils.

In summary, events with characteristics similar to those of the Fiesta de la Historia Youth Congress represent an improvement for the construction of global citizenship through history in comparison with the usual classroom practices. Nonetheless, in order for it to reach the maximum levels of development that would be desirable, based on investigation into socially relevant problems through a school inquiry method, it is necessary to provide teachers with training. This is a line that we propose to explore in future work.

Author Contributions: Conceptualization, N.D.-A.-F., E.N.-M. and N.P.-R.; methodology, N.D.-A.-F., E.N.-M. and N.P.-R.; software, N.D.-A.-F., E.N.-M. and N.P.-R.; validation, N.D.-A.-F., E.N.-M. and N.P.-R.; formal analysis, N.D.-A.-F., E.N.-M. and N.P.-R.; investigation, N.D.-A.-F., E.N.-M. and N.P.-R.; resources, N.D.-A.-F., E.N.-M. and N.P.-R.; data curation, N.D.-A.-F., E.N.-M. and N.P.-R.; writing-original draft preparation, N.D.-A.-F., E.N.-M. and N.P.-R.; writing-review and editing, N.D.-A.-F., E.N.-M. and N.P.-R.; visualization, N.D.-A.-F., E.N.-M. and N.P.-R.; supervision, N.D.-A.F., E.N.-M. and N.P.-R.; project administration, N.D.-A.-F., E.N.-M. and N.P.-R. All authors have read and agreed to the published version of the manuscript.

Funding: This research received no external funding.

Institutional Review Board Statement: Not applicable.

Informed Consent Statement: Informed consent was obtained from all subjects involved in the study.

Conflicts of Interest: The authors declare no conflict of interest.

\section{Notes}

1 Secondary education in Spain lasts six years, distributed as follows: the first four years correspond to compulsory (i.e., lower) secondary education (1st, 2 nd, 3rd, 4 th of ESO), and the last two years to the baccalaureate (i.e., upper secondary education-1st and 2nd of BACC).

\section{References}

Aguilar-Forero, Nicolás, Diego Fernando Mendoza Torres, Ana María Velásquez, Daniel Felipe Espitia, Jennifer Ducón Pardey, and Jana De Poorter. 2019. Educación para la Ciudadanía Mundial: Una Innovación Curricular en Ciencias Sociales. Revista Internacional De Educación Para La Justicia Social 8: 89-111. [CrossRef]

Aguirre, Arecia, and Daniel Schugurensky. 2017. La participación como elemento clave en las escuelas democráticas. Revista Reflexão e Ação 25: 46-83. [CrossRef]

Apple, Michael. 2018. ¿Puede la Educación Cambiar la Sociedad? Santiago de Chile: LOM.

Boadu, Gideon. 2020. "Hard" Facts or "Soft" Opinion? History Teachers' Reasoning About Historical Objectivity. Journal of International Social Studies 10: 177-202.

Bolívar, Antonio. 2007. Cómo Mejorar los Centros Educativos. Madrid: Síntesis.

Borghi, Beatrice. 2012. La città, uno spazio per la storia. Esperienze di didattica della storia e del patrimonio a Bologna. Tourisme $\mathcal{E}$ Heritage 1: 61-70.

Council of Europe. 2005. Council of Europe Framework Convention on the Value of Cultural Heritage for Society. Faro: Council of Europe. Creswell, John W. 2014. Research Design: Qualitative, Quantitative, and Mixed Methods Approaches. Thousand Oaks: Sage Publications.

Cuesta, Raimundo. 1998. Clío en las aulas. La Enseñanza de la Historia en España: Entre Reformas, Rutinas e Ilusiones. Madrid: Akal.

Davis, Ozro Luke, Elizabeth Anne Yeager, and Stuart J. Foster, eds. 2001. Historical Empathy and Perspective Taking in the Social Studies. Lanham: Rowman \& Littlefield Publishers.

Delgado-Algarra, Emilio José, and Jesús Estepa-Giménez. 2017. Educación ciudadana y dimensiones de la memoria en la enseñanza de las ciencias sociales: Investigación sobre las concepciones del profesorado de educación secundaria de Huelva y provincia. Educación XX1 20: 259-78. [CrossRef] 
DiCicco, Marzia Cozzolino. 2016. Global citizenship education within a context of accountability and 21st century skills: The case of olympus high school. Education Policy Analysis Archives 24: 1-16. [CrossRef]

Engel, Laura C., Jessica Fundalinski, and Tess Cannon. 2016. Educación para la Ciudadanía Global a nivel local: Un análisis comparado de cuatro distritos urbanos estadounidenses. Revista Española de Educación Comparada 28: 23-51. [CrossRef]

Evans, Ronald W., and David Warren Saxe, eds. 1996. Handbook on Teaching Social Issues. Washington, DC: NCSS.

Friese, Susanne. 2012. Qualitative Data Analysis with ATLAS.ti. Thousand Oaks: Sage Publications.

Fuentes-Moreno, Concepcion, Marta Sabariego-Puig, and Alba Ambros-Pallarés. 2020. Developing social and civic competence in secondary education through the implementation and evaluation of teaching units and educational environments. Humanities and Social Sciences Communications 7: 1-12. [CrossRef]

Fullan, Michael. 2007. The New Meaning of Educational Change. London: Routledge.

García Gómez, M. Soledad. 2011. Viaje a las antípodas de la investigación escolar en la Educación Secundaria. Investigación en la escuela 73: 41-52. [CrossRef]

García Pastor, Carmen, and Soledad García Gómez. 2008. Prácticas de enseñanza y diversidad. Mediodía, Revista del Centro de Profesorado de Osuna-Écija 8. Available online: https://www.researchgate.net/publication/236904669_Practicas_de_ensenanza_y_Diversidad (accessed on 6 May 2021).

García, Eduardo, Rafael Porlán, and Elisa Navarro. 2017. Los fines y los contenidos de enseñanza. In Enseñanza Universitaria. Cómo mejorarla. Edited by Rafael Porlán. Madrid: Morata, pp. 55-72.

García, Francisco. 2019. ¿Es posible educar para la participación ciudadana dentro de la estructura escolar? In Geografia, Educação e Cidadania. Edited by Sergio Claudino, Xosé M. Souto, Raimundo Lenilde, María Á. Rodríguez, Joao Bazzoli, Claudione Lucimar, Luís Mendes and Adilson Basquerote. Lisboa: ZOE, pp. 809-21.

García, José Eduardo, and Francisco Florentino García. 1989. Aprender Investigando. Una Propuesta Metodológica Basada en la Investigación. Sevilla: Díada Editora.

González-Monfort, Neus, Joan Pagès, and Antoni Santisteban. 2011. ¿Cómo evaluar pensamiento histórico? In La Evaluación en el proceso de Enseñanza y Aprendizaje de las Ciencias Sociales. Edited by Pedro Miralles, Sebastián Molina and Antoni Santisteban. Murcia: AUPDCS, pp. 221-31.

Hess, Diana E. 2009. Controversy in the Classroom. The Democratic Power of Discussion. New York: Routledge.

Legardez, Alain, and Laurence Simonneaux. 2011. Education au Développement Durable et Autres Questions Socialement Vives. Dijon: Educagri.

Legardez, Alain. 2017. Propositions pour une modélisation des processus de didactisation sur des Questions Socialement Vives. Sisyphus Journal of Education 5: 79-99. Available online: https:/ / hal-amu.archives-ouvertes.fr/hal-01794120 (accessed on 6 May 2021).

Llorente, Dorleta Apaolaza, and Berta Etxeberria. 2019. Haciendo Historia: Fuentes primarias y metodologías activas para trabajar el pensamiento histórico en Secundaria. ENSAYOS, Revista de la Facultad de Educación de Albacete 34: 29-40. Available online: http:/ / www.revista.uclm.es/index.php/ensayos (accessed on 6 May 2021).

Lucas, Laura, and Emilio José Delgado-Algarra. 2018. Educación para una ciudadanía comprometida en la enseñanza de las Ciencias Sociales: ¿Qué piensa el alumnado de un profesor innovador sobre su aprendizaje? Revista de Didáctica de las Ciencias Experimentales y Sociales 35: 3-16. [CrossRef]

Massip, Mariona, Jordi Castellví, and Joan Pagès. 2020. La historia de las personas: Reflexiones desde la historiografía y de la didáctica de las ciencias sociales durante los últimos 25 años. Panta Rei: Revista Digital de Historia y Didáctica de la 167-96. [CrossRef]

Meerah, T. Subahan Mohd, and Nurazidawati Mohamad Arsad. 2010. Developing research skills at secondary school. Procedia—Social and Behavioral Sciences 9: 512-16. [CrossRef]

Meneses, Belén, Neus González-Monfort, and Antoni Santisteban. 2019. Aprender desde la experiencia histórica. Representaciones del profesorado sobre el uso de la historia oral como estrategia didáctica. El Futuro del Pasado 10: 257-86. [CrossRef]

Morgade, Iria. 2017. "Tras las huellas del maestro": Una propuesta didáctica para el tratamiento de la represión de la memoria en el aula. Revista de Didáctica de las Ciencias Experimentales y Sociales 32: 3-23. [CrossRef]

Muñoz, Enrique, and Joan Pagès. 2012. La relación pasado-presente en la enseñanza de la historia en la educación secundaria obligatoria catalana. Clío \& Asociados 16: 11-38. Available online: http://www.memoria.fahce.unlp.edu.ar/art_revistas/pr.5538/pr.5538.pdf (accessed on 6 May 2021).

Murillo, F. Javier, and Gabriela J. Krichesky. 2012. El proceso del cambio escolar. una guía para impulsar y sostener la mejora de las escuelas. Revista Iberoamericana sobre Calidad. Eficacia y Cambio en Educación 10: 27-43.

Navarro-Medina, Elisa, and Nicolás de-Alba-Fernández. 2011. El aprendizaje de la historia de España para la educación ciudadana. Investigación en la Escuela 75: 21-34. [CrossRef]

Navarro-Medina, Elisa, and Nicolás de-Alba-Fernández. 2014. La formación ciudadana a partir de la enseñanza de la Historia de España: Cuatro situaciones para reflexionar. In La historia de España en los Recuerdos Escolares: Análisis, Interpretación y Poder de cambio en los Testimonios de Profesores y Alumnos. Edited by Nicolás Martínez Valcárcel. Valencia: Nau Llibres, pp. $267-86$.

Navarro-Medina, Elisa, and Nicolás de-Alba-Fernández. 2019. The Construction of Citizenship Model Through the Teaching of History. In Handbook of Research on Education for Participative Citizenship and Global Prosperity. Edited by Jose Antonio Pineda-Alfonso, Nicolás de-Alba-Fernández and Elisa Navarro-Medina. Hershey: IGI Global, pp. 500-16. 
Orden de 14 de julio de. 2016. por la que se Desarrolla el Currículo Correspondiente a la Educación Secundaria Obligatoria en la Comunidad Autónoma de Andalucía, se Regulan Determinados Aspectos de la Atención a la Diversidad y se Establece la Ordenación de la Evaluación del Proceso de Aprendizaje del Alumnado. BOJA, 28 de julio de 2016. Available online: https://www.juntadeandalucia.es/boja/2016/144/BOJA16-144-00289-13500-01_00095875.pdf (accessed on 6 May 2021).

Pagès, Joan. 2018. Aprender a enseñar historia. Las relaciones entre la historia y la historia escolar. Trayectorias Universitarias 4: 53-59.

Pagès, Joan. 2019. Ciudadanía global y enseñanza de las Ciencias Sociales: Retos y posibilidades para el futuro. Revista de Investigación en Didáctica de las Ciencias Sociales REIDICS 5: 5-22. [CrossRef]

Paraskeva, Joao M. 2003. Refutando el reconceptualismo. Michael Apple y su vinculación con una tradición educativa y curricular de carácter progresista y radical. Con-Ciencia Social. Anuario de Didáctica de la Geografía, la Historia y otras Ciencias Sociales 7: 47-82.

Pineda, Jose Antonio, and Francisco Florentino García. 2011. La construcción de un ámbito de investigación escolar sobre el conflicto, la violencia y la guerra. Íber. Didáctica de las Ciencias Sociales, Geografía e Historia 68: 82-91.

Rapoport, Anatoli. 2013. Global Citizenship Themes in the Social Studies Classroom: Teaching Devices and Teachers' Attitudes. The Educational Forum 77: 407-20. [CrossRef]

Real Decreto 1105/2014. de 26 de diciembre, por el que se Establece el Currículo Básico de la Educación Secundaria Obligatoria y del Bachillerato. BOE, 3 de enero de 2015. Available online: https://www.boe.es/boe/dias/2015/01/03/pdfs/BOE-A-2015-37.pdf (accessed on 6 May 2021).

Sáiz Serrano, Jorge, and Carlos Fuster. 2014. Memorizar historia sin aprender pensamiento histórico: Las PAU de Historia de España. Investigación en la Escuela 84: 47-57. [CrossRef]

Sáiz Serrano, Jorge. 2013. Alfabetización histórica y competencias básicas en libros de texto de Historia y en aprendizajes de estudiantes. Didáctica de las Ciencias Experimentales y Sociales 27: 43-66. [CrossRef]

Salinas, Juan José, and Montserrat Oller. 2017. Debatiendo temas controversiales para formar ciudadanos. Una experiencia con alumnos de secundaria. Praxis Educativa 21: 40-48. [CrossRef]

Santisteban, Antoni, and Carles Anguera. 2014. La enseñanza y el pasado-presente-futuro de las sociedades: Formación de la conciencia histórica y educación para el futuro. Clío E Asociados. La Historia Enseñada 18-19: 249-67. [CrossRef]

Santisteban, Antoni, Neus González-Monfort, and Joan Pagès. 2010. Una investigación sobre la formación del pensamiento histórico. In En Metodología de Investigación en Didáctica de las Ciencias Sociales. Edited by Rosa Maria Ávila, Pilar Rivero and Pedro L. Domínguez. Zaragoza: Fernando el Católico/AUPDCS, pp. 115-28.

Santisteban, Antoni. 2010. La Formación en Competencias de Pensamiento Histórico. Clío E Asociados. La Historia Enseñada 1: 34-56. [CrossRef]

Santisteban, Antoni. 2017. Del tiempo histórico a la conciencia histórica: Cambios en la enseñanza y el aprendizaje de la historia en los últimos 25 años. Diálogo Andino 53: 87-99. [CrossRef]

Santisteban, Antoni. 2019. La enseñanza de las Ciencias Sociales a partir de problemas sociales o temas controvertidos: Estado de la cuestión y resultados de una investigación. El Futuro del Pasado 10: 57-79. [CrossRef]

Sobejano, María José Sobejano, and Pablo Antonio Torres Bravo. 2010. Enseñanza de la Historia en Secundaria. Historia Para el Presente y la Educación Ciudadana. Madrid: Tecnos.

Strauss, Anselm, and Juliet Corbin. 2002. Bases de la Investigación Cualitativa. Técnicas y Procedimientos para Desarrollar la Teoría Fundamentada. Colombia: Universidad de Antioquía.

Tichnor-Wagner, Ariel, Hillary Parkhouse, Jocelyn Glazier, and Jessie Montana Cain. 2016. Expanding approaches to teaching for diversity and social justice in K-12 education: Fostering global citizenship across the content areas. Education Policy Analysis Archives 24: 1-35. [CrossRef]

Tutiaux-Guillon, Nicole. 2003. L'Histoire enseignée entre coutume disciplinaire et la formation de la conscience historique. In Identités, Mémoires, Consciente Historique. Edited by Didier Nourrisson and Nicole Tutiaux-Guillon. Saint Etienne: Université de Saint Etienne, pp. 27-44.

Unesco. 2017. Education for Sustainable Development Goals. Learning Objectives. Francia: Unesco.

Washburne, Carleton. 1967. Educación Para una Conciencia Mundial. Buenos Aires: Losada. 


\title{
Article \\ Secondary School Students' Perception of the Acquisition of Social Science Skill
}

\author{
José María Álvarez Martínez-Iglesias ${ }^{1}$ (D), Pedro Miralles Martínez ${ }^{2}$, , Jesús Molina Saorín $^{1}$ (D) \\ and Francisco Javier Trigueros Cano ${ }^{2, *}$ \\ 1 Department of Didactics and School Organization, University of Murcia, 30100 Murcia, Spain; \\ josemaria.alvarez@um.es (J.M.Á.M.-I.); jesusmol@um.es (J.M.S.) \\ 2 Department of Didactics of Mathematics and Social Sciences, University of Murcia, 30100 Murcia, Spain; \\ pedromir@um.es \\ * Correspondence: javiertc@um.es
}

check for

updates

Citation: Martínez-Iglesias, José María Álvarez, Pedro Miralles

Martínez, Jesús Molina Saorín, and

Francisco Javier Trigueros Cano. 2021. Secondary School Students'

Perception of the Acquisition of Social Science Skill. Social Sciences 10: 126

https://doi.org/10.3390/socsci10040126

Academic Editor: Delfín

Ortega-Sánchez

Received: 21 February 2021

Accepted: 26 March 2021

Published: 31 March 2021

Publisher's Note: MDPI stays neutral with regard to jurisdictional claims in published maps and institutional affiliations.

Copyright: (c) 2021 by the authors. Licensee MDPI, Basel, Switzerland. This article is an open access article distributed under the terms and conditions of the Creative Commons Attribution (CC BY) license (https:// creativecommons.org/licenses/by/ $4.0 /)$.

\begin{abstract}
The aim of this study is to find out the relevance of the competences worked on in the area of social science, specifically in the subjects of geography and history, through the perceptions of pupils in the 4th year of compulsory secondary education (ESO). In order to carry out the survey, a purposive sampling was carried out in which more than 1400 4th year ESO students (in Spain) participated. In addition, using a Likert-type scale of our own creation called Evaluation of the Perception of Social Science Competences (EPECOCISO) and following a design of quantitative methodology, an exploratory factor analysis was carried out with the analysis software SPSS through the descriptive process, which allowed us to select the three factors that make up the study. Subsequently, correlations were established between factors through Pearson's test, and between the different variables that make up each one of them with the socio-demographic variables (distinguishing between ordinal and nominal variables) through the chi-square test of independence and Cramer's V test (nominal), as well as the linearity test, Goodman's gamma test, and the Kruskal (ordinal) test. Finally, one of the most important conclusions of this study is that the difficulties encountered by students in the acquisition of competences is conditioned by the development of the assessment processes that are carried out.
\end{abstract}

Keywords: competences; evaluation; social sciences; secondary education; historical thinking

\section{Introduction}

Historically, the school has manifested itself-and has also been perceived as such by society as a whole - as one of the fundamental, most characteristic, and most recognisable elements in the lives of young people, as it has been established as a setting where students are able to create their first affective connections separate from their family nucleus (Bruner 1987). If we take into account everything that has happened in recent decades, we can certainly see the effects that the various educational regulations (national and international) have had, and we can see that, in any case, they have been configured according to a reformist perspective, wishing to overcome an educational system that, despite being reviled, has continued to facilitate an encyclopaedic, traditional, and segregationist teaching (Núñez and Palacios 2004; Monarca and González 2020). From this perspective-and being fully aware that in Spain the curricular model has leaned towards lectures, the transmission of legitimised knowledge, and the repetition of everything learnt by students (Álvarez et al. 2021) — the competency-based teaching-learning model was born, which, passing through all levels of education (basic, secondary, and higher), aims to respond to the demands of society (focused on the diversity of the student body and on getting rid of the illogical belief that all students must learn the same thing at the same time and in the same way). These demands have been expressed in recent decades by European governmental bodies through, for example, the renowned Tuning Educational Structure in Europe project 
developed by the European Union (González and Wagenaar 2003; Rychen and Salganik 2003; Rauner 1999) and the DeSeCo Project driven by the Organisation for Economic Co-operation and Development (OECD) (OECD 2010, 2018, 2019).

But what is meant by "competences"? Clearly, what is being presented is a new way of understanding the educational curriculum, with the desire that-regardless of the territory in which one resides-all learners should achieve common learning focused on their possibilities and demands (Argudín 2005). In this way, the curricular proposals will deal-in a cross-cutting manner-with generic or key competences (in linguistic communication; mathematics; science and technology; digital, social and civic competences; sense of initiative and entrepreneurship; learning to learn; and cultural awareness and expressions). This means, in other words, those competences that are common to all the subjects taught, and which, moreover, should be the central focus of the methodologies proposed by teachers, as well as a set of specific competences that teachers will have to work on more specifically in the subjects they teach, being selected on the basis of these key competences. From this approach, what emerges is the imperative need for education to pursue this comprehensive and permanent (lifelong) approach. In other words, teaching by competences is based on the desire to do away with all disciplinary objectives (based solely on the student's abilities), as well as to provide a vision in which teachers construct a new professional practice with which to facilitate learning that is close to the realities experienced by students-new methodologies that not only address the learning of these operational objectives (known until now for the faithful repetition of knowledge from the teacher to the student and vice versa), but also approach the contexts of the students (their family relationships, their socio-economic level, etc.), and thus approach the students' realities and the realities of their lives, getting closer to what should never have been separated and what would, of course, make sense as the basis of all the scientificity that absorbs didactics: the learner.

Likewise, and following the line of this study focused on Spain, Order ECD/65/2015 (which regulates competences in primary, secondary, and baccalaureate education) establishes that competences in secondary education must be governed by the basic principles of lifelong learning, known as learning to know, learning to do, learning to be, and learning to live together (Delors 1996). This is decisive for offering training with which students align the knowledge acquired with their practical skills, emotions, feelings, attitudes or values, among other things. Furthermore, as regulated by (Royal Decree 1105/2014 2014) (which establishes the curriculum for secondary education and baccalaureate), the competences in secondary education "will be worked on with integrated activities that favour the learning of several competences at the same time" (p. 7). Clearly, in order to be able to carry out learning by competences, it is essential that these competences are addressed in all areas and subjects, since only in this way would it be possible to cater for the individuality of students and their all-around education. Therefore, in secondary education, a competencybased pedagogy is one that not only invites students to progress course after course, but also strives to make them increasingly autonomous, both in the acquisition of new learning and in the decisions they make in their lives. In the same way, with regard to the subjects of social sciences, geography, and history (belonging to the block of core subjects), the administration will be in charge of distributing the competences by determining "the common contents, the assessable learning standards and the minimum teaching time" (p. 7), and they must be equally configured according to this conceptual base curriculum. However, by virtue of this competency-based approach, teachers must also ensure that students can give shape and meaning to everything they have learnt.

Undoubtedly, the teaching and learning of social sciences, geography, and history has not differed from other subjects in terms of the way and manner in which they have been taught historically, since if the Spanish educational model (and, more specifically, the procedures used in the teaching of the core subjects) has been criticised for anything, it has always been for using old-fashioned methodologies, close to memorisation and transmission of knowledge from teacher to pupil, without the transversality, dynamism, 
and transcendence that is currently included and demanded by educational regulations. In this sense, what is requested by (national and international) regulations is a proposal that teachers redesign (or change) the activities that have been carried out in social sciences, geography, and history, and that through these modifications, and also through interdisciplinary work, the development of various competences (from among all the key competences proposed in the national corpus juris) is provided through these subjects.

Similarly, given that assessment has positioned itself as one of the primordial elements for the collection of information, as well as for the assessment of the learning achieved by students in their different educational stages, it is important to bear in mind the way in which these assessment processes have been carried out up to now, and their apparent transformation - at least from the regulatory point of view-with the emergence of competence-based learning. Broadly speaking, educational assessment systems are known for the value that is still attached to standardised assessment tests, which, generally speaking, are carried out on a specific day for all students (and almost certainly without greater opportunities), following standardised criteria, which, without following any scientific basis, ask all students to know the same thing depending on the educational stage they are studying (Muñoz and Araya 2017). It is precisely Order ECD/65/2015 that states that the assessment criteria will serve as a "reference to assess what the student knows and knows how to do in each area, being broken down into assessable learning standards" (p. 6989). The order states, in turn, that these standards will be assessable and measurable, allowing the academic performance of students to be graded. In this sense, and following what is stated in Article 7 (dedicated to the assessment of key competences), the importance of choosing strategies and instruments that assess students according to their performance is established. This means that while the learning standards must be linked to the competences they will promote, they must also contribute to an assessment as close as possible to the students' performance levels. In spite of this, the Organic Law on Education 8/2013 (for the improvement of educational quality (OLIQUE)), which also contains some of the fundamental principles for learning by competences (as it could not be otherwise, since it is the educational regulation on which the rest of Spanish educational regulations are based and erected), from the beginning of its preamble, disregards a position in which importance is given only to standardised tests (such as, for example, "This shows that when what matters are the data produced by tests configured in a common way for all students, with criteria established by the administration, as well as their design and implementation, in no case are the individual performances, the learning selected by teachers (which apparently should and could be different depending on the performance of their students), or the rhythms of each student being considered.") (OLE 2006; OLMLIQUE 2013; OLMOLE 2020).

\section{Materials and Methods}

\subsection{Objects}

The general objective of this study is to discover the perception that pupils in the 4th year of compulsory secondary education (ESO) have of the usefulness of the competences according to what they have learnt in their social sciences, geography, and history class; the difficulties they encounter in assimilating them; as well as the instruments used to assess the degree of attainment of these key competences.

In addition, three specific objectives are highlighted that aim to specify this general objective:

1. To differentiate the socio-demographic variables that condition the perception of the usefulness of the key competences according to what has been learnt in the subjects of geography and history.

2. To find out the relationship between the students' perception of the difficulty in acquiring key competences and their usefulness.

3. To identify significant differences in the degree of difficulty presented by the key competences in geography and history class with the instruments used for their assessment. 


\subsection{Design}

This research has been carried out using an instrument called Evaluation of the Perception of Social Science Competences (EPECOCISO) (Álvarez-Martínez-Iglesias et al. 2020) and following a design of quantitative methodology, specifically through the descriptive process, which is considered the most appropriate for this type of research. As stated by Sabariego and Bisquerra (2014), descriptive methods "seek to specify the properties, characteristics and important profiles of people, groups, communities or any other phenomenon that is subjected to analysis" (p. 114).

Likewise, taking as a starting point the key competences set out in the Royal Decree of the Spanish Government 1105/2014, as well as projects of an international nature (the Tuning project, DeSeCo project, the European 2020 Strategy, etc.), following an exploratory factor analysis - which enables the classification of the variables of a scale into thematic blocks-three of the seven factors that were initially proposed for carrying out this research and that were included in the validation of the EPECISOCO scale have been selected, as shown in Table 1.

Table 1. Rotated component (factor) matrix.

FACTOR 1

Perception of competences in terms of what has been learnt.
After studying social sciences, I think that the development of competence in linguistic communication is very useful, since with it I will be able, among other things, to use language to express my emotions, experiences and opinions, so that others can understand me (v1).

I consider the contents worked on in social sciences for the development of social and civic competence to be very valuable, as they have enabled me to be participative at a social level-taking part in elections, creating associations, etc. (v5).

What I learn in Social Studies helps me to understand how fundamental the competence to learn to learn is, as with it I am aware of what I know and what I need to learn in order to construct my own knowledge (v7).

As a result of my work in social sciences at school, when I read a document, it is very difficult for me to know how to differentiate the really important information from that which is only complementary or filler (v12).

It is very difficult for me to know how to or with what criteria I have to evaluate a creation to know if it is a work of art or something without value, using what we have studied in social sciences (v14).

With what I have learnt in social sciences, I usually find it difficult, and it generates a lot of insecurity, to try to face or assume the problems that happen to me on a daily basis (v16).

I consider taking an exam with short or multiple-choice questions in social sciences to be a good strategy to evaluate my knowledge and critical analysis of societies, their evolution, and the changes that have taken place in them (v21).

I think that taking an exam with essay questions in social sciences is a good strategy to evaluate my knowledge and skills (v23).

\section{FACTOR 3}

Perception of the instruments used to assess the degree of attainment of the competences.

\subsection{Sample}

The sample was selected by means of a purposive sampling process with a standard error of $0.7 \%$ for the total universe, according to the results of the STATSTM analysis (Hernández Sampieri et al. 2008). Out of a total population of 14,714 students in the 4 th year of compulsory secondary education enrolled in both public and private schools in the region of Murcia, a total number of 1714 students was obtained, after eliminating all those instruments containing errors (or missing data). In this sense, following the specialised literature, the sample size requirement was calculated as 996 subjects to be surveyed, a figure that was largely exceeded in the study (Creswell 2014).

Furthermore, it is important to highlight that this is a balanced sample in terms of the sex of the respondents, a practically equal group $\left(51 \% \sigma^{x} ; 49 \%\right.$ o $)$ whose ages are between 15 and 18 years old. Similarly, it is a reliable sample (because of the stability and consistency of what has been measured), and a valid one (because it measures what it is intended to measure). 
Finally, in order to seek the maximum representativeness of the sample, it should be noted that the members of the final sample come from a total of 18 secondary schools, distributed throughout the region of Murcia, Spain.

\subsection{Instrument}

The instrument used in this research is composed, on the one hand, of socio-demographic variables (gender, age, parents' level of studies, grade obtained and final grade, etc.) and, on the other, of the study items, all of them structured on a Likert scale on which the students had to choose the response with which they most identified ( $1=$ totally disagree; 2 = disagree; 3 = neither agree nor disagree; 4 = quite agree; 5 = totally agree; and NS = don't know). The results have been achieved following a scrupulous design, based on four main blocks: elaboration and content of the instrument's items, evaluation and analysis by expert judges in the area of knowledge of the research, validation, and application. With regard to the instrument, it can be affirmed that it has good psychometric properties (Maldonado 2015), yielding data that show the different significant relationships between the variables influencing the perception of the level of development of competences according to what has been learned in geography and history. As can be imagined for this type of study, permission was sought from the responsible academic authorities before starting the data collection.

\subsection{Data Analysis Procedure}

Firstly, in order to select the most significant factors, an exploratory factor analysis was carried out with the analysis software SPSS. To do this, it was necessary to apply the maximum likelihood method to the covariance matrix, as well as Varimax rotation. Once the results of these tests were obtained, the factorial solution was carried out without previously determining an established (maximum) number of factors, highlighting the significance of the three main factors of the study (Table 2).

Table 2. Descriptive statistics of the subscales.

\begin{tabular}{|c|c|c|c|}
\hline Scale & $\mathbf{N}$ & Median & D. Tip. \\
\hline $\begin{array}{l}\text { F1: Perception of the application of the acquisition of key } \\
\text { competences to life in society }\end{array}$ & 1422 & 3.3107 & 0.84607 \\
\hline F2: Perception of competences in terms of what has been learnt & 1422 & 3.5080 & 0.77057 \\
\hline $\begin{array}{l}\text { F3: Perception of the degree of difficulty in assimilating the } \\
\text { competences }\end{array}$ & 1422 & 2.5762 & 0.78134 \\
\hline $\begin{array}{l}\text { F4: Perception of the methodology used for the acquisition of } \\
\text { competences }\end{array}$ & 1422 & 3.6558 & 1.02768 \\
\hline $\begin{array}{l}\text { F5: Perception of the importance of mathematical competence in } \\
\text { social sciences }\end{array}$ & 1422 & 3.0038 & 0.94818 \\
\hline F6: Perception of the transfer of learning to a real situation & 1422 & 3.6309 & 0.92828 \\
\hline $\begin{array}{l}\text { F7: Perception of the instruments used to assess the degree of } \\
\text { achievement of competences }\end{array}$ & 1422 & 3.5723 & 0.79740 \\
\hline Valid & 1422 & & \\
\hline
\end{tabular}

Subsequently, we wanted to know the relationship between the selected factors. Establishing each factor as a single variable, we carried out Pearson's correlation and the cross-table test indicating the frequency of response scores in each of them.

In this sense, each of the variables in the disposition that is collected establishes a general response to the role of secondary schools in the development of competences and, more specifically, in the subjects of social sciences, geography, and history, all based on the experience and perception of secondary school students themselves, since the Varimax (Table 3 ) test showed the instrument to offer high validity and reliability. In this sense, if the KMO reached values below 0.6 , it would be considered inappropriate (and not relevant) to perform a factorial analysis; considering that in the case of this investigation, the KMO 
value is 0.926 , the instrument and subsequent analysis of the data is fully reliable and consistent.

Table 3. Total variance explained after rotation of the selected factors; rescaled matrix maximum likelihood extraction method.

\begin{tabular}{ccccccc}
\hline \multirow{2}{*}{ Factor } & \multicolumn{3}{c}{ Initial Self-Values } & \multicolumn{2}{c}{ Squared Load Extraction Sums } \\
\cline { 2 - 7 } & Total & $\begin{array}{c}\text { \% of } \\
\text { Variance }\end{array}$ & $\begin{array}{c}\text { Cumulative } \\
\text { \% }\end{array}$ & Total & $\begin{array}{c}\text { \% of } \\
\text { Variance }\end{array}$ & $\begin{array}{c}\text { Cumulative } \\
\text { \% }\end{array}$ \\
\hline 1 & 4229 & 58,131 & 58,131 & 4229 & 58,131 & 58,131 \\
2 & 3049 & 24,982 & 83,113 & 3049 & 24,982 & 83,113 \\
3 & 2764 & 4916 & 88,029 & & & \\
4 & 2657 & 3385 & 91,414 & & & \\
5 & 2508 & 3261 & 94,675 & & & \\
6 & 2419 & 2981 & 97,656 & & & \\
7 & 2374 & 2344 & 100 & & & \\
\hline
\end{tabular}

In addition, in order to achieve a more detailed and precise analysis, a two-dimensional contingency table test was also carried out, indicating the possible significant relationships between the socio-demographic variables and the variables comprising each of the factors. In this way, in order to ascertain the existing relationships between the variables under study, it was necessary as a preliminary step to differentiate two types of variables according to their nature, highlighting, on the one hand, nominal variables (which do not admit an order criterion) and, on the other, ordinal variables (in which, unlike nominal variables, only their qualification by order makes sense, since they do not present numerical modalities).

In order to detect the degree of dependence between the nominal socio-demographic variables and the items of the instrument, the chi-squared test was carried out (considering dependent those variables that met $p<0.1$ ), as well as Cramer's V test, which indicates the strength of the association between the variables, with 0 being independence and 1 being perfect dependence.

Apart from the type of tests performed, the same procedure was applied to the ordinal socio-demographic variables. Thus, the linearity test was applied to each one of them, allowing any indication of dependence between variables to be detected, eliminating-for this purpose-all those variables whose $p$ value exceeded $0.1(p>0.1)$, since when this figure was exceeded, any possibility of a relationship between the variables was ruled out. The Goodman and Kruskal gamma test was applied to the remaining variables. This test indicates the strength of the association between the variables, as well as the sign of the association. The coefficient has a range of -1 to 1 , with -1 being a perfect negative association, 0 being independence, and 1 being a perfect positive association (i.e., the closer the value is to -1 or 1 , the stronger the negative or positive association).

\section{Results}

This section presents the results obtained after carrying out the tests described above, divided by each of the factors of the EPECOCISO scale.

\subsection{Factor 1. Perception of Competences in Terms of What Has Been Learnt}

In order to respond to objective 1 of this study (to differentiate the socio-demographic variables that condition the perception of the usefulness of skills according to what has been learned in the subject of geography and history), analysis of the questionnaire items belonging to this factor has been carried out.

Specifically, there are eight items that question the contribution of the subject of geography and history to the improvement of the ability to use language to express emotions, experiences, and opinions in a way that is understandable to others (linguistic competence); engagement with the surrounding environment and with society (interaction with the physical environment competence); the skills and abilities to make more and/or better use 
of information and communication technologies (ICT competence); full participation in society (social and civic competence); understanding different realities and productions in the world of art and culture (cultural and artistic competence); as well as the awareness that everyone has of what they have learned and what they need to learn in order to continue building their own knowledge (learning to learn competence).

One of the most striking results is that gender conditions the response to all the items in this block, except the one related to ICT competence, with female students $(66 \%)$ being more appreciative of the value of the competences in terms of what they have learnt in geography and history class than male students (34\%). In the case of ICT competence, the percentage difference between pupils and students is not significant: $-54 \%$ and $46 \%$, respectively (Table 3).

Another of the results that can be drawn from this research is the significant relationship of dependence that exists between the degree of motivation for studying geography and history and the acquisition of competences, since according to the results, it can be affirmed that regardless of the pupil's sex, the greater the motivation for studying the subject, the greater the acquisition of learning and these competences by pupils. Similarly, the same occurs with the time dedicated to study and the final mark obtained after the assessment processes, with both variables showing a high degree of significant relationship with each of the variables in this factor. The main conclusion is that the greater the dedication to study, the higher the final mark obtained, resulting (following the student's perception) in a greater acquisition of all the competences worked on in this subject (Table 4).

On the other hand, being a repeater only yields significant results in the items related to language and ICT skills, as 79\% of the repeater students surveyed rate the acquisition of these two skills positively in geography and history class compared to the rest of the skills. Likewise, it is only this competence that has a significant relationship with the parents level of studies: the higher the parents' level of studies, the higher the student's perception of this subject.

Table 4. Cramer's V test. Perception of competences in terms of what has been learnt.

\begin{tabular}{cccccccc}
\hline & $\mathbf{v 1}$ & $\mathbf{v 3}$ & $\mathbf{v 4}$ & $\mathbf{v 5}$ & $\mathbf{v 6}$ & $\mathbf{v 7}$ & $\mathbf{v 8}$ \\
\hline Sex & $0.083^{* *}$ & 0.073 & $0.083^{* *}$ & $0.102^{* * *}$ & $0.147^{* * *}$ & $0.108^{* * *}$ & 0.072 \\
Repeater & $0.084^{* *}$ & $0.08^{*}$ & $0.06^{* *}$ & 0.023 & 0.056 & $0.075^{*}$ & 0.041 \\
$\begin{array}{c}\text { Study } \\
\text { motivation }\end{array}$ & $0.13^{* * *}$ & $0.099^{* * *}$ & $0.096^{* * *}$ & $0.116^{* * *}$ & $0.107^{* * *}$ & $0.112^{* * *}$ & $0.107^{* * *}$ \\
\hline Cramer V test: ${ }^{*}=p<0.1^{* *}=p<0.05^{* * *}=p<0.01$. & & & &
\end{tabular}

\subsection{Factor 2. Perception of the Degree of Difficulty in Assimilating the Competences}

In order to respond to objective 2 of this study (to find out the relationship between the students' perception of the difficulty of acquiring competences and their usefulness), the results obtained after analysing the variables belonging to this factor are presented, with the students being questioned about the difficulty they have in situations such as locating existing industries in an area or region, and about having the criteria to value and recognise works of art, differentiating the truly important information after reading a document or expressing their own ideas and listening to the ideas of others, the aim of dialogue, and reaching agreements to resolve conflicts.

In line with what has been described above, one of the results that can be extracted from the analysis of this factor is that, as in factor 1, gender is a conditioning factor in the response to each of the items in this factor, establishing a relationship between gender and the difficulty presented by the competences. Specifically, $85 \%$ of the respondents who find the least difficulty in the competences are female students, compared to $15 \%$ who are male students (Table 5). 
Table 5. Goodman and Kruskal gamma test. Perception of competences in terms of what has been learnt.

\begin{tabular}{cccccccc}
\hline & $\mathbf{v 1}$ & $\mathbf{v 3}$ & $\mathbf{v 4}$ & $\mathbf{v 5}$ & $\mathbf{v 6}$ & $\mathbf{v 7}$ & $\mathbf{v 8}$ \\
\hline Final Note & $0.2^{* * *}$ & $0.145^{* * *}$ & 0.04 & $0.1^{* * *}$ & $0.151^{* * *}$ & $0.161^{* * *}$ & $0.158^{* * *}$ \\
Time & $0.104^{* * *}$ & $0.078^{* * *}$ & 0.066 & $0.1^{* * *}$ & $0.118^{* * *}$ & $0.153^{* * *}$ & $0.126^{* * *}$ \\
N. Father & 0.009 & $0.035^{* *}$ & $-0.08^{* * *}$ & 0.031 & 0.032 & $0.061^{* *}$ & 0.016 \\
N. Mother & 0.05 & $0.073^{* *}$ & $-0.066^{* *}$ & 0.039 & 0.039 & $0.06^{* *}$ & $0.078^{* * *}$ \\
\hline Goodman and Kruskal gamma: ${ }^{*}=p<0.1^{* *}=p<0.05^{* * *}=p<0.01$. & & &
\end{tabular}

Goodman and Kruskal gamma: ${ }^{*}=p<0.1,{ }^{* *}=p<0.05,{ }^{* * *}=p<0.01$.

Another significant result of the analysis of this factor is that it shows the existence of a relationship between the difficulty of the competences for students and the final mark they think they will obtain. However, unlike in previous cases, and as can be seen in table $X$, this significance is negative (inverse), since the greater the difficulty students perceive the competences to be, the lower the mark they expect to obtain at the end of the course (Table 6).

Table 6. Cramer's V test. Perception of the degree of difficulty in assimilating the competences.

\begin{tabular}{cccccc}
\hline & $\mathbf{v 1 1}$ & $\mathbf{v 1 2}$ & $\mathbf{v 1 3}$ & $\mathbf{v 1 4}$ & $\mathbf{v 1 6}$ \\
\hline Sex & 0.034 & $0.109^{* * *}$ & $0.144^{* * *}$ & $0.12^{* * *}$ & $0.155^{* * *}$ \\
Repeater & 0.043 & $0.091^{* *}$ & $0.094^{* *}$ & 0.056 & 0.056 \\
Study motivation & $0.067^{*}$ & $0.073^{* *}$ & $0.089^{* * *}$ & 0.063 & 0.052 \\
\hline Cramer V test: $*=p<0.1^{* *}=p<0.05^{* * *}=p<0.01$
\end{tabular}

Cramer V test: ${ }^{*}=p<0.1,{ }^{* *}=p<0.05,{ }^{* * *}=p<0.01$.

\subsection{Factor 3. Perception of the Instruments Used to Assess the Degree of Attainment of the Competences}

Finally, the results derived from this factor are presented, the analysis of which attempts to fulfil objective 3 of this research (to identify the existence of significant differences in the degree of difficulty presented by the competences in the geography and history class with the instruments used for their assessment). To this end, two variables related to the assessment instruments used in this subject were analysed, which question students on the suitability of which type of examination (short questions/test-type vs. essay questions) they consider to be the best strategy for assessing the knowledge acquired.

In this factor, unlike the other two, there is no significant relationship between gender and the perception of the assessment instruments used. However, there is a significant relationship with the students' motivation to study, with those students who are more motivated to study the subject preferring short test-type exams.

On the other hand, as in factor 2 , there is a significant negative relationship when it comes to the final mark and the instruments used for assessment, indicating that the higher the mark obtained by the student, the worse they rate the assessment instruments used (Tables 7 and 8).

Table 7. Goodman and Kruskal gamma test. Perception of the degree of difficulty in assimilating the competences.

\begin{tabular}{cccccc}
\hline & $\mathbf{v 1 1}$ & $\mathbf{v 1 2}$ & $\mathbf{v 1 3}$ & $\mathbf{v 1 4}$ & $\mathbf{v 1 6}$ \\
\hline Final Note & $-0.088^{* * *}$ & $-0.165^{* * *}$ & $-0.158^{* * *}$ & $-0.044^{*}$ & $-0.094^{* * *}$ \\
Time & $0.008^{* *}$ & $-0.042^{* *}$ & -0.022 & -0.038 & $-0.048^{*}$ \\
N. Father & -0.027 & $-0.125^{* * *}$ & $-0.086^{* * *}$ & -0.043 & -0.048 \\
N. Mother & -0.027 & $-0.064^{* *}$ & $-0.101^{* * *}$ & $-0.066^{* * *}$ & $-0.062^{*}$ \\
\hline Goodman and Kruskal gamma: ${ }^{*}=p<0.1^{* *}=p<0.05^{* * *}=p<0.01$. & &
\end{tabular}


Table 8. Cramer's V test. Perception of the instruments used to assess the degree of attainment of the competences.

\begin{tabular}{ccc}
\hline & $\mathbf{v 2 1}$ & $\mathbf{v 2 3}$ \\
\hline Sex & 0.062 & $0.085^{* *}$ \\
Repeater & 0.045 & 0.065 \\
Study motivation & $0.075^{* *}$ & $0.108^{* * *}$ \\
\hline Cramer's V test: $^{*}=p<0.1^{* *}=p<0.05,{ }^{* * *}=p<0.01$. &
\end{tabular}

It can also be affirmed that there is a relationship between the difficulty students perceive in acquiring competences and the assessment instruments used, since the greater the difficulty students perceive in acquiring these competences, the greater the disagreement they show with the assessment carried out and the instruments used for it.

Finally, it is essential to note the relationship found in Tables 4, 6 and 8. This relationship is significant above all with the gender variable and motivation to study. It is observed that they are closely related, since to the extent that they have an adequate perception of the competences as learned (Table 3), the difficulty they perceive of the competences is lower (Table 4), which translates into a positive perception of the adequacy of the means in the equation (Table 7). The same is true of the final mark variables, which are shown in Tables 5, 7 and 9. The higher the final mark, the better the students' perception of the competences in terms of what they have learnt, the less difficult it is, and the more relevant the means of assessment used seem to them.

Table 9. Goodman and Kruskal gamma test. Perception of the instruments used to assess the degree of attainment of the competences.

\begin{tabular}{ccc}
\hline & $\mathbf{v 2 1}$ & $\mathbf{v 2 3}$ \\
\hline Final Note & $-0.14^{* * *}$ & $0.239^{* * *}$ \\
Time & -0.024 & $0.062^{* * *}$ \\
N. Father & -0.039 & $0.06^{* *}$ \\
N. Mother & -0.017 & $0.052^{*}$ \\
\hline
\end{tabular}

Goodman and Kruskal gamma: ${ }^{*}=p<0.1,{ }^{* *}=p<0.05,{ }^{* * *}=p<0.01$.

\section{Discussion}

In light of these results, it seems that the students' perception is a key factor in carrying out the teaching-learning process through the competence-based approach. In view of Table 1, the selected factors determine the relevance of the competences worked on in the areas of social science, geography, and history through the thoughts of secondary school pupils, and determine their level of acquisition, the usefulness they attach to them in their immediate environment, the importance they attach to them, as well as their value and interest in them. Furthermore, through the second and third factors, an approximation to quality education is made by highlighting the degree of development of key competences in the selected area and their transposition into the lives of young people, as well as the dissatisfaction shown with the development of assessment processes. In this sense, we realise that pupils have many difficulties in identifying the key competences and carrying out learning through this approach.

4.1. The Perception of the Usefulness of the Key Competences According to What Has Been Learnt in the Subject of Geography and History

At present, students themselves, dragged along by a society whose mentality is that of minimum effort, and which promotes mechanical and repetitive processes to the detriment of procedures and attitudes, are reluctant to engage in this type of teaching. They find it more complicated, because they have to break with what they have been doing up to now, since learning by competences requires a change in the way of studying and working on the contents of the subject. 
Moreover, on many occasions, this difficulty can be increased because teachers, in their almost unhealthy obsession with delivering what is planned, forget to provide the coherence needed to implement the competency-based approach. This results in a sense of confusion and anxiety on the part of the learner that makes them fail to understand the purpose of learning, and therefore, they end up detesting it (Coopmans et al. 2020; Sáez-López et al. 2021). This feeling is exacerbated when the lack of coherence, in addition to the methodological section, reaches the assessment section, since, as the results show, there is no correspondence between the students' expectations and the reality they actually obtain.

\subsection{Differences in the Degree of Difficulty Presented by the Key Competences in Geography and History Class with the Instruments Used for Their Assessment}

Among all these questions, the most pressing response is, without a doubt, that all teachers should distance themselves from classificatory assessment tests (Rodríguez 2017), which are incapable of assessing all those aspects that seem to be related to learning by competences (attitudes, values, emotions, individuality, and needs, among others) or, what is the same, the consideration of the principle of attention to diversity (Molina Saorín 2017). This is because simply maintaining these assessment systems would mean continuing to reward those who memorise (surely for a limited time) without being able to put this learning into practice, as opposed to those who do not memorise but learn slowly and progressively (and who will certainly maintain this learning over time). All of this is done in order to achieve some apparently required minimums, although they are not included in any regulations as compulsory, and they rather seem to be the result of that outdated tradition in which teachers, perhaps due to ignorance of the regulations, maintain decrepit methodological and evaluative patterns, together with shallow behaviour on the part of the administration for the elaboration of educational regulations with common actions and univocal meanings.

\subsection{Relationship between the Students' Perception of the Difficulty in Acquiring Key Competences and Their Usefulness}

From this perspective, and on the basis of the research carried out, it is easy to understand that full compliance with the implementation of competency-based learning (Serrano González-Tejero and Parra 2011), at least from the perspective proposed, should mean that no student would have to overcome insurmountable barriers, such as being assessed without distinction, displaced (depending on their performance), assessed according to what they know (or do not know) how to do, or assessed with better future projections only if they can overcome each of the steps that the administration has set as essential minimums. In this sense, it is absolutely necessary to highlight that, as in the case of other areas or subjects, the normative analysis of learning by competences is lengthy; with regard to the research presented, the innovative nature of the same is underlined, as it is an enquiry into the perception of students, thus highlighting a twofold projection. On the one hand, a voice is given to secondary school pupils themselves, as they are the ones who will answer the questions that will ultimately be analysed, and, on the other hand, by focusing its scope of study on the competences worked on in social sciences, geography and history, the research approaches a field of study with little specialised, and almost unknown, literature.

\section{Conclusions}

Consequently, through the approaches indicated by means of theoretical enquiry and in harmony with the analysis resulting from this research, there appears to be an antithesis insofar as the educational regulations analysed raise aspects that contradict each other, specifically in articles that should be entirely concordant, as has been reflected in the aforementioned articles. Similarly, it seems to be the case that it is not known who is responsible for facilitating the development of these competences (Miralles and Gómez 2020; Gómez and Miralles 2016), since, on the one hand, it is made clear that teachers will 
be responsible for selecting and accommodating them during the development of their subjects, but, on the other hand, a catalogue of minimum standards is established (by the administration), with barriers for those pupils who are not capable of surpassing them. It is therefore important to highlight who is responsible for developing competences, to what extent students are the real beneficiaries of competence-based learning, and in which cases competences can be assessed through standardised tests, since it is assumed that what they are learning, students will put into practice in their daily lives. (Ortega-Sánchez and Pagès 2020; Ortega-Sánchez and Olmos 2018).

Author Contributions: Conceptualization, J.M.Á.M.-I. and J.M.S.; data curation, J.M.Á.M.-I.; formal analysis, J.M.Á.M.-I. and J.M.S.; funding acquisition, F.J.T.C., and P.M.M.; investigation, F.J.T.C., J.M.Á.M.-I., and J.M.S.; methodology, F.J.T.C., and P.M.M.; project administration, P.M.M.; resources, F.J.T.C.; writing-review and editing, J.M.Á.M.-I., P.M.M., and J.M.S. All authors have read and agreed to the published version of the manuscript.

Funding: This research has been financed by the projects "The evaluation of competencies and the development of cognitive abilities on history in Obligatory Secondary Education" (EDU2015-65621C3-2-R), subsidized by the Spanish Ministry of Economy and Competitiveness and co-financed with EU ERDF funds; and "Methodological concepts and active learning methods to improve teachers' teaching skills" (PGC2018-094491-B-C33), subsidized by the Spanish Ministry of Science and Innovation and Spanish Agency of Research, and co-financed with EU ERDF funds.

Institutional Review Board Statement: The study was conducted according to the guidelines of the Declaration of Helsinki, and approved by the Ethics Committee of University of Murcia 00325 April 2017.

Informed Consent Statement: Informed consent was obtained from all subjects involved in the study. Data Availability Statement: Not applicable.

Acknowledgments: Acknowledgements to the Spanish Ministry of Science and Innovation, and the Spanish Agency of Research.

Conflicts of Interest: The authors declare no conflict of interest.

\section{References}

Álvarez, José María, Díaz Yonatan, and Molina Jesús. 2021. The Cuomo Code. Las Fábulas de María: Una Niña a la Que no le Gustaba la Escuela. Madrid: Dykinson.

Álvarez-Martínez-Iglesias, José-María, Francisco-Javier Trigueros-Cano, Pedro Miralles-Martínez, and Jesús Molina-Saorín. 2020. Assessment by Competences in Social Sciences: Secondary Students Perception Based on the EPECOCISO Scale. Sustainability 12: 10056. [CrossRef]

Argudín, Y. 2005. Competency-Based Education: Notions and Background. Trillas: C México.

Bruner, J. S. 1987. The Importance of Education. Barcelona: Paidós, pp. 17-33.

Coopmans, Manja, Geert Ten Dam, Anne Bert Dijkstra, and Ineke Van der Veen. 2020. Towards a Comprehensive School Effectiveness Model of Citizenship Education: An Empirical Analysis of Secondary Schools in The Netherlands. Social Sciences 9: 157. [CrossRef]

Creswell, John W. 2014. A Concise Introduction to Mixed Methods Research. Thousand Oaks: Sage, vol. 11, pp. 1-5.

Delors, J. 1996. Report to UNESCO of the International Commission on Education for the Twenty-First Century. In EEUU Learning: The Treasure Within. Chaired by Jacques Delors. Paris: Unesco Pubishing.

Gómez, Cosme, and Pedro Miralles. 2016. Historical skills in compulsory education: Assessment, inquiry based strategies and students' argumentation. Journal of New Approaches in Educational Research 2: 1-6. [CrossRef]

González, Julia, and Robert Wagenaar, eds. 2003. Tuning Educational Structures in Europe. Bilbao: University of Deusto.

Hernández Sampieri, R., Fernández Collado, and L. C. y Pilar Baptista. 2008. Fundamentos de Metodología de la Investigación. Madrid: Mc Graw Hill, pp. 10-30.

Maldonado, C. 2015. Thinking complexity, thinking as synthesis. Cinta Moebio 54: 313-24. [CrossRef]

Miralles, P., and C. J. Gómez. 2020. Students' historical thinking and its relationship with competences. In Educación Histórica para el siglo XXI. Epistemological and Methodological Principles. Edited by N. Ibagón, R. Silva, A. Santos and R. Castro. Santiago de Cali: Univalle/Universidad ICESI. [CrossRef]

Monarca, H., and N. Fernández González. 2020. Reconfiguration of Meanings about Education in Spain from the New Education Law (LOMCE). In External Evaluations: Mechanisms for the Configuration of Representations and Practices in Education. Madrid: Universidad Autónoma de Madrid, Available online: https:/ /repositorio.uam.es/bitstream/handle/10486/692407/reconfiguracion_monarca_ 2020.pdf?sequence $=1$ (accessed on 30 March 2021). 
Muñoz, D. R., and D. H. Araya. 2017. The challenges of competency-based assessment in education. Educação e Pesquisa 43: $1073-1086$. [CrossRef]

Núñez, Nemecio, and Pedro G. Palacios. 2004. La superación docente continua: Algunos criterios para su perfeccionamiento. Revista Iberoamericana de Educación 35: 1-8. [CrossRef]

OECD. 2010. Regional Development Policies. Paris: OECD Publishing. [CrossRef]

OECD. 2018. The Future of Educations and Skill. Paris: Publishing, Available online: https//www.oecd.org/education/2030/E2030\% position\%20paper\%20 (accessed on 30 March 2021).

OECD. 2019. OECD Skills Strategy 2019. Skills for a Better Future. Madrid: OECD Publishing and Fundación Santillana. [CrossRef]

OLE. 2006. Organic Law 2/2006, of 3 May, on Education. BOE, 106, of 4 May 2006. Available online: https://www.boe.es/buscar/pdf/ 2006/BOE-A-2006-7899-consolidado.pdf (accessed on 30 March 2021).

OLMLIQUE. 2013. Organic Law 8/2013, of 9 December, for the Improvement of Educational Quality (LOMCE). Official State Gazette, 295. December 10. Available online: https://www.boe.es/buscar/pdf/2013/BOE-A-2013-12886-consolidado.pdf (accessed on 30 March 2021).

OLMOLE. 2020. Organic Law 3/2020, of 29 December, Which amends Organic Law 2/2006, of 3 May, on Education. Official State Gazette, 340, 30 December 2020. Law 8/2013, of 9 December, for the Improvement of Educational Quality. Official State Gazette 295: 3-64. Available online: https://www.boe.es/boe/dias/2020/12/30/pdfs/BOE-A-2020-17264.pdf (accessed on 30 March 2021).

Ortega-Sánchez, Delfín, and Rafael Olmos. 2018. Los Problemas Sociales Relevantes o las Cuestiones Sociales Vivas en la Enseñanza de las Ciencias Sociales. En Contribuciones de Joan Pagès al Desarrollo de la Didáctica de las Ciencias Sociales, la Historia y la Geografía en Iberoamérica. Edited by Miguel Ángel Jara and Antoni Santisteban. Cipolletti: Universidad de Comahue-Universitat Autònoma de Barcelona, pp. 203-14.

Ortega-Sánchez, Delfín, and Joan Joan Pagès. 2020. The purpose of history teaching and the curricular inclusion of social problems from the perspective of trainee primary school teachers. Social Sciences 9: 9. [CrossRef]

Rauner, Mary. 1999. La UNESCO como organismo portador de información sobre educación cívica. Revista de Desarrollo Educativo 19: 91-100.

Rodríguez, E. A. 2017. Towards an authentic assessment of the reading of literary works in secondary school students. Diálogos Educativos Electronic Journal 10: 2-13.

Royal Decree 1105/2014. 2014. Royal Decree 1105/2014 of 26 December, Establishing the Basic Curriculum for Compulsory Secondary Education and the Baccalaureate. Official State Gazette, 1-35. Available online: https:/ /www.global-regulation.com/ translation/spain/1447540/royal-decree-1105---2014\%252c-of-26-december\%252c-which-establishes-the-basic-curriculumof-compulsory-secondary-education-and-secondary-education.html (accessed on 30 March 2021).

Rychen, Dominique Simone, and Laura Hersh Salganik. 2003. Highlights from the OECD Project Definition and Selection Competencies: Theoretical and Conceptual Foundations (DeSeCo). Available online: https://eric.ed.gov/?id=ED476359 (accessed on 30 March 2021).

Sabariego, M., and R. Bisquerra. 2014. The research process (part 1). In Metodología de la Investigación Educativa. Madrid: La Muralla, pp. 89-125.

Sáez-López, José-Manuel, María-Concepción Domínguez-Garrido, María-del-Castañar Medina-Domínguez, Fuensanta Monroy, and Raúl González-Fernández. 2021. The Competences from the Perception and Practice of University Students. Social Sciences 10: 34. [CrossRef]

Molina Saorín, Jesús. 2017. La Discapacidad Empieza en tu Mirada: Las Situaciones de Discriminación por Motivo de Diversidad Funcional: Escenario Jurídico, Social y Educativo. Madrid: Delta Publicaciones.

Serrano González-Tejero, José Manuel, and Rosa María Pons Parra. 2011. Constructivism today: Constructivist approaches in education. Electronic Journal of Educational Research 13. Available online: http://redie.uabc.mx/vol13no1/contenido-serranopons.html (accessed on 25 November 2018). 


\title{
Educational Intervention through a Board Game for the Teaching of Mathematics to Dyslexic Greek Students
}

\author{
Efstratios Malliakas $^{1, *}$, Noelia Jiménez-Fanjul ${ }^{2}\left(\mathbb{D}\right.$ and Verónica Marín-Díaz ${ }^{1}$ (D) \\ 1 Department of Education, University of Cordoba, 14004 Córdoba, Spain; vmarin@uco.es \\ 2 Mathematics Education, Department of Mathematics, University of Cordoba, 14004 Córdoba, Spain; \\ noelia.jimenez@uco.es \\ * Correspondence: z62malme@uco.es
}

check for

updates

Citation: Malliakas, Efstratios,

Noelia Jiménez-Fanjul, and Verónica

Marín-Díaz. 2021. Educational

Intervention through a Board Game for the Teaching of Mathematics to Dyslexic Greek Students. Social Sciences 10: 370. https://doi.org/ 10.3390/socsci10100370

Academic Editor:

Delfín Ortega-Sánchez

Received: 16 August 2021

Accepted: 26 September 2021

Published: 30 September 2021

Publisher's Note: MDPI stays neutral with regard to jurisdictional claims in published maps and institutional affiliations.

Copyright: (c) 2021 by the authors. Licensee MDPI, Basel, Switzerland. This article is an open access article distributed under the terms and conditions of the Creative Commons Attribution (CC BY) license (https:// creativecommons.org/licenses/by/ $4.0 /)$.

\begin{abstract}
The main purpose of this study was to investigate the effectiveness of an intervention strategy in teaching mathematics based on a board game, using the curriculum of mathematics in Greece, called Adapted Analytical Programs (A.A.P.). This research was conducted on secondary students in Greek General Schools over a period of five weeks. One hundred and twenty-four 12-to13-year-old dyslexic students participated in the study. A pre-test and a post-test with exercises in the chapter of fractions were used to assess the improvement in students' performance. The assessment showed that this intervention strategy improved dyslexic students' performance. The results of the research indicate that integrating a board game adapted to mathematics into the secondary school curriculum could have positive effects on dyslexic students.
\end{abstract}

Keywords: mathematics; dyslexia; analytical programs; intervention

\section{Introduction}

The Yemen Dyslexia Association (Emerson 2015) defines dyslexia as 'A functional disorder of the left side of the brain. It causes difficulty in reading, writing or mathematics associated with other symptoms, such as weakness in short-term memory, ordering, movements and directions awareness'. People with dyslexia find it difficult to connect speech with writing because they have deficiencies in the phonological component of the language. The difficulty of accurately and easily deciphering can affect reading comprehension and vocabulary development. Spelling difficulties can affect the production of written speech as well. Within this context, dyslexia is not a sign of low intelligence, laziness or poor eyesight. On the contrary, it occurs in the whole range of mental abilities of the individual. According to the law on education of people with disabilities (Disabilities Education Act), the functional definition of dyslexia is 'special learning disability' (Futterman and Futterman 2017).

It is a disorder in one or more of the basic psychological processes involved in understanding or using language, speech or writing and can manifest itself in the imperfect ability of a person to hear, think, speak, read, write or carry out mathematical calculations. The most persistent problem, however, seems to be diction (Roitsch and Watson 2019). More specifically, when a student with dyslexia begins to learn how to read, they have difficulty with the level of voice or sound, which adversely affects spelling and reading. Secondary consequences may include reading comprehension problems and reduced reading experience, which may impede the development of vocabulary and background knowledge (Roitsch and Watson 2019).

Dyslexia is one of the most common neurodevelopmental disorders in children. About $5-10 \%$ of school-age children suffer from dyslexia, which is more common in boys (Huang et al. 2020a); the aetiology and pathogenesis of dyslexia have not yet been clearly defined. Rüsseler et al. (2017) have found that children with dyslexia may be associated with genetic and/or brain injuries, brain dysplasia, malnutrition and so on. External factors, such as 
school, family environment, childhood education, living environment and other factors, can also affect children's reading skills. According to Huang et al. (2020b), children's living and learning environment has significantly affected their learning skills. The result is that children with dyslexia have negative emotions about their self-image and relationships with classmates and family. In terms of social interaction, children with dyslexia lack social skills due to stress or low self-esteem and have problems with adapting themselves to social circumstances (Abd Rauf et al. 2020). Additionally, the incidence of anxiety and depression in children with dyslexia is also higher than in typical children, with more negative behaviours, higher suicide rates and increased antisocial behaviours (Abd Rauf et al. 2018).

Muhamad et al. (2016) support that 'teachers enjoy teaching maths to students with dyslexia but find that adequate training, teaching experience, and exposure to multiple teaching strategies are required for success'. According to Macrae et al. (2003), the student may also have difficulty with numerical facts, retrieving the theorems and the formulas that are needed and even more with mathematical relationships. In multi-step problems, students often lose their way or skip sections and do not consider all the relevant aspects of the problem. This results in their inability to make the necessary combinations and achieve a final solution. In support of this, Witzel and Mize (2018), in their research, corroborate that having legislative support for students with dyslexia and dyscalculia is beneficial. Employing empirically validated assessments and strategies is even better. According to them, teachers and teacher candidates alike must learn how to evaluate and guide students with dyslexia. In addition, in real teaching situations, dyslexic students appear to have less potential when asked to address certain assignments. Additionally, mathematics is reinforced through practice. For this reason, towards the end of a lesson the teacher often assigns a handout or some exercises from the official textbook for students to complete at home. While typical students may have completed the task before the next lesson, the dyslexic student will have completed perhaps three-fourths, and, in effect, they receive less reinforcement. This leads to a decrease in the student's confidence in their ability to complete a set task. Furthermore, as Grehan et al. (2015) state, there is no one standard approach to providing support in mathematics which will cater for the needs of all students. Macrae et al. (2003) state that dyslexia may also cause slow reading, or the student may not understand what they have read. Finally, frequent problems arise when learners are asked to associate a concept with its symbol or function.

All the aforementioned reasons attest that a significant number of students with learning disabilities have certain difficulties in mathematics. Cook et al. (2019) state that 'the research in mathematics is underdeveloped in such a way that special educators as well as general educators must make instructional decisions based on the best evidence when planning instruction for students with learning disabilities'. These students' have difficulties in assimilating and understanding at the same pace during the lesson. Frequent repetitions are needed and, of course, someone who explains what the teacher says in simpler ways. In another study (Shin and Bryant 2016), it is mentioned that students can become more proficient problem solvers if they are able to use models to represent the structure of the problem in a diagram or graphic organizer. Researchers (Bryant et al. 2014) have pointed out that even the most struggling students can benefit from a small group intervention that is intensive, strategic, and explicit. Furthermore, according to Robinson (2017), effective models of inclusive teacher education will be likely to adopt a collaborative approach to professional learning and development. So, common educational programs for different groups of people with special educational needs are likely to be found, to a greater or lesser extent, in every educational system. Educational programs can be used in every level of education so that they can help students with special needs. For example, in schools with a large student population, the number of students with special needs is adequate to form homogeneous classes of learners who share the same level of learning difficulties. However, in educational systems which have only recently begun to provide targeted special education services to people with physical, mental, and multiple disabilities, this 
situation is increasing dramatically. An example of such a system is the Greek education system. In the last decade, it has been observed that the number of students with physical, mental, or multiple disabilities participating in educational programs of the Ministry of Education, mainly at the level of secondary education, has multiplied (Papadimitriou and Tzivinikou 2019).

This research aims to investigate the effectiveness of the APS of the Greek Ministry for students with dyslexia in the course of mathematics in high school. In the same vein, it is directed towards indicating the need to design more comprehensive analytical programs for dyslexic students or to improve and supplement the existing ones. Accordingly, the grounds towards more effective teaching of mathematics to students with special needs will be set. Furthermore, it must be mentioned that a comprehensive presentation and comparison between an intervention in mathematics with the Adapted Analytical Programs for students with dyslexia is included. This happens because, in Greece, there are two analytical programs for every subject, one for students with special needs named 'Adapted Analytical Programs' (A.A.P.) and one for typical students named 'Analytical Programs'. The A.A.P. for students with special needs, which refer to dyslexic students as well, contain exercises with graphs and pictures. The Ministry of Education publishes them to guide the teachers on how implement each lesson.

\section{Materials and Methods}

\subsection{Objective/Research Questions and Hypotheses Control}

This research aims to examine the performance of students with dyslexia who are taught mathematics according to the A.A.P. In essence, the researcher aims to investigate the need to design more comprehensive analytical programs for dyslexic students or to improve and supplement the existing ones, with the ultimate goal of improving the field of special education and effectively teaching mathematics to students with special needs. Consequently, the objectives that arise from the literature review and the context in which they will be explored are:

- Identifying difficulties of students with dyslexia in mathematics.

- Critical evaluation of A.A.P. (adapted analytical programs) of mathematics for students with dyslexia.

- $\quad$ Exploring if an intervention based on a board game using A.A.P. helps dyslexic students.

Achieving these objectives requires answering the following questions which account for the research questions:

- $\quad$ Are the A.A.P. helping students with dyslexia to understand mathematics?

- Are the exercises and suggested activities from the A.A.P. sufficient for such an adapted teaching?

- $\quad$ Does the intervention program using A.A.P. help dyslexic students?

- Is there a significantly positive relationship between the performance of dyslexic students and their attendance of the A.A.P.?

- Is there a significantly positive relationship between the performance of dyslexic students and their participation in the intervention program?

\subsection{Participants}

The participants of the present study were 124 students who had been diagnosed with dyslexia. Informed consent was obtained from the parents of all children. The students had been diagnosed with dyslexia by their Local Certified Government Agencies. The control group (C.G.) consisted of 61 students with dyslexia and the experimental group (E.G.) consisted of 63 students with dyslexia. In Table 1, the number of students of each group and the type of each student are presented analytically. The selected samples randomly consisted of seventh graders, aged 12-13 years old, from many different schools in Greece, mainly from the region of Attica and Lesvos Island. The students were selected by the principal and the teachers of each school and agreed to participate with consent provided by their parents. The selection criteria of the sample were determined both by the principal 
of each school and the responsible teachers of each class, who indicated the students diagnosed with dyslexia.

Table 1. Gender of each Group.

\begin{tabular}{cccc}
\hline & C.G. & E.G. & Total \\
\hline Male & 32 & 135 & 67 \\
Female & 29 & 28 & 57 \\
Total & 61 & 63 & 124 \\
\hline
\end{tabular}

(C.G. refers to Control Group and E.G. refers to Experimental Group).

\subsection{Variables-Measures}

In Table 2, variables' denomination and their corresponding categorization are shown.

Table 2. Independent variables.

\begin{tabular}{cc}
\hline Variables & Categories \\
\hline Gender & Male \\
Method of teaching & Female \\
\hline
\end{tabular}

(A.A.P. refers to Adapted Analytical Programs).

In Table 3, dependent variables' denomination and their corresponding dimension and definition are shown.

Table 3. Dependent variables.

\begin{tabular}{ccc}
\hline Variables & Definition & Dimension \\
\hline $\begin{array}{c}\text { Evaluation of performance of } \\
\text { D.S. in pre-test }\end{array}$ & $\begin{array}{c}8 \text { questions with a } \\
\text { scale 0-20 }\end{array}$ & $\begin{array}{c}\text { Performance of D.S. in the chapter of } \\
\text { fractions in mathematics before } \\
\text { teaching A.A.P./intervention }\end{array}$ \\
\hline $\begin{array}{c}\text { Evaluation of performance of } \\
\text { D.S. in intervention program }\end{array}$ & $\begin{array}{c}25 \text { questions with a } \\
\text { scale 0-25 }\end{array}$ & $\begin{array}{c}\text { Performance of D.S. in the chapter of } \\
\text { fractions in mathematics during the } \\
\text { intervention program }\end{array}$ \\
\hline $\begin{array}{c}\text { Evaluation of performance of } \\
\text { D.S. in post-test }\end{array}$ & $\begin{array}{c}8 \text { questions with a } \\
\text { scale 0-20 }\end{array}$ & $\begin{array}{c}\text { Performance of D.S. in the chapter of } \\
\text { fractions in mathematics after teaching } \\
\text { A.A.P./intervention }\end{array}$ \\
\hline
\end{tabular}

(D.S. refers to Dyslexic Students).

\subsection{Design of the Research}

A quantitative approach has been adopted because the collection of information drawn from the data to investigate the research questions, was based on numerical measurement and statistical analysis in order to determine a pattern of performance in mathematics. Based on this, the quantitative research offered a chance of generalizing the results obtained in a broader sense, although controlling the groups studied in terms of their number and size should be considered. Similarly, it has given the opportunity of reproducing and an accurate perspective on specific points of these groups, thus facilitating comparison with other studies of a similar nature (López-Hernández et al. 2005).

This is carried out as a correlational study, the purpose of which was to examine the relationship between two categories or variables in a specific context (López-Hernández et al. 2005). It is attempted to measure the degree of the relationship between dependent and independent variables. These were the performance of dyslexic students attending the A.A.P. against their performance attending an alternative intervention program based on a board game. 


\subsection{Procedure}

All data during the pre-test, intervention, and post-test phases of the study were collected at three time points over a period of 3 months, through filling out forms in the classroom. The filling out of forms lasted for a total of 7 teaching hours (45 min) for every student and took place during the scholar time. More specifically, the whole procedure contained 1 teaching hour at pre-test, $10 \times 22 \mathrm{~min}$ for intervention/teaching of the analytical programs and 1 teaching hour at post-test. The forms were devised in order to collect the answers of the target students. The dependent variable was the total knowledge/performance of each student. The designed test about fractions is intended to measure students' knowledge of fractions and subsequently their performance.

Initially, the parents of students with dyslexia were informed about the basic principles and aims of this research, giving their signed consent. Concerning the 61 dyslexic students who were assigned to the Control Group were going to attend only the A.A.P., while the remaining 63 students who were in the Experimental Group were going to participate in the alternative intervention. The next step was to inform the principal of the school and the teachers and to ensure that they could participate in this project. A time and date were set for the teaching through the A.A.P. to the C.G. and another time and date for the implementation of the intervention to the E.G. It should be mentioned that all the students knew that they could leave the project any time. This option provided them with a sense of safety, stability, and control over the intervention process.

\subsubsection{Pre-Test}

Pre-test was carried out before the intervention and the teaching of A.A.P. and involved all students filling out forms for 1 teaching hour ( $45 \mathrm{~min}$ ). They were asked to answer some questions about the fractional operations and a combination of them in a problem in two stages. There were exercises of increasing difficulty and a variety of arithmetic operations so that the student can be examined in all thematic units. All the students answered the questions prior to the teaching of the topic relying only on the knowledge they had from previous classes. The pre-test showed the performance and the level of acquisition of each student in fractions. A graded scale of 0-20 corresponded to each student. There were 8 exercises, and each student could reach 20 points if they answered all questions correctly and 0 point if they answered everything wrong. Each correct answer was giving 1 point and each incorrect answer was giving 0 points. After the collection of pre-test data, the students with dyslexia were allocated to the C.G. and to the E.G.

\subsubsection{Intervention}

The board game was implemented over a period of 5 weeks on a weekly basis consisting of 10 sessions. Each session lasted $22 \mathrm{~min}$ and took place twice every week after the end of classes, so that the students, an empty and quiet classroom and the researcher were available. Concerning the alternative way of teaching, it is an original learning game that promotes an alternative teaching-learning method through questions and solved examples printed on cards to students with dyslexia. The subject matter of the tool deals with a specific part of the curriculum of the Mathematics A' Gymnasium, the 'Fractions'. More specifically, it deals with the research area of fractions, and its learning objectives are divided into 5 learning areas:
1. Quantity
2. Equality of fractions
3. Base of 10
4. Algebraic and Geometric Thought
5. Forms of a fractional number

Regarding the design of the game, a dashboard has been formed which is divided into 5 coloured areas, depending on the difficulty and the research area the students deal with (Figure 1). Each thematic area corresponds to 5 closed-question cards with 5 similar solved examples on the backside of each card (Figure 2). Therefore, the game consisted of 25 
questions in total and 25 solved examples for each question. The difficulty of the exercises is tiered as the students move on to each topic, and there is a variety of arithmetic operations so that the students can go through all the questions and be assessed. The transition from area to area takes place only with the process of completing the respective learning area. The aim of the participant is to cover the full range of exercises which are included in the specific thematic area of fractions modules. It should be noted that the choice of exercises from the researcher has been meticulously made to avoid obstacles or difficulties for students with dyslexia, after an extensive literature review of dyslexia and its correlation with mathematics. The dashboard and the two sides of one card is presented below.

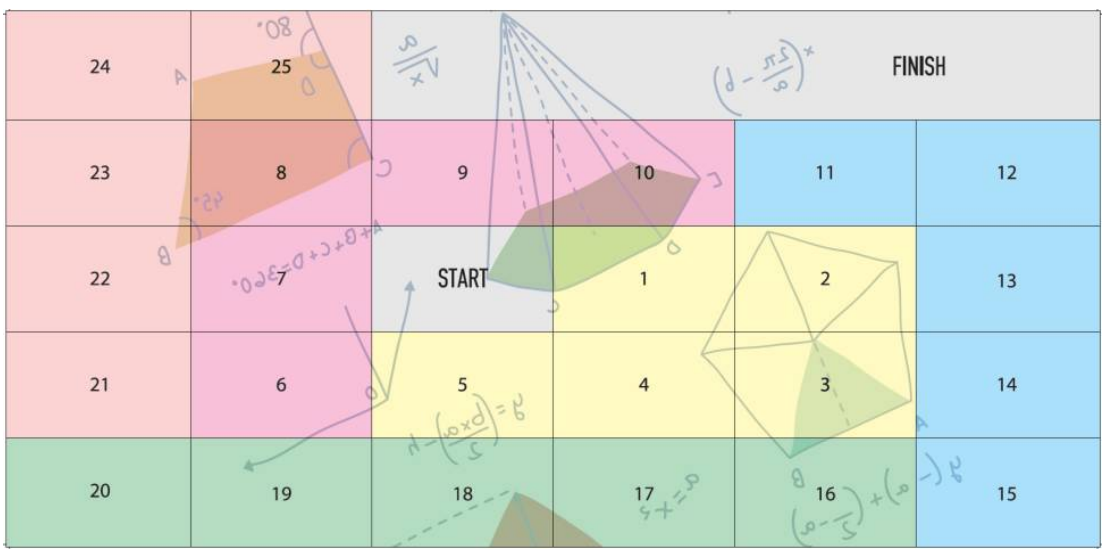

Figure 1. Dashboard.

\section{Find the fraction corresponding to the number of the green balls in relation to the sum of the balls:}

a. $\frac{2}{3}$

b. $\frac{15}{6}$

c. $\frac{2}{5}$

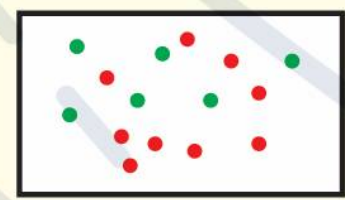

Find the fraction corresponding to the number of the black balls in relation to the sum of the balls:

\section{Way of thinking:}

We count the requested spheres (specifically the black ones here). We count all the spheres (both blue and black spheres].

We wonder what the exercise is asking for. We express the fraction.

Answer: $\frac{7}{14}$

Clarification: The answer $\frac{1}{2}$ could be

correct as both fractions express the same quantity $\left(\frac{7}{14}=\frac{1}{2}\right)$

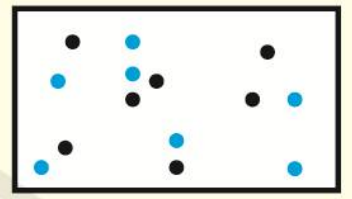

Figure 2. Two sides of a card of the game.

The background consists of random mathematical shapes and equations to embellish the dashboard of the game within a mathematical context. 


\subsubsection{Reliability of Intervention}

The reliability of the intervention will be examined with the help of Cronbach's Alpha. In the table below (Table 4), a total of 25 questions were selected, of which five cognitive areas of the intervention are created.

Table 4. Reliability Statistics.

\begin{tabular}{ccc}
\hline Cronbach's Alpha & Cronbach's Alpha Based on Standardized Items & N of Items \\
\hline 0.766 & 0.771 & 25 \\
\hline
\end{tabular}

The table above shows that the value of Cronbach's Alpha is 0.766, i.e., the level of reliability of all questions is sufficient but not very good. The table below (Table 5) shows all Cronbach's Alpha values if one of the intervention questions is removed each time.

Table 5. Item-Total Statistics.

\begin{tabular}{|c|c|c|c|c|}
\hline & $\begin{array}{l}\text { Scale Mean If } \\
\text { Item Deleted }\end{array}$ & $\begin{array}{l}\text { Scale Variance If } \\
\text { Item Deleted }\end{array}$ & $\begin{array}{c}\text { Corrected Item-Total } \\
\text { Correlation }\end{array}$ & $\begin{array}{l}\text { Cronbach's Alpha } \\
\text { If Item Deleted }\end{array}$ \\
\hline Card-Q1 & 14.91 & 19.326 & 0.017 & 0.775 \\
\hline Card-Q22 & 15.14 & 19.061 & 0.176 & 0.764 \\
\hline Card-Q3 & 14.63 & 19.033 & 0.081 & 0.772 \\
\hline Card-Q4 & 14.58 & 18.072 & 0.327 & 0.756 \\
\hline Card-Q55 & 14.55 & 18.176 & 0.307 & 0.757 \\
\hline Card-Q̂66 & 14.72 & 18.696 & 0.154 & 0.767 \\
\hline Card-Q̄7 & 14.63 & 18.7 & 0.16 & 0.767 \\
\hline Card-Q8 & 14.38 & 18.658 & 0.274 & 0.76 \\
\hline Card-Q99 & 14.48 & 19.15 & 0.074 & 0.77 \\
\hline Card-Q10 & 14.51 & 17.817 & 0.424 & 0.751 \\
\hline Card-Q11 & 14.46 & 17.757 & 0.479 & 0.748 \\
\hline Card-Q12 & 14.47 & 17.874 & 0.432 & 0.751 \\
\hline Card-Q13 & 14.46 & 17.511 & 0.552 & 0.744 \\
\hline Card-Q14 & 14.52 & 17.86 & 0.408 & 0.752 \\
\hline Card-Q15 & 14.66 & 19.356 & 0.003 & 0.776 \\
\hline Card-Q16 & 14.77 & 17.7 & 0.395 & 0.752 \\
\hline Card-Q17 & 14.89 & 17.793 & 0.397 & 0.752 \\
\hline Card-Q18 & 14.39 & 18.254 & 0.402 & 0.754 \\
\hline Card-Q19 & 14.54 & 17.366 & 0.531 & 0.744 \\
\hline Card-Q20 & 14.81 & 17.708 & 0.397 & 0.752 \\
\hline Card-Q21 & 14.75 & 18.161 & 0.282 & 0.759 \\
\hline Card-Q22 & 14.63 & 18.033 & 0.324 & 0.756 \\
\hline Card-Q23 & 14.55 & 18.003 & 0.353 & 0.755 \\
\hline Card-Q24 & 1450 & 18.223 & 0.316 & 0.757 \\
\hline Card-Q25 & 14.77 & 18.106 & 0.296 & 0.758 \\
\hline
\end{tabular}

As is concluded, removing the Card-Q15 slightly improves the value of Cronbach's Alpha, increasing it by just $1 \%$. Nevertheless, this question is part of the intervention, and it is considered good not to remove it. In any case, the improvement that appears from the removal of the Card-Q15 is very small and does not add anything extra to the reliability of the questionnaire.

\subsubsection{Post-Test}

The post-test was carried out 1 month after the teaching by A.A.P. and the collection of the intervention data. All the students retook the test of knowledge about fractions in $45 \mathrm{~min}$, as in the pre-test. It must be mentioned that the pre-test and the post-test are exactly the same tests in order to take reliable results.

\section{Results}

3.1. Performance of Dyslexic Students, Who Were Not Intervened, However, Only Attended the Adapted Analytical Program

Initially, the performance of dyslexic students in both groups, the E.G. and the C.G., is going to be examined. The $t$-test for the equality of two means and the Mann-Whitney 
test in SPSS resulted in exactly the same values, so the $t$-test is going to be used for the analysis of the results. Table 6 shows the mean of dyslexic students in the C.G. and Table 1 in the Appendix A provides the results of the two-sample $t$-test comparing means.

Table 6. Performance of C.G.-A.A.P.

\begin{tabular}{cccccc}
\hline & Knowledge Paper in Fractions & $\mathbf{N}$ & Mean & Std. Deviation & Std. Error Mean \\
\hline \multirow{2}{*}{ Score } & Pre-test & 61 & 6.33 & 2.879 & 0.369 \\
& Post-test & 61 & 8.62 & 2.746 & 0.352 \\
\hline
\end{tabular}

In the conclusion of the $t$-test, dyslexic students appear to be improved after attending the adapted analytical program by 2.29 points.

\subsection{Performance of Dyslexic Students Who Participated in the Intervention}

Regarding the performance of dyslexic students who participated in the intervention, Table 7 below shows that the mean before and after the intervention and Table 2 in the Appendix A provides the results of the two-sample $t$-test comparing means.

Table 7. Performance of E.G.-Intervention Program.

\begin{tabular}{cccccc}
\hline & Knowledge Paper in Fractions & $\mathbf{N}$ & Mean & Std. Deviation & Std. Error Mean \\
\hline \multirow{2}{*}{ Score } & Pre-test & 63 & 6.02 & 5.082 & 0.64 \\
& Post-test & 63 & 11.7 & 4.192 & 0.528 \\
\hline
\end{tabular}

In conclusion, from the two-sample $t$-test comparing means, dyslexic students appear to be significantly better after the intervention by 5.68 points. Examining the results so far, it seems that the intervention has benefited more dyslexic students than the teaching of the adapted analytical program, and in fact this improvement has been interpreted as 1.31 points. In order to confirm the above claim, we will present the comparison of the results of the score in the post-test of the dyslexic students of the two groups: the first group of the dyslexic students in which no intervention was applied (control group) and the second group of the dyslexic students in which the intervention was applied (experimental group). In support of the above claim, a comparison of the post-test score results of the dyslexic students constituting both groups will be presented. As is noticed in Table 8, it seems that the performance of dyslexic students to whom the intervention was applied increased by three points more than the performance of dyslexic students whose teaching was based on the A.A.P. guidelines set by the Greek Ministry of Education. The two-sample $t$-test comparing means is presented in Table 3 in the Appendix A.

Table 8. Comparison C.G.-E.G.

\begin{tabular}{cccccc}
\hline & $\begin{array}{c}\text { Program That the } \\
\text { Students Follow }\end{array}$ & N & Mean & $\begin{array}{c}\text { Std. } \\
\text { Deviation }\end{array}$ & $\begin{array}{c}\text { Std. Error } \\
\text { Mean }\end{array}$ \\
\hline \multirow{2}{*}{ Score } & Adapted Analytical Program & 61 & 8.62 & 2.746 & 0.352 \\
& Interventionprogram & 63 & 11.7 & 4.192 & 0.528 \\
\hline
\end{tabular}

In conclusion, from the $t$-test, the dyslexic students in whom the intervention was applied appear to be more improved than the dyslexic students in whom no intervention was applied. It must be mentioned that this difference is statistically significant.

\subsection{Performance Testing of Dyslexic Students in Each Question, Who Participated in the Intervention}

The analysis of the research data is completed by checking the performance of the dyslexic students in whom the intervention was applied, not in their total score, but in their 
score per question. The results of the two-sample $t$-test comparing means are shown in Tables 4 and 5 in Appendix A. First of all, regarding the first question from the Levene test for the equality of means, it is noticed that the significance of the test is $0<0.05$. Therefore, the null hypothesis is not accepted and the mean values of the two samples are unequal. In conclusion, the intervention enhanced the performance of dyslexic students by 2.11 points when concerned with placing fractions on the line of real numbers. For the second question, in Levene's test for the equality of mean, it is noticed that the significance of the test is $0<$ 0.05. Therefore, the null hypothesis is not accepted and the mean values of the two samples are not equal. So, the intervention enhanced the performance of dyslexic students by 0.33 points as concerned with the equivalence of fractions. The third question concerns finding a fraction between two given fractions. In Levene's test for the equality of means it is noticed that the significance of the test is $0<0.05$. Therefore, the means of the two samples are not equal to each other. So, the intervention enhanced the performance of dyslexic students by 0.42 points, when concerned with finding a fraction between two given fractions. The fourth question concerns the comparison of fractions. In Levene's test for the equality of means, it is noticed that the significance of the test is $0<0.05$. Therefore, the mean values of the two samples are unequal. So, the intervention enhanced the performance of dyslexic students by 0.47 points in comparing fractions. The next question concerns the calculation of the subtraction between two fractions. In Levene's test for the equality of means, it is noticed that the significance of the test is $0.009<0.05$. Therefore, the means of the two samples are not equal to each other. So, the intervention enhanced the performance of dyslexic students by 0.22 points when concerned with calculating the subtraction between two fractions. The next question concerns the multiplication of two fractions. In Levene's test for the equality of means, it is noticed that the significance of the test is $0<0.05$. Therefore, the mean values of the two samples are unequal. So, the intervention enhanced the performance of the dyslexic students by 0.71 points whenconcerned with the multiplication of two fractions. Continuing with the post-test, there was the question of converting a fraction to a decimal number. In Levene's test for the equality of means, it is noticed that the significance of the test is $0<0.05$. Therefore, the mean values of the two samples are unequal. So, the intervention enhanced the performance of dyslexic students by 1.14 points in converting a fraction to a decimal number. Finally, regarding the problem of sharing a sum in four parts based on fractions, in Levene's test for the equality of means, it is noticed that the significance of the test is $0.286>0.05$. Therefore, the means of the two samples are equal to each other. So, the intervention does not seem to have enhanced the performance of dyslexic students when concerned with the problem of dividing a sum into four parts based on fractions.

\section{Discussion}

The exercises carried out during this research were adapted to the needs of dyslexic students. Performing mathematical activities is a complex process that requires the use of many different skills. More specifically, the enhancement in all five learning areas helped each student to develop their mathematical abilities, but also to exhibit further enhancement in the corresponding areas.

The research questions of the study were confirmed, since the performance of student with dyslexia who participated in the intervention project was enhanced in comparison with the control group. In contrast, although the A.A.P. also increased the mean of the performance of dyslexic students, the increase in the mean was less than that of the intervention. The findings of Bryan et al. (1991) confirm how salient it is for dyslexic students to be integrated into special education programs due to significant differences between skills and mathematical performance. The findings of Choi et al. (2016) in this investigation indicated that this approach to inclusive education may benefit all students by improving student academic performance. Within the same context, Tam and Leung (2019) argue that students who showed some benefits in improving their behavioural and cognitive aspects required continuous intervention courses to become self-regulating 
students, develop self-motivation in order to improve, optimize on the learning methods, and adopt strategies in order to achieve academic goals. It should also be mentioned that these results confirm older research findings showing that teaching interventions based on the use of alternative games are more effective than a conventional type of interventions (Shu and Liu 2019; Kim et al. 2017; Fokides 2017; Al-Azawi et al. 2016; Ke and Abras 2012; Kebritchi et al. 2010; Kiger et al. 2012; Kim and Mido 2010; Shin et al. 2011). Additionally, dyslexic students can benefit from the A.A.P., especially if they are adapted in alternative methods of teaching, such as a board game with cards. Yeo et al. (2015) in their research also supported that students made significant improvements across all topics of mathematics through an intervention program. Generally, in the present study it is shown that dyslexic students learn from an educational game, changing their cognitive and affective measurements. This fact is in line with the proposal of Kim et al. (2017), Kraiger et al. (1993) and Castellar et al. (2014) who support that mathematical games can increase mental calculation speed in a similar way as an equivalent number of paper exercises. It is suggested to design games in a way that students' perceived competence, particularly in-game competence, will be increased so that they will be more engaged in game-mediated learning, thus benefiting more from games.

However, in Greece, according to Stampoltzis and Polychronopoulou (2009), research on dyslexia is limited. There is no project that uses an alternative intervention to teach mathematics to dyslexic students of high school ages. Therefore, in the present study, the researcher aims to supplement the existing literature and at the same time shed some light on the effectiveness of an alternative intervention in teaching and learning mathematics for dyslexic students by providing them with different stimuli. This fact, after all, demonstrates the innovation and the importance of the implemented intervention, which if accompanied by the A.A.P. will be of great benefit to the dyslexic students.

Furthermore, using hypothesis testing for the intervention, clear conclusions can be drawn about the design. Firstly, dyslexic students were improved greatly in all the cognitive areas to such a degree that it is considered statistically significant. Secondly, both methods of teaching enhanced the performance of dyslexic students.

Based on the above conclusions, the intervention has positive results in dyslexic students, but this does not mean that modifications are not allowed. Modifications are needed for the techniques used and related to the specific questions in which the dyslexic students did not show much improvement. This fact, however, is not discouraging because there has been not only overall improvement of students, but also improvement in each focused category of the game separately. Therefore, the intervention may be improved in the future only if some corrections are made, for example the sample increases with the number of the participants, changes in the card content of the game which are included in the intervention, and in the method of teaching through the cards. As Papadopoulos (2010) notes in his statistical research, the intervention can be improved by reducing the variability while keeping the sample size constant. However, this is not possible in our case, while the results are collected and analysed exactly as the students gave them. So, a practical solution would be to increase the sample size. In this way, the variability will be reduced. Furthermore, Sabri and Gyateng (2015) state that the chance of detecting a strong statistical difference will be increased by picking a large enough sample size. In conclusion, it is worth noting the difficulties and limitations of the research. Initially, collecting the sample was not easy because many school principals presented concerns about the time and the day that the students were going to participate and thus disagreed with the research process. In addition, some students wanted to leave the class because they felt tired or anxious about their performance, even though they knew in advance that the process was anonymous and their performance would not be graded. Another shortcoming was the fact that, many students with dyslexia needed more time to complete the pre- and post-test. Finally, increasing the sample, adding new cards, or modifying the existing ones in the board game may lead to safer conclusions. This fact is relayed to the improvement of the value of Cronbach's Alpha in case of the removal of one card. 


\section{Conclusions}

The first general conclusion is that the alternative intervention motivated the dyslexic students to work on their performance and show considerable signs of improvement to such a degree that it is considered statistically significant. In light of this, differentiated teaching of dyslexic students is helpful for them to understand the mathematical concept of fractions. This is precisely the reason why dyslexic students, who did not participate in the alternative intervention, also seem to be improved, presenting a slightly lower mean than that of the group of dyslexic students who attended the proposed intervention. The second conclusion is that dyslexic students can also benefit from the A.A.P., especially if they are adapted to alternative methods of teaching, such as a board game with cards. The third conclusion, regarding the duration of the intervention, is that more time and more sessions with students are needed. There were many students who left the project because of the time and the anxiety they felt. The fourth and last conclusion is that the alternative intervention can be further modified. A practical solution would be to modify some of the techniques that were used and related to the specific questions, in which the dyslexic students did not show much improvement in their performance. Further research on a larger sample and with small changes in the intervention, making it even more dynamic, can possibly bring more reliable conclusions concerning the contribution of differentiated teaching to dyslexic learners. These conclusions show that dyslexic students could have a better performance in other countries too under a similar teaching method.

Author Contributions: Conceptualization, E.M., N.J.-F. and V.M.-D.; methodology, E.M. and N.J.-F. and V.M.-D.; validation, E.M., N.J.-F. and V.M.-D.; formal analysis, E.M.; investigation, E.M. and N.J.-F.; resources, E.M.; data curation, E.M., N.J.-F. and V.M.-D.; writing-original draft preparation, E.M., N.J.-F. and V.M.-D.; writing-review and editing, E.M., N.J-F. and V.M.-D.; supervision, N.J.-F. and V.M.-D. All authors have read and agreed to the published version of the manuscript.

Funding: This research received no external funding.

Institutional Review Board Statement: Not applicable.

Informed Consent Statement: Not applicable.

Data Availability Statement: Not applicable.

Conflicts of Interest: The authors declare no conflict of interest.

\section{Appendix A}

Table 1. Independent Samples of C.G.-A.A.P.

\begin{tabular}{|c|c|c|c|c|c|c|c|c|c|c|}
\hline & & \multicolumn{2}{|c|}{$\begin{array}{c}\text { Levene's Test for Equality } \\
\text { of Variances }\end{array}$} & \multicolumn{7}{|c|}{$t$-Test for Equality of Means } \\
\hline & & \multirow[t]{2}{*}{$\mathbf{F}$} & \multirow[t]{2}{*}{ Sig. } & \multirow[t]{2}{*}{$\mathbf{t}$} & \multirow[t]{2}{*}{ df } & \multirow{2}{*}{$\begin{array}{l}\text { Sig. } \\
\text { (2-Tailed) }\end{array}$} & \multirow{2}{*}{$\begin{array}{c}\text { Mean } \\
\text { Difference }\end{array}$} & \multirow{2}{*}{$\begin{array}{l}\text { Std. Error } \\
\text { Difference }\end{array}$} & \multicolumn{2}{|c|}{$\begin{array}{l}\text { 95\% Confidence Interva } \\
\text { of the Difference }\end{array}$} \\
\hline & & & & & & & & & Lower & Upper \\
\hline \multirow[t]{2}{*}{ Score } & $\begin{array}{l}\text { Equal variances } \\
\text { assumed }\end{array}$ & 0.214 & 0.645 & -4.505 & 120 & 0 & -2.295 & 0.509 & -3.304 & -1.286 \\
\hline & $\begin{array}{l}\text { Equal variances not } \\
\text { assumed }\end{array}$ & & & -4.505 & 119.73 & 0 & -2.295 & 0.509 & -3.304 & -1.286 \\
\hline
\end{tabular}

(C.G. refers to Control Group and A.A.P. refers to Adapted Analytical Programs). 
Table 2. Independent Samples Test for E.G.-Intervention Program.

\begin{tabular}{|c|c|c|c|c|c|c|c|c|c|c|}
\hline & & \multicolumn{2}{|c|}{$\begin{array}{c}\text { Levene's Test for Equality } \\
\text { of Variances }\end{array}$} & \multicolumn{7}{|c|}{$t$-Test for Equality of Means } \\
\hline & & \multirow{2}{*}{ F } & \multirow[t]{2}{*}{ Sig. } & \multirow{2}{*}{$t$} & \multirow{2}{*}{ df } & \multirow{2}{*}{$\begin{array}{c}\text { Sig. } \\
\text { (2-Tailed) }\end{array}$} & \multirow{2}{*}{$\begin{array}{c}\text { Mean } \\
\text { Difference }\end{array}$} & \multirow{2}{*}{$\begin{array}{l}\text { Std. Error } \\
\text { Difference }\end{array}$} & \multicolumn{2}{|c|}{$\begin{array}{l}95 \% \text { Confidence Interval } \\
\text { of the Difference }\end{array}$} \\
\hline & & & & & & & & & Lower & Upper \\
\hline \multirow[t]{2}{*}{ Score } & $\begin{array}{l}\text { Equal variances } \\
\text { assumed }\end{array}$ & 0.653 & 0.421 & -6.847 & 124 & 0.000 & -5.683 & 0.830 & -7.325 & -4.040 \\
\hline & $\begin{array}{l}\text { Equal variances not } \\
\text { assumed }\end{array}$ & & & -6.847 & 119.670 & 0.000 & -5.683 & 0.830 & -7.326 & -4.039 \\
\hline
\end{tabular}

(E.G. refers to Experimental Group).

Table 3. Independent Samples Test comparison of C.G. and E.G.

\begin{tabular}{|c|c|c|c|c|c|c|c|c|c|c|}
\hline & & \multicolumn{2}{|c|}{$\begin{array}{c}\text { Levene's Test for Equality } \\
\text { of Variances }\end{array}$} & \multicolumn{7}{|c|}{$t$-Test for Equality of Means } \\
\hline & & \multirow[t]{2}{*}{$\mathbf{F}$} & \multirow[t]{2}{*}{ Sig. } & \multirow[t]{2}{*}{$\mathbf{t}$} & \multirow[t]{2}{*}{ df } & \multirow{2}{*}{$\begin{array}{l}\text { Sig. } \\
\text { (2-Tailed) }\end{array}$} & \multirow{2}{*}{$\begin{array}{c}\text { Mean } \\
\text { Difference }\end{array}$} & \multirow{2}{*}{$\begin{array}{l}\text { Std. Error } \\
\text { Difference }\end{array}$} & \multicolumn{2}{|c|}{$\begin{array}{l}95 \% \text { Confidence Interval } \\
\text { of the Difference }\end{array}$} \\
\hline & & & & & & & & & Lower & Upper \\
\hline \multirow[t]{2}{*}{ Score } & $\begin{array}{l}\text { Equal variances } \\
\text { assumed }\end{array}$ & 19.571 & 0.000 & -4.816 & 122 & 0.000 & -3.075 & 0.639 & -4.339 & -1.811 \\
\hline & $\begin{array}{l}\text { Equal variances not } \\
\text { assumed }\end{array}$ & & & -4.848 & 107.345 & 0.000 & -3.075 & 0.634 & -4.333 & -1.818 \\
\hline
\end{tabular}

Table 4. Performance testing of dyslexic students in each question who participated in the intervention.

\begin{tabular}{|c|c|c|c|c|c|}
\hline & $\begin{array}{l}\text { Knowledge Paper } \\
\text { in Fractions }\end{array}$ & $\mathbf{N}$ & Mean & $\begin{array}{l}\text { Std. } \\
\text { Deviation }\end{array}$ & $\begin{array}{l}\text { Std. Error } \\
\text { Mean }\end{array}$ \\
\hline \multirow{2}{*}{$\begin{array}{l}\text { Note in the following number line the points corresponding } \\
\text { to the given fractions } 2 / 7,7 / 7,8 / 7,5 / 7,0,1 / 7,15 / 7\end{array}$} & Pre-test & 63 & 2.52 & 2.687 & 0.339 \\
\hline & Post-test & 63 & 4.63 & 2.465 & 0.311 \\
\hline \multirow{2}{*}{$\begin{array}{l}\text { We have the fractions } 4 / 9 \text { and } 16 / 19 . \text { Are these fractions } \\
\text { equivalent? Justify your answer. }\end{array}$} & Pre-test & 63 & 0.32 & 0.469 & 0.059 \\
\hline & Post-test & 63 & 0.65 & 0.481 & 0.061 \\
\hline \multirow{2}{*}{ Find a fraction between $3 / 4$ and $5 / 6$} & Pre-test & 63 & 0.11 & 0.317 & 0.040 \\
\hline & Post-test & 63 & 0.54 & 0.502 & 0.063 \\
\hline \multirow{2}{*}{ Compare these fractions: $5 / 8$ and $4 / 6$. } & Pre-test & 63 & 0.24 & 0.429 & 0.054 \\
\hline & Post-test & 63 & 0.71 & 0.455 & 0.057 \\
\hline \multirow{2}{*}{ Circle the correct answer for this operation $6 / 7-4 / 21$} & Pre-test & 63 & 0.52 & 0.503 & 0.063 \\
\hline & Post-test & 63 & 0.75 & 0.439 & 0.055 \\
\hline \multirow{2}{*}{ Calculate the operations $3 / 4^{*} 5 / 3$ and $4 / 3^{*} 15 / 8$} & Pre-test & 63 & 0.95 & 0.923 & 0.116 \\
\hline & Post-test & 63 & 1.67 & 0.672 & 0.085 \\
\hline \multirow{2}{*}{$\begin{array}{l}\text { Convert the following fractions to decimal numbers: } \\
\qquad 7 / 10,9 / 25,4 / 50\end{array}$} & Pre-test & 63 & 0.67 & 0.967 & 0.122 \\
\hline & Post-test & 63 & 1.81 & 1.045 & 0.132 \\
\hline \multirow{2}{*}{ Four people money sharing problem } & Pre-test & 63 & 0.68 & 1.280 & 0.161 \\
\hline & Post-test & 63 & 0.94 & 1.378 & 0.174 \\
\hline
\end{tabular}


Table 5. Independent Samples Test.

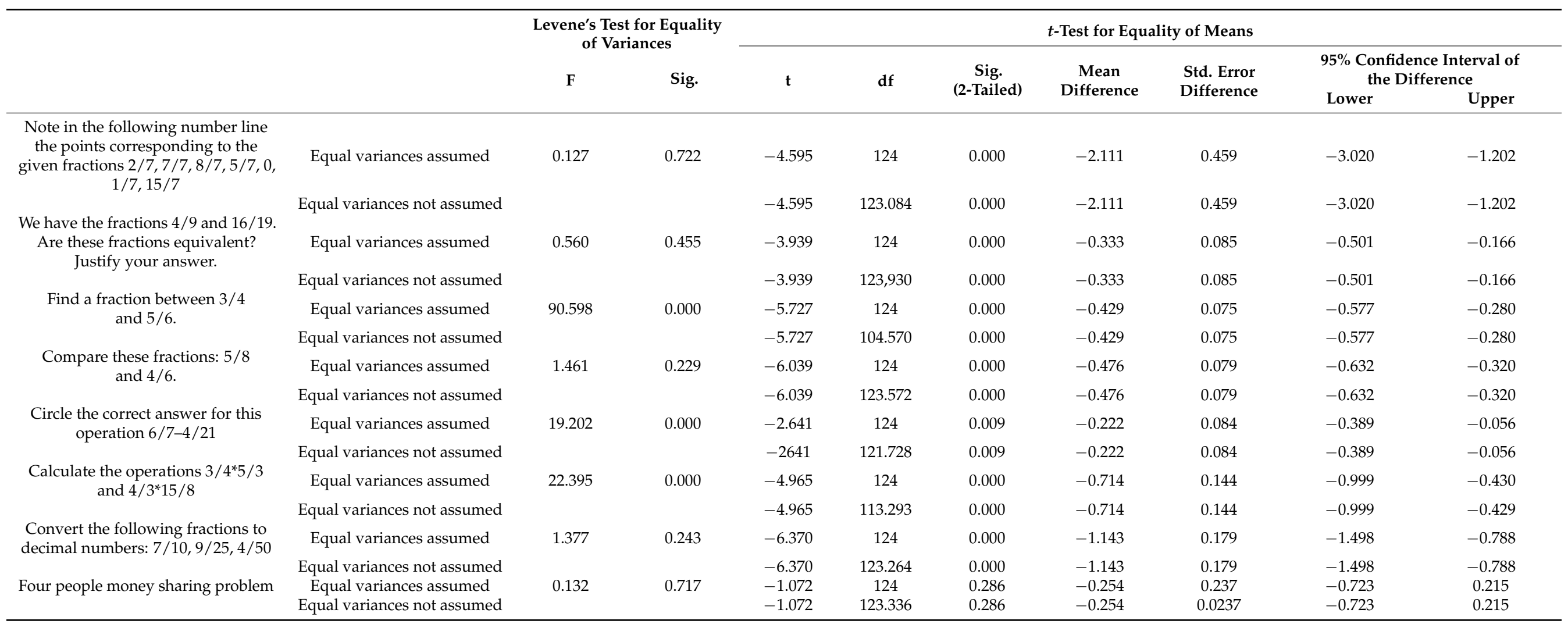




\section{References}

Abd Rauf, Athira Amira, Maizatul Akmar Ismail, Vimala Balakrishnan, and Khalid Haruna. 2018. Dyslexic Children: The Need for Parents Awareness. Journal of Education and Human Development 7: 91-99. [CrossRef]

Abd Rauf, Athira Amira, Maizatul Akmar Ismail, Vimala Balakrishnan, Loh Sau Cheong, Novia Indriaty Admodisastro, and Khalid Haruna. 2020. Analysis of Support for Parents in Raising Children with Dyslexia. Journal of Family Issues 42: 276-92. [CrossRef]

Al-Azawi, Rula, Fatma Al-Faliti, and Mazin Al-Blushi. 2016. Educational Gamification vs. Game Based Learning: Comparative Study. International Journal of Innovation, Management and Technology 7: 131-36. [CrossRef]

Bryan, T., M. Bay, N. Lopez-Reyna, and M. Donahue. 1991. Characteristics of students with learning disabilities: A summary of the extant data base and its implications for educational programs. In The Regular Edu Cation Initiative: Alternative Perspectives. Edited by John Wills Lloyd, Nirbhay N. Singh and Alan C. Repp. Sycamore: Thomson Brooks/Cole, pp. 121-31.

Bryant, Brian R., Diane Pedrotty Bryant, Jennifer Porterfield, Minyi Shih Dennis, Terry Falcomata, Courtney Valentine, Chelsea Brewer, and Kathy Bell. 2014. The Effects of a Tier 3 Intervention on the Mathematics Performance of Second Grade Students with Severe Mathematics Difficulties. Journal of Learning Disabilities 49: 176-88. [CrossRef] [PubMed]

Castellar, Elena Núñez, Jan Van Looy, Arnaud Szmalec, and Lieven de Marez. 2014. Improving Arithmetic Skills through Gameplay: Assessment of the Effectiveness of an Educational Game in Terms of Cognitive and Affective Learning Outcomes. Information Sciences 264: 19-31. [CrossRef]

Choi, Jeong Hoon, Jessica M. Meisenheimer, Amy B. McCart, and Wayne Sailor. 2016. Improving Learning for All Students through Equity-Based Inclusive Reform Practices. Remedial and Special Education 38: 28-41. [CrossRef]

Cook, Sara Cothren, Lauren W. Collins, Lisa L. Morin, and Paul J. Riccomini. 2019. Schema-Based Instruction for Mathematical Word Problem Solving: An Evidence-Based Review for Students with Learning Disabilities. Learning Disability Quarterly 43: 75-87. [CrossRef]

Emerson, Jane. 2015. The enigma of dyscalculia. In The Routledge International Handbook of Dyscalculia and Mathematical Learning Difficulties. London: Routledge, pp. 217-27.

Fokides, Emmanuel. 2017. Digital Educational Games and Mathematics. Results of a Case Study in Primary School Settings. Education and Information Technologies 23: 851-67. [CrossRef]

Futterman, Kathy, and Kathryn R. Futterman. 2017. Identification of Students with Dyslexia in California Public Schools. Ph.D. thesis, California Public Schools, Coal Center, PA, USA.

Grehan, Martin, Ciarán Mac an Bhaird, and Ann O'Shea. 2015. Investigating Students' Levels of Engagement with Mathematics: Critical Events, Motivations, and Influences on Behaviour. International Journal of Mathematical Education in Science and Technology 47: 1-28. [CrossRef]

Huang, Yanhong, Chongtao Xu, Meirong He, Wenlong Huang, and Kusheng Wu. 2020a. Saliva Cortisol, Melatonin Levels and Circadian Rhythm Alterations in Chinese Primary School Children with Dyslexia. Medicine 99: e19098. [CrossRef] [PubMed]

Huang, Yanhong, Meirong He, Anna Li, Yuhang Lin, Xuanzhi Zhang, and Kusheng Wu. 2020b. Personality, Behavior Characteristics, and Life Quality Impact of Children with Dyslexia. International Journal of Environmental Research and Public Health 17: 1415. [CrossRef]

Ke, Fengfeng, and Tatiana Abras. 2012. Games for Engaged Learning of Middle School Children with Special Learning Needs. British Journal of Educational Technology 44: 225-42. [CrossRef]

Kebritchi, Mansureh, Atsusi Hirumi, and Haiyan Bai. 2010. The Effects of Modern Mathematics Computer Games on Mathematics Achievement and Class Motivation. Computers \& Education 55: 427-43. [CrossRef]

Kiger, Derick, Dani Herro, and Deb Prunty. 2012. Examining the Influence of a Mobile Learning Intervention on Third Grade Math Achievement. Journal of Research on Technology in Education 45: 61-82. [CrossRef]

Kim, Sunha, and Chang Mido. 2010. Computer games for the math achievement of diverse students. Journal of Educational Technology $\mathcal{E}$ Society 13: 224-32.

Kim, Sunha, Mido Chang, Kirby Deater-Deckard, Michael A. Evans, Anderson Norton, and Yavuz Samur. 2017. Educational Games and Students' Game Engagement in Elementary School Classrooms. Journal of Computers in Education 4: 395-418. [CrossRef]

Kraiger, Kurt, J. Kevin Ford, and Eduardo Salas. 1993. Application of Cognitive, Skill-Based, and Affective Theories of Learning Outcomes to New Methods of Training Evaluation. Journal of Applied Psychology 78: 311-28. [CrossRef]

López-Hernández, Danilo, Michel Brossard, Jean-Claude Fardeau, and Michel Lepage. 2005. Effect of Different Termite Feeding Groups on P Sorption and P Availability in African and South American Savannas. Biology and Fertility of Soils 42: 207-14. [CrossRef]

Macrae, Sheila, Margaret Brown, Hannah Bartholomew, and Melissa Rodd. 2003. An Examination of One Group of Failing Single Honours Students in One University. MSOR Connections 3: 17-20. [CrossRef]

Muhamad, Hani Zohra, Zachary Walker, and Kara Rosenblatt. 2016. The Teaching of Maths to Students with Dyslexia: A Teachers' Perspective. Asia Pacific Journal of Developmental Differences 3: 228-47. [CrossRef]

Papadimitriou, Panagiotis, and Sotiria Tzivinikou. 2019. Departments of Integration in Secondary Education: A Critical Review on Procedure and the Educational Practices of the Evaluation and the Intervention that Are Adopted. Panhellenic Conference of Educational Sciences 9: 565-78. [CrossRef] 
Papadopoulos, Georgios. 2010. Laboratory of Mathematics \& Statistics [Course Notes]. Available online: www.aua.gr.http://www. aua.gr/gpapadopoulos/shmeiwseis.php (accessed on 30 September 2010).

Robinson, Deborah. 2017. Effective Inclusive Teacher Education for Special Educational Needs and Disabilities: Some More Thoughts on the Way Forward. Teaching and Teacher Education 61: 164-78. [CrossRef]

Roitsch, Jane, and Silvana Watson. 2019. An Overview of Dyslexia: Definition, Characteristics, Assessment, Identification, and Intervention. Science Journal of Education 7: 81. [CrossRef]

Rüsseler, Jascha, Zheng Ye, Ivonne Gerth, Gregor R. Szycik, and Thomas F. Münte. 2017. Audio-Visual Speech Perception in Adult Readers with Dyslexia: An FMRI Study. Brain Imaging and Behavior 12: 357-68. [CrossRef]

Sabri, Farooq, and Tracey Gyateng. 2015. Understanding Statistical Significance: A Short Guide. London: New Philanthropy Capital.

Shin, Mikyung, and Diane P. Bryant. 2016. Improving the Fraction Word Problem Solving of Students with Mathematics Learning Disabilities. Remedial and Special Education 38: 76-86. [CrossRef]

Shin, Namsoo, LeeAnn M. Sutherland, Cathleen A. Norris, and Elliot Soloway. 2011. Effects of Game Technology on Elementary Student Learning in Mathematics. British Journal of Educational Technology 43: 540-60. [CrossRef]

Shu, Liuyi, and Min Liu. 2019. Student engagement in game-based learning: A literature review from 2008 to 2018. Journal of Educational Multimedia and Hypermedia 28: 193-215.

Stampoltzis, Aglaia, and Stavroula Polychronopoulou. 2009. Greek University Students with Dyslexia: An Interview Study. European Journal of Special Needs Education 24: 307-21. [CrossRef]

Tam, Irelan O. L., and Cynthia Leung. 2019. Evaluation of the Effectiveness of a Literacy Intervention Programme on Enhancing Learning Outcomes for Secondary Students with Dyslexia in Hong Kong. Dyslexia 25: 296-317. [CrossRef]

Witzel, Bradley, and Minnie Mize. 2018. Meeting the Needs of Students with Dyslexia and Dyscalculia. SRATE Journal 27: 31-39.

Yeo, Rebecca, Tim Bunn, Aishah Abdullah, Siti Aisha Bte Shukri, and Anaberta Oehlers-Jaen. 2015. Evaluating the Progress of Dyslexic Children on a Small-Group Maths Intervention Programme. Asia Pacific Journal of Developmental Differences 2: 144-57. [CrossRef] 

MDPI

St. Alban-Anlage 66 4052 Basel

Switzerland

Tel. +41 616837734

Fax +41 613028918

www.mdpi.com

Social Sciences Editorial Office

E-mail: socsci@mdpi.com

www.mdpi.com/journal/socsci

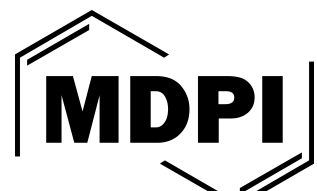



MDPI

St. Alban-Anlage 66

4052 Basel

Switzerland

Tel: +41 616837734

Fax: +41 613028918

www.mdpi.com 